Prepared in cooperation with the Illinois River Watershed Partnership

\title{
Effects of Land Use, Stream Habitat, and Water Quality on Biological Communities of Wadeable Streams in the Illinois River Basin of Arkansas, 2011 and 2012
}

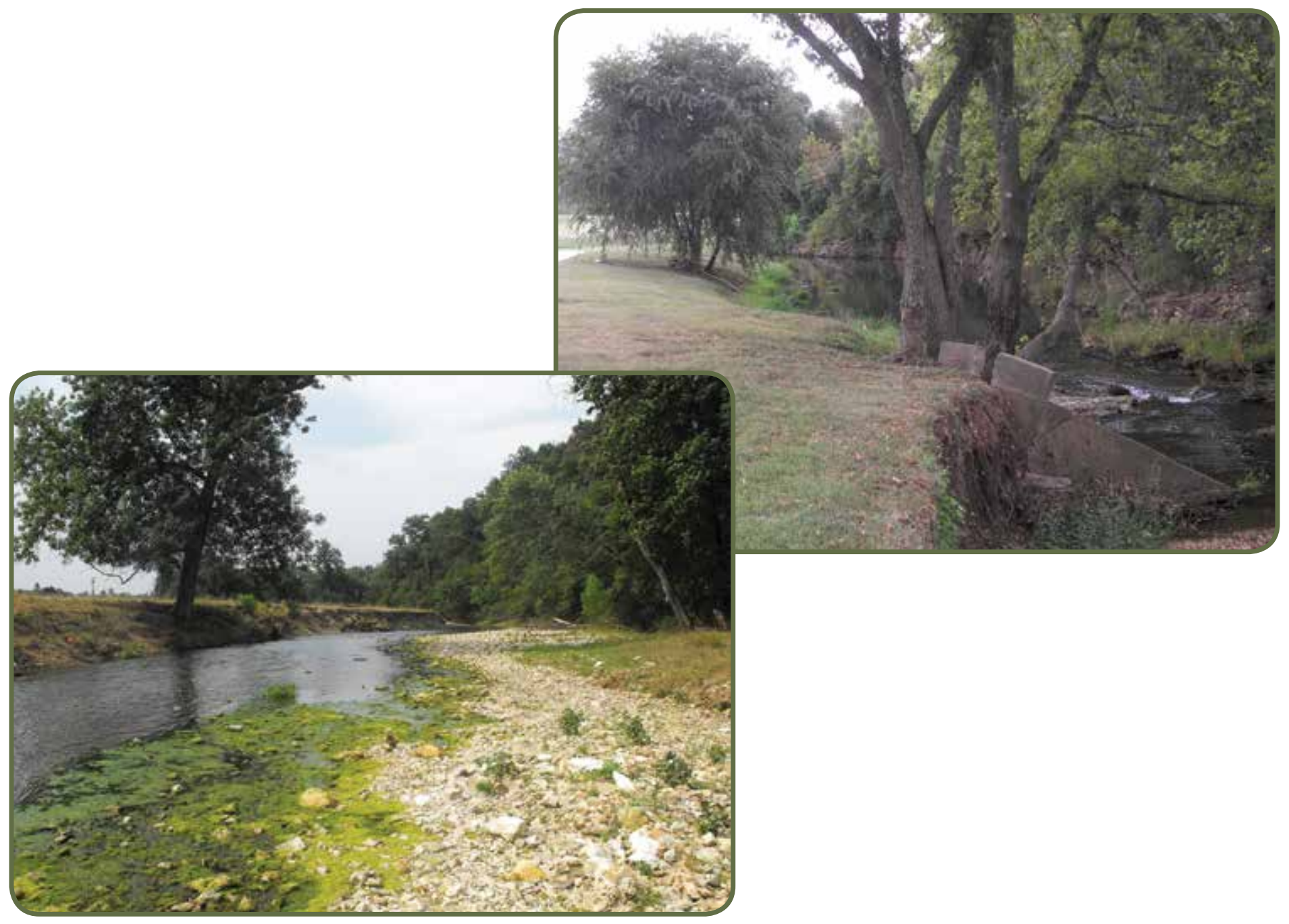

Scientific Investigations Report 2014-5009 


\section{Cover:}

Top, Section of Osage Creek in an urban area upstream from a wastewater-treatment plant.

Bottom, Section of Osage Creek in an agriculture area downstream from a wastewater-treatment plant. 


\section{Effects of Land Use, Stream Habitat, and Water Quality on Biological Communities of Wadeable Streams in the Illinois River Basin of Arkansas, 2011 and 2012}

By James C. Petersen, B.G. Justus, and Bradley J. Meredith

Prepared in cooperation with the Illinois River Watershed Partnership

Scientific Investigations Report 2014-5009 


\section{U.S. Department of the Interior \\ SALLY JEWELL, Secretary}

\section{U.S. Geological Survey \\ Suzette M. Kimball, Acting Director}

\section{U.S. Geological Survey, Reston, Virginia: 2014}

For more information on the USGS — the Federal source for science about the Earth, its natural and living resources, natural hazards, and the environment, visit http://www.usgs.gov or call 1-888-ASK-USGS.

For an overview of USGS information products, including maps, imagery, and publications, visit http://www.usgs.gov/pubprod

To order this and other USGS information products, visit http://store.usgs.gov

Any use of trade, firm, or product names is for descriptive purposes only and does not imply endorsement by the U.S. Government.

Although this information product, for the most part, is in the public domain, it also may contain copyrighted materials as noted in the text. Permission to reproduce copyrighted items must be secured from the copyright owner.

Suggested citation:

Petersen, J.C., Justus, B.G., and Meredith, B.J, 2014, Effects of land use, stream habitat, and water quality on biological communities of wadeable streams in the Illinois River Basin of Arkansas, 2011 and 2012: U.S. Geological Survey Scientific Investigations Report 2014-5009, 89 p., http://dx.doi.org/10.3133/sir20145009.

ISSN 2328-0328 (online) 


\section{Acknowledgments}

This report was prepared in cooperation with the Illinois River Watershed Partnership (IRWP). The funding for activities that included the biological and water-quality sampling and report preparation was obtained by the IRWP through the Arkansas Natural Resources Commission (ANRC) as a "319 grant" from the U.S. Environmental Protection Agency. The assistance of IRWP Executive Director Dr. Delia Haak, the IRWP Board of Directors, and ANRC Grants Manager Tony Ramick is gratefully acknowledged. Thomas Cuffney and Amanda Bell with the U.S. Geological Survey provided assistance with processing of the macroinvertebrate and periphyton data. 



\section{Contents}

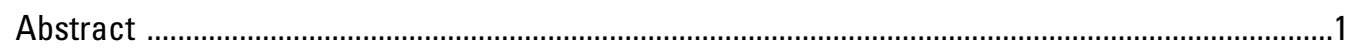

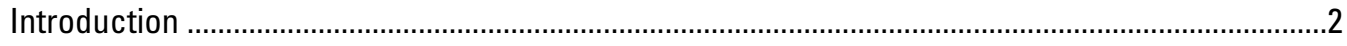

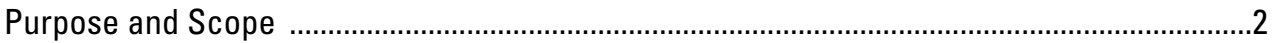

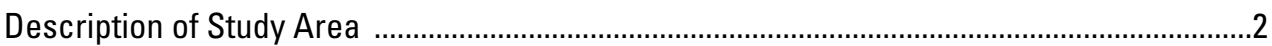

Weather Conditions During the Sampling Periods ....................................................................5

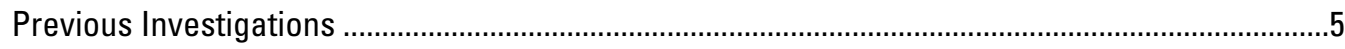

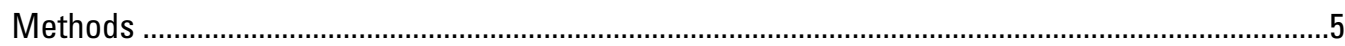

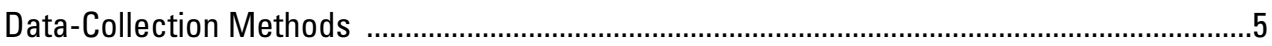

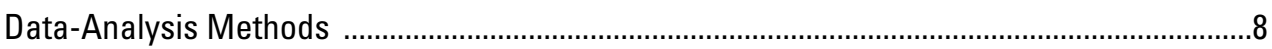

Classes of Environmental Factors Affecting Biological Communities ..............................................9

Land-Use Factors Associated With Stream Basins .............................................................

Habitat Factors Associated With Stream Reaches .................................................................11

Water-Quality Factors Associated With Stream Reaches ........................................................13

Description of Biological Communities and Relations to Land Use, Stream Habitat, and

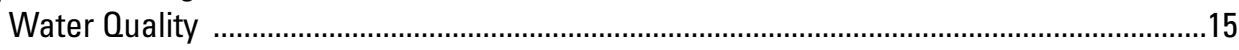

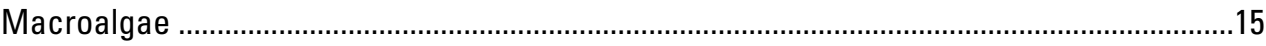

Periphyton Communities ......................................................................................................17

Relations Between Periphyton Communities and Land Use, Stream Habitat, and Water-Quality Factors ........................................................................................ 18

Macroinvertebrate Communities ...........................................................................................2

Relations Between Macroinvertebrate Communities and Land Use, Stream Habitat,

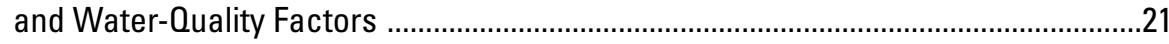

Combined-Gradient Sites ...................................................................................................21

Relations Between Selected Macroinvertebrate Metrics and Percent

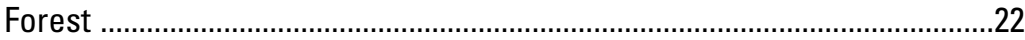

Relations Between the Macroinvertebrate Index and Selected Environmental Factors ..............................................................................24

Agriculture Gradient Sites ......................................................................................24

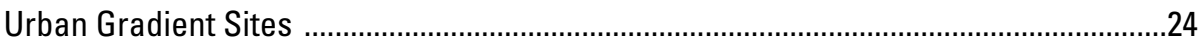

Wastewater-Treatment Plant Sites .............................................................................26

Fish Communities .............................................................................................................26

Relations Between Fish Communities and Land Use, Stream Habitat, And Water-

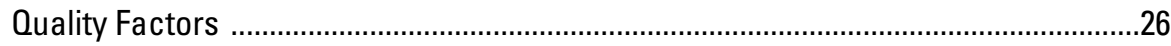

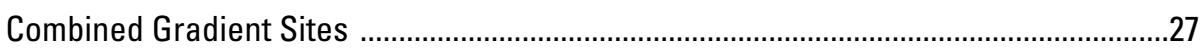

Relations Between Fish Index of Biotic Integrity, Selected Fish Metrics, and Percent Forest ..........................................................................................27

Relations Between the Fish Index and Selected Environmental Factors ..............29

Agriculture Gradient Sites ........................................................................................29

Urban Gradient Sites ...................................................................................................29

Wastewater-Treatment Plant Sites ....................................................................................

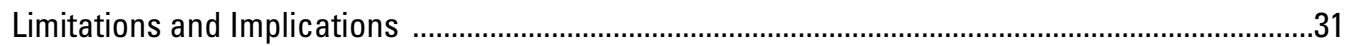

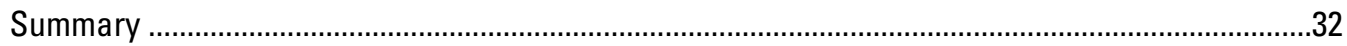

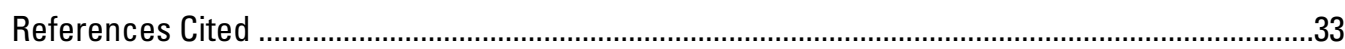




\section{Figures}

1. Illinois River Basin study area and sampling sites ...

2. Graph showing land-use variation among sites along land-use gradients in the Illinois River Basin study area

3. Scatterplots showing relation between macroalgae percent cover and selected environmental factors in the Illinois River Basin study area .

4. Scatterplots showing relations between periphyton metrics and percent forest in the Illinois River Basin study area

5. Scatterplots showing relations between periphyton total biovolume and selected environmental factors in the Illinois River Basin study area

6. Scatterplots showing relations between percent forest, the macroinvertebrate index, and selected macroinvertebrate metrics in the Illinois River Basin study area

7. Scatterplots showing relations between the macroinvertebrate index and selected environmental factors in the Illinois River Basin study area

8. Scatterplots showing relations between percent forest in basin and the Ozark Highlands fish index of biotic integrity and selected fish metrics in the Illinois River Basin study area

9. Relations between the Ozark Highlands fish index of biotic integrity and selected environmental factors in the Illinois River Basin study area

\section{Tables}

1. List of sampling sites and related information for the Illinois River Basin study area

2. List of environmental factors compared to biological metrics and indices . .4

3. Relative percent differences between primary and duplicate water-quality samples collected in 2011 and 2012 in the Illinois River Basin study area

4. Land-use percentages, poultry house density, and road density associated with sampling sites in the Illinois River Basin study area

5. Correlations between land-use percentages and selected environmental factors in the Illinois River Basin study area

6. Habitat factor values associated with sampling sites in the Illinois River Basin study area

7. Water-quality data associated with sampling sites in the Illinois River Basin study area

8. Macroalgae percent cover and values for selected environmental factors for sampling sites in the Illinois River Basin study area

9. Correlations between macroalgae percent cover and selected environmental factors in the Illinois River Basin study area

10. List of algal taxa and biovolumes for sampling sites in the Illinois River Basin study area

11. Periphyton metric values at sampling sites in the Illinois River Basin study area .........47

12. Correlations between periphyton metrics and selected environmental factors in the Illinois River Basin study area 
13. List of macroinvertebrate taxa and relative abundances for sampling sites in the Illinois River Basin study area

14. Macroinvertebrate metric and index scores for sampling sites in the Illinois River Basin study area

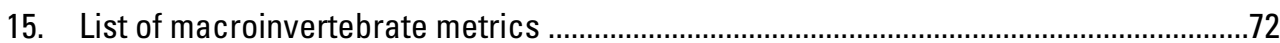

16. Correlations between macroinvertebrate metrics and index and selected environmental factors for sites not affected by wastewater-treatment plants

17. Correlations between macroinvertebrate metrics and index and environmental factors at agriculture gradient sites in the Illinois River Basin study area

18. Correlations between macroinvertebrate metrics and index and selected environmental factors at urban gradient sites in the Illinois River Basin study area

19. Fish relative abundance and taxa richness for the sampling sites in the Illinois

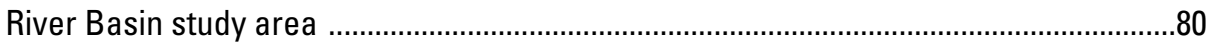

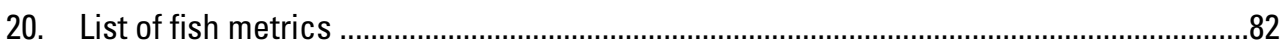

21. Fish metric and index of biotic integrity values for sampling sites in the Illinois River Basin study area

22. Correlations between fish metrics and Ozark Highlands fish index of biotic integrity and selected environmental factors for sites not affected by wastewater-treatment plants in the Illinois River Basin study area

23. Correlation between fish metrics and Ozark Highlands fish index of biotic integrity and selected environmental factors at agriculture gradient sites in the Illinois River Basin study area

24. Correlation between fish metrics and Ozark Highlands fish index of biotic integrity and selected environmental factors at urban gradient sites in the Illinois River Basin study area 


\section{Conversion Factors}

Inch/Pound to SI

\begin{tabular}{|c|c|c|}
\hline Multiply & By & To obtain \\
\hline \multicolumn{3}{|c|}{ Length } \\
\hline inch (in.) & 2.54 & centimeter $(\mathrm{cm})$ \\
\hline inch (in.) & 25.4 & millimeter (mm) \\
\hline foot $(\mathrm{ft})$ & 0.3048 & meter $(\mathrm{m})$ \\
\hline mile (mi) & 1.609 & kilometer $(\mathrm{km})$ \\
\hline \multicolumn{3}{|c|}{ Area } \\
\hline square foot $\left(\mathrm{ft}^{2}\right)$ & 0.09290 & square meter $\left(\mathrm{m}^{2}\right)$ \\
\hline square mile $\left(\mathrm{mi}^{2}\right)$ & 259.0 & hectare (ha) \\
\hline square mile $\left(\mathrm{mi}^{2}\right)$ & 2.590 & square kilometer $\left(\mathrm{km}^{2}\right)$ \\
\hline \multicolumn{3}{|c|}{ Volume } \\
\hline cubic inch $\left(\mathrm{in}^{3}\right)$ & 16.39 & cubic centimeter $\left(\mathrm{cm}^{3}\right)$ \\
\hline \multicolumn{3}{|c|}{ Flow rate } \\
\hline cubic foot per second $\left(\mathrm{ft}^{3} / \mathrm{s}\right)$ & 0.02832 & cubic meter per second $\left(\mathrm{m}^{3} / \mathrm{s}\right)$ \\
\hline
\end{tabular}

Temperature in degrees Celsius $\left({ }^{\circ} \mathrm{C}\right)$ may be converted to degrees Fahrenheit $\left({ }^{\circ} \mathrm{F}\right)$ as follows:

${ }^{\circ} \mathrm{F}=\left(1.8 \times^{\circ} \mathrm{C}\right)+32$

Temperature in degrees Fahrenheit $\left({ }^{\circ} \mathrm{F}\right)$ may be converted to degrees Celsius $\left({ }^{\circ} \mathrm{C}\right)$ as follows:

${ }^{\circ} \mathrm{C}=\left({ }^{\circ} \mathrm{F}-32\right) / 1.8$

Horizontal coordinate information is referenced to the North American Datum of 1983 (NAD83).

Specific conductance is given in microsiemens per centimeter at 25 degrees Celsius $(\mu \mathrm{S} / \mathrm{cm}$ at $\left.25^{\circ} \mathrm{C}\right)$.

Concentrations of chemical constituents in water are given in milligrams per liter (mg/L). 


\title{
Effects of Land Use, Stream Habitat, and Water Quality on Biological Communities of Wadeable Streams in the Illinois River Basin of Arkansas, 2011 and 2012
}

\author{
By James C. Petersen, B.G. Justus, and Bradley J. Meredith
}

\section{Abstract}

The Illinois River Basin includes an area of diverse land use in northwestern Arkansas. Land-use data collected in 2006 indicate that most of the land in the basin is agricultural. The agricultural land is used primarily for production of poultry and cattle.

Eighteen sites were selected from the list of candidate sites based on drainage area, land use, presence or absence of an upstream wastewater-treatment plant, water quality, and other information gathered during the reconnaissance. An important consideration in the process was to select sites along gradients of forest to urban land use and forest to agricultural land use. Water-quality samples were collected for analysis of nutrients, and a multiparameter field meter was used to measure water temperature, specific conductance, $\mathrm{pH}$, and dissolved oxygen. Streamflow was measured immediately following the water-quality sampling. Macroalgae coverage was estimated and periphyton, macroinvertebrate, and fish communities were sampled at each site. Stream habitat also was assessed.

Many types of land-use, water-quality, and habitat factors affected one or more aspects of the biological communities. Several macroinvertebrate and fish metrics changed in response to changes in percent forest; sites that would be considered most disturbed, based on these metrics, are sites with the highest percentages of urban land use in their associated basins.

The presence of large mats of macroalgae was one of the most noticeable biological characteristics in several streams within the Illinois River Basin. The highest macroalgae percent cover values were recorded at four sites downstream from wastewater-treatment plants. Macroalgae percent cover was strongly correlated only with bed substrate size, canopy closure, and specific conductance.

Periphyton metrics were most often and most strongly correlated with riparian shading, specific conductance, substrate turbidity, percent agriculture, poultry house density, and unpaved road density; some of these factors were strongly correlated with percent forest, percent urban, or percent agriculture. Total biovolume of periphyton was not strongly correlated with any of the land use, habitat, or water-quality factors assessed in the present study. Although algal growth typically increases with higher nutrient concentrations and less shading, the standing crop of periphyton on rocks can be reduced by herbivorous macroinvertebrates and fish, which may explain why total biovolume in Ozark streams was not strongly affected by water-quality (or other habitat) factors.

A macroinvertebrate index and several macroinvertebrate metrics were adversely affected by increasing urban and agricultural land use and associated environmental factors. Factors most commonly affecting the index and metrics included factors associated with water quality, stream geometry, sediment, land-use percentages, and road density. In general, the macroinvertebrate index was higher (indicative of least disturbance) at sites with greater percentages of forest in their basins, lower percentages of urban land in their basins, and lower paved road density. Upstream wastewater-treatment plants affected several metrics. For example, three of the five lowest macroinvertebrate index scores, two of the five lowest percent predator values, and two of the five highest percent gatherer-collector values were at sites downstream from wastewater-treatment plants.

The Ozark Highlands fish index of biotic integrity and several fish metrics were adversely affected by increasing urban and agricultural land use and associated factors. Factors affecting these metrics included factors associated with nutrients, sediment, and shading. In general, the fish index of biotic integrity was higher at sites with higher percentages of forest in their basins, lower percentages of urban land in their basins, higher unpaved road density, and lower paved and total road density. Upstream wastewater-treatment plants seemed to affect some fish community metrics substantially but had little effect on other metrics. For example, three of the five lowest relative abundances of lithophilic spawner minus stonerollers and four of the five highest stoneroller abundances were at sites downstream from wastewater-treatment plants.

Interpretations of the results of the study described in this report are limited by a number of factors. These factors individually and collectively add to uncertainty and variability in the responses to various environmental stresses. Notwithstanding the limiting factors, the biological responses 
of macroalgae cover and periphyton, macroinvertebrate, and fish metrics to environmental variables provide multiple lines of evidence that biological communities of these streams are affected by recent and ongoing land-use practices.

For several biological metrics there appears to be a threshold of about 40 to 50 percent forest where values of these metrics change in magnitude. However, the four sites with more than 50 percent forest in their basins were the four sites sampled in late May-early June of 2012 (rather than July-August of 2011). The relative influence of season and forest percentage on the biological communities at these sites is unknown.

\section{Introduction}

The Illinois River Basin (fig. 1) is an area of Arkansas undergoing substantial and rapid land-use changes, rapid population growth, and associated changes in water-quality and stream-habitat conditions (FTN Associates, Ltd., 2012); these changes can affect the biological communities in streams. The Ozark Plateaus province (which includes the Springfield Plateau and the Boston Mountains physiographic sections and contains the Illinois River Basin) is an area of relatively high biological diversity of aquatic species (Master and others, 1998; Petersen and others, 2008), The Illinois River Basin is 1 of 87 similarly-sized watersheds in the United States with 10 or more at-risk fish or mussel species (Master and others, 1998).

\section{Purpose and Scope}

The purpose of this report is to describe the biological communities (periphyton, macroinvertebrates, and fish) of wadeable streams (table 1) and effects of land use in the Illinois River Basin in Arkansas. Macroalgae (the algae with visible structure, rather than the typically microscopic algal structure of periphyton) cover also is described. Relations are shown between the biological communities and macroalgae, and environmental factors such as basin land use (for example, percent forest, poultry house density, and road density), stream habitat, and water quality. (These factors generally will be referred to as "environmental factors.")

The scope of this report is determined by several factors. The study area is limited to the part of the Illinois River Basin in Arkansas. Drainage area of sites was limited to a range of about 11 to 37 square miles $\left(\mathrm{mi}^{2}\right)$ to minimize the effect of stream size on the biological communities. Biological communities, macroalgae cover, and stream-habitat measures were sampled or measured once per site during 2011-12. Water-quality sampling was limited to a single base-flow sample per site that was analyzed for nutrients. Samples were not collected during storm events and were not analyzed for suspended sediment. Suspended sediment effects were estimated by measuring substrate embeddedness and turbidity caused by disturbance of gravel substrate. Samples were not analyzed for trace metals, pharmaceutical compounds, or other organic compounds.

\section{Description of Study Area}

The Illinois River Basin includes an area of diverse land use in northwestern Arkansas. Land-use data collected in 2006 indicate that most of the land in the basin is agricultural (46 percent, mostly pasture or poultry production) or urban (13 percent) (FTN Associates, Ltd., 2012). From 1992 to 2006 there was a shift from agricultural land use (which decreased from 64 to 46 percent) to urban land use (which increased from 6 to 13 percent) as the cities of Fayetteville, Springdale, and Rogers grew in area and in population (FTN Associates, Ltd., 2012). Forest plus herbaceous land use increased from 29 to 41 percent during the same period. Northwestern Arkansas (Benton and Washington Counties) more than doubled in population from approximately 210,900 in 1990 (U.S. Census Bureau, 2013a) to approximately 424,400 in 2010 (U.S. Census Bureau, 2013b).

The northern part of the basin lies in the Springfield Plateau and the southern part of the basin lies in the Boston Mountains physiographic section (Adamski and others, 1995). The gently rolling karst topography of the Springfield Plateau is underlain mostly by limestone. The geology associated with the karst topography results in a number of springs, sinkholes, caves, and gaining and losing streams and, therefore, a substantial connection between the surface water and the groundwater. The more rugged topography of the Boston Mountains is underlain mostly by sandstone and shale.

Activities related to the mixed land use in Illinois River Basin have affected water-quality and other hydrologic and biological conditions. Agricultural activities (as measured by percent agricultural land upstream from sites) have been related to higher concentrations of nutrients in streams in the basin or nearby parts of the Ozarks (Petersen and others, 1998; Davis and Bell, 1998; Justus and others, 2010; FTN Associates, Ltd., 2012). Agricultural activities also can cause increases in bacteria concentrations (Davis and Bell, 1998) and suspended sediment. Riparian (forested) corridors often are narrowed or eliminated in agricultural and urban areas, which can increase bank erosion and increase the amount of sunlight reaching the stream. Construction activities and general disturbance in urban areas also can be a source of suspended sediment. Wastewater-treatment plants (WWTPs) can be sources of nutrients, trace metals, pharmaceutical and personal care products, and other organic compounds. Several WWTPs (including plants serving Lincoln, Fayetteville, Rogers, Springdale, and Siloam Springs) discharge into streams in the basin (FTN Associates, Ltd., 2012). Finally, the increased impervious cover (such as roads, parking lots, and roof tops) causes increased runoff from precipitation, thus altering the natural streamflow patterns downstream from urban areas. Paul and Meyer (2001) and Coles and others (2012) provide overviews of the effects of urbanization on streams. 


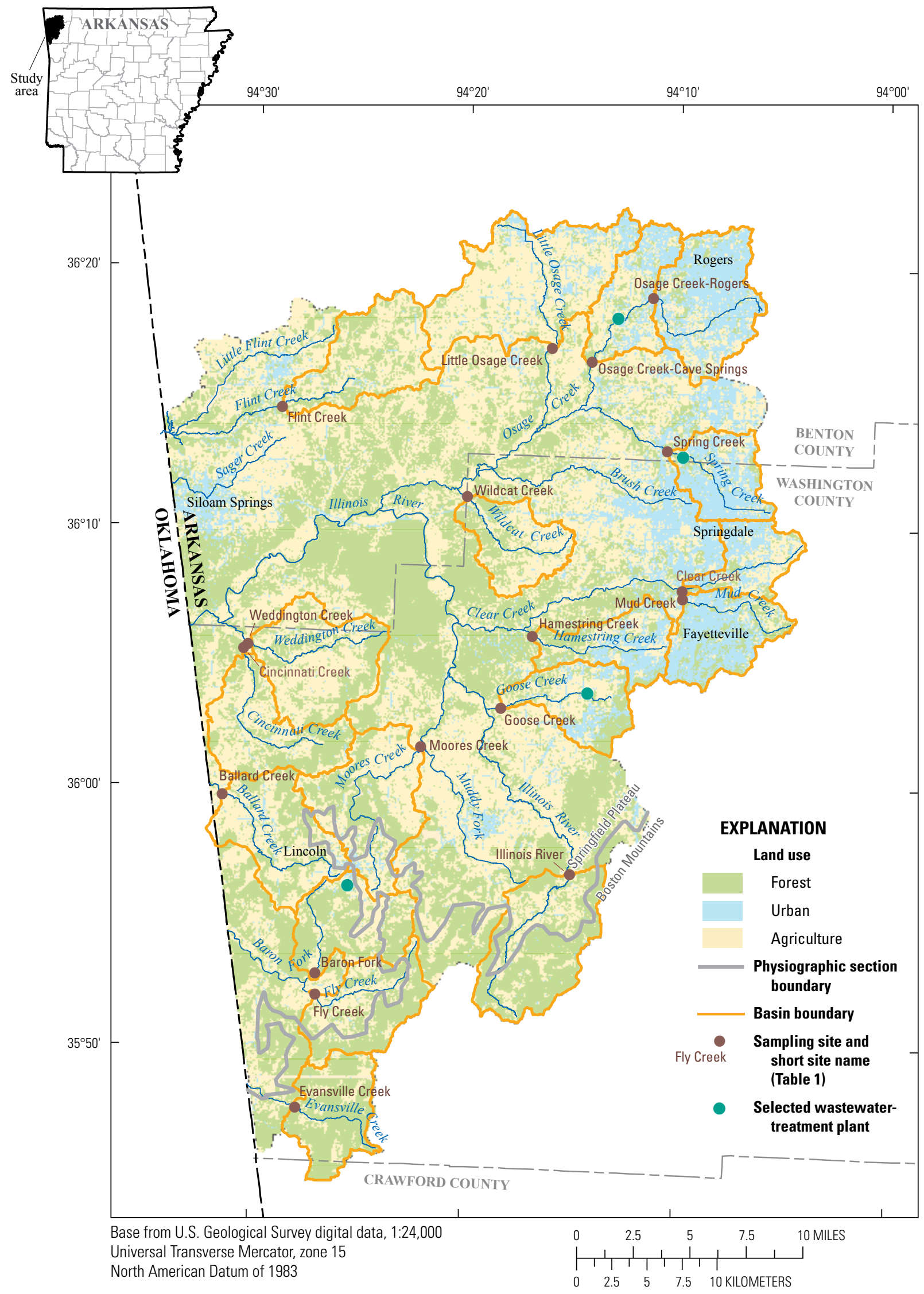

Figure 1. Map showing Illinois River Basin study area and sampling sites. 
Table 1. List of sampling sites and related information for the Illinois River Basin study area.

[USGS, U.S. Geological Survey; $\mathrm{mi}^{2}$, square mile; WWTP, wastewater-treatment plant; mi, mile; NA, not applicable]

\begin{tabular}{|c|c|c|c|c|c|c|c|c|c|c|c|c|}
\hline USGS station name & $\begin{array}{c}\text { Short } \\
\text { site name }\end{array}$ & $\begin{array}{c}\text { USGS } \\
\text { station } \\
\text { identifica- } \\
\text { tion number }\end{array}$ & Latitude & Longitude & $\begin{array}{l}\text { Drainage } \\
\text { area } \\
\left(\mathrm{mi}^{2}\right)\end{array}$ & $\begin{array}{l}\text { Forest } \\
\text { site }\end{array}$ & $\begin{array}{l}\text { Agri- } \\
\text { culture } \\
\text { site }\end{array}$ & $\begin{array}{l}\text { Urban } \\
\text { site }\end{array}$ & $\begin{array}{l}\text { Agriculture } \\
\text { gradient } \\
\text { site }\end{array}$ & $\begin{array}{c}\text { Urban } \\
\text { gradient } \\
\text { site }\end{array}$ & $\begin{array}{l}\text { WWTP } \\
\text { upstream }\end{array}$ & $\begin{array}{c}\text { Distance } \\
\text { downstream } \\
\text { from WWTP } \\
\text { (mi) }\end{array}$ \\
\hline $\begin{array}{l}\text { Ballard Creek near Summers, } \\
\text { Arkansas }\end{array}$ & Ballard Creek & 07195452 & 355938.22 & 0943126.69 & 21.6 & No & Yes & No & Yes & No & No & NA \\
\hline $\begin{array}{l}\text { Baron Fork near Morrow, } \\
\text { Arkansas }\end{array}$ & Baron Fork & 07196880 & 355241.73 & 0942702.64 & 17.3 & No & Yes & No & No & No & Yes & 4.9 \\
\hline $\begin{array}{l}\text { Cincinnati Creek near } \\
\text { Cincinnati, Arkansas }\end{array}$ & Cincinnati Creek & 07195427 & 360517.16 & 0943032.76 & 19.8 & No & Yes & No & Yes & No & No & NA \\
\hline $\begin{array}{l}\text { Clear Creek near Johnson, } \\
\text { Arkansas }\end{array}$ & Clear Creek & 07194812 & 360739.97 & 0940946.55 & 10.6 & No & No & Yes & No & Yes & No & NA \\
\hline $\begin{array}{l}\text { Evansville Creek near } \\
\text { Evansville, Arkansas }\end{array}$ & Evansville Creek & 07196940 & 354743.24 & 0942757.98 & 15.8 & Yes & No & No & Yes & Yes & No & NA \\
\hline $\begin{array}{l}\text { Flint Creek near Gentry, } \\
\text { Arkansas }\end{array}$ & Flint Creek & 07195820 & 361435.66 & 0942852.14 & 20.2 & No & Yes & No & Yes & No & No & NA \\
\hline $\begin{array}{l}\text { Fly Creek near Morrow, } \\
\text { Arkansas }\end{array}$ & Fly Creek & 07196890 & 355201.18 & 0942702.88 & 17.5 & No & Yes & No & Yes & No & No & NA \\
\hline $\begin{array}{l}\text { Goose Creek near } \\
\text { Farmington, Arkansas }\end{array}$ & Goose Creek & 07194758 & 360304.14 & 0941819.19 & 14.3 & No & Yes & No & No & No & Yes & 4.8 \\
\hline $\begin{array}{l}\text { Hamestring Creek near } \\
\text { Wheeler, Arkansas }\end{array}$ & Hamestring Creek & 07194811 & 360551.86 & 0941652.1 & 13.4 & No & No & Yes & No & Yes & No & NA \\
\hline $\begin{array}{l}\text { Illinois River near Hogeye, } \\
\text { Arkansas }\end{array}$ & Illinois River & 07194735 & 355646.56 & 0941504.95 & 25.7 & Yes & No & No & Yes & Yes & No & NA \\
\hline $\begin{array}{l}\text { Little Osage Creek near } \\
\text { Osage Mills, Arkansas }\end{array}$ & Little Osage Creek & 07194945 & 361658.48 & 0941604.87 & 35.4 & No & Yes & No & Yes & No & No & NA \\
\hline $\begin{array}{l}\text { Moores Creek northeast of } \\
\text { Rhea, Arkansas }\end{array}$ & Moores Creek & 071947888 & 360132.81 & 0942204.84 & 24.7 & No & Yes & No & Yes & No & No & NA \\
\hline $\begin{array}{l}\text { Mud Creek near Johnson, } \\
\text { Arkansas }\end{array}$ & Mud Creek & 071948095 & 360722.11 & 0940945.22 & 16.0 & No & No & Yes & No & Yes & No & NA \\
\hline $\begin{array}{l}\text { Osage Creek northwest of } \\
\text { Cave Springs, Arkansas }\end{array}$ & $\begin{array}{l}\text { Osage Creek-Cave } \\
\text { Springs }\end{array}$ & 07194887 & 361627.66 & 0941410.79 & 37.4 & No & No & Yes & No & No & Yes & 3.1 \\
\hline $\begin{array}{l}\text { Osage Creek at Rogers, } \\
\text { Arkansas }\end{array}$ & $\begin{array}{l}\text { Osage Creek- } \\
\text { Rogers }\end{array}$ & 07194852 & 361855.84 & 0941118.17 & 22.8 & No & No & Yes & No & Yes & No & NA \\
\hline $\begin{array}{l}\text { Spring Creek upstream from } \\
\text { I-540 near Springdale, } \\
\text { Arkansas }\end{array}$ & Spring Creek & 071949063 & 361303.36 & 0941032.77 & 13.1 & No & No & Yes & No & No & Yes & 1.1 \\
\hline $\begin{array}{l}\text { Weddington Creek near } \\
\text { Cincinnati, Arkansas }{ }^{1}\end{array}$ & Weddington Creek & 07195425 & 360526.92 & 0943019.51 & 23.2 & No & Yes & No & Yes & No & No & NA \\
\hline $\begin{array}{l}\text { Wildcat Creek near } \\
\text { Robinson, Arkansas }\end{array}$ & Wildcat Creek & 07195223 & 361113.09 & 0942001.54 & 14.0 & No & Yes & No & Yes & No & No & NA \\
\hline
\end{tabular}


Thirteen stream segments within the study area are listed as impaired water bodies by the Arkansas Department of Environmental Quality and the U.S. Environmental Protection Agency (FTN Associates, Ltd., 2012). These stream segments are listed as impaired because they do not meet water-quality standards or criteria or do not support designated beneficial uses; constituents or contaminants causing impairment include phosphorus, nitrate, suspended sediment, pathogenic bacteria, and metals. Potential sources of contaminants include surface erosion, agricultural and urban land use (including municipal point sources), failing septic systems, and unknown sources (FTN Associates, Ltd., 2012). The 13 stream segments are located on Osage Creek, Little Osage Creek, Spring Creek, Sager Creek, Clear Creek, Muddy Fork, Baron Fork, and Illinois River (fig. 1). All of the impaired stream segments were sampled as part of this study, with the exception of Sager Creek, which has a very small drainage area.

\section{Weather Conditions During the Sampling Periods}

Weather conditions preceding and during the JulySeptember 2011 and the May-June 2012 sampling periods were abnormally hot and dry. Mean daily high temperatures near Fayetteville, Ark. (Drake Field), were 6.8, 9.1, and 5.6 degrees Fahrenheit $\left({ }^{\circ} \mathrm{F}\right)$ warmer than the normal (19812010) temperatures of $83.6,88.6$, and $89.1^{\circ} \mathrm{F}$ in June, July, and August 2011, respectively (National Climatic Data Center, 2013). Precipitation was 4.00 and 2.61 inches lower than the normal (1981-2010) of 4.95 and 3.24 inches in June and July of 2011. August was wetter than normal, but most of the rainfall occurred on August 10-12, after the last day of sampling in August 2011. Almost no precipitation occurred between August 12 and September 13, the last day of sample collection in 2011. Warmer than normal temperatures and low precipitation also occurred in April and May of 2012. April and May mean temperatures were 4.2 and $6.4^{\circ} \mathrm{F}$ warmer than the normal temperatures of 69.3 and $76,1^{\circ} \mathrm{F}$, respectively. April and May precipitation values were 2.45 and 4.86 inches lower than normal precipitation values of 4.60 and 5.91 inches, respectively.

\section{Previous Investigations}

Four previous studies of the effects of land use on stream biota in the Illinois River Basin of Arkansas have been published. The studies provide a framework for the current study.

Water quality (31 sites), periphyton (15 sites), benthic macroinvertebrates (18 sites), fish (10 sites), and fish habitat (9 sites) were sampled in 1995 and 1996 by the Arkansas Department of Environmental Quality (Arkansas Department of Environmental Quality, 1997). Most sites were on the main stems of the Illinois River, Osage Creek, Spring Creek, Mud
Creek, Clear Creek, or Muddy Fork. The objective of the study was to quantify and determine the impacts of four WWTPs on the Illinois River. The ADEQ sampling occurred prior to improvements in effluent quality at many of the WWTPs in the basin. An attempt was made to compare results from the 1995-96 study with the current (2011-12) study. However, the small number of sites in common between the two studies and differences in site location, sampling methods, and laboratory analysis methods precluded any rigorous assessment of changes in stream condition between the two studies.

From August 2003 through January 2004 and at 11 sites in the Illinois River Basin, Parsons and the University of Arkansas (2004) sampled water quality (nutrients, chlorophyll, total organic carbon, dissolved solids, turbidity, and field measurements); habitat; periphyton, macroinvertebrates, and fish communities; and periphyton algal production. The study focused on the effects of WWTPs. Sites were characterized as unimpacted to severely impacted based on a range of factors including point sources and nonpoint sources of water-quality constituents, urbanization, and agricultural activities.

A study by Stevenson (undated) included more than 50 sites in Arkansas and Oklahoma. Sites were sampled for water quality, algae, macroinvertebrates, and fish.

Most recently, McGoodwin, Williams, and Yates, Inc. (2009) sampled 10 sites in the Illinois River Basin in Arkansas. With the exception of two "reference" sites, all sites were on Osage Creek and Spring Creek. Sites were sampled for water quality, algae, macroinvertebrates, and fish.

\section{Methods}

Methods for collection and analysis of data are described below. Data-collection methods generally follow U.S. Geological Survey (USGS) National Water-Quality Assessment (NAWQA) Program biological sampling methods. Data-analysis methods generally were limited to approaches for aggregating data, calculating biological metrics and indices, and describing relations between biological metrics and indices and environmental factors (table 2).

\section{Data-Collection Methods}

During April of 2011, a reconnaissance of approximately 40 candidate sites was conducted. Candidate sites were selected based on drainage area and qualitative land-use estimates. During the reconnaissance a field test kit was used to measure nutrient (phosphorus and nitrate) concentrations; qualitative information related to local land use, habitat factors, and access also was obtained.

Eighteen sites (table 1) were selected from the list of candidate sites based on drainage area, land use, presence or absence of an upstream WWTP, water-quality, and other information gathered during the reconnaissance. An important 
Table 2. List of environmental factors compared to biological metrics and indices.

[NA, not applicable]

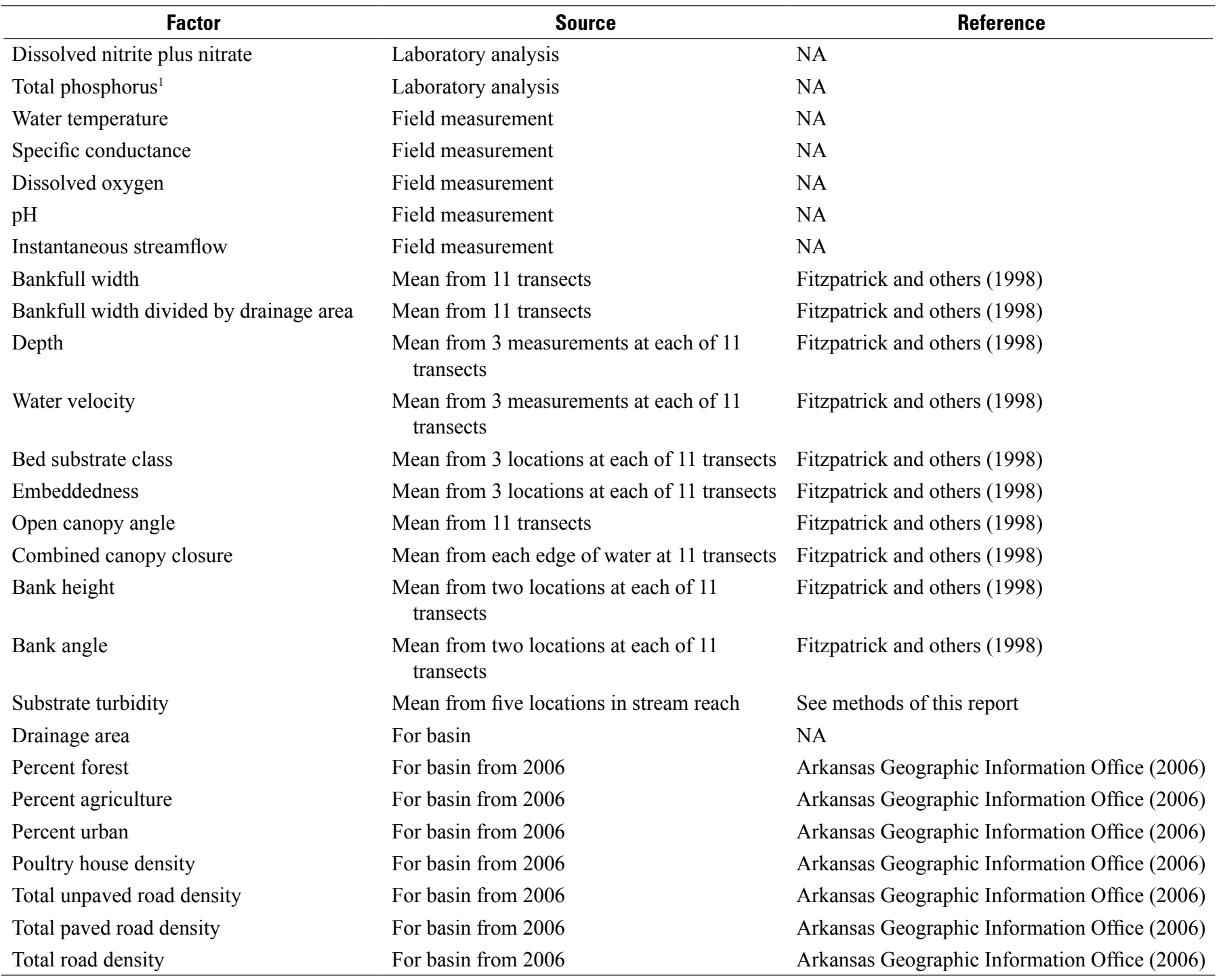

${ }^{1}$ Total phosphorus, rather than orthophosphorus, was selected because the State of Oklahoma's water-quality standard (Oklahoma Water Resources Board, 2013 ) is for total phosphorus, and total phosphorus and orthophosphorus are strongly correlated (rho $=0.96$ ).

consideration in the process was to select sites along gradients of forest to urban land use (hereafter, the urban gradient) and forest to agricultural land use (hereafter, the agricultural gradient). Most sites along both land-use gradients had a mix of all three land-use types in the part of the basin upstream from the site.

Most sites were sampled in July or August of 2011. Four sites (Evansville Creek, Illinois River, Fly Creek, and Baron Fork) were not sampled in 2011 because of low streamflow conditions; these sites were sampled in late May or early June of 2012. Water-quality samples were collected from each site prior to biological sampling. Samples were collected using standard USGS methods (U.S. Geological Survey, variously dated) for analysis of nutrients (dissolved ammonia, dissolved nitrite plus nitrate, dissolved nitrite, organic nitrogen, orthophosphorus, and total phosphorus). A multiparameter field meter was used to measure water temperature, specific conductance, $\mathrm{pH}$, and dissolved oxygen. Streamflow was measured immediately following the water-quality sampling. Water-quality samples were submitted to the USGS National Water Quality Laboratory, Denver, Colorado, for analysis (Fishman, 1993; Patton and Kryskalla, 2003). A duplicate sample was collected at two sites and analyzed in 2011 and in 2012. Relative percent differences between the primary sample and the duplicate generally were less than 5 percent (table 3). Water-quality data were stored in the USGS National Water Information System water-quality database (http:// waterdata.usgs.gov/nwis/qw/). 
Table 3. Relative percent differences between primary and duplicate water-quality samples collected in 2011 and 2012 in the Illinois River Basin study area.

[N, nitrogen; P, phosphorus; relative percent difference is absolute value of primary sample minus duplicate sample divided by average of the two samples and multiplied by 100 . All concentrations are in milligrams per liter; $<$, less than; ND is not determinable]

\begin{tabular}{|c|c|c|c|c|c|c|c|}
\hline & $\begin{array}{c}\text { Ammonia } \\
\text { as } \mathbf{N}\end{array}$ & $\begin{array}{c}\text { Nitrite } \\
\text { plus nitrate } \\
\text { as } \mathbf{N}\end{array}$ & $\begin{array}{c}\text { Nitrite } \\
\text { as N }\end{array}$ & $\begin{array}{c}\text { Organic } \\
\text { nitrogen } \\
\text { as } \mathbf{N}\end{array}$ & $\begin{array}{c}\text { Total } \\
\text { nitrogen } \\
\text { as } \mathbf{N}\end{array}$ & $\begin{array}{l}\text { Orthophos- } \\
\text { phorus } \\
\text { as P }\end{array}$ & $\begin{array}{c}\text { Total } \\
\text { phosphorus } \\
\text { as } \mathbf{P}\end{array}$ \\
\hline Fly Creek & 0.017 & 3.2 & 0.0196 & 0.003 & 3.2 & 0.027 & 0.040 \\
\hline Fly Creek (duplicate) & 0.017 & 3.2 & 0.0205 & 0.166 & 3.4 & 0.027 & 0.036 \\
\hline Relative percent difference & 0.0 & 0.0 & 2.3 & 96.4 & 3.0 & 0.0 & 5.3 \\
\hline Osage Creek-Cave Springs (duplicate) & $<0.010$ & 2.7 & 0.0054 & $<0.237$ & 2.9 & 0.158 & 0.179 \\
\hline Relative percent difference & ND & 1.9 & 3.6 & ND & 0.0 & 0.0 & 2.3 \\
\hline
\end{tabular}

Periphyton and macroinvertebrate communities were sampled from five riffles within a stream reach at each site using USGS NAWQA Program methods (Moulton and others, 2002); methods are briefly described herein. Periphyton samples were collected from five rocks at each of five riffle locations at each site. To clean each rock, a 2-inch diameter polyvinyl chloride (PVC) cylinder was placed on the surface of each rock, and all the periphyton outside the cylinder was removed using a wire brush. After the rock surface was cleaned, the remaining periphyton from the area inside the PVC cylinder was removed with a wire brush, rinsed into a sample container, and preserved with formalin. Total sample area, sample volume, and preservative volume were recorded and used to calculate periphyton density (cells per area) and periphyton biomass (cell volume per area). Periphyton samples were submitted to the BSA Environmental Services, Inc. (http://www.bsaenv.com/index.html/) for identification and analysis.

Macroinvertebrates were collected from areas immediately adjacent to the areas where periphyton samples were collected using a Slack sampler with an area of $0.5 \times 0.5$ meter. Macroinvertebrate samples were sieved through a 500-micron sieve and preserved with formalin. Macroinvertebrate samples were submitted to Versar, Inc. (http://www.esm.versar.com/) for identification and analysis.

Fish were collected using a backpack electrofisher. Two passes were made in the stream reach, one along each bank and extending to the centerline of the stream in an upstream direction. Segments of three riffles in the stream reach also were sampled using the electrofisher and a seine; the substrate upstream from the seine was disturbed by kicking while electrofishing in a downstream direction. Fish were counted, identified in the field when possible, and released. Fish that could not be identified in the field were preserved in formalin for laboratory identification.
Stream habitat in the stream reach was assessed using NAWQA Program protocols (Fitzpatrick and others, 1998); methods are briefly described herein. Habitat measurements were made along 11 equally spaced transects spanning the length of the sampling reach. The length of the sampling reach was approximately 20 times the wetted width of the stream and typically was about 200 meters in length.

During the habitat measurement, macroalgae cover was visually estimated. Macroalgae cover was estimated at each of five quadrats (two edges of water and three locations spaced at equal intervals across the transect) at the 11 transects within each reach. Each quadrat was approximately 1 meter $\times$ 1 meter.

One additional habitat measurement that qualitatively estimated the degree of intergravel sedimentation at each sampling site was not part of the NAWQA Program protocols. At each of five locations in runs or shallow pools of the stream reach, a 3-foot section of 8-inch inside diameter PVC pipe with a foam lip was pressed into the gravel substrate so that a seal was formed. The shallow water inside the pipe and just above the substrate was agitated for 30 seconds using a stirrer constructed of a 4-inch wide $\times 3$-inch tall paddle secured to a 40-inch section of 1-inch PVC pipe. The multiparameter field meter was used to measure turbidity (in nephelometric turbidity units) within the PVC pipe at 30-second intervals for 2 minutes. The turbidity measured after 60 seconds is termed "substrate turbidity" in this report. The depth of the water within the pipe was recorded (but for consistency, locations with a depth of approximately 1.0 foot were targeted.)

Geographic information system (GIS) data were used to describe the characteristics of the basin upstream from each of the 18 sites. The characteristics of interest were basin size, land-use percentage, number of poultry houses per square mile, and density of several road types per square mile Characteristics were estimated using data from the Arkansas Geographic Information Office (2006). 


\section{Data-Analysis Methods}

Sites were grouped into site categories and ultimately into two land-use gradient groups based on basin land use. The categories were forest, agriculture, urban, agriculture with upstream WWTP, and urban with upstream WWTP (table 1). The two forest sites and the agriculture sites (not including the two with an upstream WWTP) were combined into the agriculture gradient group (table 1). The two forest sites and the urban sites (not including the two with an upstream WWTP) were combined into the urban gradient group (table 1).

Spearman's rho correlation and scatterplots were used to examine relations between selected water quality, habitat, and land-use factors (listed in table 2) and biological metrics. These examinations generally were conducted among sites chosen for each gradient. The two sites with the highest percentage of forest land use are in both gradient groups. Spearman's rho correlations are reported without reporting associated $p$-values because a table of exact $p$-values (such as table 13 in Bhattacharyya and Johnson, 1977) should be used with sample sizes of less than 20 (Helsel and Hirsch, 2002). Many statistical software packages do not report exact p-values for small sample sizes. Correlations are characterized in this report as strong or moderately strong (or moderate) based on the values of rho, the sample size, and, when given in table 13 of Bhattacharyya and Johnson (1977), the p-value:

- Sample size of 6 - strong, absolute values of rho greater than or equal to 0.80 ; moderately strong, absolute values of rho greater than or equal to 0.65 ;

- Sample size of 10 - strong, absolute values of rho greater than or equal to 0.60 ; moderately strong, absolute values of rho greater than or equal to 0.45 ; and

- Sample sizes of 14 and 18 - strong, absolute values of rho greater than or equal to 0.50 ; moderately strong, absolute values of rho greater than or equal to 0.40 .

The values of rho used to characterize correlation strength for sample sizes of 6 and 10 approximate values associated with p-values of 0.05 and 0.10 , respectively, in Bhattacharyya and Johnson (1977). The values of rho used for sample sizes of 14 and 18 were arbitrarily selected because p-values for this sample size are not given in Bhattacharyya and Johnson (1977).

Biological metrics were chosen based on one or more criteria - previous use in other investigations; relevance based on previous use in the literature; expected relations to one or more characteristics expected to be affected by nutrients, suspended sediment, or other disturbances; or perceived patterns of differences in biological metrics related to various site categorizations. Macroinvertebrate data were processed using the Invertebrate Data Analysis System (Cuffney and Brightbill, 2011); metrics were calculated based on a series of macroinvertebrate attribute tables in the Invertebrate Data Analysis System. Periphyton metrics were calculated using methods similar to those used for macroinvertebrates (Thomas F. Cuffney, U.S. Geological Survey, written commun., 2013) and using algal attributes from Porter (2008). Fish metrics were calculated based on attributes reported in Dauwalter and others (2003) and Petersen and others (2008).

A macroinvertebrate index was developed specifically for this study. The first step in the process used to develop the macroinvertebrate index involved comparing a large number of biological metrics to potential chemical and physical stressors (or associated surrogates). More than 100 macroinvertebrate metrics that included measures and classes of behavior, feeding, tolerance (to water pollution and habitat degradation), and taxonomic relative abundance and richness were compared to potential explanatory environmental variables. Values for richness, percent richness, abundance, and percent relative abundance were evaluated for all but a few metrics (for which percentages were not beneficial to the analysis, for example, diversity indices).

Macroinvertebrate metrics were selected for the macroinvertebrate index based primarily on correlations to the percentage of forest in the basins of the 18 sites, but correlations to water quality and habitat variables also were considered. Five metrics that (1) had strong correlations to the amount of forest, (2) were ecologically relevant, and (3) were not autocorrelated (absolute value of rho greater than 0.70) were selected for inclusion in the macroinvertebrate index. Approximately 20 macroinvertebrate metrics were correlated to a number of the test variables; however, many of those metrics had taxa that overlapped with other metrics resulting in a high incidence of autocorrelation. Other macroinvertebrate metrics had spurious relations to environmental variables and were not considered because they lacked ecological relevance. Eventually, five macroinvertebrate metrics that generally had moderately strong to strong correlations to percent forest or percent urban (five metrics, none of these five were strongly correlated to percent agriculture), specific conductance or total phosphorus (four metrics), riparian cover variables (two metrics), and total road density (five metrics) were selected for the macroinvertebrate index. Those five metrics included number of taxa belonging to Ephemeroptera, Plecoptera, Trichoptera; percentage of total richness composed of predators; percentage of total abundance composed of gatherer-collectors; percentage of total abundance composed of Baetidae; and Margalef diversity (Margalef, 1958).

Scores for the macroinvertebrate index were calculated by combining values for the five metrics using a centering method (Justus, 2003). An advantage of the centering method is that it is more robust than other scoring methods (for example, scores range from 0 to 100 rather than tiered, preassigned metric classes of 1,3 , or 5). A disadvantage of the centering method is that it does not facilitate comparison of sites from independent data sets because metric scores are based on the range of sampling conditions that may not include least- or most-impaired sites. Given that only 18 sites were sampled, the application of this index is probably limited to the current study and may not be applicable to studies in other basins. 
The centering method uses one of two scoring procedures depending on if high or low metric values represent least-disturbed conditions. If a high metric value indicated least-degraded conditions, the metric value was first divided by the maximum metric value (for all 18 sites), and the resulting quotient was multiplied by 100 to obtain a metric score. To obtain a metric score if low metric values indicated least-disturbed conditions, the metric value was again divided by the maximum metric value, but the resulting quotient was subtracted from 1 before being multiplied by 100. Scores for the five metrics were averaged to obtain an index score. Sites having the highest macroinvertebrate index scores were assumed to have the least-disturbed conditions. Natural breaks in the index score values were used to distinguish between the four classes: poor (less than 40), fair (greater than or equal to 40 but less than 50), good (greater than or equal to 59 but less than 67), and least disturbed (greater than or equal to 81).

\section{Classes of Environmental Factors Affecting Biological Communities}

There are three classes of environmental factors that affect the biological communities in small streams in the Illinois River Basin of Arkansas-land use, stream habitat, and water quality. Values for selected factors in each of these classes are described below.

\section{Land-Use Factors Associated With Stream Basins}

Basin land-use percentages varied substantially among the 18 sites (fig. 2, table 4). Forest land use ranged from 11.9 to 79.4 percent. Agricultural land use (which is pasture or grassland) ranged from 12.2 to 69.5 percent. Urban land use ranged from 0.4 to 65.5 percent.

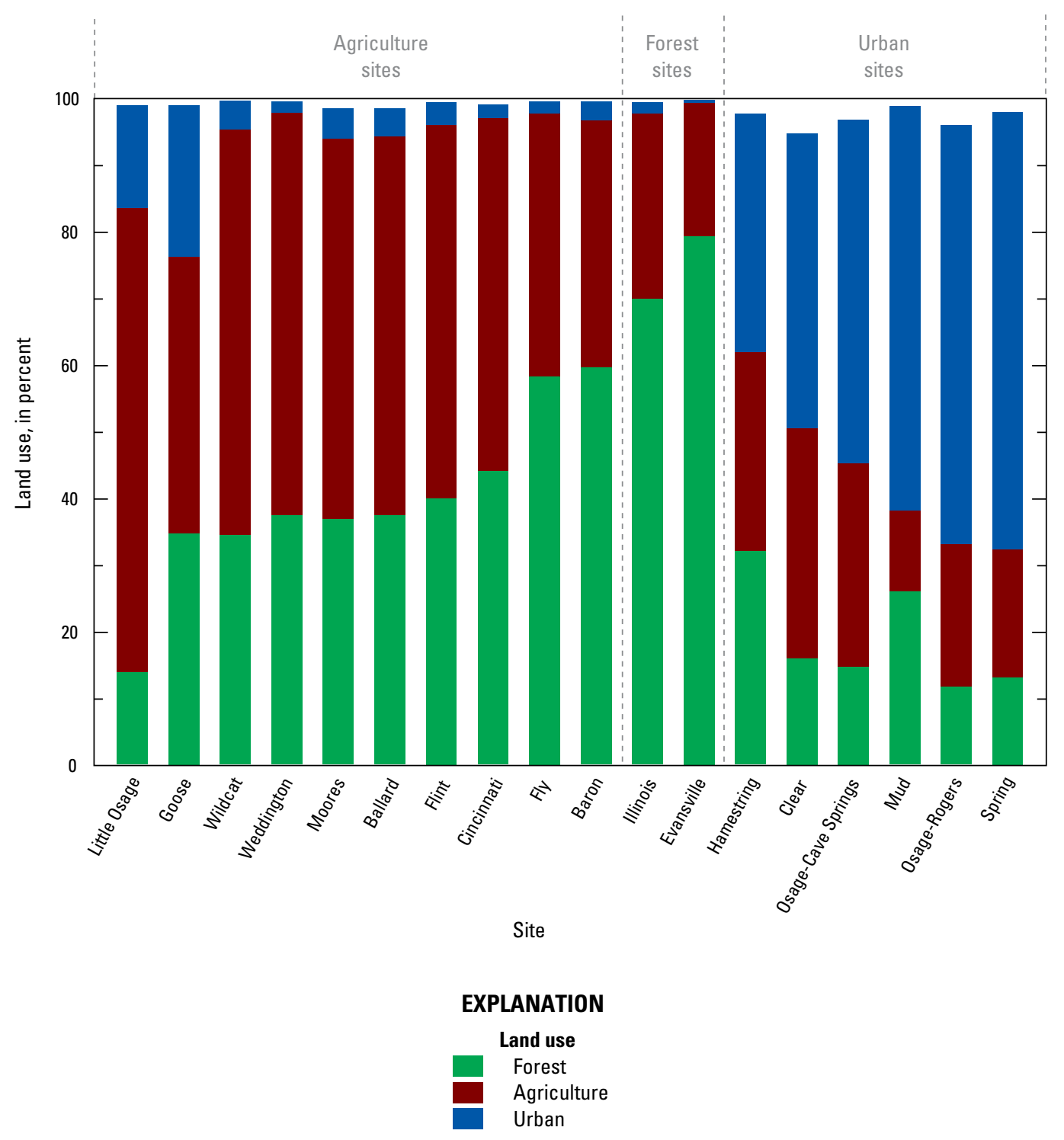

Figure 2. Land-use variation among sites along land-use gradients in the Illinois River Basin study area. 
Table 4. Land-use percentages, poultry house density, and road density associated with sampling sites in the Illinois River Basin study area.

[WWTP, wastewater-treatment plant; $\mathrm{mi}^{2}$, square mile]

\begin{tabular}{|c|c|c|c|c|c|c|c|c|c|c|c|c|c|}
\hline Short site name & $\begin{array}{l}\text { Agri- } \\
\text { culture } \\
\text { gradient } \\
\text { site }\end{array}$ & $\begin{array}{l}\text { Agri- } \\
\text { culture } \\
\text { site }\end{array}$ & $\begin{array}{c}\text { Urban } \\
\text { gradient } \\
\text { site }\end{array}$ & $\begin{array}{c}\text { Urban } \\
\text { site }\end{array}$ & $\begin{array}{l}\text { Forest } \\
\text { site }\end{array}$ & $\begin{array}{c}\text { WWTP } \\
\text { upstream }\end{array}$ & $\begin{array}{c}\text { Percent } \\
\text { forest }\end{array}$ & $\begin{array}{c}\text { Percent } \\
\text { agriculture }\end{array}$ & $\begin{array}{c}\text { Percent } \\
\text { urban }\end{array}$ & $\begin{array}{c}\text { Poultry } \\
\text { house } \\
\text { density } \\
\text { (per mi²) }\end{array}$ & $\begin{array}{c}\text { Total } \\
\text { unpaved } \\
\text { road } \\
\text { density } \\
\text { (miles } \\
\text { per } \mathrm{mi}^{2} \text { ) }\end{array}$ & $\begin{array}{c}\text { Total } \\
\text { paved } \\
\text { road } \\
\text { density } \\
\text { (miles } \\
\text { per } \text { mi }^{2} \text { ) }\end{array}$ & $\begin{array}{c}\text { Total } \\
\text { road } \\
\text { density } \\
\text { (miles } \\
\text { per mi2) }\end{array}$ \\
\hline Evansville Creek & Yes & No & Yes & No & Yes & No & 79.4 & 20.0 & 0.4 & 1.7 & 2.2 & 0.4 & 2.6 \\
\hline Illinois River & Yes & No & Yes & No & Yes & No & 70.1 & 27.8 & 1.6 & 1.9 & 1.6 & 0.7 & 2.3 \\
\hline Ballard Creek & Yes & Yes & No & No & No & No & 37.6 & 56.8 & 4.2 & 6.7 & 2.0 & 1.5 & 3.5 \\
\hline Cincinnati Creek & Yes & Yes & No & No & No & No & 44.2 & 52.8 & 2.1 & 6.6 & 2.2 & 0.5 & 2.7 \\
\hline Flint Creek & Yes & Yes & No & No & No & No & 40.1 & 56.1 & 3.4 & 6.1 & 3.0 & 0.9 & 3.9 \\
\hline Fly Creek & Yes & Yes & No & No & No & No & 58.4 & 39.5 & 1.8 & 4.9 & 2.2 & 0.8 & 3.0 \\
\hline Little Osage Creek & Yes & Yes & No & No & No & No & 14.1 & 69.5 & 15.4 & 4.4 & 2.0 & 2.5 & 4.4 \\
\hline Moores Creek & Yes & Yes & No & No & No & No & 37.0 & 57.0 & 4.5 & 5.2 & 2.5 & 1.5 & 4.0 \\
\hline Weddington Creek & Yes & Yes & No & No & No & No & 37.6 & 60.3 & 1.6 & 2.5 & 1.9 & 1.0 & 2.8 \\
\hline Wildcat Creek & Yes & Yes & No & No & No & No & 34.7 & 60.7 & 4.3 & 3.7 & 2.3 & 1.3 & 3.6 \\
\hline Baron Fork & No & Yes & No & No & No & Yes & 59.7 & 37.1 & 2.7 & 5.2 & 1.8 & 1.1 & 2.9 \\
\hline Goose Creek & No & Yes & No & No & No & Yes & 34.8 & 41.5 & 22.7 & 0.8 & 2.1 & 3.8 & 6.0 \\
\hline Clear Creek & No & No & Yes & Yes & No & No & 16.0 & 34.5 & 44.2 & 4.3 & 1.7 & 6.2 & 7.9 \\
\hline Hamestring Creek & No & No & Yes & Yes & No & No & 32.2 & 29.9 & 35.7 & 0.9 & 1.4 & 7.2 & 8.6 \\
\hline Mud Creek & No & No & Yes & Yes & No & No & 26.1 & 12.2 & 60.6 & 0.2 & 0.9 & 12.2 & 13.1 \\
\hline Osage Creek-Rogers & No & No & Yes & Yes & No & No & 11.9 & 21.4 & 62.8 & 0.1 & 0.6 & 10.9 & 11.4 \\
\hline Osage Creek-Cave Springs & No & No & No & Yes & No & Yes & 14.8 & 30.4 & 51.6 & 0.1 & 0.7 & 9.6 & 10.3 \\
\hline Spring Creek & No & No & No & Yes & No & Yes & 13.2 & 19.2 & 65.5 & 0.5 & 0.6 & 11.9 & 12.5 \\
\hline
\end{tabular}


Several environmental factors (table 2) were strongly or moderately correlated with percent forest, percent agriculture, or percent urban land use (table 5). Correlations of four environmental factors probably were substantially affected by the low streamflow at the most-forested sites (negative correlations of streamflow, depth, and velocity with percent forest; positive correlation of bankfull width with percent forest; and opposite correlations of these factors with percent urban). Each of the road density factors was strongly correlated with percent forest and percent urban. Total unpaved road density also was strongly correlated with percent agriculture. Poultry house density was strongly correlated with percent forest, percent agriculture, and percent urban. Specific conductance was strongly correlated with percent forest and percent urban, possibly largely the result of geologic

Table 5. Correlations between land-use percentages and selected environmental factors in the Illinois River Basin study area.

[Red font denotes absolute value of rho is greater than or equal to 0.50 ]

\begin{tabular}{lrcr}
\hline & $\begin{array}{c}\text { Percent } \\
\text { forest }\end{array}$ & $\begin{array}{c}\text { Percent } \\
\text { agriculture }\end{array}$ & $\begin{array}{c}\text { Percent } \\
\text { urban }\end{array}$ \\
\hline Percent forest & 1.00 & 0.11 & -0.93 \\
Percent agriculture & 0.11 & 1.00 & -0.33 \\
Percent urban & -0.93 & -0.33 & 1.00 \\
Nitrite plus nitrate & -0.26 & 0.48 & 0.14 \\
Total phosphorus & -0.17 & 0.41 & 0.17 \\
Temperature & 0.16 & -0.00 & -0.12 \\
Specific conductance & -0.68 & -0.19 & 0.68 \\
Dissolved oxygen & 0.09 & 0.34 & -0.06 \\
pH & -0.03 & 0.19 & 0.06 \\
Streamflow & -0.67 & 0.21 & 0.57 \\
Bankfull width & 0.55 & -0.07 & -0.46 \\
Drainage area & 0.08 & 0.33 & -0.23 \\
Bankfull width/drainage area & 0.21 & -0.28 & -0.08 \\
Depth & -0.63 & -0.00 & 0.53 \\
Velocity & -0.67 & 0.07 & 0.57 \\
Bed substrate & 0.36 & -0.23 & -0.33 \\
Embeddedness & -0.28 & -0.19 & 0.40 \\
Substrate turbidity & 0.25 & -0.27 & -0.12 \\
Open canopy angle & -0.13 & -0.09 & 0.07 \\
Combined canopy closure & -0.12 & 0.16 & 0.16 \\
Bank height & 0.23 & -0.33 & 0.02 \\
Bank angle & -0.03 & -0.05 & -0.07 \\
Poultry house density & 0.52 & 0.66 & -0.55 \\
Total unpaved road density & 0.57 & 0.64 & -0.61 \\
Total paved road density & -0.89 & -0.35 & 0.96 \\
Total road density & -0.89 & -0.35 & 0.97 \\
\hline & & & \\
& & & \\
& & &
\end{tabular}

differences at the least forested sites and point-source and nonpoint-source contributions of WWTPs and urban activities. Nutrients were moderately correlated with percent agriculture. Embeddedness was moderately correlated with percent urban. In summary, sites with higher percentages of forest land use tended to be associated with lower streamflow, lower specific conductance, higher poultry house density, higher unpaved road density, and lower paved road density. Sites with higher percentages of agriculture land use were associated with higher nutrient concentrations, higher poultry house density, and higher unpaved road density. Sites with higher percentages of urban land use were associated with higher streamflow, higher specific conductance, more embeddedness, lower poultry house density, lower unpaved road density, and higher paved road density.

Poultry house density varied greatly among the 18 sites and ranged from 0.1 to 6.7 per $\mathrm{mi}^{2}$ (table 4 ). The mean for forest sites $\left(1.8\right.$ per $\left.\mathrm{mi}^{2}\right)$ was slightly higher than the mean for urban sites and substantially lower than the mean for the agriculture category sites. Means for urban and urban with WWTP sites $\left(1.0\right.$ per $\left.\mathrm{mi}^{2}\right)$ and agriculture and agriculture with WWTP sites $\left(4.6\right.$ per $\left.\mathrm{mi}^{2}\right)$ were substantially different from each other.

Total road density varied greatly among the 18 sites and ranged from 2.3 to $13.1 \mathrm{mi}^{2} \mathrm{mi}^{2}$ (table 4 ). The mean total road density for forest sites $\left(2.4 \mathrm{mi}\right.$ per $\left.\mathrm{mi}^{2}\right)$ was substantially lower than the mean for any other land-use category. Means for urban and urban with WWTP sites $\left(10.6 \mathrm{mi} \mathrm{per} \mathrm{mi}^{2}\right)$ and agriculture and agriculture with WWTP sites $\left(3.7 \mathrm{mi}\right.$ per $\left.\mathrm{mi}^{2}\right)$ were substantially different from each other.

Paved road density varied greatly among the 18 sites

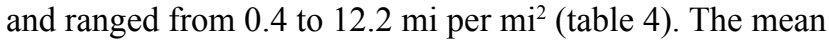
for forest sites $\left(0.5 \mathrm{mi}\right.$ per $\left.\mathrm{mi}^{2}\right)$ was substantially lower than the mean for any other land-use category. Means for urban and urban with WWTP sites $\left(9.7 \mathrm{mi}\right.$ per $\left.\mathrm{mi}^{2}\right)$ and agriculture and agriculture with WWTP sites $\left(1.5 \mathrm{mi}\right.$ per $\left.\mathrm{mi}^{2}\right)$ were substantially different from each other.

Unpaved road density was less variable than paved road density among the 18 sites and ranged from 0.6 to $3.0 \mathrm{mi}$ per $\mathrm{mi}^{2}$ (table 4). The mean unpaved road densities for forest sites (1.9 mi per $\left.\mathrm{mi}^{2}\right)$ and agriculture and agriculture with WWTP sites $\left(2.2 \mathrm{mi}\right.$ per $\mathrm{mi}^{2}$ ) were similar. The mean for urban and urban with WWTP sites $\left(1.0 \mathrm{mi}\right.$ per $\left.\mathrm{mi}^{2}\right)$ was substantially different from the other land-use categories.

\section{Habitat Factors Associated With Stream Reaches}

Several habitat factors, including measures of streamflow, channel geometry, substrate quality (substrate class, embeddedness, and substrate turbidity), and riparian shading (open canopy angle and canopy closure), were measured as part of the habitat field effort (tables 2 and 6). A subset of those factors (one streamflow, one channel geometry, one substrate quality, one shading factor) is described below. 
Table 6. Habitat factor values associated with sampling sites in the Illinois River Basin study area.

[WWTP, wastewater-treatment plant; $\mathrm{ft}^{3} / \mathrm{s}$, cubic feet per second; ft, feet; $\mathrm{ft} / \mathrm{mi}^{2}$, feet per square mile; deg, degrees; s, second]

\begin{tabular}{|c|c|c|c|c|c|c|c|c|c|c|c|c|c|c|c|c|}
\hline Short site name & $\begin{array}{l}\text { Agri- } \\
\text { culture } \\
\text { gradient } \\
\text { site }\end{array}$ & $\begin{array}{l}\text { Urban } \\
\text { gradient } \\
\text { site }\end{array}$ & $\begin{array}{c}\text { WWTP } \\
\text { upstream }\end{array}$ & $\begin{array}{c}\text { Stream- } \\
\text { flow } \\
\left(\mathrm{ft}^{3} / \mathrm{s}\right)\end{array}$ & $\begin{array}{c}\text { Wetted } \\
\text { channel } \\
\text { width } \\
\text { (ft) }\end{array}$ & $\begin{array}{c}\text { Bankfull } \\
\text { width } \\
\text { (ft) }\end{array}$ & $\begin{array}{c}\text { Bankfull } \\
\text { width/ } \\
\text { drain- } \\
\text { age } \\
\text { area } \\
\left(\mathrm{ft} / \mathrm{mi}^{2}\right)\end{array}$ & $\begin{array}{c}\text { Bank } \\
\text { height } \\
\text { (ft) }\end{array}$ & $\begin{array}{c}\text { Bank } \\
\text { angle } \\
\text { (deg) }\end{array}$ & $\begin{array}{c}\text { Open } \\
\text { canopy } \\
\text { angle } \\
\text { (deg) }\end{array}$ & $\begin{array}{c}\text { Canopy } \\
\text { closure } \\
\text { (per- } \\
\text { cent) }\end{array}$ & $\begin{array}{l}\text { Depth } \\
\text { (ft) }\end{array}$ & $\begin{array}{c}\text { Velocity } \\
\text { (ft/sec) }\end{array}$ & $\begin{array}{l}\text { Bed } \\
\text { sub- } \\
\text { strate } \\
\text { class }\end{array}$ & $\begin{array}{c}\text { Embed- } \\
\text { dedness } \\
\text { (per- } \\
\text { cent) }\end{array}$ & $\begin{array}{c}\text { Substrate } \\
\text { turbidity } \\
\text { (neph- } \\
\text { elometric } \\
\text { turbidity } \\
\text { units at } \\
60 \mathrm{~s} \text { ) }\end{array}$ \\
\hline $\begin{array}{c}\text { Evansville } \\
\text { Creek }\end{array}$ & Yes $^{1}$ & Yes $^{1}$ & No & 0.21 & 16.9 & 99.9 & 6.3 & 9.5 & 53.4 & 60.0 & 52.9 & 0.6 & 0.45 & 5.9 & 28 & 308 \\
\hline Illinois River & Yes $^{1}$ & Yes $^{1}$ & No & 0.12 & 18.5 & 153.3 & 6.0 & 9.5 & 65.3 & 82.7 & 30.3 & 0.7 & 0.03 & 6.1 & 13 & 209 \\
\hline Ballard Creek & $\mathrm{Yes}^{2}$ & No & No & 4.15 & 30.2 & 105.7 & 4.9 & 8.3 & 37.7 & 50.0 & 70.9 & 0.5 & 0.12 & 3.2 & 19 & 98 \\
\hline $\begin{array}{l}\text { Cincinnati } \\
\text { Creek }\end{array}$ & $\mathrm{Yes}^{2}$ & No & No & 1.62 & 19.0 & 111.3 & 5.6 & 7.9 & 62.0 & 90.9 & 35.6 & 0.9 & 0.46 & 4.3 & 35 & 108 \\
\hline Flint Creek & Yes $^{2}$ & No & No & 9.16 & 26.9 & 70.7 & 3.5 & 9.5 & 48.4 & 65.0 & 83.7 & 0.9 & 0.68 & 3.8 & 36 & 154 \\
\hline Fly Creek & $\mathrm{Yes}^{2}$ & No & No & 0.37 & 31.0 & 94.8 & 5.4 & 9.5 & 67.3 & 50.9 & 63.1 & 0.5 & 0.11 & 4.8 & 29 & 210 \\
\hline $\begin{array}{l}\text { Little Osage } \\
\text { Creek }\end{array}$ & $\mathrm{Yes}^{2}$ & No & No & 14.6 & 28.6 & 61.7 & 1.7 & 9.5 & 62.0 & 52.7 & 75.1 & 1.0 & 1.08 & 4.2 & 15 & 138 \\
\hline Moores Creek & $\mathrm{Yes}^{2}$ & No & No & 0.94 & 17.0 & 69.2 & 2.8 & 12.3 & 60.2 & 30.9 & 81.3 & 1.0 & 0.32 & 3.7 & 84 & 590 \\
\hline $\begin{array}{l}\text { Weddington } \\
\text { Creek }\end{array}$ & $\mathrm{Yes}^{2}$ & No & No & 4.30 & 31.0 & 83.2 & 3.6 & 7.6 & 54.3 & 80.0 & 49.7 & 1.1 & 0.44 & 4.2 & 26 & 64 \\
\hline Wildcat Creek & $\mathrm{Yes}^{2}$ & No & No & 5.71 & 28.6 & 111.8 & 8.0 & 9.5 & 56.1 & 131.8 & 21.7 & 0.7 & 0.56 & 4.2 & 49 & 156 \\
\hline Baron Fork & $\mathrm{No}^{2}$ & No & Yes & 2.44 & 30.4 & 86.2 & 5.0 & 9.5 & 47.3 & 54.5 & 68.4 & 0.6 & 0.45 & 5.2 & 44 & 288 \\
\hline Goose Creek & $\mathrm{No}^{2}$ & No & Yes & 7.93 & 27.1 & 95.4 & 6.7 & 11.0 & 49.1 & 90.0 & 39.4 & 0.9 & 0.74 & 5.3 & 22 & 94 \\
\hline Clear Creek & No & $\mathrm{Yes}^{3}$ & No & 1.74 & 17.7 & 81.4 & 7.7 & 6.9 & 36.8 & 36.4 & 74.3 & 1.1 & 0.46 & 6.1 & 42 & 104 \\
\hline $\begin{array}{l}\text { Hamestring } \\
\text { Creek }\end{array}$ & No & $\mathrm{Yes}^{3}$ & No & 3.04 & 27.7 & 85.0 & 6.3 & 10.6 & 67.0 & 48.2 & 72.7 & 1.2 & 0.45 & 4.1 & 44 & 117 \\
\hline Mud Creek & No & $\mathrm{Yes}^{3}$ & No & 1.03 & 33.5 & 110.8 & 6.9 & 10.3 & 47.3 & 68.2 & 68.4 & 0.8 & 0.18 & 3.2 & 48 & 353 \\
\hline $\begin{array}{l}\text { Osage Creek- } \\
\text { Rogers }\end{array}$ & No & $\mathrm{Yes}^{3}$ & No & 5.72 & 28.9 & 44.7 & 2.0 & 9.5 & 49.1 & 97.3 & 55.3 & 1.3 & 0.93 & 3.2 & 63 & 229 \\
\hline $\begin{array}{l}\text { Osage Creek- } \\
\text { Cave Springs }\end{array}$ & No & $\mathrm{No}^{3}$ & Yes & 19.2 & 35.2 & 89.2 & 2.4 & 9.5 & 61.6 & 120.9 & 15.8 & 1.3 & 0.96 & 4.2 & 7 & 87 \\
\hline Spring Creek & No & $\mathrm{No}^{3}$ & Yes & 24.9 & 39.7 & 68.9 & 5.3 & 9.5 & 73.9 & 74.5 & 61.0 & 0.8 & 0.95 & 4.9 & 60 & 108 \\
\hline
\end{tabular}


Streamflow varied greatly among the 18 sites and ranged from 0.12 to 24.9 cubic feet per second $\left(\mathrm{ft}^{3} / \mathrm{s}\right)$ (table 6$)$. The mean streamflow for forest sites $\left(0.164 \mathrm{ft}^{3} / \mathrm{s}\right)$ was substantially lower than the mean for any other land-use category Means for urban and urban with WWTP sites $\left(9.27 \mathrm{ft}^{3} / \mathrm{s}\right)$ and agriculture and agriculture with WWTP sites $\left(5.12 \mathrm{ft}^{3} / \mathrm{s}\right)$ were substantially different from each other. The mean for the urban with WWTP sites was $22.0 \mathrm{ft}^{3} / \mathrm{s}$.

Bankfull width varied substantially among the 18 sites and ranged from 44.7 to $153.3 \mathrm{ft}$ (table 6). Mean bankfull widths for urban and urban with WWTP sites $(80.0 \mathrm{ft})$ and agriculture and agriculture with WWTP sites $(89.0 \mathrm{ft})$ were similar but were substantially less than the mean bankfull width for the two forest sites (126.6 ft).

Substrate embeddedness also varied substantially among the 18 sites and ranged from 7 to 84 percent (table 6). Mean substrate embeddedness for urban and urban with WWTP sites (36 percent) and agriculture and agriculture with WWTP sites (44 percent) were similar but were substantially greater than the mean for forest sites (20 percent).

Open canopy angle varied substantially among the sites and ranged from 30.9 to 131.8 degrees (table 6). However, mean open canopy angles for urban and urban with WWTP sites (69.7 degrees), agriculture and agriculture with WWTP sites (74.2 degrees), and forest sites (71.4 degrees) were similar.

\section{Water-Quality Factors Associated With Stream Reaches}

Nutrient concentrations varied substantially among the 18 sites. Concentrations of nitrite plus nitrate and total phosphorus generally were within the range of reported concentrations in small agricultural Ozark streams (Justus and others, 2010) and in small to large agricultural, and urban Ozark streams (Davis and Bell, 1998; Petersen and others, 1998).

Total nitrite plus nitrate (hereafter referred to as nitrate) concentrations varied greatly among the 18 sites, and ranged from 0.17 to $7.4 \mathrm{mg} / \mathrm{L}$ as nitrogen (table 7 ). The mean nitrate concentration for forest sites $(0.38 \mathrm{mg} / \mathrm{L})$ was substantially lower than the mean for any other land-use category . Means for urban and urban with WWTP sites $(1.82 \mathrm{mg} / \mathrm{L})$ and agriculture and agriculture with WWTP sites $(3.28 \mathrm{mg} / \mathrm{L})$ were substantially different from each other.

Total phosphorus concentrations varied greatly among the 18 sites and ranged from 0.010 to $0.483 \mathrm{mg} / \mathrm{L}$ as phosphorus (table 7). The mean total phosphorus concentration for forest sites $(0.01 \mathrm{mg} / \mathrm{L})$ was substantially lower than the mean for any other land-use category . Means for urban and urban with WWTP sites $(0.13 \mathrm{mg} / \mathrm{L})$ and agriculture and agriculture with WWTP sites $(0.08 \mathrm{mg} / \mathrm{L})$ were substantially different from each other, but the difference was because of the $0.483 \mathrm{mg} / \mathrm{L}$ concentration at the site on Spring Creek.

Specific conductance varied greatly among the 18 sites and ranged from 103 to 672 microsiemens per centimeter at 25 degrees Celsius $\left(\mu \mathrm{S} / \mathrm{cm}\right.$ at $\left.25^{\circ} \mathrm{C}\right)$ (table 7$)$. Lowest values occurred at sites with substantial parts of their basins in the Boston Mountains; surficial geology of the Boston Mountains is dominated by relatively insoluble sandstones and shales (Adamski and others, 1995). The mean specific conductance for forest sites $\left(120 \mu \mathrm{S} / \mathrm{cm}\right.$ at $\left.25^{\circ} \mathrm{C}\right)$ was substantially lower than the mean for any other land-use category. Highest specific conductance occurred at sites downstream from WWTPs and in urban basins although some high specific conductivity values may also indicate groundwater influence. Means for urban and urban with WWTP sites $(429 \mu \mathrm{S} / \mathrm{cm}$ at $25^{\circ} \mathrm{C}$ ) and agriculture and agriculture with WWTP sites $\left(305 \mu \mathrm{S} / \mathrm{cm}\right.$ at $\left.25^{\circ} \mathrm{C}\right)$ were substantially different from each other.

Dissolved oxygen concentrations (typically measured in midmorning) varied greatly among the 18 sites and ranged from 1.6 to $10.0 \mathrm{mg} / \mathrm{L}$ (table 7). The mean dissolved oxygen concentration for forest sites $(3.9 \mathrm{mg} / \mathrm{L})$ was somewhat lower than the mean for any other land-use category. Means for urban and urban with WWTP sites $(4.7 \mathrm{mg} / \mathrm{L})$ and agriculture and agriculture with WWTP sites $(6.9 \mathrm{mg} / \mathrm{L})$ were substantially different from each other. Concentrations were less than $5 \mathrm{mg} / \mathrm{L}$ (the critical season standard for the Ozark Highland streams that were sampled; Arkansas Pollution Control and Ecology Commission, 2011) at 5 of the 18 sites; these 5 sites included 2 agricultural sites, 2 urban sites, and 1 forest site. 
Table 7. Water-quality data associated with sampling sites in the Illinois River Basin study area.

[WWTP, wastewater-treatment plant; mg/L, milligrams per liter; N, nitrogen; P, phosphorus; deg C, degrees Celsius; $\mu \mathrm{S} / \mathrm{cm}$, microsiemens per centimeter at 25 degrees Celsius; ND is not determined; <, less than]

\begin{tabular}{|c|c|c|c|c|c|c|c|c|c|c|c|c|c|c|c|c|}
\hline $\begin{array}{c}\text { Short } \\
\text { site name }\end{array}$ & $\begin{array}{c}\text { Agri- } \\
\text { culture } \\
\text { gradi- } \\
\text { ent site }\end{array}$ & $\begin{array}{l}\text { Urban } \\
\text { gradi- } \\
\text { ent site }\end{array}$ & $\begin{array}{c}\text { WWTP } \\
\text { up- } \\
\text { stream }\end{array}$ & Date & $\begin{array}{l}\text { Local } \\
\text { time }\end{array}$ & $\begin{array}{c}\text { Ammonia } \\
\text { (mg/L } \\
\text { as } \mathrm{N})\end{array}$ & $\begin{array}{c}\text { Nitrite } \\
\text { plus } \\
\text { nitrate } \\
\text { (mg/L } \\
\text { as } \mathrm{N} \text { ) }\end{array}$ & $\begin{array}{l}\text { Nitrite } \\
\text { (mg/L } \\
\text { as N) }\end{array}$ & $\begin{array}{c}\begin{array}{c}\text { Organic } \\
\text { nitrogen } \\
\text { (mg/L }\end{array} \\
\text { as } \mathrm{N} \text { ) }\end{array}$ & $\begin{array}{c}\text { Total } \\
\text { nitrogen } \\
\text { (mg/L } \\
\text { as } \mathrm{N} \text { ) }\end{array}$ & $\begin{array}{c}\text { Ortho- } \\
\text { phos- } \\
\text { phorus } \\
\text { (mg/L } \\
\text { as P) }\end{array}$ & $\begin{array}{c}\text { Total } \\
\text { phos- } \\
\text { phorus } \\
\text { (mg/L } \\
\text { as P) }\end{array}$ & $\begin{array}{c}\text { Temper- } \\
\text { ature } \\
(\operatorname{deg} C)\end{array}$ & $\begin{array}{c}\text { Specific } \\
\text { conduc- } \\
\text { tance } \\
(\mu \mathrm{S} / \mathrm{cm})\end{array}$ & $\begin{array}{c}\text { Dis- } \\
\text { solved } \\
\text { oxygen } \\
(\mathrm{mg} / \mathrm{L})\end{array}$ & $\begin{array}{c}\text { pH } \\
\text { (stan- } \\
\text { dard } \\
\text { units) }\end{array}$ \\
\hline Evansville Creek & Yes $^{1}$ & Yes $^{1}$ & No & $5 / 29 / 2012$ & 1147 & $<0.010$ & 0.58 & ND & $<0.037$ & 0.62 & 0.005 & 0.010 & 28.3 & 137 & 2.5 & 7.29 \\
\hline Illinois River & Yes $^{1}$ & Yes $^{1}$ & No & $5 / 30 / 2012$ & 1040 & 0.011 & 0.17 & $<0.0010$ & 0.028 & 0.21 & 0.006 & 0.012 & 25.1 & 103 & 5.3 & 7.28 \\
\hline Ballard Creek & $\mathrm{Yes}^{2}$ & No & No & $7 / 19 / 2011$ & 1030 & 0.058 & 0.78 & 0.0374 & 0.418 & 1.3 & 0.042 & 0.079 & 29.0 & 302 & 9.8 & 7.47 \\
\hline Cincinnati Creek & $\mathrm{Yes}^{2}$ & No & No & $7 / 27 / 2011$ & 830 & $<0.010$ & 2.2 & 0.0071 & $<0.279$ & 2.4 & 0.067 & 0.074 & 27.4 & 310 & 3.1 & 7.15 \\
\hline Flint Creek & Yes $^{2}$ & No & No & $8 / 9 / 2011$ & 1145 & 0.011 & 3.7 & 0.0047 & 0.279 & 4.0 & 0.057 & 0.064 & 25.2 & 252 & 8.7 & 7.64 \\
\hline Fly Creek & Yes $^{2}$ & No & No & $5 / 31 / 2012$ & 920 & 0.017 & 3.2 & 0.0196 & 0.003 & 3.2 & 0.027 & 0.040 & 20.8 & 373 & 7.2 & 6.98 \\
\hline $\begin{array}{l}\text { Little Osage } \\
\text { Creek }\end{array}$ & $\mathrm{Yes}^{2}$ & No & No & $8 / 3 / 2011$ & 830 & 0.012 & 5.2 & 0.0112 & ND & 5.1 & 0.035 & 0.045 & 20.6 & 345 & 6.6 & 7.35 \\
\hline Moores Creek & Yes $^{2}$ & No & No & $7 / 26 / 2011$ & 800 & 0.116 & 0.81 & 0.0384 & 0.578 & 1.5 & 0.184 & 0.271 & 26.3 & 273 & 2.2 & 7.21 \\
\hline $\begin{array}{l}\text { Weddington } \\
\text { Creek }\end{array}$ & Yes $^{2}$ & No & No & $7 / 28 / 2011$ & 830 & $<0.010$ & 2.9 & 0.0025 & $<0.052$ & 2.9 & 0.077 & 0.077 & 25.9 & 321 & 5.1 & 7.43 \\
\hline Wildcat Creek & $\mathrm{Yes}^{2}$ & No & No & $8 / 2 / 2011$ & 900 & 0.011 & 3.8 & 0.0036 & 0.092 & 3.9 & 0.060 & 0.059 & 26.9 & 292 & 7.3 & 7.66 \\
\hline Baron Fork & $\mathrm{No}^{2}$ & No & Yes & $6 / 1 / 2012$ & 934 & 0.020 & 2.8 & 0.0235 & 0.325 & 3.2 & 0.052 & 0.071 & 17.7 & 137 & 9.0 & 7.88 \\
\hline Goose Creek & $\mathrm{No}^{2}$ & No & Yes & $7 / 18 / 2011$ & 1130 & 0.015 & 7.4 & 0.0130 & 0.644 & 8.0 & 0.045 & 0.052 & 25.5 & 445 & 10.0 & 7.36 \\
\hline $\begin{array}{l}\text { Hamestring } \\
\text { Creek }\end{array}$ & No & Yes $^{3}$ & No & $7 / 25 / 2011$ & 930 & $<0.010$ & 1.5 & 0.0063 & $<0.156$ & 1.6 & 0.026 & 0.030 & 22.9 & 337 & 6.8 & 7.26 \\
\hline Mud Creek & No & $\mathrm{Yes}^{3}$ & No & $7 / 20 / 2011$ & ND & 0.031 & 0.79 & 0.0133 & 0.158 & 0.98 & 0.012 & 0.018 & 27.0 & 439 & 2.0 & 7.42 \\
\hline $\begin{array}{l}\text { Osage Creek- } \\
\text { Rogers }\end{array}$ & No & $\mathrm{Yes}^{3}$ & No & $9 / 13 / 2011$ & 730 & 0.013 & 3.3 & 0.0039 & 0.269 & 3.6 & 0.013 & 0.019 & 17.8 & 387 & 6.5 & 6.50 \\
\hline Clear Creek & No & $\mathrm{Yes}^{3}$ & No & $7 / 21 / 2011$ & 900 & 0.015 & 0.45 & 0.0018 & 0.180 & 0.65 & 0.039 & 0.049 & 26.1 & 252 & 1.6 & 7.34 \\
\hline $\begin{array}{l}\text { Osage Creek- } \\
\text { Cave Springs }\end{array}$ & No & $\mathrm{No}^{3}$ & Yes & $8 / 4 / 2011$ & 830 & $<0.010$ & 2.6 & 0.0058 & $<0.259$ & 2.9 & 0.158 & 0.171 & 24.4 & 487 & 5.9 & 7.30 \\
\hline Spring Creek & No & $\mathrm{No}^{3}$ & Yes & $8 / 2 / 2011$ & 800 & 0.020 & 2.3 & 0.0052 & 0.489 & 2.8 & 0.433 & 0.483 & 26.4 & 672 & 5.6 & 7.66 \\
\hline
\end{tabular}

${ }^{1}$ Forest site.

${ }^{2}$ Agriculture site.

${ }^{3}$ Urban site. 


\section{Description of Biological Communities and Relations to Land Use, Stream Habitat, and Water Quality}

\section{Macroalgae}

The presence of large macroalgae mats was one of the most noticeable biological characteristics in several streams within the Illinois River Basin. Macroalgae were present in the water along the banks of many of the streams during the 2011 and 2012 sampling seasons, usually floating on the surface or attached to rocks or macrophytes.

The highest macroalgae percent cover values were recorded at four sites downstream from WWTPs (fig. 3). The mean percent cover at these four sites downstream from WWTPs was 21.0 percent and ranged from 13.8 to 30.9 percent (table 8 , table 1 ). The mean macroalgae percent cover at these four sites was considerably higher than the mean macroalgae percent cover of the urban and agriculture sites not influenced by WWTPs (4.8 and 5.3 percent, respectively) or the forest sites $(2.9$ percent) (table 8 , table 1$)$.
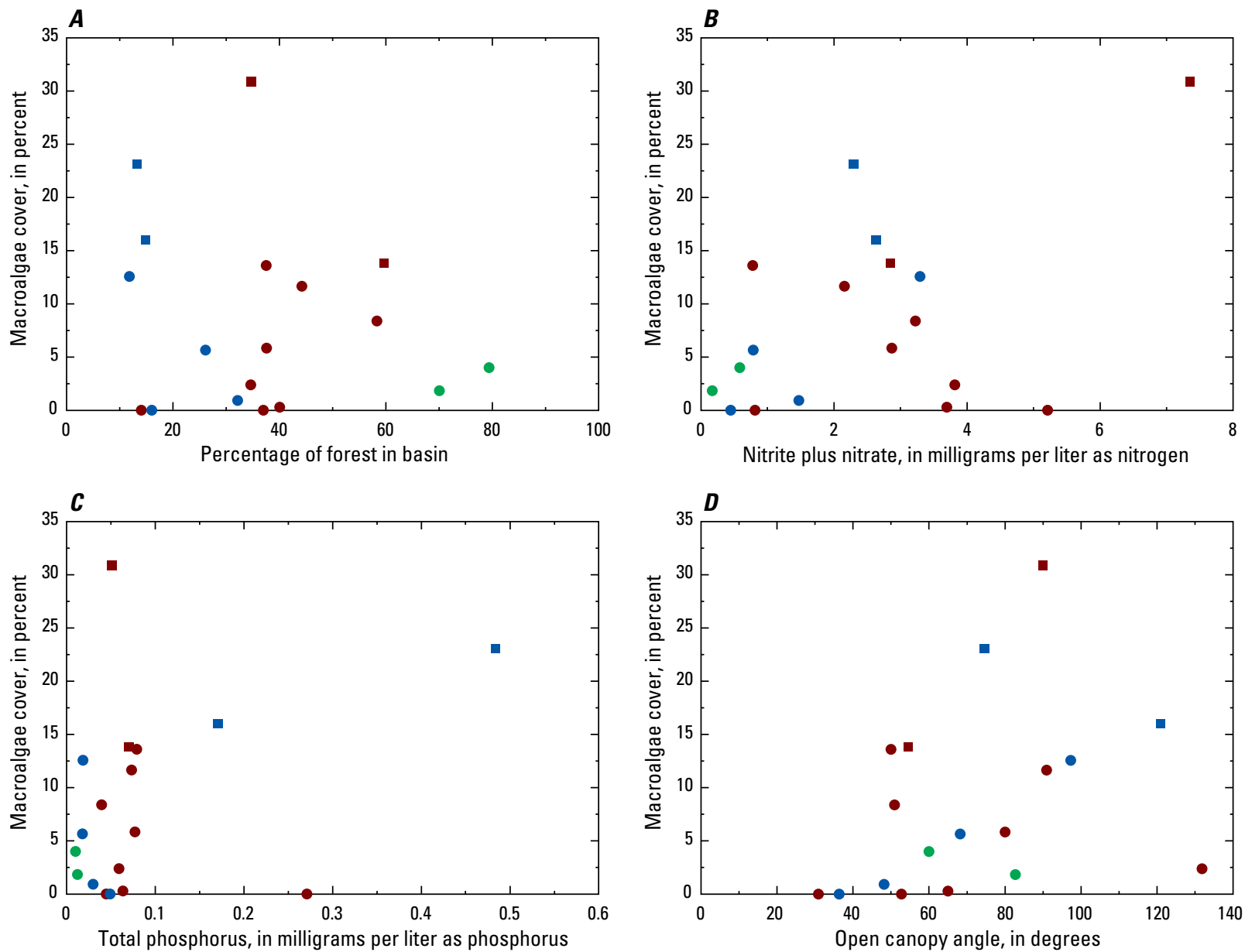

EXPLANATION

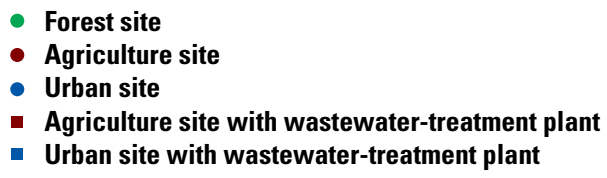

Figure 3. Scatterplots showing relation between macroalgae percent cover and selected environmental factors in the Illinois River Basin study area. 
Table 8. Macroalgae percent cover and values for selected environmental factors for sampling sites in the Illinois River Basin study area.

[Sites are sorted by macroalgae cover value; $\mathrm{mg} / \mathrm{L}$, milligrams per liter; $\mathrm{N}$, nitrogen; $\mathrm{P}$, phosphorus; $\mathrm{mi}^{2}$, square mile]

\begin{tabular}{|c|c|c|c|c|c|c|c|c|}
\hline Short site name & $\begin{array}{c}\text { Macroalgae } \\
\text { cover } \\
\text { (percent) }\end{array}$ & $\begin{array}{c}\text { Nitrite } \\
\text { plus nitrate } \\
\text { (mg/L as N) }\end{array}$ & $\begin{array}{c}\text { Total } \\
\text { phosphorus } \\
\text { (mg/L as P) }\end{array}$ & $\begin{array}{c}\text { Open } \\
\text { canopy } \\
\text { angle } \\
\text { (degrees) }\end{array}$ & $\begin{array}{l}\text { Percent } \\
\text { forest }\end{array}$ & $\begin{array}{c}\text { Percent } \\
\text { agriculture }\end{array}$ & $\begin{array}{c}\text { Percent } \\
\text { urban }\end{array}$ & $\begin{array}{c}\text { Poultry } \\
\text { house } \\
\text { density } \\
\text { (per mi²) }\end{array}$ \\
\hline Goose Creek ${ }^{1}$ & 30.9 & 7.4 & 0.052 & 90.0 & 34.8 & 41.5 & 22.7 & 0.8 \\
\hline Spring Creek ${ }^{1}$ & 23.1 & 2.3 & 0.483 & 74.5 & 13.2 & 19.2 & 65.5 & 0.5 \\
\hline Osage-Cave Springs ${ }^{1}$ & 16.0 & 2.6 & 0.171 & 120.9 & 14.8 & 30.4 & 51.6 & 0.1 \\
\hline Baron Fork ${ }^{1}$ & 13.8 & 2.8 & 0.071 & 54.5 & 59.7 & 37.1 & 2.7 & 5.2 \\
\hline Ballard Creek & 13.6 & 0.78 & 0.079 & 50.0 & 37.6 & 56.8 & 4.2 & 6.7 \\
\hline Osage-Rogers & 12.5 & 3.3 & 0.019 & 97.3 & 11.9 & 21.4 & 62.8 & 0.1 \\
\hline Cincinnati Creek & 11.6 & 2.2 & 0.074 & 90.9 & 44.2 & 52.8 & 2.1 & 6.6 \\
\hline Fly Creek & 8.4 & 3.2 & 0.040 & 50.9 & 58.4 & 39.5 & 1.8 & 4.9 \\
\hline Weddington Creek & 5.8 & 2.9 & 0.077 & 80.0 & 37.6 & 60.3 & 1.6 & 2.5 \\
\hline Mud Creek & 5.6 & 0.79 & 0.018 & 68.2 & 26.1 & 12.2 & 60.6 & 0.2 \\
\hline Evansville Creek & 4.0 & 0.59 & 0.010 & 60.0 & 79.4 & 20.0 & 0.4 & 1.7 \\
\hline Wildcat Creek & 2.4 & 3.8 & 0.059 & 131.8 & 34.7 & 60.7 & 4.3 & 3.7 \\
\hline Illinois River & 1.8 & 0.17 & 0.012 & 82.7 & 70.1 & 27.8 & 1.6 & 1.9 \\
\hline Hamestring Creek & 0.9 & 1.5 & 0.030 & 48.2 & 32.2 & 29.9 & 35.7 & 0.9 \\
\hline Flint Creek & 0.3 & 3.7 & 0.064 & 65.0 & 40.1 & 56.1 & 3.4 & 6.1 \\
\hline Clear Creek & 0.0 & 0.45 & 0.049 & 36.4 & 16.0 & 34.5 & 44.2 & 4.3 \\
\hline Little Osage Creek & 0.0 & 5.2 & 0.045 & 52.7 & 14.1 & 69.5 & 15.4 & 4.4 \\
\hline Moores Creek & 0.0 & 0.81 & 0.271 & 30.9 & 37.0 & 57.0 & 4.5 & 5.2 \\
\hline
\end{tabular}

${ }^{1}$ Wastewater-treatment plant located upstream from site.

Macroalgae percent cover was strongly correlated only with bed substrate size (rho $=0.89$ ), canopy closure (rho $=-0.54)$, and specific conductance (rho=0.52) (table 9). Specific conductance probably was affected by the WWTP effluent. Macroalgae percent cover was not strongly correlated with nutrient concentrations or with land use. Despite the lack of strong correlations, total phosphorus (means of 0.19 and $0.06 \mathrm{mg} / \mathrm{L}$ associated with upstream WWTP and no upstream plant, respectively) and nitrate (means of 3.78 and $2.10 \mathrm{mg} / \mathrm{L}$ associated with upstream WWTP and no upstream plant, respectively) concentrations in streams downstream from WWTPs were considerably higher than concentrations at sites that did not have an upstream WWTP (fig. 3, table 8). 
Table 9. Correlations between macroalgae percent cover and selected environmental factors in the Illinois River Basin study area.

[Red font denotes absolute value of rho is greater than or equal to 0.50 ; number of sites equals 18]

\begin{tabular}{lc}
\hline & rho \\
\hline Nitrite plus nitrate & 0.22 \\
Total phosphorus & 0.32 \\
Temperature & 0.01 \\
Specific conductance & 0.52 \\
Dissolved oxygen & 0.39 \\
pH & 0.20 \\
Streamflow & 0.33 \\
Bankfull width & 0.16 \\
Drainage area & -0.08 \\
Bankfull width/drainage area & -0.05 \\
Depth & -0.21 \\
Velocity & 0.15 \\
Bed substrate & 0.89 \\
Embeddedness & -0.12 \\
Substrate turbidity & -0.33 \\
Open canopy angle & 0.49 \\
Combined canopy closure & -0.54 \\
Bank height & 0.09 \\
Bank angle & 0.00 \\
Poultry house density & -0.31 \\
Percent agriculture & -0.28 \\
Percent urban & 0.18 \\
Percent forest & -0.05 \\
Total unpaved road density & -0.35 \\
\hline & 0.21 \\
\hline & 0.12 \\
\hline
\end{tabular}

\section{Periphyton Communities}

Periphyton communities in Illinois River Basin streams almost always were dominated (highest biovolume) by diatoms or blue-green algae (also commonly referred to as "cyanobacteria") (tables 10-11, at the end of the report). Total, diatom, and blue-green algae biovolumes at the Illinois River Basin sites generally were somewhat greater than typical reported biovolumes from sites with a wide range of land uses and basin size in the Ozarks (Petersen and Femmer, 2003). However, percentages of total biovolume composed of diatoms and blue-green algae were similar to those reported by Petersen and Femmer (2003). Green algae were more dominant than diatoms and blue-green algae in two of the Illinois River Basin communities. The highest green algae biovolume occurred in a sample from Ballard Creek, where approximately 97 percent of the biovolume of the sample was composed of a single green algae genus (Pediastrum).

At the genus and species level, the Illinois River Basin periphyton communities differ substantially from communities sampled previously by USGS in the Ozarks (Petersen and Femmer, 2003; Justus and others, 2010). Taxa that often were among the most dominant taxa (highest biovolumes) at the Illinois River sites were Gloeocapsopsis (nutrient affinity not described - nutrient and trophic information in following parentheses from Porter, 2008), Phormidium (affinity for high phosphorus concentrations), Psammothidium curtissimum (affinity for low organic nitrogen, low nutrient concentrations), Cocconeis placentula (generally indicative of high nutrient concentrations), Nitzschia amphibia (generally indicative of high nutrient concentrations, nitrogen heterotroph with affinity for high organic nitrogen concentrations), Achnanthidium rivulare (generally indicative of low nutrient concentrations), and Heteroleibleinia (nutrient affinity not described). Gloeocapsopsis, Heteroleibleinia, Phormidium, Psammothidium curtissimum, and Achnanthium rivulare were completely absent from samples collected in the study described in Petersen and Femmer (2003). Conversely, the diatom Cymbella delicatula and the blue-green alga Calothrix, two common taxa found in many Ozark streams (Petersen and Femmer, 2003; Justus and others, 2010) were found at 0 and 1 of the 18 Illinois River Basin sites, respectively. Cymbella delicatula previously has been associated with low-nutrient streams, whereas Calothrix is an abundant and nearly ubiquitous blue-green algal taxon (Petersen and Femmer, 2003). 


\section{Relations Between Periphyton Communities and Land Use, Stream Habitat, and Water-Quality Factors}

Biomass of periphyton frequently is of interest to water-resources managers and the public because nuisance growths of attached algae provide visible evidence of nutrient enrichment (eutrophication) and water-quality degradation (Petersen and Femmer, 2003). Total biovolume, which is a surrogate for algal biomass, was not strongly correlated with any of the land use, stream-habitat, or water-quality factors assessed in the present study (table 12, at the end of the report). The absence of strong correlations corroborates results from Petersen and Femmer (2003), who reported that embeddedness $(\mathrm{p}=0.040)$ and alkalinity $(\mathrm{p}=0.079)$ were the only factors significantly correlated with total periphyton biovolume. Furthermore, there was little indication that total biovolume consistently was affected by the presence of an upstream WWTP. Although algal growth typically increases with higher nutrient concentrations and less shading, the standing crop of periphyton on rocks can be reduced by grazing by herbivorous macroinvertebrates and fish, which may explain why total biovolume in Ozark streams is not strongly affected by water-quality (or other habitat) factors (Petersen and Femmer, 2003).

Percent land use was not strongly correlated with biovolume or percent biovolume of blue-green algae, diatoms, or green algae (table 12). There was a moderately strong inverse correlation between percent agriculture and biovolume and percent biovolume of diatoms.
There were no strong correlations between total biovolume of blue-green algae, green algae, diatoms, Gloeocapsopsis, Phormidium, Heteroleibleinia, Nitzschia amphibia, and Cocconeis placentula and percent forest (fig. 4, table 12). Although the correlation between percent forest and the biovolume metrics was not strong, the highest total biovolume, diatom biovolume, and biovolumes of Phormidium, Cocconeis placentula, and Nitzschia amphibia occurred at sites with less than 50 percent forest (fig. 4).

The selected periphyton metrics listed in table 12 were most often and most strongly correlated with specific conductance, substrate turbidity, open canopy angle (a measure of riparian shading), percent agriculture, poultry house density, and unpaved road density; some of these factors were strongly correlated with percent forest, percent urban, or percent agriculture (table 5). Three strong or moderately strong correlations were detected between bluegreen algae biovolume and nitrate, blue-green algae percent biovolume and nitrate, and Nitzschia amphibia biovolume and total phosphorus. Comparisons of total biovolume with nutrients, embeddedness, bank height, and total road density generally did not indicate effects of these factors on total biovolume (fig. 5). Total biovolume did increase somewhat $($ rho $=0.45)$ as open canopy angle increased (fig. 5) and canopy closure decreased $(\mathrm{rho}=-0.46)$. The lack of correlation of total biovolume with nutrients and lack of a stronger correlation with canopy angle may be the result of periphyton grazing by herbivorous macroinvertebrates and fish. 

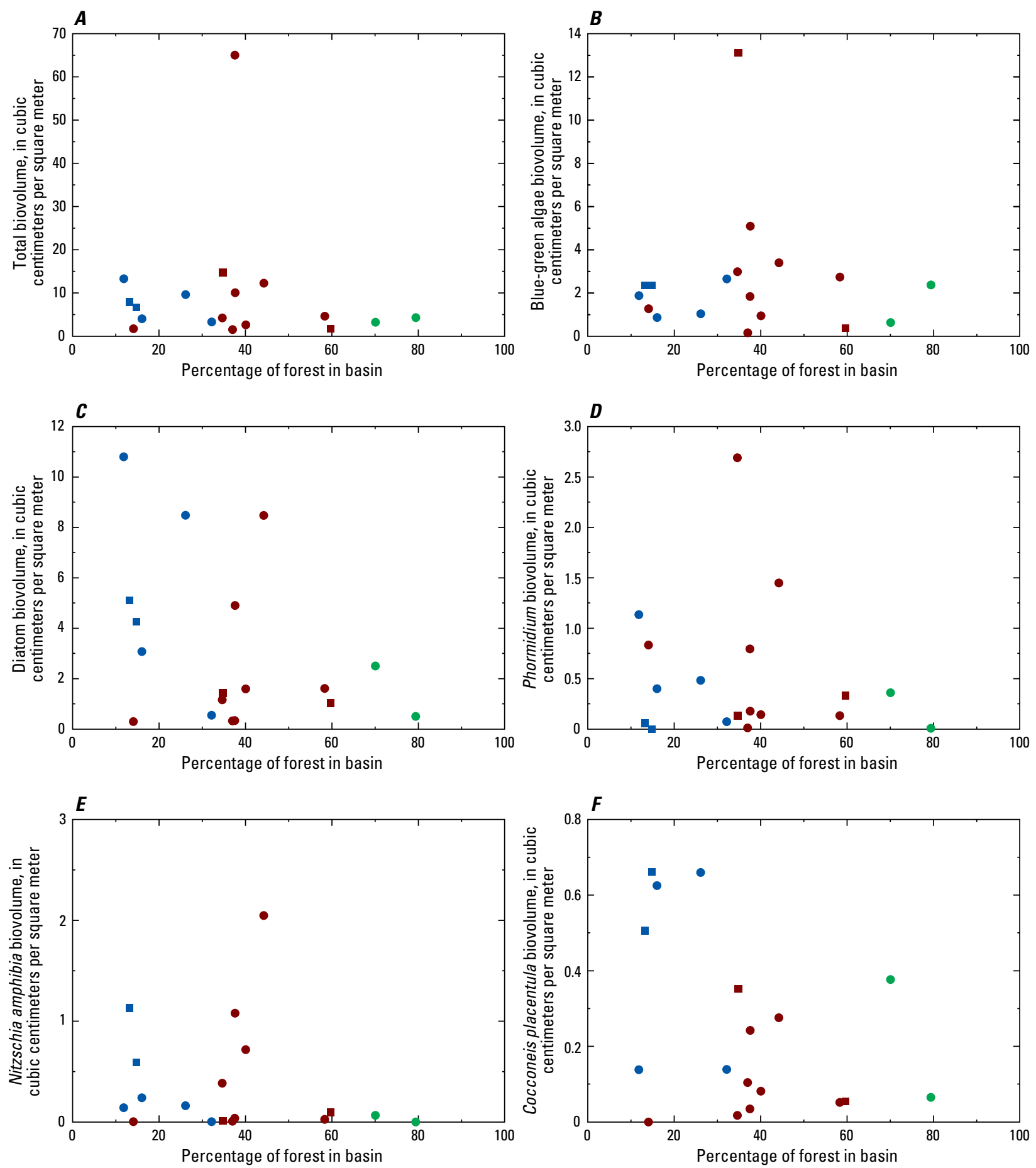

\section{EXPLANATION}

- Forest site

- Agriculture site

- Urban site

- Agriculture site with wastewater-treatment plant

- Urban site with wastewater-treatment plant

Figure 4. Scatterplots showing relations between periphyton metrics and percent forest in the Illinois River Basin study area. 

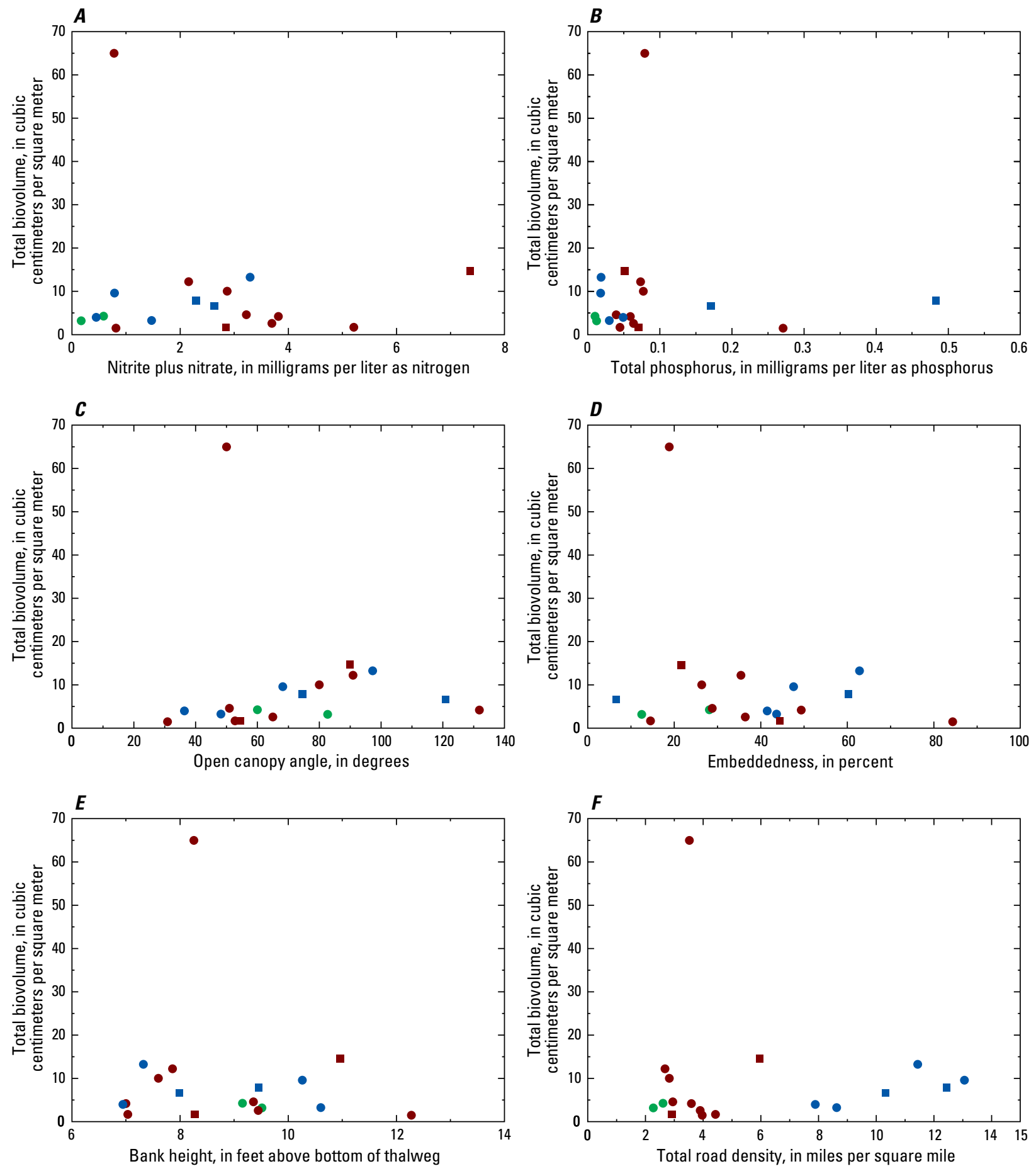

\section{EXPLANATION}

- Forest site

- Agriculture site

- Urban site

- Agriculture site with wastewater-treatment plant

- Urban site with wastewater-treatment plant

Figure 5. Scatterplots showing relations between periphyton total biovolume and selected environmental factors in the Illinois River Basin study area. 


\section{Macroinvertebrate Communities}

The most common and abundant macroinvertebrate taxa were in the orders Diptera (true flies), Trichoptera (caddisflies), Ephemeroptera (mayflies), Plecoptera (stoneflies), and Coleoptera (beetles). Macroinvertebrate taxa richness (number of taxa) for the 18 study sites ranged from 31 to 73 (table 13, at the end of the report). Taxa collected at the most sites include they mayfly Baetis, the caddisfly Cheumatopsyche, the crayfish Orconectes, the true flies (both Chironomidae) Polypedilum flavum and Rheotanytarsus, and the beetle Psephenus herricki. One of the least common taxa was the scud Gammarus, collected only at Little Osage.

Similar to the Ozark Highlands fish index of biotic integrity (described in the "Relations Between Fish Communities and Land Use, Stream Habitat, and WaterQuality Factors" section), sites with the lowest (indicative of most-disturbed conditions) macroinvertebrate index scores generally were sites with higher percentages of urban land use (or urban land use and WWTPs) in their basins (table 1; table 14, at the end of the report). Scores for the macroinvertebrate index ranged from 13 at Osage Creek-Rogers to 86 at Fly Creek (table 14). There were four sites in the poor classification (13-35), six sites in the fair classification (40-49), four sites in the good classification (5966 ), and four sites in the least-impaired classification (81-86). The four sites with the lowest index scores were urban sites, two of which were downstream from WWTPs. The four sites with the highest index scores were sites with the highest percentages of forest in their basins; however, one of the sites is also downstream from a WWTP (Baron Fork, the site farthest downstream from its associated WWTP, table 1).

\section{Relations Between Macroinvertebrate Communities and Land Use, Stream Habitat, and Water-Quality Factors}

Relations between the macroinvertebrate community metrics and land use, stream habitat, and water-quality factors were evaluated using four groups of sites. The four groups are based on land-use information in table 1 . The analysis of the data from the group of 14 sites not downstream from WWTPs was intended to evaluate the strength of effects of the land-use and other environmental factors across that entire range of sites in small Illinois River Basin streams. Four sites are downstream from WWTPs, and analyses of data for these sites were intended to evaluate the unique effects of WWTP effluent on downstream water quality. There are 10 agriculture gradient sites and 6 urban gradient sites. The analyses of the data for the 10 agriculture gradient sites and the 6 urban gradient sites were performed to focus on the strength of the effects of the environmental factors at sites representing small streams affected primarily by agriculture or urban land use (and without the effects of WWTPs) in the Illinois River
Basin. The low number of sites in the agriculture and urban gradients limits the confidence in these evaluations.

The macroinvertebrate index and several macroinvertebrate metrics were adversely affected by increasing urban and agricultural land use and associated environmental factors. These include metrics associated with tolerance to habitat degradation, taxonomic groups, diversity, behavior preference, and feeding preference. Factors most commonly affecting these metrics include factors associated with water quality, stream geometry, sediment, land-use percentages, and road density. The macroinvertebrate index and, in many cases, macroinvertebrate metric values indicated urban sites were more disturbed than agriculture and forest sites. However, many of the sites in the urban gradient also have a relatively high percentage (typically about 20 to 30 percent) of agriculture land use in the associated basins. Consequently, the percent of forest land use in most of the urban gradient basins is less than 30 percent and biological responses of the macroinvertebrate communities at the urban gradient sites probably were the result of the combined effects of urban and agricultural land use. Upstream WWTPs may have affected some macroinvertebrate metrics but had little effect on other metrics.

Correlations were calculated between more than 100 metrics (table 15, at the end of the report) and the environmental factors at the 18 sites. Correlations for the 21 metrics strongly correlated with at least three environmental factors, 2 additional metrics included in the macroinvertebrate index, and the macroinvertebrate index are reported in tables 16-18, at the end of the report. The following discussions will be limited to discussions of the macroinvertebrate index and metrics listed in tables 16-18.

\section{Combined-Gradient Sites}

Analysis of relations to environmental factors for all sites except the four WWTP sites, which were not included because of the somewhat unique effects of WWTPs, indicated that macroinvertebrate metrics were affected by several environmental factors. Twenty-three macroinvertebrate metrics (several of which are probably correlated with each other) and the macroinvertebrate index were strongly correlated with one or more of 16 of the 26 environmental factors (table 16). There were no strong correlations with most water-quality factors, drainage area, bankfull width, substrate turbidity, canopy angle, and percent agriculture. The strongest correlations with the largest number of macroinvertebrate metrics were with percent forest, percent urban, and road densities; correlations between macroinvertebrate metrics and percent agriculture were generally weak. In general (based on the correlations), the macroinvertebrate index was higher at sites with greater percentages of forest in their basins, lower percentages of urban land in their basins, and lower paved road density. The correlations with depth and water velocity probably were partially affected by the sampling of the most forested sites during a period of relatively low streamflow. 


\section{Relations Between Selected Macroinvertebrate Metrics and Percent Forest}

The relations between the macroinvertebrate index and the five index metrics and percent forest were selected for further analysis. As a group, these metrics are associated with, and likely respond to, factors related to water quality, substrate quality, and riparian shading. The relation between the index and these metrics and percent forest (and indirectly the urban and agriculture site class) is analyzed and discussed using scatterplots (fig. 6).

In general, values for the macroinvertebrate index increased as percent forest increased $(\mathrm{rho}=0.86)$ (fig. 6, table 16); however, this is to be expected for the macroinvertebrate index and the associated metrics because correlation with percent forest was one of the criteria used for selecting metrics for the macroinvertebrate index. The four sites with the highest index values (the least-disturbed category) are sites with percent agriculture ranging from approximately 20 to 40 percent and less than 4 percent urban in the basin. The four sites with the lowest index values (the poor category) are sites with low percentages of forest in their basins.

The indication that urban land use may influence macroinvertebrates more than agriculture land use may be the result of the differences in the land-use proportions between the sites in the urban gradient and sites in the agriculture gradient. Most sites in the agriculture gradient are associated with basins with almost entirely forest and agriculture land use (fig. 2, table 1). However, many of the sites in the urban gradient also have a relatively high percentage (typically about 20 to 30 percent) of agriculture land use in the associated basins.

The relation between Margalef diversity and the percent forest in the basin was strong ( $\mathrm{rho}=0.82)$. Macroinvertebrate samples collected at urban sites were associated with lower percentages of forest and were generally less diverse than macroinvertebrate samples collected at agriculture sites. Margalef diversity was most variable at sites with approximately 40 percent forest, whereas four of the five sites with the highest diversity had more than 55 percent forest in the basin.

Measures related to Ephemeroptera, Plecoptera, and Trichoptera (EPT) taxa are perhaps among the most popular metrics used for macroinvertebrate indicators (Barbour and others, 1999), and EPT richness had a strong correlation to percent forest $(\mathrm{rho}=0.72)$ in the present study. The metric also varied a great deal across both land-use gradients. Two of the four sites with the fewest EPT taxa were downstream from WWTPs, whereas one of the sites with the highest number of EPT taxa was a forest site.

The percent predator richness (percent of total richness composed of predators) was strongly correlated with percent forest $(\mathrm{rho}=0.73)$. For the seven sites that had less than 10 percent predator taxa in the macroinvertebrate community, five sites had less than 20 percent forest in the basin and five were urban sites. The metric was variable for the agriculture sites, ranging from 9 to 29 percent where 35 to 45 percent of the basin was forest land use.

The percentage of gatherer-collectors was strongly inversely correlated with percent forest $(\mathrm{rho}=-0.50)$. Gatherercollector macroinvertebrate taxa have a wide range of feeding habits and specialized or generalist feeding taxa may predominate depending on the ecological conditions (Osborne and others, 1980). In the present study, the metric may be most associated with generalists that were more successful as ecological conditions declined. Five sites with more than 41 percent forest had less than 24 percent gatherer-collectors, whereas gatherer-collectors composed 35 to 45 percent of the community at four urban sites with less than 20 percent forest.

The percent Baetidae (a family of Ephemeroptera) was strongly inversely correlated with percent forest $(\mathrm{rho}=-0.52)$. Baetidae generally were less than about 10 percent of the macroinvertebrate community at sites where percent forest was more than about 50 percent (fig. 6) and was typically higher and more variable at sites with lower percentages of forest. The percent Baetidae generally increases with increasing nutrient concentrations in small Ozark streams (Justus and others, 2010). 

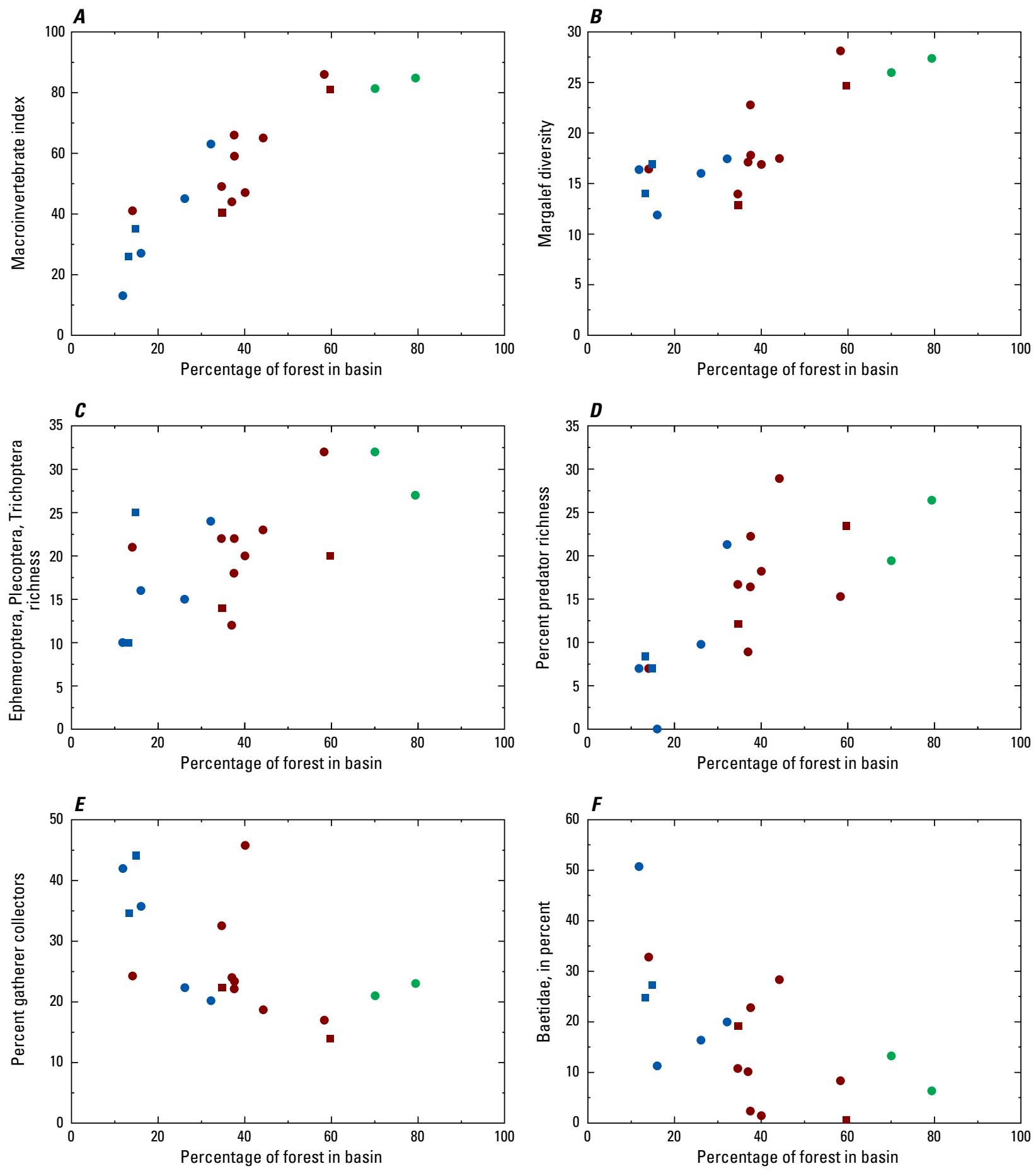

\section{EXPLANATION}

- Forest site

- Agriculture site

- Urban site

- Agriculture site with wastewater-treatment plant

- Urban site with wastewater-treatment plant

Figure 6. Scatterplots showing relations between percent forest, the macroinvertebrate index, and selected macroinvertebrate metrics in the Illinois River Basin study area. 


\section{Relations Between the Macroinvertebrate Index and Selected Environmental Factors}

The macroinvertebrate index was compared graphically to six environmental factors (two nutrients [nitrate and total phosphorus], a measure of substrate quality [embeddedness], a measure of riparian shading [open canopy angle], a measure of stream geometry [bank height], and total road density). Correlations with these six factors were moderate or strong for embeddedness, open canopy angle, bank height, and total road density (fig. 7, table 16). There were strong correlations between the index and about one-third of the 26 environmental factors (table 16); most of the strong correlations were with environmental factors directly related to land use or streamflow.

The macroinvertebrate index scores generally did not decrease with increasing nitrate concentrations (fig. 7), and the inverse correlation between the index and nitrate concentration is weak (rho $=-0.30)$ (table 16). Nitrate concentrations at the 18 sites ranged from 0.17 to $7.4 \mathrm{mg} / \mathrm{L}$; however, most urban sites had low macroinvertebrate index scores even at sites where nitrate concentrations were near the bottom of that range. When only the two forest sites and the eight agriculture sites without upstream WWTPs were considered for the agriculture gradient, correlations between the macroinvertebrate index and nitrate strengthened considerably $(\mathrm{rho}=-0.66$, table 17, at the end of the report). Correlations between the macroinvertebrate index and total phosphorus also were low ( $\mathrm{rho}=-0.16$, table 16). Highest index scores occurred at sites with total phosphorus concentrations less than $0.1 \mathrm{mg} / \mathrm{L}$, but many of the lowest index scores were associated with sites with total phosphorus concentrations less than $0.1 \mathrm{mg} / \mathrm{L}$. The high variability of index scores at sites where total phosphorus was less than $0.1 \mathrm{mg} / \mathrm{L}$ indicates that other environmental factors were more important than total phosphorus for determining macroinvertebrate index scores and macroinvertebrate community composition. Consistent with the fish index (see below), for both nitrate and phosphorus, macroinvertebrate index values almost always were lower at urban sites than at agriculture sites with similar nutrient concentrations.

Embeddedness was strongly inversely correlated with the macroinvertebrate index (rho $=-0.53$, table 16). The lowest index scores and the highest embeddedness generally occurred at sites with the highest percentages of urban land use (fig. 7). Open canopy angle was moderately correlated with the macroinvertebrate index $(\mathrm{rho}=-0.45$, table 16$)$ and index scores often were lower at urban sites than at agriculture sites with similar canopy angles. Bank height was moderately correlated with the macroinvertebrate index ( $\mathrm{rho}=0.44$, table 16). In general, for a given range of bank heights, index scores were lower at urban gradient sites than at agriculture gradient sites. Bank height may be an indication of channel incision.

Higher total road density was strongly correlated with lower macroinvertebrate index scores (rho $=-0.77$, table 16). Index scores decreased most substantially as road density increased from about 2 to $5 \mathrm{mi}$ per $\mathrm{mi}^{2}$ (fig. 7). Although variable, index scores generally decreased as road density increased from about 6 to $13 \mathrm{mi} \mathrm{per} \mathrm{mi}^{2}$. Highest total road densities and lowest index scores were associated with urban gradient sites.

\section{Agriculture Gradient Sites}

Analysis of data for the 10 agriculture gradient sites indicated that macroinvertebrate metrics were affected by several factors. Twenty-one macroinvertebrate metrics and the macroinvertebrate index were strongly correlated with one or more of 21 of the 26 factors (table 17). The environmental factors included measures of water quality, streamflow, water velocity, channel geometry, substrate quality, riparian shading, percent agriculture, percent forest, percent urban, and road densities. The strongest correlations with the largest number of macroinvertebrate metrics were with percent agriculture, percent forest, percent urban, streamflow, and total road density.

The macroinvertebrate index was strongly correlated with percent agricultural land use $(\mathrm{rho}=-0.83)$ and several other environmental factors for the 10 agriculture gradient sites; several of the metrics used to calculate the index also were strongly correlated with percent agriculture and other environmental factors (table 17). Most of these factors were related to land use, substrate quality, channel geometry, and road density. In general (based on the correlations), the macroinvertebrate index was higher at sites with higher percentages of forest in their basins (percent forest was a major criteria for selecting metrics used in the index), lower percentages of agricultural land in their basins, lower percentages of urban land in their basins, lower nutrient concentrations, wider bankfull widths, shallower depths, lower streamflow and water velocity, larger substrate size, and lower road density. The correlations with streamflow, depth, and velocity may result from sampling sites with highest percentages of forest in their associated basins during a period of relatively low streamflow.

\section{Urban Gradient Sites}

In general, macroinvertebrate index and macroinvertebrate metric values at urban gradient sites were more indicative of disturbed communities than values at agriculture gradient sites (figs. 6-7, table 14, table 1). The lowest index scores and several of the lowest Margalef diversity scores were at urban sites. Moreover, urban sites tended to have lower index scores for a given range of nutrient concentrations, lower index scores for a given range of canopy angles and a given range of bank heights, higher percentages of gatherer-collectors, lower values of EPT richness, and lower percent predator richness (figs. 6-7). This apparently larger effect of urban factors on the macroinvertebrate index may partly be the result of the differences in land-use proportions (substantially lower percentages of forest at urban gradient sites, fig. 2) between sites in the urban gradient and sites in the agriculture gradient. 

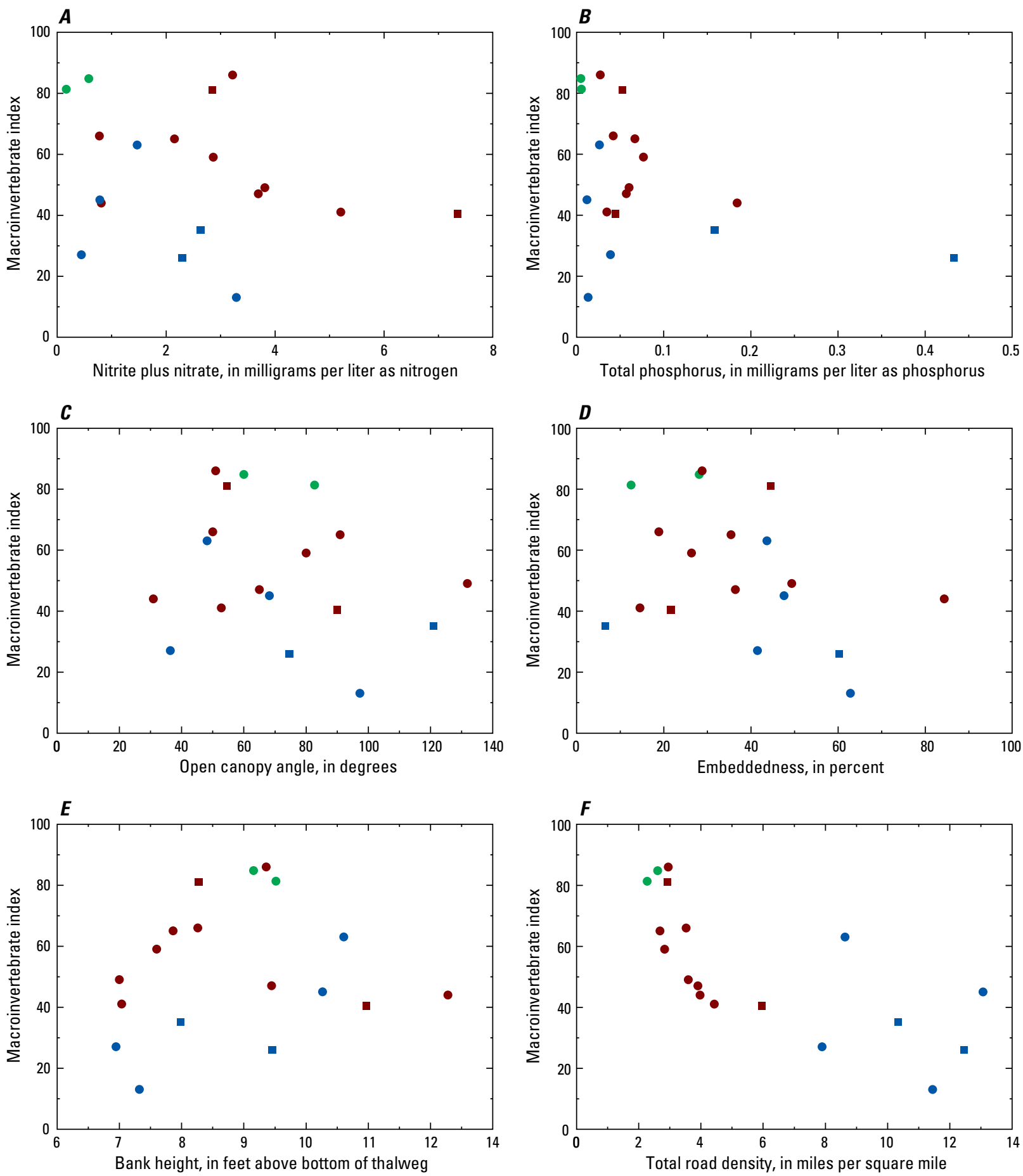

EXPLANATION

- Forest site

- Agriculture site

- Urban site

- Agriculture site with wastewater-treatment plant

- Urban site with wastewater-treatment plant

Figure 7. Scatterplots showing relations between the macroinvertebrate index and selected environmental factors in the Illinois River Basin study area. 
Analysis of data for the six urban gradient sites indicated that macroinvertebrate metrics were affected by several factors. Twenty-one macroinvertebrate metrics and the macroinvertebrate index were strongly correlated with one or more of 17 of the 26 environmental factors (table 18). The environmental factors included measures of land use, water quality, channel geometry, riparian shading, substrate quality, and road density. The macroinvertebrate index and most macroinvertebrate metrics were strongly or moderately correlated with percent urban and percent forest. The index and nearly two-thirds of the metrics were strongly or moderately correlated with total and paved road density.

The macroinvertebrate index was strongly and inversely correlated with percent urban land use (rho $=-0.94)$ and several other environmental factors for these six sites; several of the metrics used to calculate the index also were strongly correlated with percent urban and other environmental factors (table 18). Most of these factors were related to water quality, land use, and road densities. In general, the macroinvertebrate index was higher at sites with higher percentages of forest in their basins (percent forest was a major criteria for selecting metrics used in the index), lower percentages of urban land in their basins, lower nutrient concentrations, lower specific conductance, wider bankfull widths, shallower depths, lower streamflows, lower water velocities, larger substrate size, less embeddedness, higher bank angles, and lower road density. The correlations with streamflow, depth, and velocity probably were partly affected by the sampling of the most forested sites during a period of lower streamflow. Macroinvertebrate index scores generally were lower at urban sites than at agriculture sites. Scores often were lower at urban sites than at agriculture sites for a given range of environmental factors.

\section{Wastewater-Treatment Plant Sites}

Upstream WWTPs affected several metrics (figs. 6-7). For example, three of the five lowest macroinvertebrate index scores, two of the five lowest percent predator values, and two of the five highest percent gatherer-collector values were at sites downstream from WWTPs. For given values of embeddedness, canopy angle, and bank height, sites downstream from WWTPs tended to have lower macroinvertebrate index values than other sites. Also, macroinvertebrate index values at the two urban WWTP sites tended to be lower than values at sites with similar concentrations of nitrate. The sum of these results may indicate that some component of the effluent, other than nutrients, may have an effect on the macroinvertebrate communities.

\section{Fish Communities}

As for most Ozark streams, fish communities typically were dominated by the minnow, darter, and sunfish taxa (table 19, at the end of the report). Suckers were relatively infrequently collected. The most common fish collected were stoneroller (presumably two species), cardinal shiner, orangethroat darter, and slender madtom. The rarest fish were brook silverside, black bullhead, golden redhorse, golden shiner, redear sunfish, striped shiner, and white crappie. No common carp were collected. Species richness ranged from 14 in Clear Creek and Spring Creek to 28 in Fly Creek.

Scores for the Ozark Highlands fish index of biotic integrity (Dauwalter and others, 2003) (table 20, at the end of the report) ranged from 36 (Spring Creek) to 89 (Cincinnati Creek) (table 21, at the end of the report). Based on these scores, the sites were classified (Dauwalter and others, 2003) as poor (less than 40), fair (40 to less than 60), good (60 to less than 80 ), and reference ( 80 to 100 ; the reference class will be referred to herein as "least disturbed"). Lowest scores (in the poor or fair classes) were associated with sites with higher percentages of urban land use (or urban land use and WWTPs) in their basins. Most of the highest scores (that is, those in the least disturbed class) were associated with sites with some of the highest percentages of agriculture land use in their basins. Scores associated with the two sites with the highest percentages of forest land use in their basins (Evansville Creek and Illinois River) were lower than scores associated with many of the agriculture sites. Low streamflows (including the two lowest streamflows in the study) that occurred during the sampling of Evansville Creek and Illinois River may have lowered the fish index of biotic integrity scores of those two sites.

\section{Relations Between Fish Communities and Land Use, Stream Habitat, and Water-Quality Factors}

The relations between fish communities and land use, stream habitat, and water-quality factors were evaluated using four groups of data (the 14 sites that were not downstream from a WWTP, the 4 WWTP sites, the 10 agriculture gradient sites, and the 6 urban gradient sites). The low number of sites in the agriculture and urban gradients somewhat limits the confidence in these evaluations.

The results indicate that the Ozark Highlands fish index of biotic integrity and several fish metrics associated with feeding preference, spawning preference, and tolerance to habitat degradation were adversely affected by increasing urban and agricultural land use and associated factors. Factors affecting these metrics included factors associated with nutrients, sediment, and riparian shading. The Ozark Highlands fish index of biotic integrity and several fish metrics were most indicative of some disturbance of the fish community at urban sites. However, many of the sites in the urban gradient also have a relatively high percentage (typically about 20 to 30 percent) of agriculture land use in the associated basins. Consequently, the percent of forest land use in most of the urban gradient basins is less than 30 percent and biological responses of the fish communities at the urban gradient sites probably were the result of the combined effects of urban and agricultural land use. Upstream WWTPs seem to have affected some fish metrics while having little effect on other metrics. 


\section{Combined Gradient Sites}

Fish metrics were affected by several environmental factors at the 14 sites not downstream from WWTPs. Fifteen fish metrics and the index of biotic integrity were strongly correlated with one or more of 24 of the 26 environmental factors (table 22, at the end of the report). The fish metrics included measures of feeding preference, spawning preference, tolerance to habitat degradation, taxonomic relative abundance, and the Ozark Highlands fish index of biotic integrity. The environmental factors included measures of water quality, streamflow, channel geometry, substrate quality, riparian shading, basin land use (forest, agriculture, urban), density of poultry houses, and road density. In general (based on the correlations), the fish index of biotic integrity was higher at sites with higher percentages of forest in their basins, lower percentages of urban land in their basins, higher unpaved road density, and lower paved and total road density.

\section{Relations Between Fish Index of Biotic Integrity, Selected Fish Metrics, and Percent Forest}

The associations between the Ozark Highlands fish index of biotic integrity and five metrics and percent forest were selected for additional analysis and discussion. The metrics include three metrics included in the calculation of the fish index, or very similar to metrics included in the fish index (percent darter plus madtom plus sculpin individuals, number of lithophilic spawner species, and percent invertivore individuals), one metric related to tolerance of habitat degradation (percent tolerant individuals), and one metric (percent smallmouth bass individuals) that is related to a fish index metric and likely is important to a relatively large percentage of the general public because of its recreational fishing and economic importance. As a group, these metrics are associated with, and likely respond to, factors related to water quality, substrate quality, and riparian shading. The relation between the fish index and these metrics and percent forest (and indirectly the urban and agriculture site class) is analyzed and discussed using scatterplots (fig. 8).

In general, values for the Ozark Highlands fish index of biotic integrity increased as percent forest increased (rho=0.61) (fig. 8, table 22). The five sites with the highest index values (in the least-disturbed class) are sites with percent agriculture ranging from approximately 37 to 61 percent and less than 5 percent urban in the basin (table 1). The five sites with the lowest index values are sites in the urban gradient or an urban site with an upstream WWTP.
This apparent effect of urban land use and associated activities on the fish index may partly be the result of the differences in the land-use proportions between the sites in the urban gradient and sites in the agriculture gradient. Most sites in the agriculture gradient (agriculture sites without upstream wastewater-treatment plants plus forest sites) are in basins with almost entirely forest and agriculture land use (fig. 2, table 1). However, many of the sites in the urban gradient (urban sites without upstream wastewater-treatment plants plus forest sites) also have a relatively high percentage (typically about 20 to 30 percent) of agriculture land use in the associated basins.

The relative abundance of darter plus madtom plus sculpin individuals had a strong inverse correlation with percent forest (rho $=-0.54$ ) (fig. 8, table 22). Two of the lowest relative abundances occurred at the two sites with the highest percent of forest in their associated basins. The lithophilic spawners richness generally increased as percent forest increased (rho=0.85) (fig. 8). However, many of the largest numbers of lithophilic spawner species (12 to 14) occurred at agriculture sites with about 40 to 60 percent forest. The smallest number of lithophilic spawner species (six) occurred at urban sites with less than 20 percent forest.

The relative abundance of invertivores was not correlated with percent forest (rho $=-0.11$ ) (fig. 8), and variability was high when percent forest was less than approximately 40 percent. The lowest relative abundance (less than 10 percent) occurred at urban sites with less than 20 percent forest. Relative abundance of invertivores exceeded 30 percent at the two sites with more than approximately 70 percent forest. The variability consistently decreased, and the minimum percent invertivores for a given range of percent forest increased as percent forest increased (fig. 8).

Relative abundance of tolerant individuals did not change substantially with percent forest ( $\mathrm{rho}=-0.15$ ) (fig. 8). The lowest relative abundances of tolerant individuals occurred at a number of agriculture sites with forest land-use percentages of approximately 30 to 50 percent.

Relative abundance of smallmouth bass was strongly correlated with percent forest $(\mathrm{rho}=0.67)$. Smallmouth bass were not collected at six sites. Four of the six sites were urban sites (fig. 8) with greater than 35 percent urban land use in the basin. The four sites with the highest relative abundances of smallmouth bass were agriculture sites with approximately 40 percent forest. Two of the four urban sites where no smallmouth bass were collected had drainages areas of less than $14 \mathrm{mi}^{2}$; the other two urban sites had drainage areas of 16.0 and $22.8 \mathrm{mi}^{2}$. 

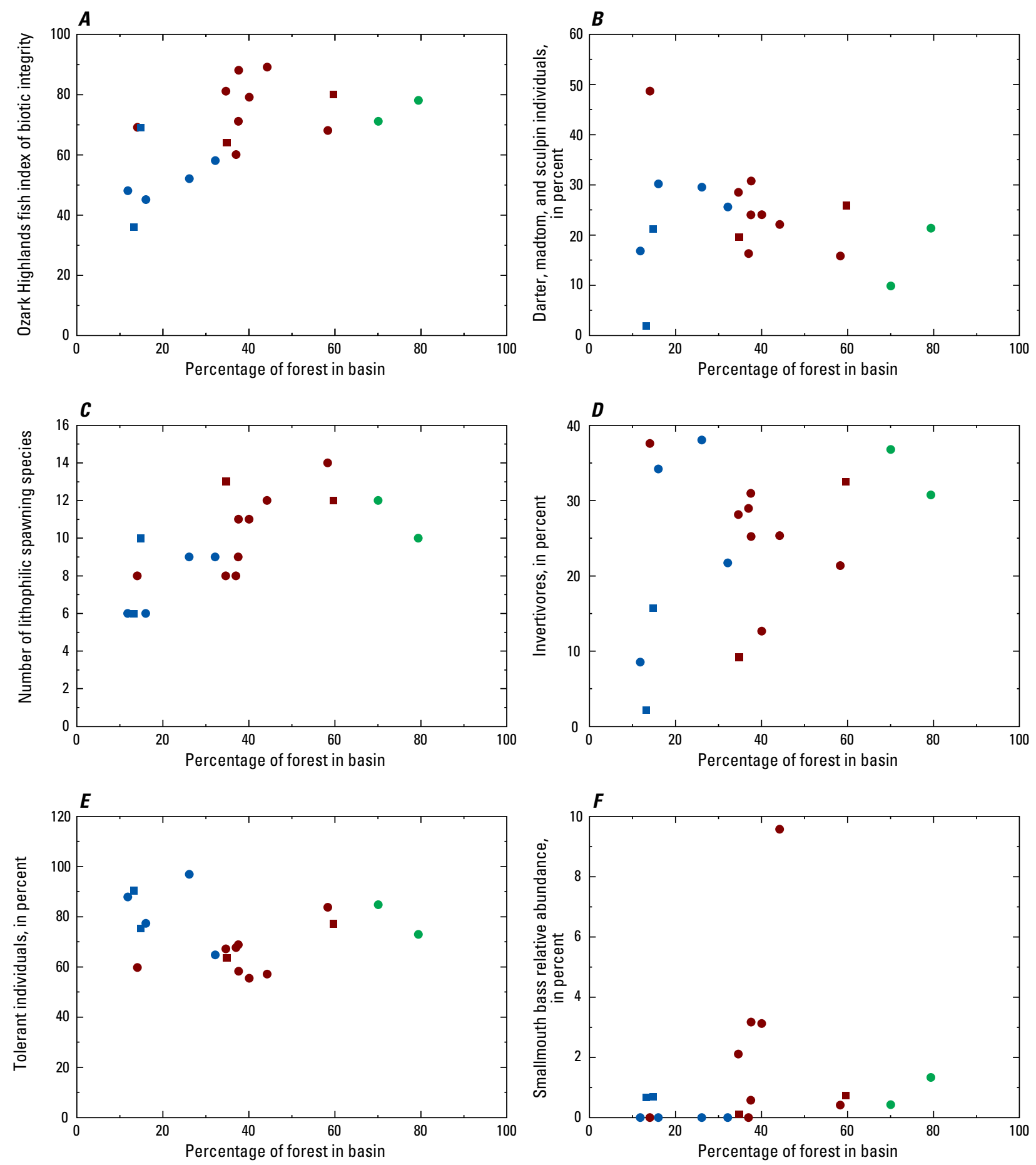

\section{EXPLANATION}

- Forest site

- Agriculture site

- Urban site

- Agriculture site with wastewater-treatment plant

- Urban site with wastewater-treatment plant

Figure 8. Scatterplots showing relations between percent forest in basin and the Ozark Highlands fish index of biotic integrity and selected fish metrics in the Illinois River Basin study area. 


\section{Relations Between the Fish Index and Selected Environmental Factors}

The Ozark Highlands fish index of biotic integrity also was compared graphically to six environmental factors using scatterplots (fig. 9). These factors include two nutrients, a measure of substrate quality, a measure of riparian shading, a measure of stream geometry, and a measure of road density. Correlations with these six factors were moderate or strong for embeddedness, open canopy angle, bank height, and total road density (fig. 9, table 22). Of the 26 environmental factors, there was a strong correlation only between the fish index and five environmental factors (percent forest, percent urban, and three measures of road density; table 22).

Correlations between nutrient concentrations and the Ozark Highlands fish index of biotic integrity were weak (nitrate, rho $=0.26$; total phosphorus, rho=0.37) (fig. 9, table 22). For both nutrients, fish index values almost always were lower at urban sites than at agriculture sites with similar nutrient concentrations. Embeddedness was moderately correlated with the fish index (rho=-0.41) (fig. 9). The lowest fish index values and the highest embeddedness generally occurred at sites with the highest percentages of urban land use. Increases in open canopy angle were moderately correlated with increases in the fish index value $(\mathrm{rho}=0.46)$ (fig. 9). Fish index values almost always were lower at urban sites than at agriculture sites with similar canopy angles. Bank height was not correlated with the fish index $(\mathrm{rho}=0.36)$ (fig. 9). In general, for a given range of bank heights, fish index values were lower at urban sites (urban sites without upstream wastewater-treatment plants plus forest sites) than at agriculture sites (agriculture sites without upstream wastewater-treatment plants plus forest sites). Total road density was strongly and inversely correlated with the fish index (rho=-0.74) (fig. 9). Although there was variability throughout the range of total road density, fish index values decreased with increasing road density. Highest road densities were associated with urban sites.

\section{Agriculture Gradient Sites}

Analysis of data for the 10 agriculture gradient sites indicated that fish metrics were affected by several factors. Seventeen fish metrics and the Ozark Highlands fish index of biotic integrity were strongly correlated with one or more of 21 of the 26 environmental factors (table 23, at the end of the report). The fish metrics included measures of density, feeding preference, spawning preference, tolerance to habitat degradation, taxonomic relative abundance and richness, and the fish index. The environmental factors included measures of land use, road density, water quality, channel geometry, riparian shading, bed sediment quality, water velocity, and stream size. The fish index was strongly correlated only with open canopy angle, but in general (based on the stronger correlations) the fish index of biotic integrity was higher at sites with less shading, smaller drainage areas, and lower substrate turbidity.

Although there was no correlation $(\mathrm{rho}=0.02)$ between the Ozark Highlands fish index of biotic integrity and percent agriculture land use for the 10 agriculture gradient sites, the fish index and metrics used to calculate the index were moderately to strongly correlated with several other factors (table 23); few factors were strongly correlated with more than one of the metrics that are part of the fish index. Most of these factors were related to land use, substrate quality, channel geometry, and riparian shading. For example the number of lithophilic spawning species was strongly correlated with percent agriculture and the fish index was strongly correlated with canopy angle.

Relations between selected fish metrics and percent forest for the agriculture gradient sites sometimes differed substantially from the same relations for the complete set of sampled sites (fig. 8). For example, there was an overall strong positive correlation between the fish index and forest land use ( $\mathrm{rho}=0.61$ ) for the set of 14 sites, but that correlation was much lower for agriculture gradient sites $(\mathrm{rho}=0.13)$. At most agriculture gradient sites, the relation between forest land use and the relative abundance of darters plus madtoms plus sculpins seemed to be much stronger than the same relation among all sites. In contrast with the set of 14 sites $($ rho $=0.67)$, relative abundance of smallmouth bass did not consistently increase with increasing percent forest $(\mathrm{rho}=0.25)$, and the highest relative abundances were associated with four agriculture gradient sites with percent forest values of approximately 35 to 45 percent.

\section{Urban Gradient Sites}

In general, Ozark Highlands fish index of biotic integrity and fish metric values at urban gradient (urban sites without upstream wastewater-treatment plants plus forest sites) sites were more indicative of disturbed communities than values at agriculture gradient sites (agriculture sites without upstream wastewater-treatment plants plus forest sites) (figs. 8-9, table 1, table 21). The lowest fish index scores were at urban gradient sites. In addition, urban gradient sites tended to have fewer lithophilic spawner species (richness), fewer smallmouth bass, and lower fish index values for a given range of nutrient concentrations (fig. 9). Lower fish index values occurred at sites with higher embeddedness and paved road densities, which are typical of urban sites (table 5). The indication that urban land use may influence fish more than agriculture land use may partly be the result of the differences in the land-use proportions (substantially lower percentages of forest at urban gradient sites, fig. 2) between the sites in the urban gradient and sites in the agriculture gradient. 

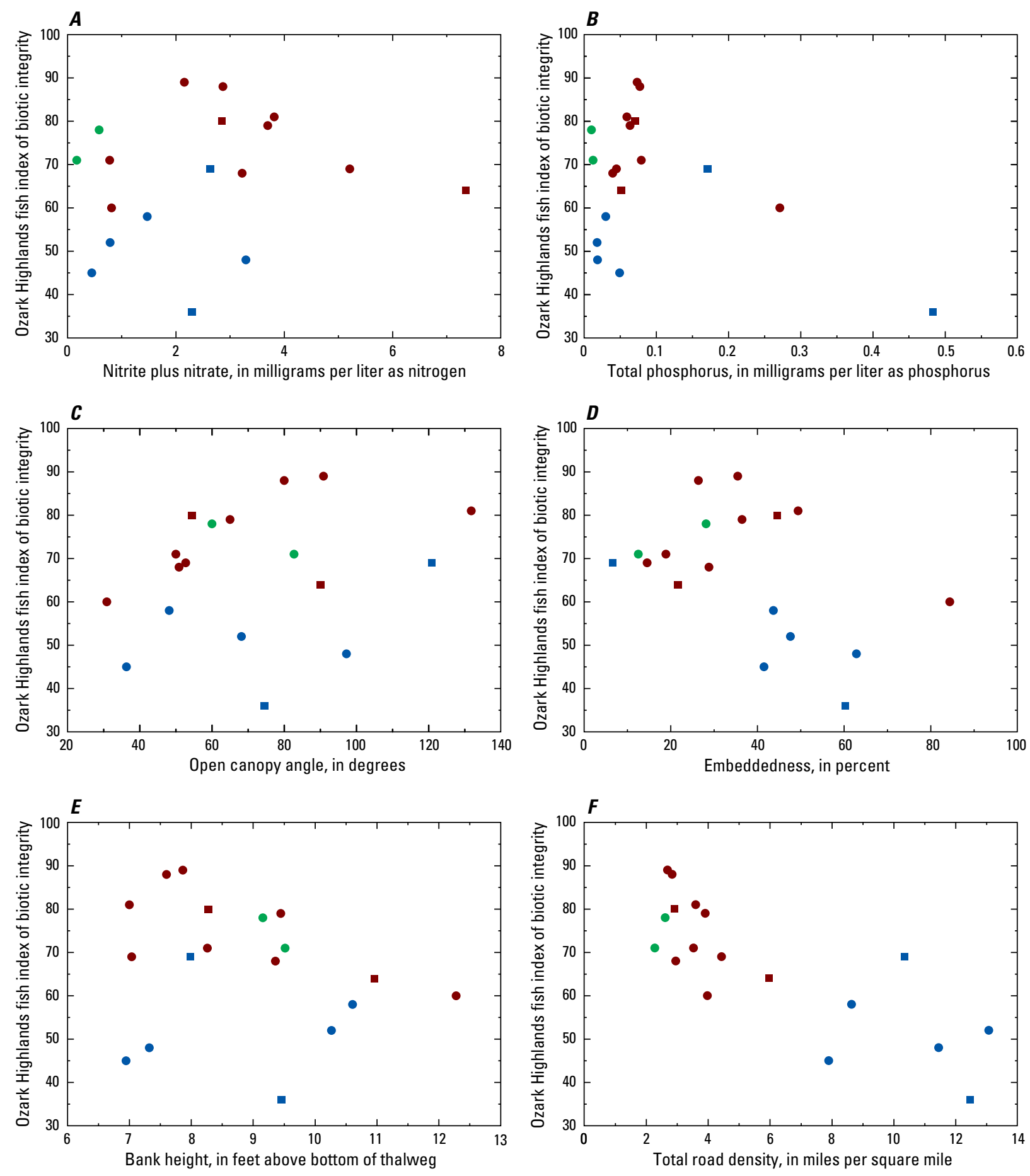

\section{EXPLANATION}

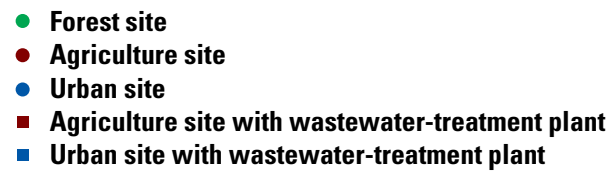

Figure 9. Relations between the Ozark Highlands fish index of biotic integrity and selected environmental factors in the Illinois River Basin study area. 
Analysis of data for the six urban gradient sites indicated that fish metrics were affected by several factors. Thirteen fish metrics and the fish index were strongly correlated with one or more of 22 of the 26 environmental factors (table 24, at the end of the report). The fish metrics included measures of feeding preference, spawning preference, taxonomic relative abundance and richness, and the Ozark Highlands fish index of biotic integrity. The environmental factors included measures of land use, road density, water quality, channel geometry, riparian shading, substrate quality, water velocity, and streamflow. In general (based on the correlations), the fish index was higher at sites with higher percentages of forest in their basins, lower percentages of urban land in their basins, lower nutrient concentrations, shallower depths, lower streamflows, and lower velocities. The correlations with streamflow, depth, and velocity may be affected by the sampling of the sites with the highest percentages of forest during a period of relatively low streamflow.

There was a strong inverse correlation ( $\mathrm{rho}=-0.83$ ) between the fish index and percent urban land use for these six sites; the fish index and metrics used to calculate the index were strongly correlated with several other factors (table 24). Most of these factors were related to land use, water quality, streamflow, channel geometry, and riparian shading. For example, the relative abundance of top carnivores, species richness of lithophilic spawners, and the fish index were negatively correlated with total phosphorus.

\section{Wastewater-Treatment Plant Sites}

Upstream WWTPs appear to have substantially affected some fish community metrics but had little effect on other metrics (figs. 8-9, table 21). For example, three of the five lowest relative abundances of lithophilic spawner minus stonerollers and four of the five highest stoneroller relative abundances were at sites downstream from WWTPs. The relative abundance of darters plus madtoms plus sculpins at one site (Spring Creek) was substantially lower than at any other site, and the number of darter plus madtom plus sculpin species tended to be somewhat lower for a given percentage of forest at these sites. An unusually high relative abundance of yellow bullheads (a tolerant species) occurred at Spring Creek (table 19). However, the fish index, relative abundance of tolerant fish species, relative abundance of invertivores, and relative abundance of smallmouth bass do not appear to be strongly influenced by the upstream WWTPs.

\section{Limitations and Implications}

Interpretations of the results of the study are limited by a number of factors. These include the drought that occurred during the sampling period, the necessity to sample some of the sites in 2012 because of low streamflows in 2011, the absence of sites of appropriate drainage area with percent forest exceeding 80 percent (limited to leastdisturbed sites rather than "reference" sites), the large number of environmental settings (which are determined by the interaction of land use, land-use intensity, instream and riparian habitat quality, and groundwater influence), rapid land-use changes in some parts of the Illinois River Basin, incomplete characterization of land-use intensity based on the available data, and the relatively low number of sites. These factors individually and collectively add to uncertainty and variability in the responses to various environmental stresses (including, but not limited to, nutrients, sediment, habitat degradation, and streamflow alteration). Notwithstanding the limiting factors, the biological responses of macroalgae cover and periphyton, macroinvertebrate, and fish metrics to environmental variables provide multiple lines of evidence that biological communities of these streams are being affected by recent and ongoing land-use practices.

Many types of land-use, water-quality, and habitat factors affected one or more aspects of the biological communities. For example, percent macroalgae cover uniformly was highest at the four sites downstream from WWTPs, but the strongest correlation among the 18 sites was to open canopy angle. Nitrate was moderately correlated with biovolume of blue-green algae periphyton and strongly correlated with percent biovolume of blue-green algae periphyton. Several macroinvertebrate and fish metrics change in response to changes in percent forest; sites that would be considered most disturbed, based on these metrics, are sites with the highest percentages of urban land use in their associated basins.

However, many of the sites in the urban gradient also have a relatively high percentage (typically about 20 to 30 percent) of agriculture land use in the associated basins. Consequently, the percent of forest land use in most of the urban gradient basins is less than 30 percent and biological responses of the fish communities at the urban gradient sites probably were the result of the combined effects of urban and agricultural land use. For some metrics (notably macroalgae cover, for example), sites downstream from WWTPs tended to have values indicative of more disturbed communities, but other metrics did not indicate disturbance.

For several biological metrics (for example, percent macroalgae cover; diatom biovolume; Phormidium biovolume; macroinvertebrate index; macroinvertebrate Margalef diversity; Ephemeroptera, Plecoptera, Trichoptera richness; percent macroinvertebrate gatherer-collectors; and relative abundance of smallmouth bass), there appears to be a threshold of about 40 to 50 percent forest where values of these metrics change in magnitude (figs. 3, 4, 6, and 8). However, the four sites with more than 50 percent forest in their basins were the four sites sampled in late May-early June of 2012. The relative influence of season and forest percentage on the biological communities at these sites is unknown. The high number of metrics that show this pattern is evidence that biological communities in small Illinois River Basin streams change where percent forest decreases to less than about 50 percent. 


\section{Summary}

The Illinois River Basin includes an area of diverse land use in northwestern Arkansas. Land-use data collected in 2006 indicate that most of the land in the basin is agricultural. From 1992 to 2006, there was a shift from agricultural land use to urban land use as the cities of Fayetteville, Springdale, and Rogers grew in area and in population. Forest plus herbaceous land use increased from 29 to 41 percent during the same period. The agricultural land is used primarily for production of poultry and cattle.

Eighteen sites were selected from the list of candidate sites based on drainage area, land use, presence or absence of an upstream WWTP, water quality, and other information gathered during the reconnaissance. An important consideration in the process was to select sites along gradients of forest to urban land use and forest to agricultural land use. Water-quality samples were collected for analysis of nutrients, and a multiparameter field meter was used to measure water temperature, specific conductance, $\mathrm{pH}$, and dissolved oxygen. Streamflow was measured immediately following the waterquality sampling. Periphyton, macroinvertebrate, and fish communities were sampled at each site. Stream habitat also was assessed.

Many types of land-use, water-quality, and habitat factors affected one or more aspects of the biological communities. Several macroinvertebrate and fish metrics change in response to changes in percent forest; sites that would be considered most disturbed, based on these metrics, are sites with the highest percentages of urban land use in their associated basins. However, many of the sites in the urban gradient also have a relatively high percentage (typically about 20 to 30 percent) of agriculture land use in the associated basins. Consequently, the percent of forest land use in most of the urban gradient basins is less than 30 percent and biological responses of the macroinvertebrate communities at the urban gradient sites probably were the result of the combined effects of urban and agricultural land use.

The presence of large mats of macroalgae (the algae with visible structure, rather than the typically microscopic algal structure of periphyton) was one of the most noticeable biological characteristics in several streams within the Illinois River Basin. The highest macroalgae percent cover values were recorded at four sites downstream from wastewatertreatment plants. Macroalgae percent cover was strongly correlated only with bed substrate size, canopy closure, and specific conductance.

Total biovolume of periphyton, which is a surrogate for algal biomass, was not strongly correlated with any of the land-use, habitat, or water-quality factors assessed in the present study. Although algal growth typically increases with higher nutrient concentrations and less shading, the standing crop of periphyton on rocks can be reduced by grazing by herbivorous macroinvertebrates and fish, which may explain why total biovolume in Ozark streams is not strongly affected by water-quality (or other habitat) factors. Other periphyton metrics were most often and most strongly correlated with riparian shading, specific conductance, substrate turbidity, percent agriculture, poultry house density, and unpaved road density; some of these factors are strongly correlated with percent forest, percent urban, or percent agriculture. Three strong or moderately strong correlations were detected between blue-green algae biovolume and blue-green algae percent biovolume and nitrate, and Nitzschia amphibia biovolume and total phosphorus. Cymbella delicatula, a diatom associated with low-nutrient streams, was not found at any sites in the present study.

A macroinvertebrate index and several macroinvertebrate metrics were adversely affected by increasing urban and agricultural land use and associated environmental factors. These include metrics associated with tolerance to habitat degradation, taxonomic groups, diversity, behavior preference, and feeding preference. Factors most commonly affecting these metrics included factors associated with water quality, stream geometry, sediment, land-use percentages, and road density. Correlations with the macroinvertebrate index were moderate or strong for embeddedness, open canopy angle, bank height, total road density, and other factors. The macroinvertebrate index and, in many cases, macroinvertebrate metric values were most indicative of some disturbance of the macroinvertebrate community at urban sites. However, many of the sites in the urban gradient also have a relatively high percentage (typically about 20 to 30 percent) of agriculture land use in the associated basins. The four sites with the highest index scores (indicative of least disturbance) were sites with the highest percentages of forest in their basins; however, one of the sites is also downstream from a wastewater-treatment plant (the site farthest downstream from its associated wastewater-treatment plant). The four sites with the lowest index scores were urban sites, two of which were downstream from wastewater-treatment plants. In general (based on the correlations), the macroinvertebrate index was higher at sites with greater percentages of forest in their basins, lower percentages of urban land in their basins, and lower paved road density. The correlations with depth and water velocity probably are partially affected by the sampling of the most forested sites during a period of relatively low streamflow. Correlations with the macroinvertebrate index were moderate or strong (absolute value of rho greater than or equal to 0.40) for embeddedness, open canopy angle, bank height, total road density, and other factors. Upstream wastewater-treatment plants affect several metrics. For example, three of the five lowest macroinvertebrate index scores, two of the five lowest percent predator values, and two of the five highest percent gatherer-collector values are at sites downstream from wastewater-treatment plants.

The Ozark Highlands fish index of biotic integrity and several fish metrics associated with feeding preference, spawning preference, and tolerance to habitat degradation were adversely affected by increasing urban and agricultural land use and associated factors. Factors affecting these metrics include factors associated with nutrients, sediment, 
and riparian shading. Correlations with the fish index of biotic integrity were moderate or strong (absolute value of rho greater than or equal to 0.40 ) for total road density, embeddedness, open canopy angle, and other factors; correlations were weak for nitrate, total phosphorus, and bank height. The Ozark Highlands fish index of biotic integrity and several fish metrics were most indicative of some disturbance of the fish community at urban sites. However, many of the sites in the urban gradient also have a relatively high percentage (typically about 20 to 30 percent) of agriculture land use in the associated basins. Most of the highest scores (that is, those in the least-disturbed class) were associated with sites with some of the highest percentages of agriculture land use in their basins. Lowest scores (in the poor or fair classes) were associated with sites with high percentages of urban land use (or urban land use and wastewater-treatment plants) in their basins. In general (based on the correlations), the fish index of biotic integrity was higher at sites with higher percentages of forest in their basins, lower percentages of urban land in their basins, higher unpaved road density, and lower paved and total road density. Upstream wastewater-treatment plants appear to affect some fish community metrics substantially but have little effect on other metrics. For example, the relative abundance of darters plus madtoms plus sculpins at one site (Spring Creek) was substantially lower than at any other site. However, the fish index, relative abundance of tolerant individuals, relative abundance of invertivores, and relative abundance of smallmouth bass do not appear to be strongly influenced by the upstream WWTPs.For example, three of the five lowest relative abundances of lithophilic spawner minus stonerollers and four of the five highest stoneroller abundances were at sites downstream from wastewatertreatment plants.

Interpretations of the results of the study described in this report are limited by a number of factors. These factors individually and collectively add to uncertainty and variability in the responses to various environmental stresses (including, but not limited to, nutrients, sediment, habitat degradation, and streamflow alteration). Notwithstanding the limiting factors, the biological responses of macroalgae cover and periphyton, macroinvertebrate, and fish metrics to environmental variables provide multiple lines of evidence that biological communities of these streams are being affected by recent and ongoing land-use practices.

For several biological metrics, there appears to be a threshold of about 40 to 50 percent forest where values of these metrics change in magnitude. However, the four sites with more than 50 percent forest in their basins were the four sites sampled in late May-early June of 2012 (rather than July-August of 2011). The relative influence of season and forest percentage on the biological communities at these sites is unknown. The high number of metrics that show this pattern is evidence that biological communities in small Illinois River Basin streams change where percent forest decreases to less than about 50 percent.

\section{References Cited}

Adamski, J.C., Petersen, J.C., Freiwald, D.A., and Davis, J.V., 1995, Environmental and hydrologic setting of the Ozark Plateaus study unit, Arkansas, Kansas, Missouri, and Oklahoma: U.S. Geological Survey Water-Resources Investigations Report 94-4022, 69 p.

Arkansas Department of Environmental Quality, 1997, Illinois River water quality, macroinvertebrate, and fish community survey: Arkansas Department of Environmental Quality WQ-97-03-1, 158 p.

Arkansas Geographic Information Office, 2006, GeoStor, Arkansas' official GIS platform: Arkansas.gov, accessed March 2, 2011, at http://www.geostor.arkansas.gov/.

Arkansas Pollution Control and Ecology Commission, 2011, Regulation no. 2- Regulation establishing water quality standards for surface waters of the State of Arkansas: Arkansas Pollution Control and Ecology Commission \#014.00-002, 119 p.

Barbour, M.T., Gerritsen, J., Snyder, B.D. and Stribling, J.B., 1999, Rapid bioassessment protocols for use in streams and wadeable rivers - Periphyton, benthic macroinvertebrates, and fish: Washington, D.C., U.S. Environmental Protection Agency Office of Water EPA 841-B-99 002 [variously paged].

Bhattacharyya, G.K., and Johnson, R.A., 1977, Statistical concepts and methods: New York, John Wiley, 639 p.

Coles, J.F., McMahon, Gerard, Bell, A.H., Brown, L.R., Fitzpatrick, F.A., Scudder Eikenberry, B.C., Woodside, M.D., Cuffney, T.F., Bryant, W.L., Cappiella, Karen, FraleyMcNeal, Lisa, and Stack, W.P., 2012, Effects of urban development on stream ecosystems in nine metropolitan study areas across the United States: U.S. Geological Survey Circular 1373, 138 p.

Cuffney, T.F., and Brightbill, R.A., 2011, User's manual for the National Water-Quality Assessment Program Invertebrate Data Analysis System (IDAS) software, version 5: U.S. Geological Survey Techniques and Methods 7-C4, $126 \mathrm{p}$.

Davis, J.V., and Bell, R.W., 1998, Water-quality assessment of the Ozark Plateaus study unit, Arkansas, Kansas, Missouri, and Oklahoma-Analysis of information on nutrients, suspended sediment, and suspended solids, 1970-92: U.S. Geological Survey Water-Resources Investigations Report 95-4042, $112 \mathrm{p}$.

Dauwalter, D.C., Pert, E.J., and Keith, W.E., 2003, An index of biotic integrity for fish assemblages in Ozark Highland streams of Arkansas: Southeastern Naturalist: v. 2, no. 3, p. 447-468. 
Fishman, M.J., 1993, Methods of analysis by the U.S. Geological Survey National Water Quality LaboratoryDetermination of inorganic and organic constituents in water and fluvial sediments: U.S. Geological Survey OpenFile Report 93-125, $217 \mathrm{p}$.

Fitzpatrick, F.A., Waite, I.R., D’Arconte, P.J., Meador, M.R., Maupin, M.A., and Gurtz, M.A., 1998, Revised methods for characterizing stream habitat in the National Water-Quality Assessment Program: U.S. Geological Survey WaterResources Investigations Report 98-4052, 67 p.

FTN Associates, Ltd., 2012, Watershed-based management plan for the upper Illinois River watershed, northwest Arkansas, $206 \mathrm{p}$.

Helsel, D.R., and Hirsch, R.M., 2002, Statistical methods in water resources: U.S. Geological Survey Techniques of Water-Resources Investigations, book 4, chap. A3, 510 p.

Justus, B.G., 2003, An index of ecological integrity for the Mississippi Alluvial Plain ecoregion-Index development and relations to selected landscape variables: U.S. Geological Survey Water-Resources Investigations Report 2003-4110, $32 \mathrm{p}$.

Justus, B.G., Petersen, J.C., Femmer, S.R., Davis, J.V., and Wallace, J.E., 2010, A comparison of algal, macroinvertebrate, and fish assemblage indices for assessing low-level nutrient enrichment in wadeable Ozark streams: Ecological Indicators, accessed November 3, 2012 at http://dx.doi.org/10.1016/j.ecolind.2009.10.007.

Klemm, D.J, Lewis, P.A., Fulk, F., and Lazorchak, J.M., 1990, Macroinvertebrate field and laboratory methods for evaluating the biological integrity of surface waters: U.S. Environmental Protection Agency EPA/600/4-90/030, $256 \mathrm{p}$.

Margalef, R., 1958, Information theory in ecology: General Systematics, v. 3, p. 36-71.

Master, L.L., Flack, S.R., and Stein, B.A., eds., 1998, Rivers of life-Critical watershed for protecting freshwater biodiversity: Arlington, Virginia, The Nature Conservancy, $71 \mathrm{p}$.

McGoodwin, Williams, and Yates, Inc., 2009, Water quality and ecological assessment of Osage and Spring Creeks in the Illinois River Basin, Arkansas: Fayetteville, Arkansas, McGoodwin, Williams, and Yates, Inc., 106 p.

Moulton, S.R., II, Carter, J.L., Grotheer, S.A., Cuffney, T.F., and Short, T.M., 2002, Revised protocols for sampling algal, macroinvertebrate, and fish communities as part of the National Water-Quality Assessment Program: U.S. Geological Survey Open-File Report 02-150, 87 p.

National Climatic Data Center, 2013, Quality controlled local climatological data, accessed March 27, 2013, at http://cdo. ncdc.noaa.gov/qclcd/QCLCD.
Oklahoma Water Resources Board, 2013, Oklahoma's Water Quality Standards, accessed September 30, 2013 at http:// www.owrb.ok.gov/util/rules/pdf_rul/current/Ch45.pdf.

Osborne, L.L., Davies, R.W., and Linton, K.J., 1980, Use of hierarchical diversity indices in lotic community analysis: Journal of Applied Ecology, v. 17, 567-580

Parsons and the University of Arkansas, 2004, Final Report - Volume 1, Water quality and biological assessment of selected segments in the Illinois River Basin and Kings River Basin, Arkansas, miscellaneous pagination.

Paul, M.J., and Meyer, J.L., 2001, Streams in the urban landscape: Annual Review of Ecology and Systematics, v. 32, p. 333-365.

Patton, C.J., and Kryskalla, J.R., 2003, Methods of analysis by the U.S. Geological Survey National Water Quality Laboratory-Evaluation of alkaline persulfate digestion as an alternative to kjeldahl digestion for determination of total and dissolved nitrogen and phosphorus in water: U.S. Geological Survey Water-Resources Investigations Report 03-4174, 33 p.

Petersen, J.C., Adamski, J.C., Bell, R.W., Davis, J.V., Femmer, S.R., Freiwald, D.A., and Joseph, R.L., 1998, Water quality in the Ozark Plateaus, Arkansas, Kansas, Missouri, and Oklahoma, 1992-1995: U.S. Geological Survey Circular $1158,34 \mathrm{p}$.

Petersen, J.C., and Femmer, S.R., 2003, Periphyton communities in streams of the Ozark Plateaus and their relations to selected environmental factors: U.S. Geological Survey Water-Resources Investigations Report 02-4210, $77 \mathrm{p}$.

Petersen, J.C., Justus, B.G., Dodd, H.R., Bowles, D.E., Morrison, L.W., Williams, M.H., and Rowell, G.A., 2008, Methods for monitoring fish communities of Buffalo National River and Ozark National Scenic Riverways in the Ozark Plateaus of Arkansas and Missouri-Version 1: U.S. Geological Survey Open-File Report 2007-1302, 94 p.

Porter, S.D., 2008, Algal attributes-An autecological classification of algal taxa collected by the National WaterQuality Assessment Program: U.S. Geological Survey Data Series 329, accessed May 2009, at http://pubs.usgs.gov/ds/ ds $329 /$.

Stevenson, R.J., undated, Nutrient pollution of streams in the Illinois River watershed, Oklahoma-Effects on water quality, aesthetics, and biodiversity, accessed February 10, 2013, at http://www.owrb.ok.gov/quality/standards/pdf standards/scenicrivers/OK\%20Attorney\%20General $\% 20$ $-\% 20$ Stevenson\%20File.pdf.

U.S. Geological Survey, variously dated, National field manual for the collection of water-quality data: U.S. Geological Survey Techniques of Water-Resources Investigations, book 9, chaps. A1-A9, available online at http://pubs.water. usgs.gov/twri9A. 
U.S. Census Bureau, 2013a, Arkansas population of counties by decennial census: Washington, D.C., U.S. Bureau of the Census, accessed March 29, 2013, at http://census.gov/ population/cencounts/ar190090.txt.
U.S. Census Bureau, 2013b, State \& County QuickFacts: U.S. Census Bureau, accessed March 29, 2013, at http:// quickfacts.census.gov/qfd/states/05000.html. 
Table 10. List of algal taxa and biovolumes for sampling sites in the Illinois River Basin study area.

[Biovolume is in cubic centimeters per square meter, values are rounded to seven decimal places]

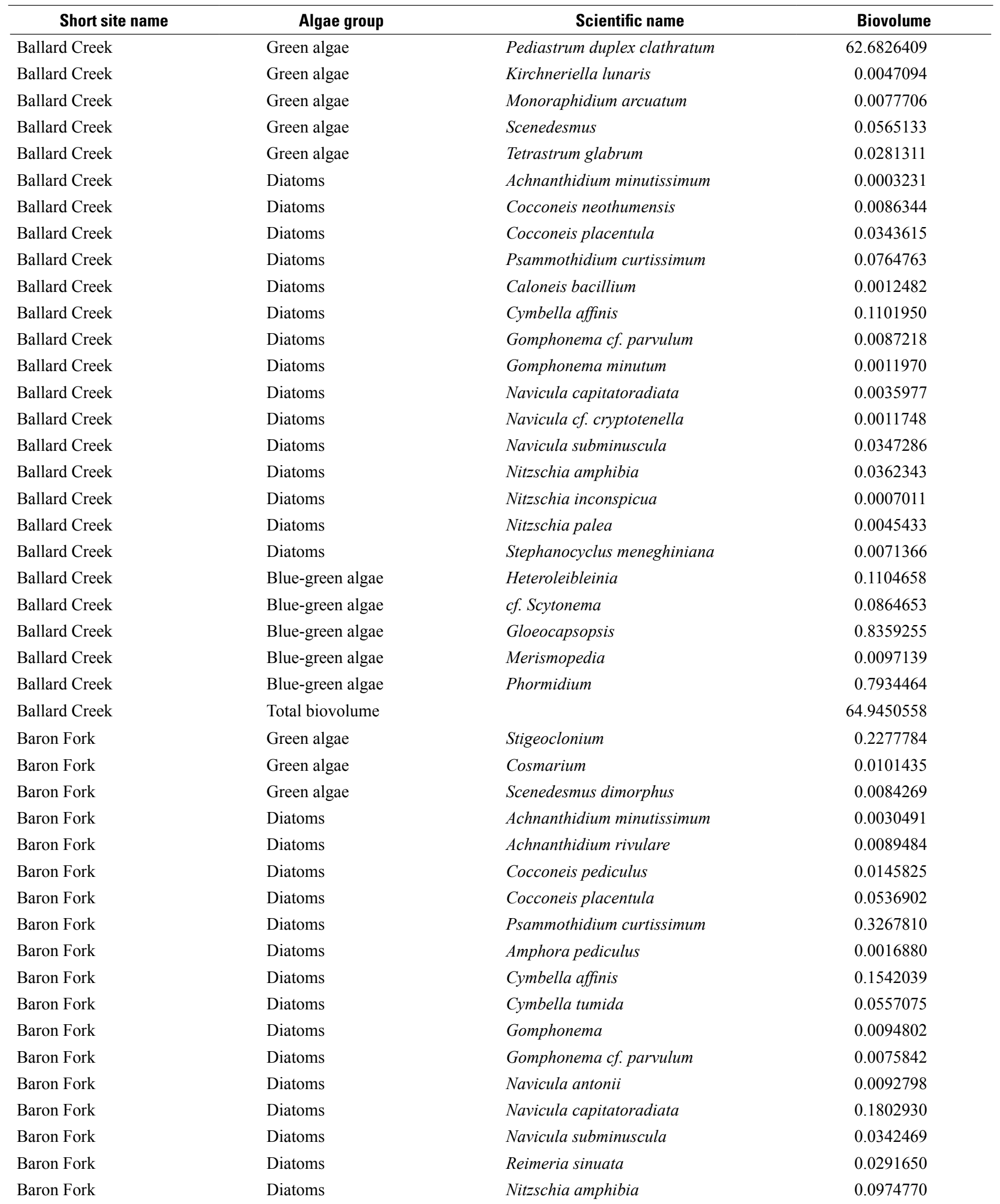


Table 10. List of algal taxa and biovolumes for sampling sites in the Illinois River Basin study area.-Continued

[Biovolume is in cubic centimeters per square meter, values are rounded to seven decimal places]

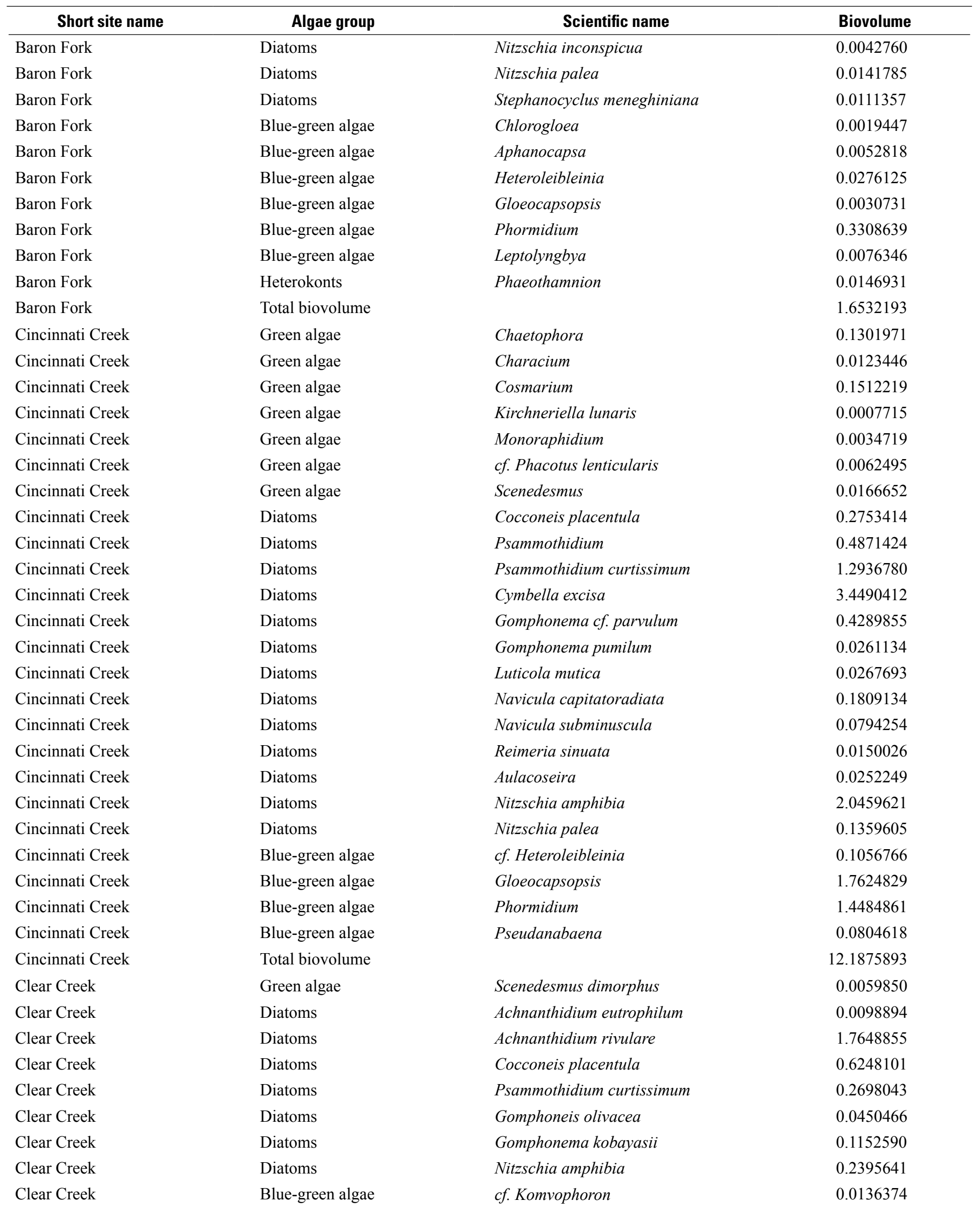




\section{Effects of Land Use, Stream Habitat, and Water Quality on Biological Communities of Wadeable Streams}

Table 10. List of algal taxa and biovolumes for sampling sites in the Illinois River Basin study area.—Continued

[Biovolume is in cubic centimeters per square meter, values are rounded to seven decimal places]

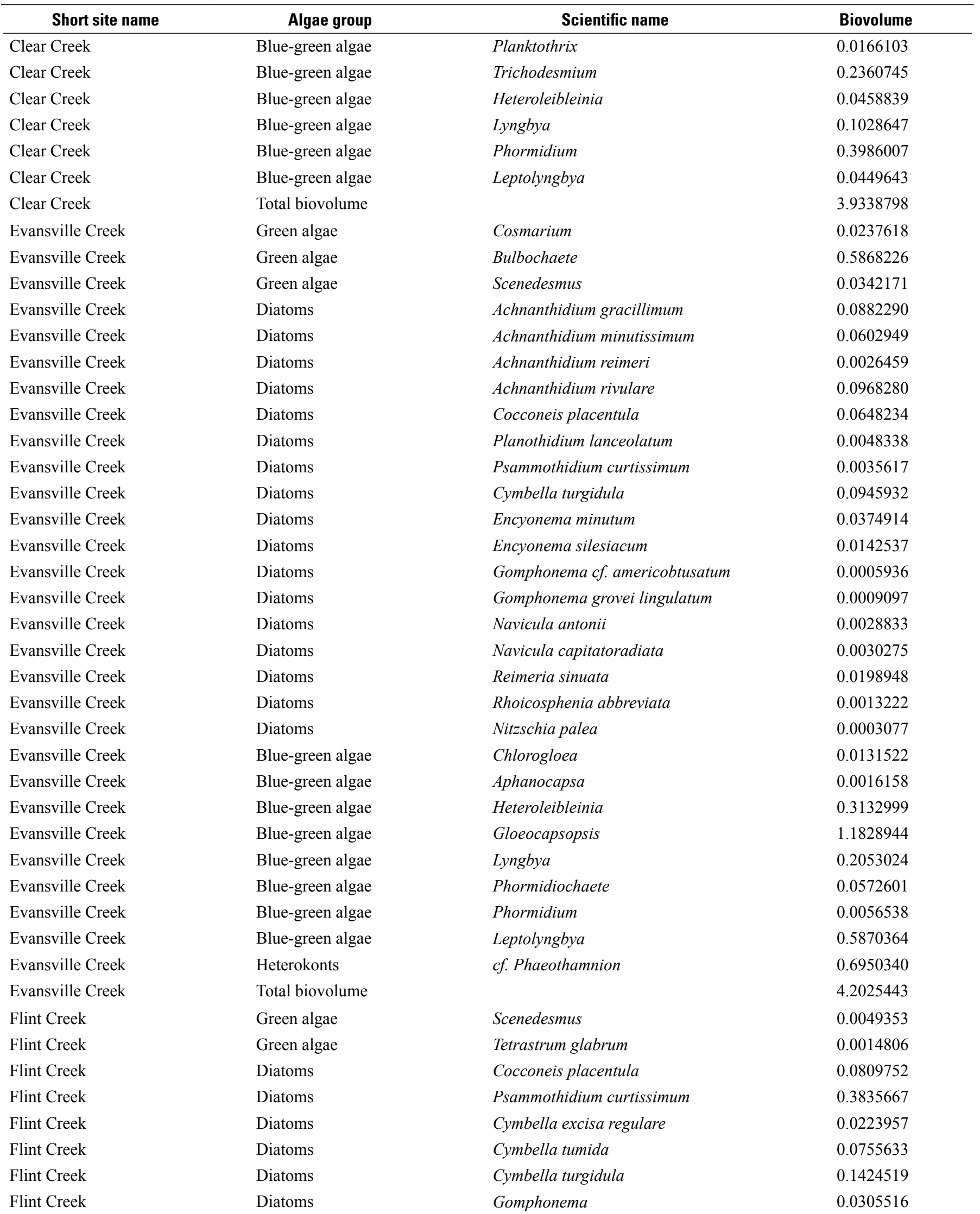


Table 10. List of algal taxa and biovolumes for sampling sites in the Illinois River Basin study area.-Continued

[Biovolume is in cubic centimeters per square meter, values are rounded to seven decimal places]

\begin{tabular}{|c|c|c|c|}
\hline Short site name & Algae group & Scientific name & Biovolume \\
\hline Flint Creek & Diatoms & Gomphonema cf. angustatum & 0.0064055 \\
\hline Flint Creek & Diatoms & Gomphonema kobayasii & 0.0048707 \\
\hline Flint Creek & Diatoms & Navicula antonii & 0.0094978 \\
\hline Flint Creek & Diatoms & Navicula capitatoradiata & 0.0701379 \\
\hline Flint Creek & Diatoms & Navicula cryptotenella & 0.0060884 \\
\hline Flint Creek & Diatoms & Navicula subminuscula & 0.0018265 \\
\hline Flint Creek & Diatoms & Reimeria sinuata & 0.0292241 \\
\hline Flint Creek & Diatoms & Nitzschia amphibia & 0.7160764 \\
\hline Flint Creek & Diatoms & Nitzschia palea & 0.0103101 \\
\hline Flint Creek & Blue-green algae & Heteroleibleinia & 0.4817273 \\
\hline Flint Creek & Blue-green algae & Gloeocapsopsis & 0.2587624 \\
\hline Flint Creek & Blue-green algae & Merismopedia & 0.0001047 \\
\hline Flint Creek & Blue-green algae & Oscillatoria & 0.0610748 \\
\hline Flint Creek & Blue-green algae & Phormidium & 0.1415824 \\
\hline Flint Creek & Total biovolume & & 2.5396094 \\
\hline Fly Creek & Green algae & Scenedesmus & 0.2048052 \\
\hline Fly Creek & Diatoms & Achnanthidium alpestre & 0.0036669 \\
\hline Fly Creek & Diatoms & Achnanthidium minutissimum & 0.0013096 \\
\hline Fly Creek & Diatoms & Achnanthidium rivulare & 0.8761290 \\
\hline Fly Creek & Diatoms & Cocconeis placentula & 0.0513367 \\
\hline Fly Creek & Diatoms & Psammothidium curtissimum & 0.0361452 \\
\hline Fly Creek & Diatoms & Gomphoneis olivacea & 0.0337301 \\
\hline Fly Creek & Diatoms & Cymbella affinis & 0.1829017 \\
\hline Fly Creek & Diatoms & Cymbella excisa & 0.0748043 \\
\hline Fly Creek & Diatoms & Encyonema minutum & 0.0135091 \\
\hline Fly Creek & Diatoms & Gomphonema & 0.0067460 \\
\hline Fly Creek & Diatoms & Gomphonema kobayasii & 0.0180721 \\
\hline Fly Creek & Diatoms & Navicula capitatoradiata & 0.1492955 \\
\hline Fly Creek & Diatoms & Reimeria sinuata & 0.0061879 \\
\hline Fly Creek & Diatoms & Rhoicosphenia abbreviata & 0.1145226 \\
\hline Fly Creek & Diatoms & Nitzschia amphibia & 0.0240113 \\
\hline Fly Creek & Diatoms & Nitzschia frustulum & 0.0078787 \\
\hline Fly Creek & Diatoms & Nitzschia inconspicua & 0.0048721 \\
\hline Fly Creek & Blue-green algae & Aphanocapsa & 0.0393167 \\
\hline Fly Creek & Blue-green algae & Heteroleibleinia & 0.1115791 \\
\hline Fly Creek & Blue-green algae & Gloeocapsopsis & 1.9352067 \\
\hline Fly Creek & Blue-green algae & Phormidium & 0.1318609 \\
\hline Fly Creek & Blue-green algae & Leptolyngbya & 0.5176241 \\
\hline Fly Creek & Total biovolume & & 4.5455115 \\
\hline Goose Creek & Green algae & cf. Characium & 0.0024950 \\
\hline Goose Creek & Green algae & Scenedesmus & 0.0403041 \\
\hline Goose Creek & Diatoms & Achnanthidium minutissimum & 0.0032888 \\
\hline Goose Creek & Diatoms & Achnanthidium rivulare & 0.1189107 \\
\hline Goose Creek & Diatoms & Cocconeis neothumensis & 0.0422851 \\
\hline Goose Creek & Diatoms & Cocconeis pediculus & 0.1452214 \\
\hline
\end{tabular}




\section{Effects of Land Use, Stream Habitat, and Water Quality on Biological Communities of Wadeable Streams}

Table 10. List of algal taxa and biovolumes for sampling sites in the Illinois River Basin study area.—Continued

[Biovolume is in cubic centimeters per square meter, values are rounded to seven decimal places]

\begin{tabular}{|c|c|c|c|}
\hline Short site name & Algae group & Scientific name & Biovolume \\
\hline Goose Creek & Diatoms & Cocconeis placentula & 0.3516067 \\
\hline Goose Creek & Diatoms & Planothidium lanceolatum & 0.0207581 \\
\hline Goose Creek & Diatoms & Caloneis bacillium & 0.0093967 \\
\hline Goose Creek & Diatoms & Cymbella affinis & 0.0313274 \\
\hline Goose Creek & Diatoms & Gomphonema truncatum & 0.0650557 \\
\hline Goose Creek & Diatoms & Navicula antonii & 0.0205018 \\
\hline Goose Creek & Diatoms & Navicula lanceolata & 0.1537639 \\
\hline Goose Creek & Diatoms & Navicula subminuscula & 0.1025092 \\
\hline Goose Creek & Diatoms & Nitzschia dissipata & 0.0462255 \\
\hline Goose Creek & Diatoms & Nitzschia inconspicua & 0.0616702 \\
\hline Goose Creek & Cryptophytes & Cryptomonas & 0.0126670 \\
\hline Goose Creek & Cryptophytes & Rhodomonas & 0.0056298 \\
\hline Goose Creek & Blue-green algae & Aphanocapsa & 0.0529231 \\
\hline Goose Creek & Blue-green algae & Heteroleibleinia & 0.0723854 \\
\hline Goose Creek & Blue-green algae & Chroococcus & 0.0159937 \\
\hline Goose Creek & Blue-green algae & Gloeocapsopsis & 12.8072238 \\
\hline Goose Creek & Blue-green algae & Phormidium & 0.1351146 \\
\hline Hamestring Creek & Diatoms & Cocconeis neothumensis & 0.0033046 \\
\hline Hamestring Creek & Diatoms & Cocconeis placentula & 0.1387921 \\
\hline Hamestring Creek & Diatoms & Planothidium lanceolatum & 0.0039655 \\
\hline Hamestring Creek & Diatoms & Psammothidium curtissimum & 0.1175107 \\
\hline Hamestring Creek & Diatoms & Cymbella affinis & 0.0589092 \\
\hline Hamestring Creek & Diatoms & Cymbella turgidula & 0.0063117 \\
\hline Hamestring Creek & Diatoms & Geissleria decussis & 0.0099137 \\
\hline Hamestring Creek & Diatoms & Gomphonema cf. pumilum & 0.0140890 \\
\hline Hamestring Creek & Diatoms & Navicula capitatoradiata & 0.0098697 \\
\hline Hamestring Creek & Diatoms & Navicula cryptotenella & 0.0076005 \\
\hline Hamestring Creek & Diatoms & Navicula menisculus & 0.0060804 \\
\hline Hamestring Creek & Diatoms & Navicula subminuscula & 0.0023793 \\
\hline Hamestring Creek & Diatoms & Reimeria sinuata & 0.0110152 \\
\hline Hamestring Creek & Diatoms & Nitzschia amphibia & 0.0017672 \\
\hline Hamestring Creek & Diatoms & Nitzschia palea & 0.0009257 \\
\hline Hamestring Creek & Diatoms & Stephanocyclus meneghiniana & 0.0039985 \\
\hline
\end{tabular}


Table 10. List of algal taxa and biovolumes for sampling sites in the Illinois River Basin study area.-Continued

[Biovolume is in cubic centimeters per square meter, values are rounded to seven decimal places]

\begin{tabular}{|c|c|c|c|}
\hline Short site name & Algae group & Scientific name & Biovolume \\
\hline Hamestring Creek & Blue-green algae & cf. Homeothrix & 0.0032955 \\
\hline Hamestring Creek & Blue-green algae & Komvophoron & 0.0206803 \\
\hline Hamestring Creek & Blue-green algae & Chlorogloea & 0.1351651 \\
\hline Hamestring Creek & Blue-green algae & Heteroleibleinia & 0.1587225 \\
\hline Hamestring Creek & Blue-green algae & Chroococcus & 0.0018537 \\
\hline Hamestring Creek & Blue-green algae & Gloeocapsopsis & 1.6627458 \\
\hline Hamestring Creek & Blue-green algae & Phormidiochaete nordstedtii & 0.3552912 \\
\hline Hamestring Creek & Blue-green algae & Phormidium & 0.0716761 \\
\hline Hamestring Creek & Blue-green algae & Leptolyngbya & 0.2391264 \\
\hline Hamestring Creek & Total biovolume & & 3.2123623 \\
\hline Illinois River & Green algae & Scenedesmus dispar & 0.0036280 \\
\hline Illinois River & Diatoms & Achnanthidium gracillimum & 0.2829572 \\
\hline Illinois River & Diatoms & Achnanthidium minutissimum & 0.5353202 \\
\hline Illinois River & Diatoms & Cocconeis placentula & 0.3766422 \\
\hline Illinois River & Diatoms & Planothidium lanceolatum & 0.0023250 \\
\hline Illinois River & Diatoms & Psammothidium curtissimum & 0.0380447 \\
\hline Illinois River & Diatoms & Rossithidium pusillum & 0.0887709 \\
\hline Illinois River & Diatoms & Cymbella affiniformis & 0.2992538 \\
\hline Illinois River & Diatoms & Cymbella cf. excisa procera & 0.4049283 \\
\hline Illinois River & Diatoms & Cymbella cf. parviformis & 0.0215333 \\
\hline Illinois River & Diatoms & Cymbella excisa & 0.2143131 \\
\hline Illinois River & Diatoms & Encyonema minutum & 0.0113058 \\
\hline Illinois River & Diatoms & Gomphonema & 0.0380447 \\
\hline Illinois River & Diatoms & Gomphonema cf. lateripunctatum & 0.0110673 \\
\hline Illinois River & Diatoms & Gomphonema grovei lingulatum & 0.0297570 \\
\hline Illinois River & Diatoms & Navicula capitatoradiata & 0.0416114 \\
\hline Illinois River & Diatoms & Reimeria sinuata & 0.0313869 \\
\hline Illinois River & Diatoms & Nitzschia amphibia & 0.0640485 \\
\hline Illinois River & Diatoms & Nitzschia sinuata tabellaria & 0.0093112 \\
\hline Illinois River & Blue-green algae & Komvophoron & 0.0009070 \\
\hline Illinois River & Blue-green algae & Heteroleibleinia & 0.0460208 \\
\hline Illinois River & Blue-green algae & Phormidiochaete nordstedtii & 0.0382641 \\
\hline Illinois River & Blue-green algae & Phormidium & 0.3599656 \\
\hline Illinois River & Blue-green algae & Leptolyngbya & 0.0233080 \\
\hline Illinois River & Blue-green algae & Limnothrix & 0.0107139 \\
\hline Illinois River & Blue-green algae & Calothrix & 0.1451200 \\
\hline Illinois River & Total biovolume & & 3.1285489 \\
\hline Little Osage Creek & Green algae & Monoraphidium arcuatum & 0.0010272 \\
\hline Little Osage Creek & Green algae & Scenedesmus & 0.0029583 \\
\hline Little Osage Creek & Green algae & Klebsormidium & 0.0851269 \\
\hline Little Osage Creek & Diatoms & Achnanthidium rivulare & 0.2042759 \\
\hline Little Osage Creek & Diatoms & Cocconeis neothumensis & 0.0107784 \\
\hline Little Osage Creek & Diatoms & Planothidium lanceolatum & 0.0038494 \\
\hline Little Osage Creek & Diatoms & Psammothidium curtissimum & 0.0217564 \\
\hline Little Osage Creek & Diatoms & Rossithidium pusillum & 0.0004220 \\
\hline
\end{tabular}




\section{Effects of Land Use, Stream Habitat, and Water Quality on Biological Communities of Wadeable Streams}

Table 10. List of algal taxa and biovolumes for sampling sites in the Illinois River Basin study area.—Continued

[Biovolume is in cubic centimeters per square meter, values are rounded to seven decimal places]

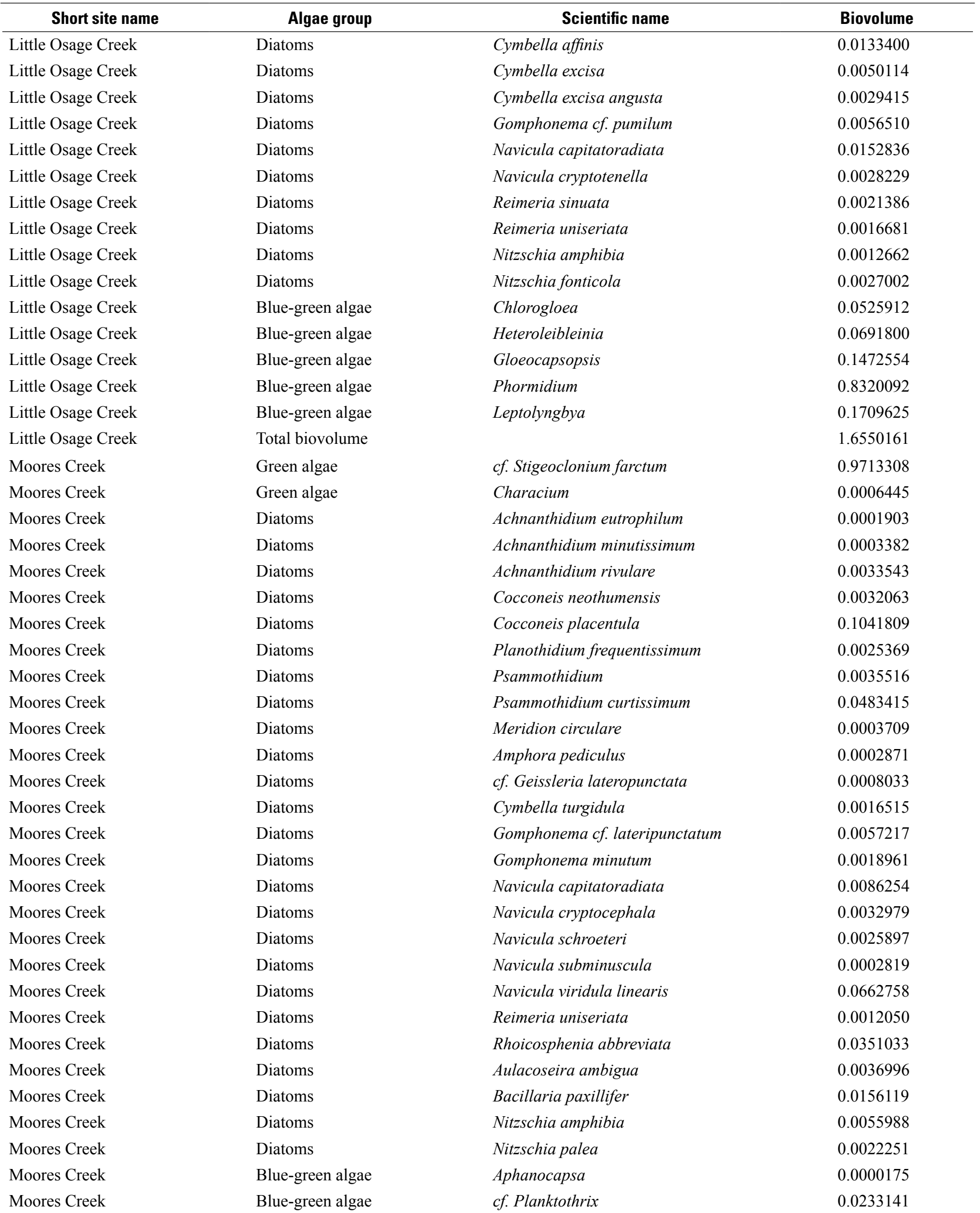


Table 10. List of algal taxa and biovolumes for sampling sites in the Illinois River Basin study area.-Continued

[Biovolume is in cubic centimeters per square meter, values are rounded to seven decimal places]

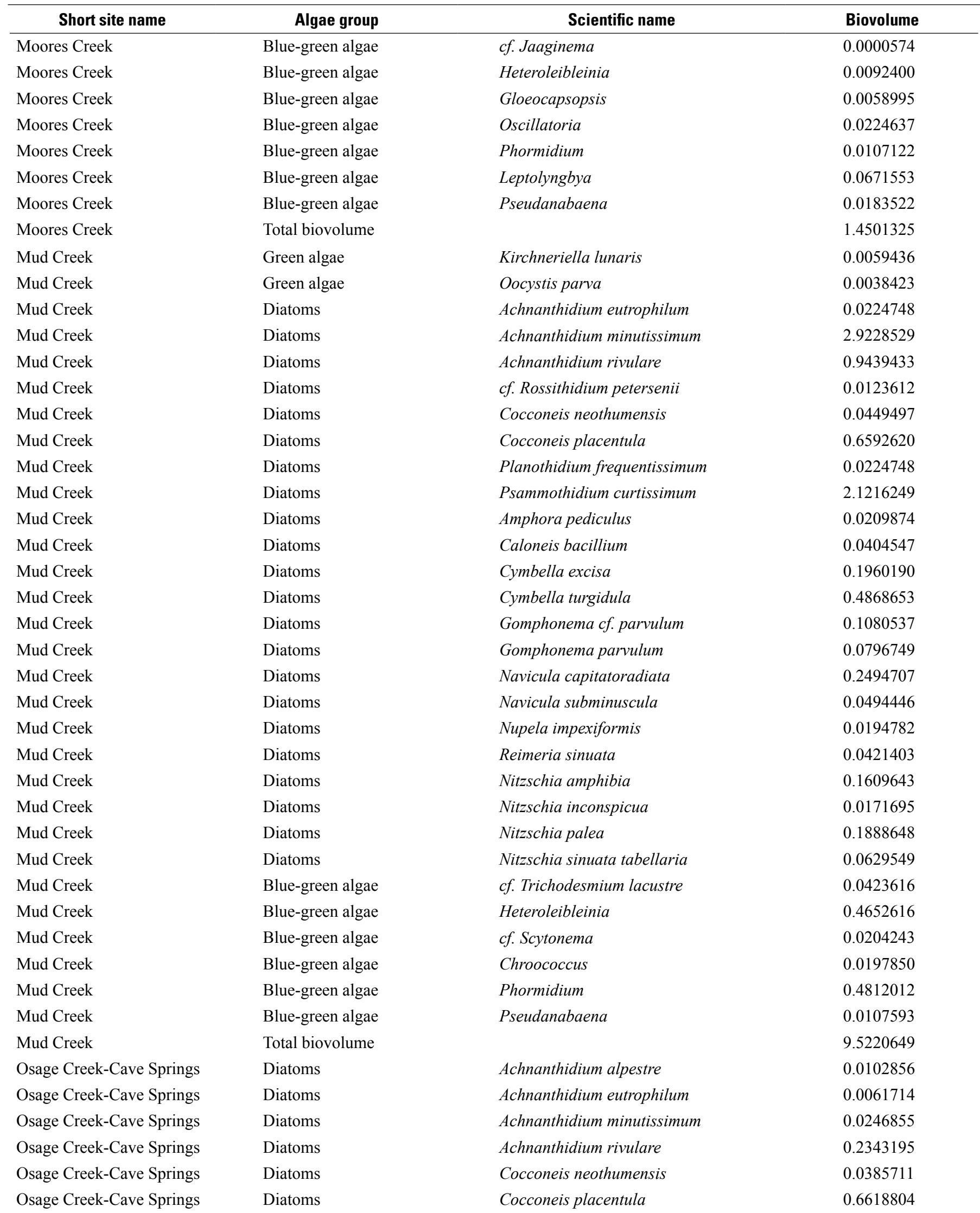




\section{Effects of Land Use, Stream Habitat, and Water Quality on Biological Communities of Wadeable Streams}

Table 10. List of algal taxa and biovolumes for sampling sites in the Illinois River Basin study area.-Continued

[Biovolume is in cubic centimeters per square meter, values are rounded to seven decimal places]

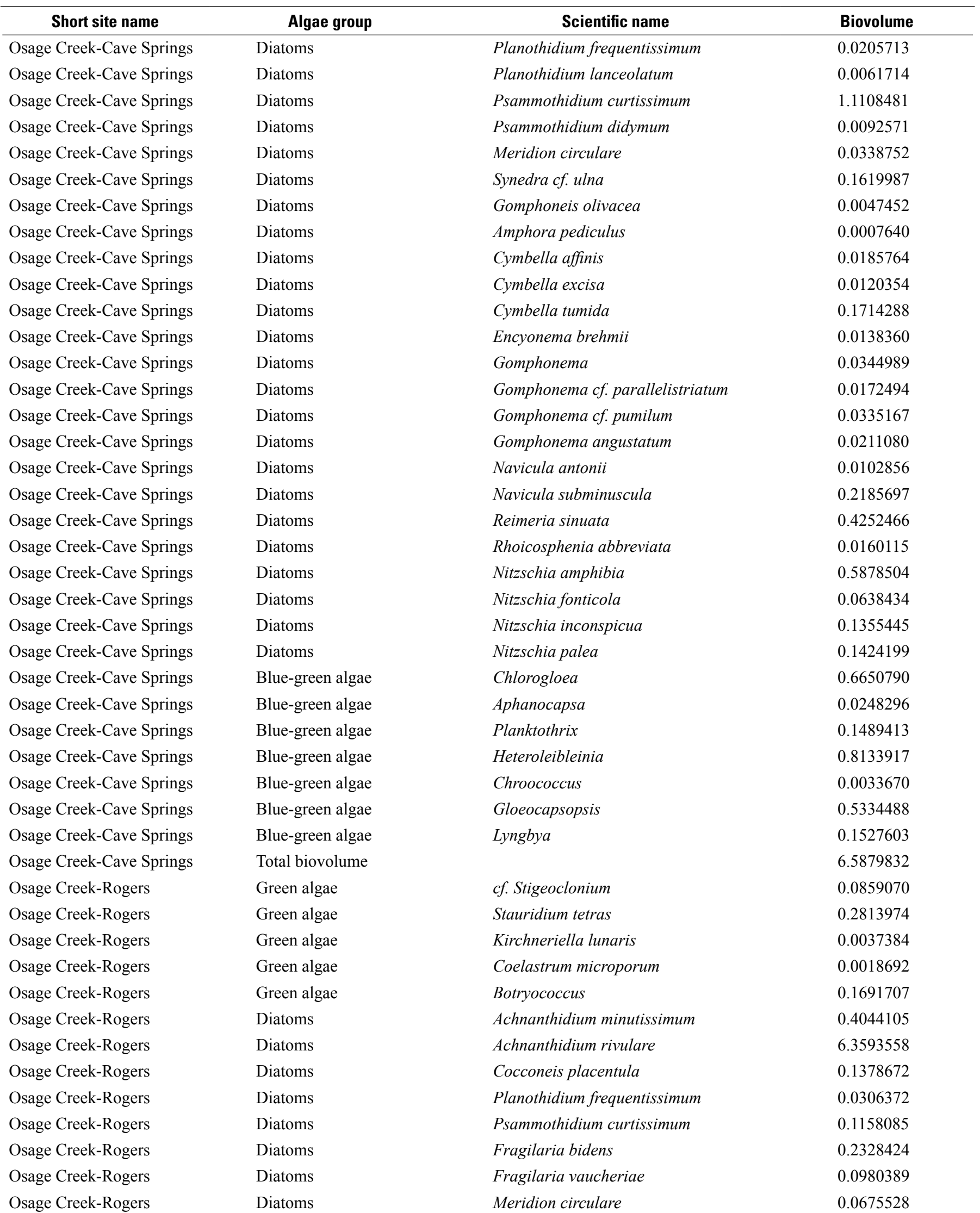


Table 10. List of algal taxa and biovolumes for sampling sites in the Illinois River Basin study area.-Continued

[Biovolume is in cubic centimeters per square meter, values are rounded to seven decimal places]

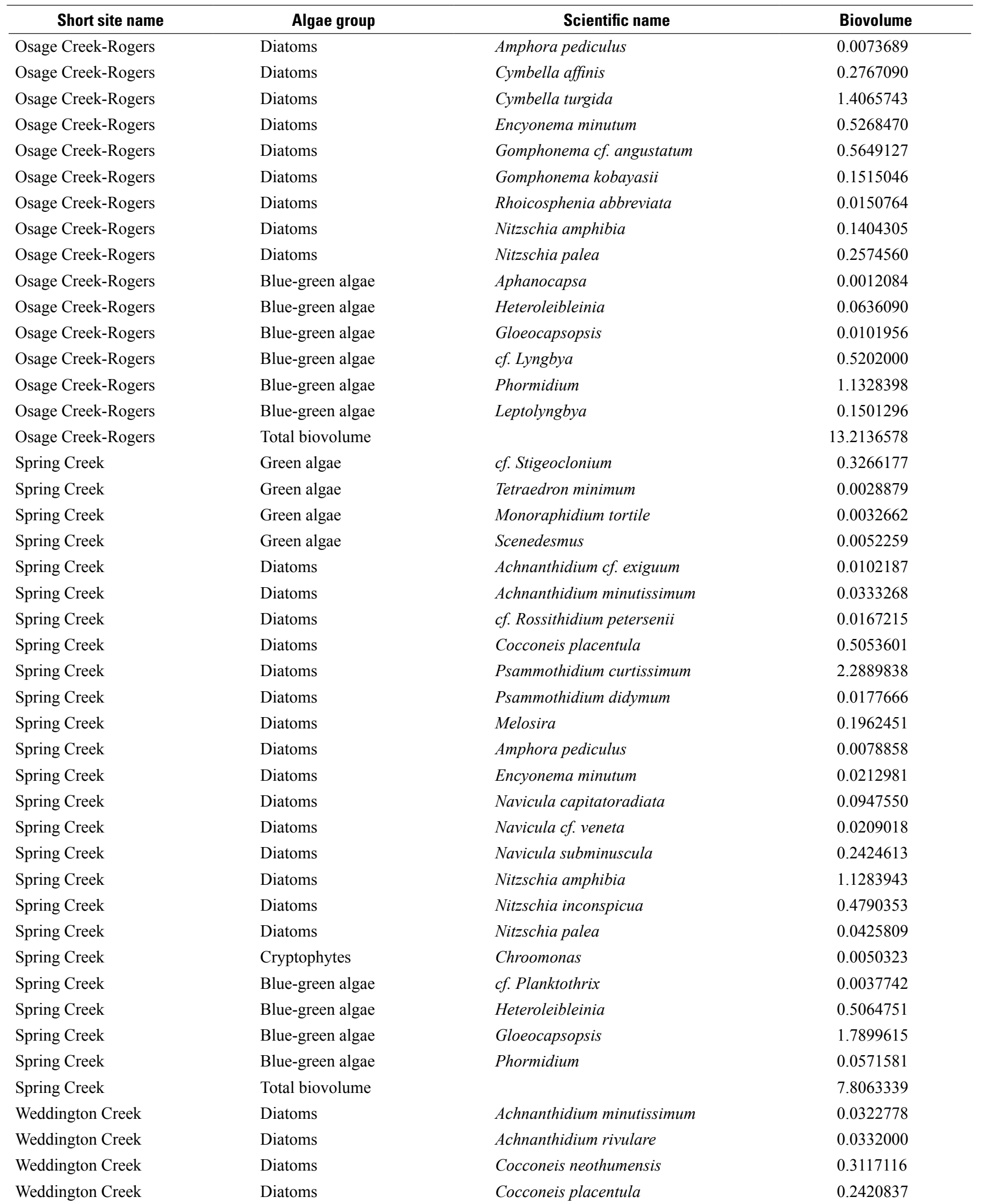


Table 10. List of algal taxa and biovolumes for sampling sites in the Illinois River Basin study area.-Continued

[Biovolume is in cubic centimeters per square meter, values are rounded to seven decimal places]




Table 11. Periphyton metric values at sampling sites in the Illinois River Basin study area.

[Biovolume is in cubic centimeters per square meter, values shown are rounded to one decimal place, percent biovolumes calculated from raw values]

\begin{tabular}{|c|c|c|c|c|c|c|c|c|c|c|c|c|}
\hline $\begin{array}{c}\text { Short } \\
\text { site name }\end{array}$ & $\begin{array}{c}\text { Total } \\
\text { biovolume }\end{array}$ & $\begin{array}{c}\text { Blue- } \\
\text { green } \\
\text { algae } \\
\text { biovolume }\end{array}$ & $\begin{array}{c}\text { Blue- } \\
\text { green } \\
\text { algae } \\
\text { percent } \\
\text { biovolume }\end{array}$ & $\begin{array}{c}\text { Green } \\
\text { algae } \\
\text { biovolume }\end{array}$ & $\begin{array}{c}\text { Green } \\
\text { algae } \\
\text { percent } \\
\text { biovolume }\end{array}$ & $\begin{array}{c}\text { Diatom } \\
\text { biovolume }\end{array}$ & $\begin{array}{c}\text { Diatom } \\
\text { percent } \\
\text { biovolume }\end{array}$ & $\begin{array}{c}\text { Gloeo- } \\
\text { capsopsis } \\
\text { biovolume }\end{array}$ & $\begin{array}{c}\text { Hetero- } \\
\text { leibleinia } \\
\text { biovolume }\end{array}$ & $\begin{array}{c}\text { Phor- } \\
\text { midium } \\
\text { biovolume }\end{array}$ & $\begin{array}{c}\text { Nitzschia } \\
\text { amphibia } \\
\text { biovolume }\end{array}$ & $\begin{array}{l}\text { Cocconeis } \\
\text { placentula } \\
\text { biovolume }\end{array}$ \\
\hline Ballard Creek & 64.9 & 1.8 & 2.8 & 62.78 & 96.7 & 0.3 & 0.5 & 0.84 & 0.11 & 0.79 & 0.04 & 0.03 \\
\hline Baron Fork & 1.7 & 0.4 & 22.8 & 0.25 & 14.9 & 1.0 & 61.4 & 0.00 & 0.03 & 0.33 & 0.10 & 0.05 \\
\hline Cincinnati Creek & 12.2 & 3.4 & 27.9 & 0.32 & 2.6 & 8.5 & 69.5 & 1.76 & 0.00 & 1.45 & 2.05 & 0.28 \\
\hline Clear Creek & 3.9 & 0.9 & 21.8 & 0.01 & 0.2 & 3.1 & 78.0 & 0.00 & 0.05 & 0.40 & 0.24 & 0.62 \\
\hline Evansville Creek & 4.2 & 2.4 & 56.3 & 0.64 & 15.3 & 0.5 & 11.8 & 1.18 & 0.31 & 0.01 & 0.00 & 0.06 \\
\hline Flint Creek & 2.5 & 0.9 & 37.1 & 0.01 & 0.3 & 1.6 & 62.6 & 0.26 & 0.48 & 0.14 & 0.72 & 0.08 \\
\hline Fly Creek & 4.5 & 2.7 & 60.2 & 0.20 & 4.5 & 1.6 & 35.3 & 1.94 & 0.11 & 0.13 & 0.02 & 0.05 \\
\hline Goose Creek & 14.6 & 13.1 & 89.8 & 0.04 & 0.3 & 1.4 & 9.8 & 12.81 & 0.07 & 0.14 & 0.01 & 0.35 \\
\hline $\begin{array}{l}\text { Hamestring } \\
\text { Creek }\end{array}$ & 3.2 & 2.6 & 82.4 & 0.02 & 0.5 & 0.5 & 17.0 & 1.66 & 0.16 & 0.07 & 0.00 & 0.14 \\
\hline Illinois River & 3.1 & 0.6 & 20.0 & 0.00 & 0.1 & 2.5 & 79.9 & 0.00 & 0.05 & 0.36 & 0.06 & 0.38 \\
\hline $\begin{array}{l}\text { Little Osage } \\
\text { Creek }\end{array}$ & 1.7 & 1.3 & 76.9 & 0.09 & 5.4 & 0.3 & 17.8 & 0.15 & 0.07 & 0.83 & 0.00 & 0.00 \\
\hline Moores Creek & 1.5 & 0.2 & 10.8 & 0.97 & 67.0 & 0.3 & 22.1 & 0.01 & 0.01 & 0.01 & 0.01 & 0.10 \\
\hline Mud Creek & 9.5 & 1.0 & 10.9 & 0.01 & 0.1 & 8.5 & 89.0 & 0.00 & 0.47 & 0.48 & 0.16 & 0.66 \\
\hline $\begin{array}{l}\text { Osage Creek- } \\
\text { Rogers }\end{array}$ & 13.2 & 1.9 & 14.2 & 0.54 & 4.1 & 10.8 & 81.7 & 0.01 & 0.06 & 1.13 & 0.14 & 0.14 \\
\hline $\begin{array}{l}\text { Osage Creek- } \\
\text { Cave Springs }\end{array}$ & 6.6 & 2.3 & 35.5 & 0.00 & 0.0 & 4.2 & 64.5 & 0.53 & 0.81 & 0.00 & 0.59 & 0.66 \\
\hline Spring Creek & 7.8 & 2.4 & 30.2 & 0.34 & 4.3 & 5.1 & 65.4 & 1.79 & 0.51 & 0.06 & 1.13 & 0.51 \\
\hline $\begin{array}{l}\text { Weddington } \\
\text { Creek }\end{array}$ & 10.0 & 5.1 & 51.0 & 0.00 & 0.0 & 4.9 & 49.0 & 0.10 & 0.15 & 2.69 & 1.08 & 0.24 \\
\hline Wildcat Creek & 4.1 & 3.0 & 72.0 & 0.00 & 0.0 & 1.2 & 28.0 & 0.21 & 4.38 & 0.18 & 0.38 & 0.02 \\
\hline
\end{tabular}


Table 12. Correlations between periphyton metrics and selected environmental factors in the Illinois River Basin study area.

[Red font denotes absolute value of rho is greater than or equal to 0.50 ; number of sites equals 18 ]

\begin{tabular}{|c|c|c|c|c|c|c|c|c|c|c|c|c|c|}
\hline & $\begin{array}{l}\text { Nitrite } \\
\text { plus } \\
\text { nitrate }\end{array}$ & $\begin{array}{l}\text { Total } \\
\text { phos- } \\
\text { phorus }\end{array}$ & $\begin{array}{l}\text { Temper- } \\
\text { ature }\end{array}$ & $\begin{array}{c}\text { Specific } \\
\text { conduc- } \\
\text { tance }\end{array}$ & $\begin{array}{l}\text { Dissolved } \\
\text { oxygen }\end{array}$ & $\mathrm{pH}$ & $\begin{array}{l}\text { Stream- } \\
\text { flow }\end{array}$ & $\begin{array}{c}\text { Bankfull } \\
\text { width }\end{array}$ & $\begin{array}{c}\text { Drainage } \\
\text { area }\end{array}$ & $\begin{array}{l}\text { Bankfull } \\
\text { width/ } \\
\text { drainage } \\
\text { area } \\
\end{array}$ & Depth & Velocity & $\begin{array}{c}\text { Bed } \\
\text { substrate }\end{array}$ \\
\hline Total periphyton biovolume & 0.07 & 0.07 & 0.38 & 0.55 & 0.10 & -0.07 & 0.19 & 0.24 & -0.10 & 0.12 & -0.02 & 0.04 & -0.19 \\
\hline Blue-green algae biovolume & 0.41 & 0.02 & 0.19 & 0.46 & 0.22 & -0.08 & 0.22 & 0.25 & -0.26 & 0.26 & 0.01 & 0.19 & 0.06 \\
\hline Blue-green algae percent biovolume & 0.59 & -0.18 & -0.26 & 0.22 & 0.38 & 0.06 & 0.31 & -0.02 & -0.26 & 0.19 & 0.09 & 0.40 & 0.30 \\
\hline Green algae biovolume & -0.18 & 0.10 & 0.20 & -0.02 & 0.04 & -0.23 & -0.18 & -0.22 & -0.03 & -0.26 & -0.30 & -0.13 & -0.20 \\
\hline Green algae percent biovolume & -0.13 & 0.08 & 0.03 & -0.18 & 0.16 & -0.15 & -0.20 & -0.26 & 0.03 & -0.31 & -0.37 & -0.16 & -0.07 \\
\hline Diatom biovolume & -0.03 & -0.03 & 0.01 & 0.41 & -0.36 & -0.14 & 0.10 & 0.03 & -0.08 & 0.09 & 0.26 & 0.11 & 0.00 \\
\hline Diatom percent biovolume & -0.22 & -0.13 & -0.14 & 0.07 & -0.50 & -0.13 & -0.07 & -0.04 & 0.06 & 0.01 & 0.24 & 0.04 & 0.05 \\
\hline Gloeocapsopsis biovolume & 0.33 & 0.22 & 0.13 & 0.46 & 0.40 & -0.11 & 0.27 & 0.03 & -0.22 & -0.01 & -0.13 & 0.21 & 0.10 \\
\hline Heteroleibleinia biovolume & 0.16 & 0.09 & 0.12 & 0.42 & 0.06 & 0.36 & 0.42 & -0.05 & -0.06 & -0.03 & 0.11 & 0.17 & -0.17 \\
\hline Phormidium biovolume & 0.17 & -0.18 & 0.08 & -0.13 & 0.10 & 0.10 & 0.01 & 0.21 & 0.02 & 0.12 & -0.10 & 0.02 & -0.26 \\
\hline Nitzschia amphibia biovolume & 0.09 & 0.49 & 0.19 & 0.18 & -0.15 & 0.32 & 0.35 & 0.03 & -0.05 & -0.01 & 0.16 & 0.22 & -0.05 \\
\hline \multirow[t]{2}{*}{ Cocconeis placentula biovolume } & -0.38 & 0.06 & 0.11 & 0.34 & -0.52 & -0.12 & 0.03 & 0.06 & -0.12 & 0.22 & 0.43 & 0.09 & 0.25 \\
\hline & $\begin{array}{l}\text { Embed- } \\
\text { dedness }\end{array}$ & $\begin{array}{c}\text { Substrate } \\
\text { turbidity }\end{array}$ & $\begin{array}{c}\text { Open } \\
\text { canopy } \\
\text { angle }\end{array}$ & $\begin{array}{c}\text { Combined } \\
\text { canopy } \\
\text { closure }\end{array}$ & $\begin{array}{l}\text { Bank } \\
\text { height }\end{array}$ & $\begin{array}{l}\text { Bank } \\
\text { angle }\end{array}$ & $\begin{array}{c}\text { Percent } \\
\text { forest }\end{array}$ & $\begin{array}{c}\text { Percent } \\
\text { urban }\end{array}$ & $\begin{array}{c}\text { Percent } \\
\text { agriculture }\end{array}$ & $\begin{array}{c}\text { Poultry } \\
\text { house } \\
\text { density }\end{array}$ & $\begin{array}{l}\text { Total } \\
\text { unpaved } \\
\text { road } \\
\text { density }\end{array}$ & $\begin{array}{c}\text { Total } \\
\text { paved } \\
\text { road } \\
\text { density }\end{array}$ & $\begin{array}{c}\text { Total } \\
\text { road } \\
\text { density }\end{array}$ \\
\hline Total periphyton biovolume & -0.16 & -0.47 & 0.45 & -0.46 & -0.12 & -0.15 & -0.19 & 0.19 & -0.17 & -0.29 & -0.27 & 0.23 & 0.16 \\
\hline Blue-green algae biovolume & -0.19 & -0.49 & 0.46 & -0.55 & -0.12 & 0.32 & -0.01 & -0.10 & 0.13 & -0.22 & 0.09 & -0.10 & -0.08 \\
\hline Blue-green algae percent biovolume & -0.27 & -0.29 & 0.16 & -0.18 & -0.03 & 0.40 & 0.01 & -0.13 & 0.24 & -0.16 & 0.24 & -0.15 & -0.06 \\
\hline Green algae biovolume & 0.29 & 0.37 & -0.39 & 0.35 & 0.23 & -0.03 & 0.09 & 0.00 & -0.12 & 0.27 & 0.13 & -0.05 & -0.04 \\
\hline Green algae percent biovolume & 0.14 & 0.37 & -0.58 & 0.48 & 0.19 & -0.00 & 0.20 & -0.15 & 0.05 & 0.43 & 0.25 & -0.18 & -0.18 \\
\hline Diatom biovolume & 0.18 & -0.16 & 0.56 & -0.42 & -0.15 & 0.02 & -0.27 & 0.32 & -0.49 & -0.47 & -0.55 & 0.28 & 0.30 \\
\hline Diatom percent biovolume & 0.27 & 0.16 & 0.35 & -0.17 & -0.17 & -0.03 & -0.23 & 0.29 & -0.49 & -0.32 & -0.53 & 0.23 & 0.25 \\
\hline Gloeocapsopsis biovolume & -0.22 & -0.41 & 0.09 & -0.19 & 0.22 & 0.44 & 0.08 & -0.07 & 0.05 & 0.01 & 0.20 & -0.12 & -0.04 \\
\hline Heteroleibleinia biovolume & -0.17 & -0.31 & 0.24 & -0.16 & 0.07 & 0.12 & -0.18 & 0.14 & -0.18 & -0.44 & -0.17 & 0.23 & 0.27 \\
\hline Phormidium biovolume & 0.10 & 0.01 & 0.26 & -0.06 & -0.57 & -0.29 & -0.13 & 0.01 & 0.31 & 0.25 & -0.01 & -0.02 & -0.09 \\
\hline Nitzschia amphibia biovolume & 0.16 & -0.39 & 0.52 & -0.32 & -0.33 & -0.03 & -0.16 & 0.16 & -0.01 & -0.01 & -0.20 & 0.09 & 0.10 \\
\hline Cocconeis placentula biovolume & -0.03 & -0.29 & 0.26 & -0.29 & 0.24 & 0.01 & -0.28 & 0.42 & -0.59 & -0.56 & -0.59 & 0.43 & 0.41 \\
\hline
\end{tabular}


Table 13. List of macroinvertebrate taxa and relative abundances for sampling sites in the Illinois River Basin study area.

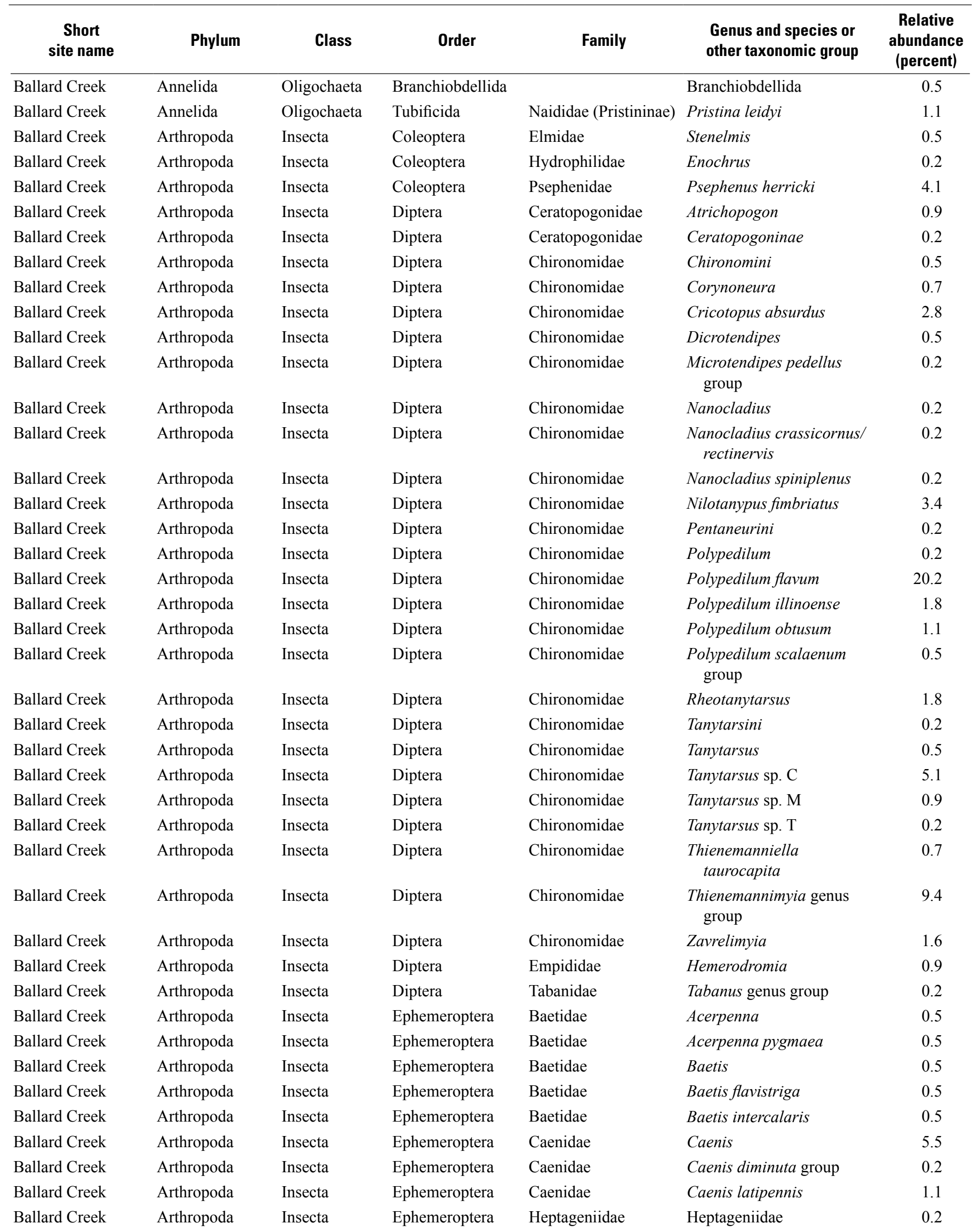


Table 13. List of macroinvertebrate taxa and relative abundances for sampling sites in the Illinois River Basin study area.—Continued

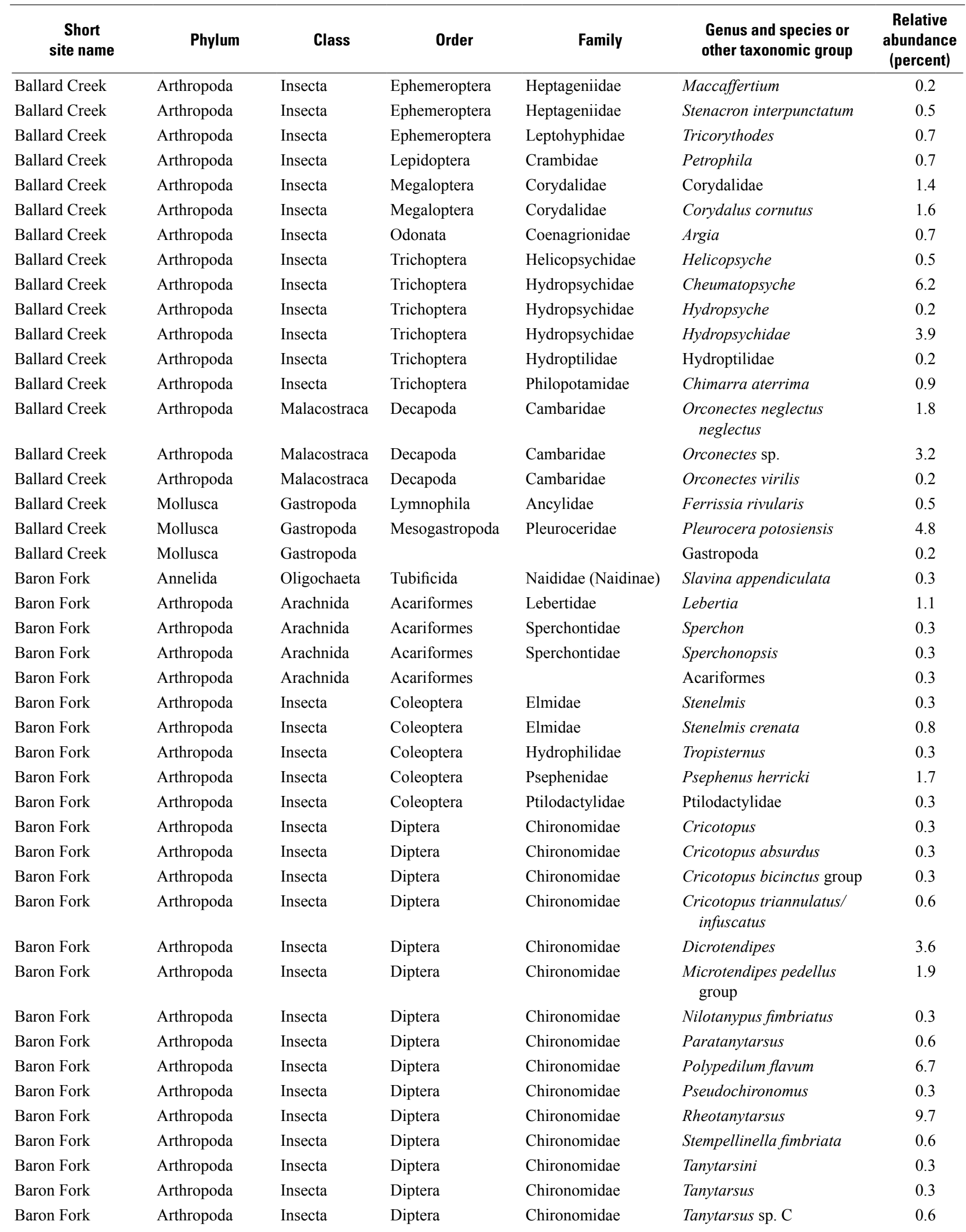


Table 13

Table 13. List of macroinvertebrate taxa and relative abundances for sampling sites in the Illinois River Basin study area.—Continued

\begin{tabular}{|c|c|c|c|c|c|c|}
\hline $\begin{array}{l}\text { Short } \\
\text { site name }\end{array}$ & Phylum & Class & Order & Family & $\begin{array}{l}\text { Genus and species or } \\
\text { other taxonomic group }\end{array}$ & $\begin{array}{c}\text { Relative } \\
\text { abundance } \\
\text { (percent) }\end{array}$ \\
\hline Baron Fork & Arthropoda & Insecta & Diptera & Chironomidae & Tanytarsus sp. M & 0.6 \\
\hline Baron Fork & Arthropoda & Insecta & Diptera & Chironomidae & Thienemanniella sp. B & 0.6 \\
\hline Baron Fork & Arthropoda & Insecta & Diptera & Chironomidae & $\begin{array}{l}\text { Thienemannimyia genus } \\
\text { group }\end{array}$ & 2.5 \\
\hline Baron Fork & Arthropoda & Insecta & Diptera & Empididae & Hemerodromia & 0.3 \\
\hline Baron Fork & Arthropoda & Insecta & Diptera & Tabanidae & Tabanidae & 0.3 \\
\hline Baron Fork & Arthropoda & Insecta & Diptera & Tabanidae & Tabanus genus group & 0.3 \\
\hline Baron Fork & Arthropoda & Insecta & Diptera & Tipulidae & Tipulidae & 0.3 \\
\hline Baron Fork & Arthropoda & Insecta & Ephemeroptera & Baetidae & Acentrella parvula & 0.3 \\
\hline Baron Fork & Arthropoda & Insecta & Ephemeroptera & Caenidae & Caenis punctata & 0.3 \\
\hline Baron Fork & Arthropoda & Insecta & Ephemeroptera & Heptageniidae & Heptageniidae & 0.3 \\
\hline Baron Fork & Arthropoda & Insecta & Ephemeroptera & Heptageniidae & Leucrocuta & 1.1 \\
\hline Baron Fork & Arthropoda & Insecta & Ephemeroptera & Heptageniidae & Leucrocuta/Nixe & 0.6 \\
\hline Baron Fork & Arthropoda & Insecta & Ephemeroptera & Heptageniidae & $\begin{array}{l}\text { Maccaffertium terminatum/ } \\
\text { pulchellum }\end{array}$ & 14.2 \\
\hline Baron Fork & Arthropoda & Insecta & Ephemeroptera & Heptageniidae & Stenacron & 3.6 \\
\hline Baron Fork & Arthropoda & Insecta & Ephemeroptera & Heptageniidae & Stenacron interpunctatum & 3.1 \\
\hline Baron Fork & Arthropoda & Insecta & Ephemeroptera & Heptageniidae & Stenonema femoratum & 0.3 \\
\hline Baron Fork & Arthropoda & Insecta & Odonata & Gomphidae & Hagenius brevistylus & 0.6 \\
\hline Baron Fork & Arthropoda & Insecta & Plecoptera & Perlidae & Neoperla harpi & 0.6 \\
\hline Baron Fork & Arthropoda & Insecta & Trichoptera & Helicopsychidae & Helicopsyche limnella & 4.4 \\
\hline Baron Fork & Arthropoda & Insecta & Trichoptera & Hydropsychidae & Cheumatopsyche & 8.9 \\
\hline Baron Fork & Arthropoda & Insecta & Trichoptera & Hydropsychidae & Hydropsychidae & 0.3 \\
\hline Baron Fork & Arthropoda & Insecta & Trichoptera & Hydroptilidae & Hydroptila & 2.2 \\
\hline Baron Fork & Arthropoda & Insecta & Trichoptera & Hydroptilidae & Hydroptila & 0.6 \\
\hline Baron Fork & Arthropoda & Malacostraca & Decapoda & Cambaridae & Orconectes sp. & 0.6 \\
\hline Baron Fork & Arthropoda & Malacostraca & Decapoda & Cambaridae & Orconectes sp. & 0.6 \\
\hline Baron Fork & Mollusca & Gastropoda & Basommatophora & Ancylidae & Ferrissia & 1.4 \\
\hline Baron Fork & Mollusca & Gastropoda & Basommatophora & Ancylidae & Ferrissia fragilis & 0.3 \\
\hline Baron Fork & Mollusca & Gastropoda & Basommatophora & Lymnaeidae & Lymnaeidae & 0.6 \\
\hline Baron Fork & Mollusca & Gastropoda & Basommatophora & Physidae & Physa & 0.6 \\
\hline Baron Fork & Platyhelminthes & Turbellaria & Tricladida & Dugesiidae & Cura & 0.3 \\
\hline Cincinnati Creek & Annelida & Oligochaeta & Lumbriculida & Sparganophilidae & Sparganophilus & 0.3 \\
\hline Cincinnati Creek & Annelida & Oligochaeta & Tubificida & Naididae (Tubificinae) & $\begin{array}{l}\text { Naididae (Tubificinae) } \\
\text { Unid. }\end{array}$ & 0.3 \\
\hline Cincinnati Creek & Arthropoda & Arachnida & Acariformes & Hygrobatidae & Atracides & 0.3 \\
\hline
\end{tabular}


Table 13. List of macroinvertebrate taxa and relative abundances for sampling sites in the Illinois River Basin study area.—Continued

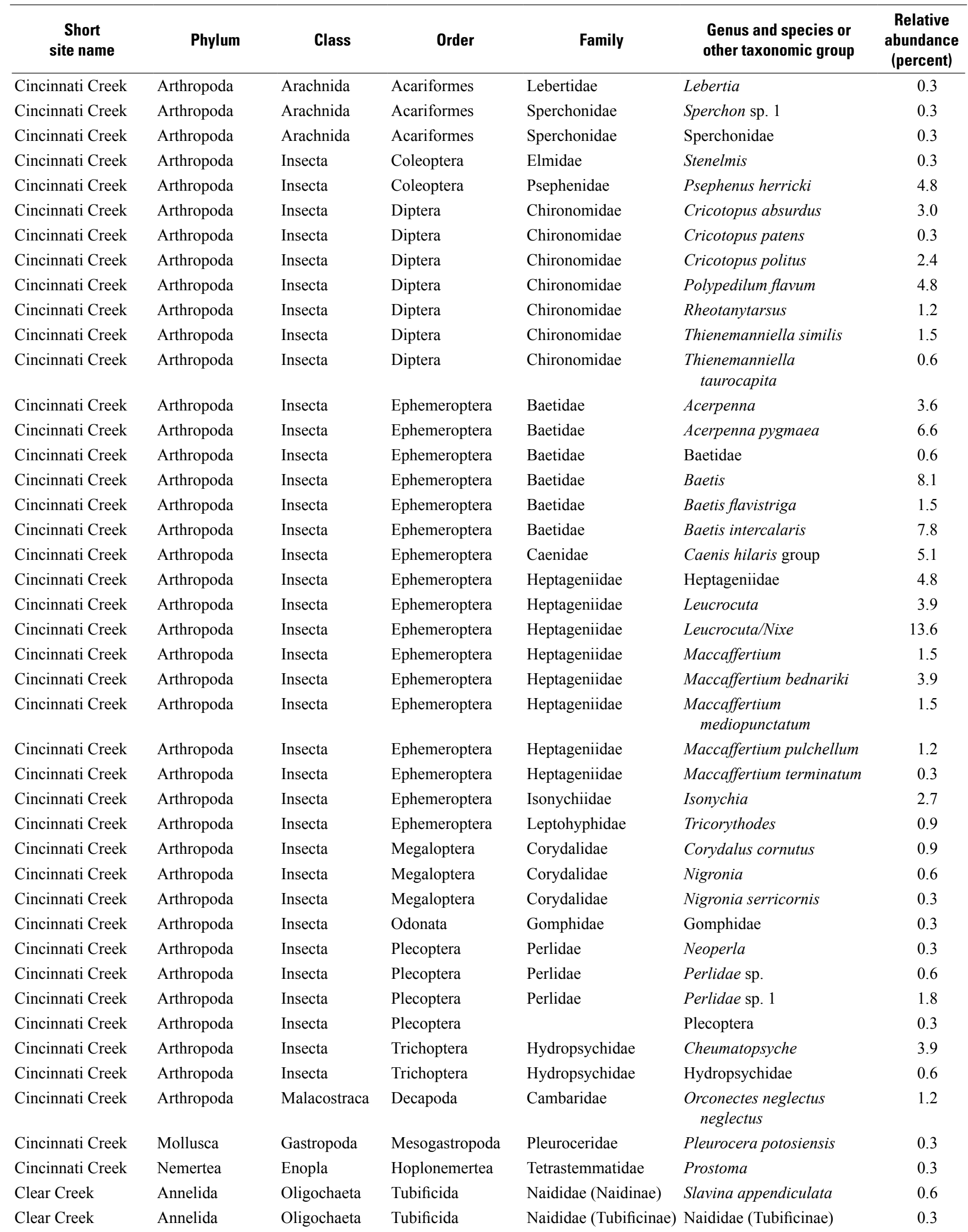


Table 13

Table 13. List of macroinvertebrate taxa and relative abundances for sampling sites in the Illinois River Basin study area.—Continued

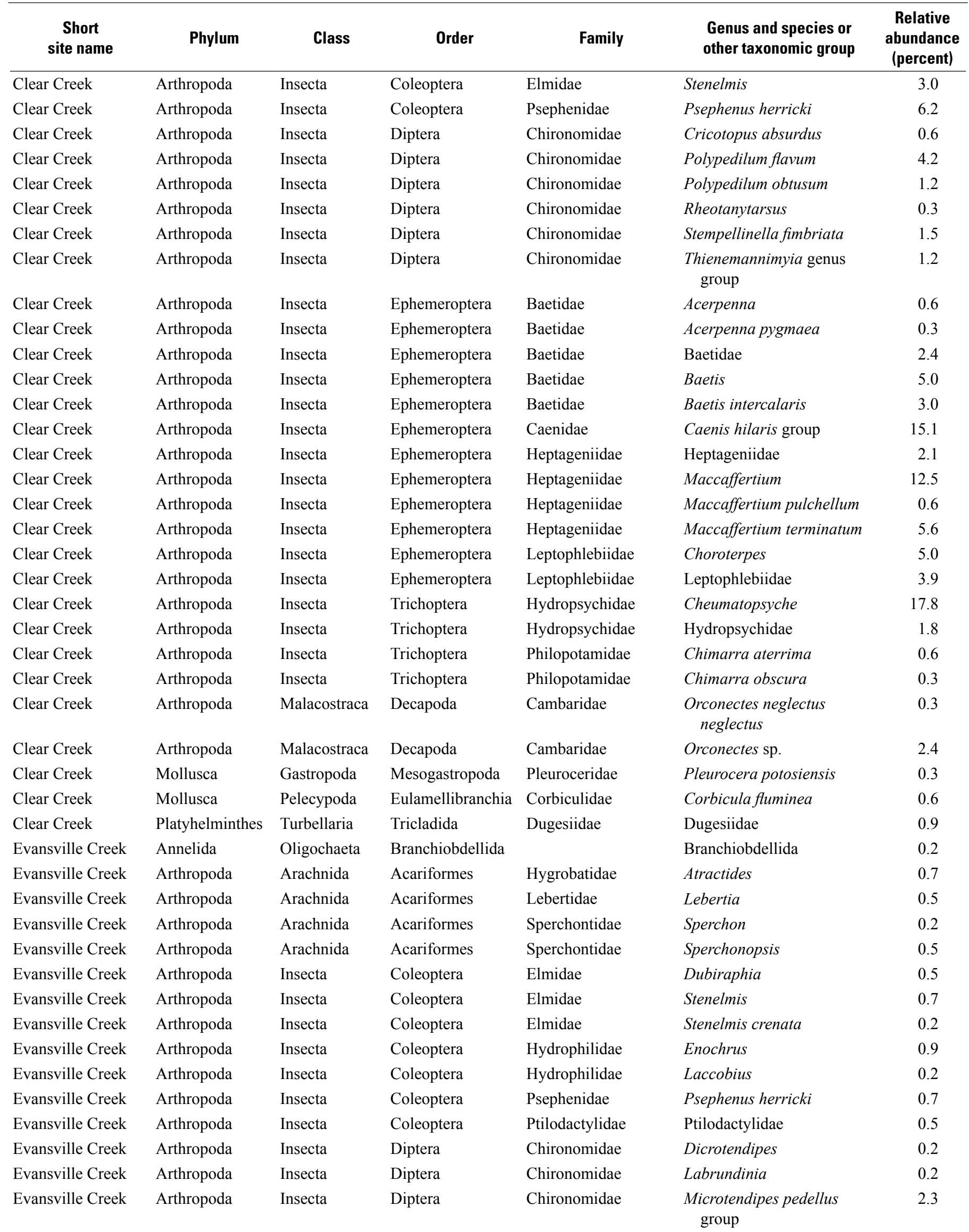


Table 13. List of macroinvertebrate taxa and relative abundances for sampling sites in the Illinois River Basin study area.—Continued

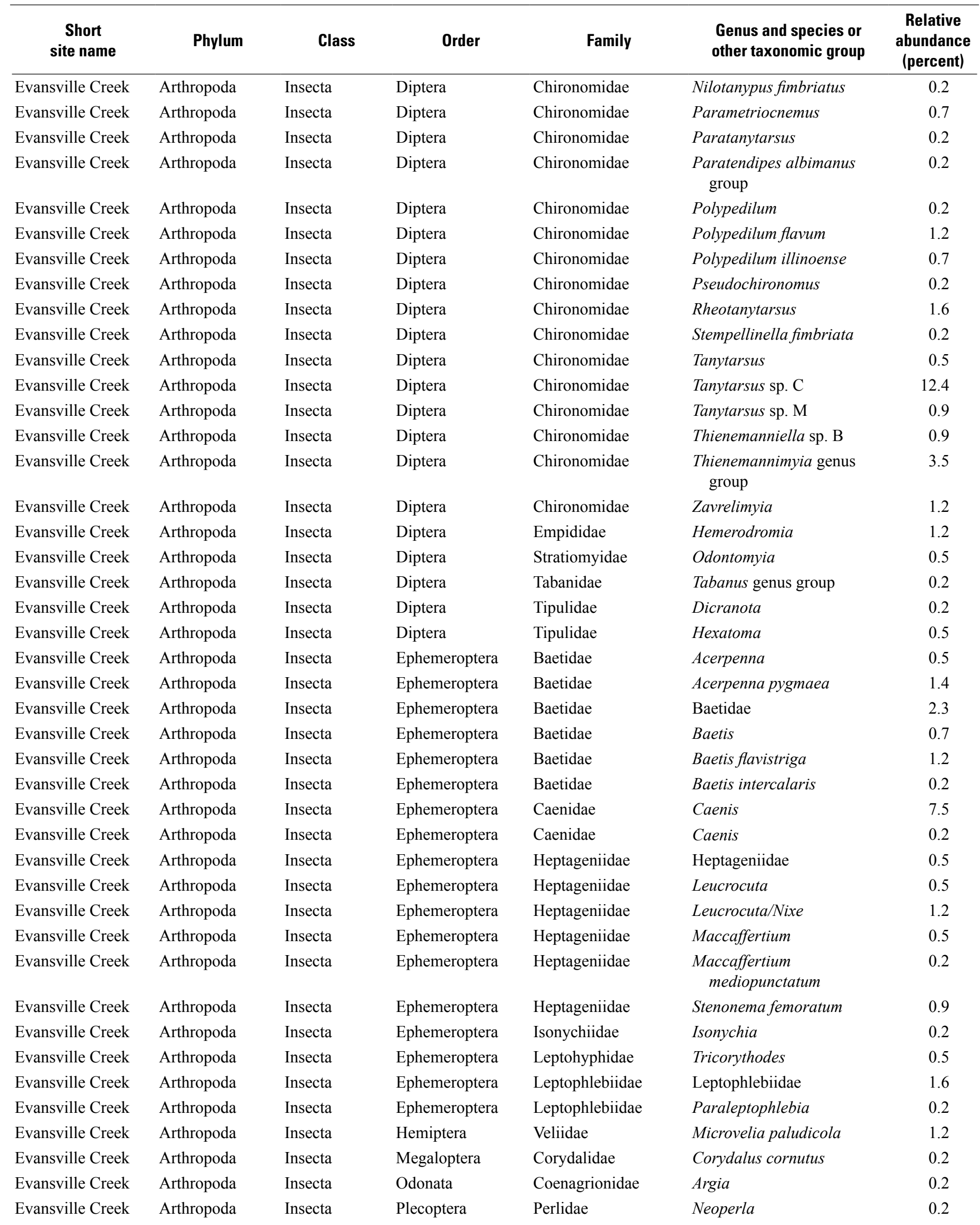


Table 13. List of macroinvertebrate taxa and relative abundances for sampling sites in the Illinois River Basin study area.—Continued

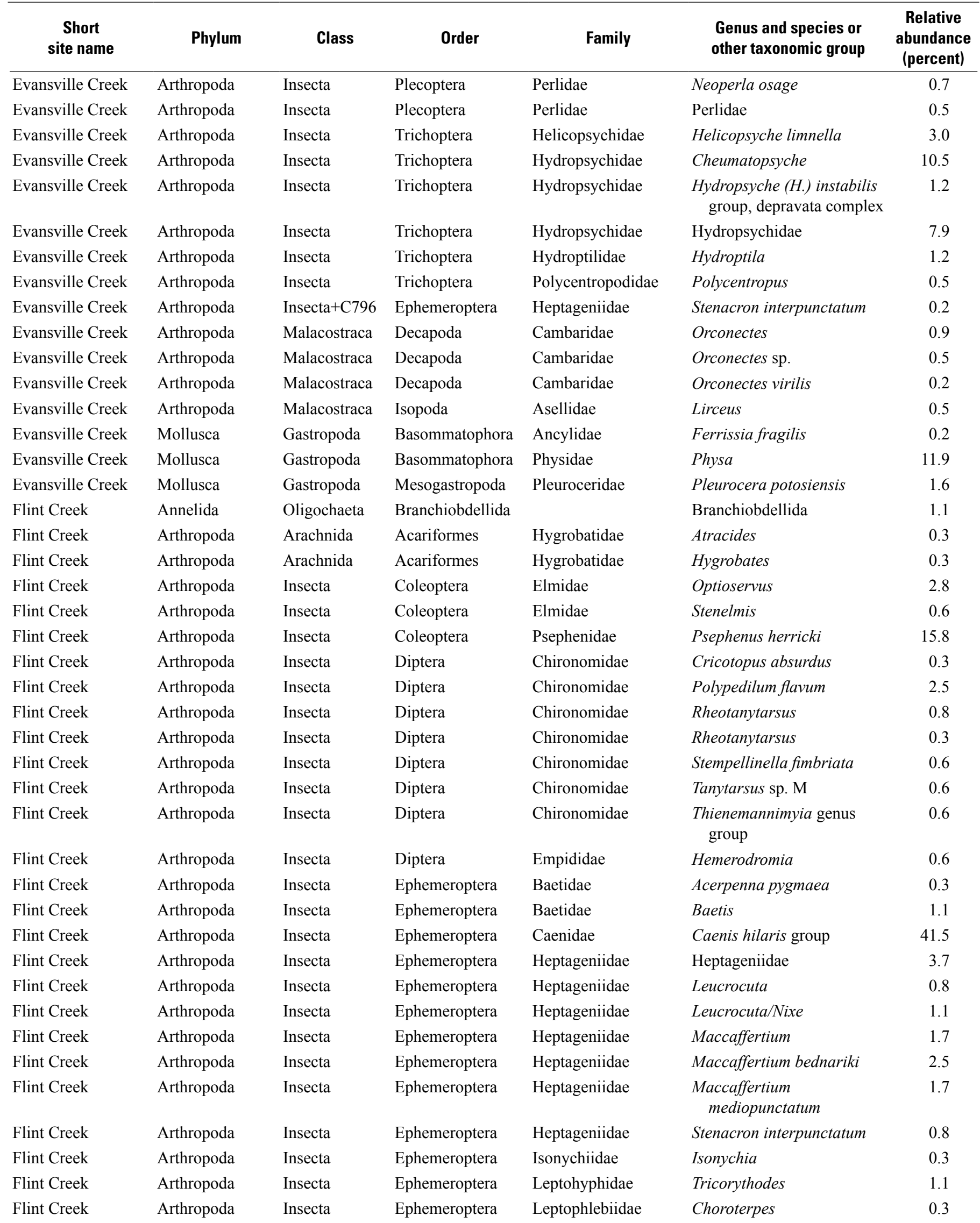


Table 13. List of macroinvertebrate taxa and relative abundances for sampling sites in the Illinois River Basin study area.—Continued

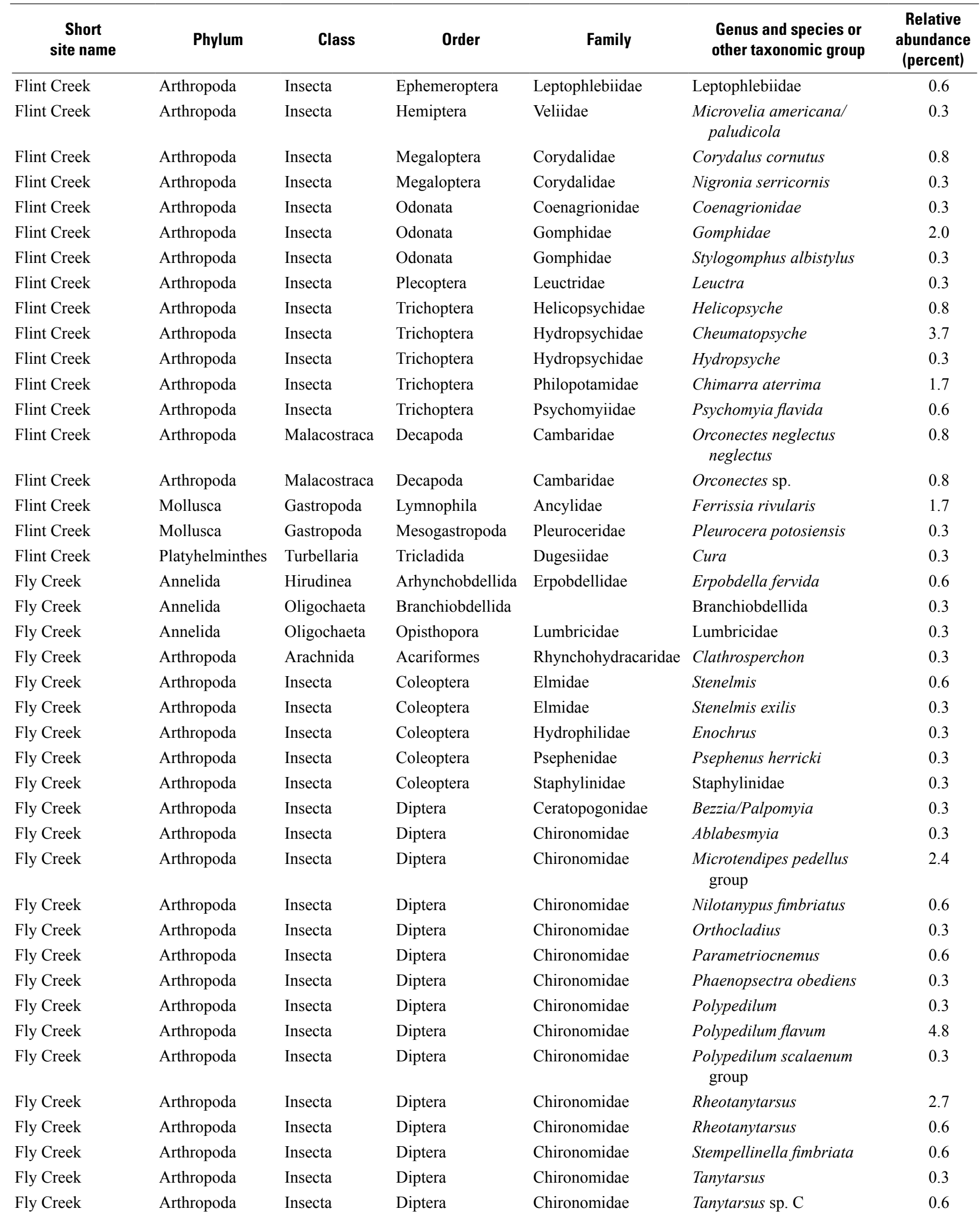


Table 13. List of macroinvertebrate taxa and relative abundances for sampling sites in the Illinois River Basin study area.—Continued

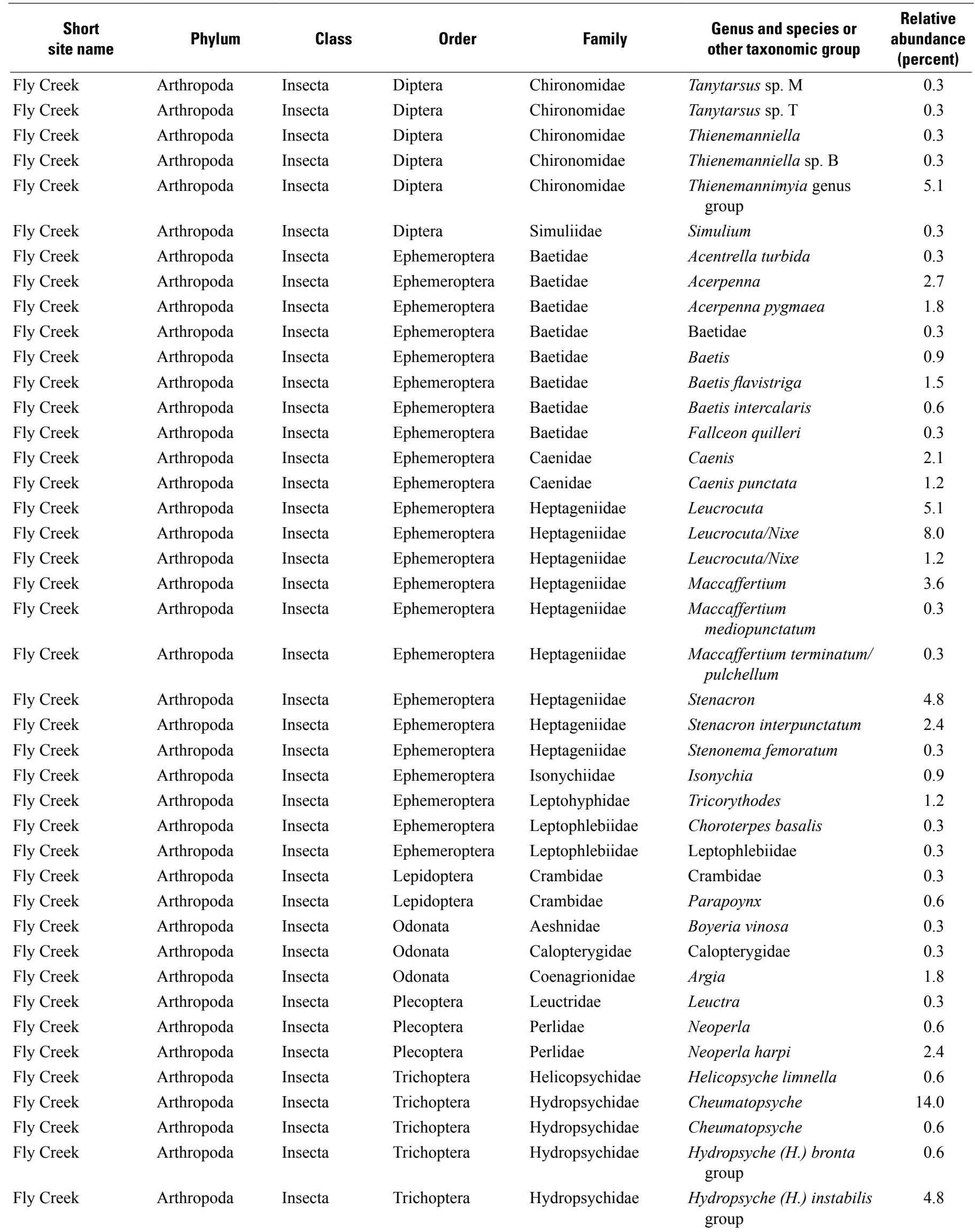


Table 13. List of macroinvertebrate taxa and relative abundances for sampling sites in the Illinois River Basin study area.—Continued

\begin{tabular}{|c|c|c|c|c|c|c|}
\hline $\begin{array}{c}\text { Short } \\
\text { site name }\end{array}$ & Phylum & Class & Order & Family & $\begin{array}{l}\text { Genus and species or } \\
\text { other taxonomic group }\end{array}$ & $\begin{array}{c}\text { Relative } \\
\text { abundance } \\
\text { (percent) }\end{array}$ \\
\hline Fly Creek & Arthropoda & Insecta & Trichoptera & Hydropsychidae & Hydropsychidae & 1.5 \\
\hline Fly Creek & Arthropoda & Insecta & Trichoptera & Polycentropodidae & Polycentropus & 2.1 \\
\hline Fly Creek & Arthropoda & Insecta & Trichoptera & Psychomyiidae & Psychomyia flavida & 0.3 \\
\hline Fly Creek & Arthropoda & Malacostraca & Decapoda & Cambaridae & Orconectes & 0.3 \\
\hline Fly Creek & Arthropoda & Malacostraca & Decapoda & Cambaridae & Orconectes virilis & 0.3 \\
\hline Fly Creek & Arthropoda & Malacostraca & Isopoda & Asellidae & Lirceus & 0.9 \\
\hline Fly Creek & Mollusca & Gastropoda & Basommatophora & Physidae & Physa & 0.9 \\
\hline Fly Creek & Platyhelminthes & Turbellaria & Tricladida & Dugesiidae & Cura & 0.3 \\
\hline Goose Creek & Arthropoda & Insecta & Coleoptera & Psephenidae & Psephenus herricki & 1.3 \\
\hline Goose Creek & Arthropoda & Insecta & Diptera & Chironomidae & $\begin{array}{l}\text { Cricotopus triannulatus/ } \\
\text { infuscatus }\end{array}$ & 0.3 \\
\hline Goose Creek & Arthropoda & Insecta & Diptera & Chironomidae & Cricotopus trifascia & 1.6 \\
\hline Goose Creek & Arthropoda & Insecta & Diptera & Chironomidae & Nilotanypus fimbriatus & 0.3 \\
\hline Goose Creek & Arthropoda & Insecta & Diptera & Chironomidae & Polypedilum flavum & 25.2 \\
\hline Goose Creek & Arthropoda & Insecta & Diptera & Chironomidae & Polypedilum obtusum & 1.6 \\
\hline Goose Creek & Arthropoda & Insecta & Diptera & Chironomidae & Rheotanytarsus & 16.6 \\
\hline Goose Creek & Arthropoda & Insecta & Diptera & Chironomidae & Stempellinella fimbriata & 0.6 \\
\hline Goose Creek & Arthropoda & Insecta & Diptera & Chironomidae & Tanytarsus & 0.3 \\
\hline Goose Creek & Arthropoda & Insecta & Ephemeroptera & Baetidae & Baetidae & 1.9 \\
\hline Goose Creek & Arthropoda & Insecta & Ephemeroptera & Baetidae & Baetis & 10.2 \\
\hline Goose Creek & Arthropoda & Insecta & Ephemeroptera & Baetidae & Baetis flavistriga & 2.2 \\
\hline Goose Creek & Arthropoda & Insecta & Ephemeroptera & Baetidae & Baetis intercalaris & 4.2 \\
\hline Goose Creek & Arthropoda & Insecta & Ephemeroptera & Caenidae & Caenis & 1.0 \\
\hline Goose Creek & Arthropoda & Insecta & Ephemeroptera & Heptageniidae & Maccaffertium & 1.3 \\
\hline Goose Creek & Arthropoda & Insecta & Ephemeroptera & Isonychiidae & Isonychia & 0.6 \\
\hline Goose Creek & Arthropoda & Insecta & Odonata & Coenagrionidae & Argia & 1.0 \\
\hline Goose Creek & Arthropoda & Insecta & Trichoptera & Hydropsychidae & Cheumatopsyche & 11.5 \\
\hline Goose Creek & Arthropoda & Insecta & Trichoptera & Hydropsychidae & $\begin{array}{l}\text { Hydropsyche depravata } \\
\text { complex }\end{array}$ & 1.3 \\
\hline Goose Creek & Arthropoda & Insecta & Trichoptera & Hydropsychidae & Hydropsychidae & 1.6 \\
\hline Goose Creek & Arthropoda & Insecta & Trichoptera & Hydroptilidae & Hydroptila & 3.8 \\
\hline Goose Creek & Arthropoda & Insecta & Trichoptera & Philopotamidae & Chimarra aterrima & 1.9 \\
\hline Goose Creek & Arthropoda & Insecta & Trichoptera & Philopotamidae & Chimarra socia & 0.3 \\
\hline Goose Creek & Nemertea & Enopla & Hoplonemertea & Tetrastemmatidae & Prostoma & 0.3 \\
\hline Goose Creek & Platyhelminthes & Turbellaria & Tricladida & Dugesiidae & Dugesiidae & 1.0 \\
\hline
\end{tabular}


Table 13. List of macroinvertebrate taxa and relative abundances for sampling sites in the Illinois River Basin study area.—Continued

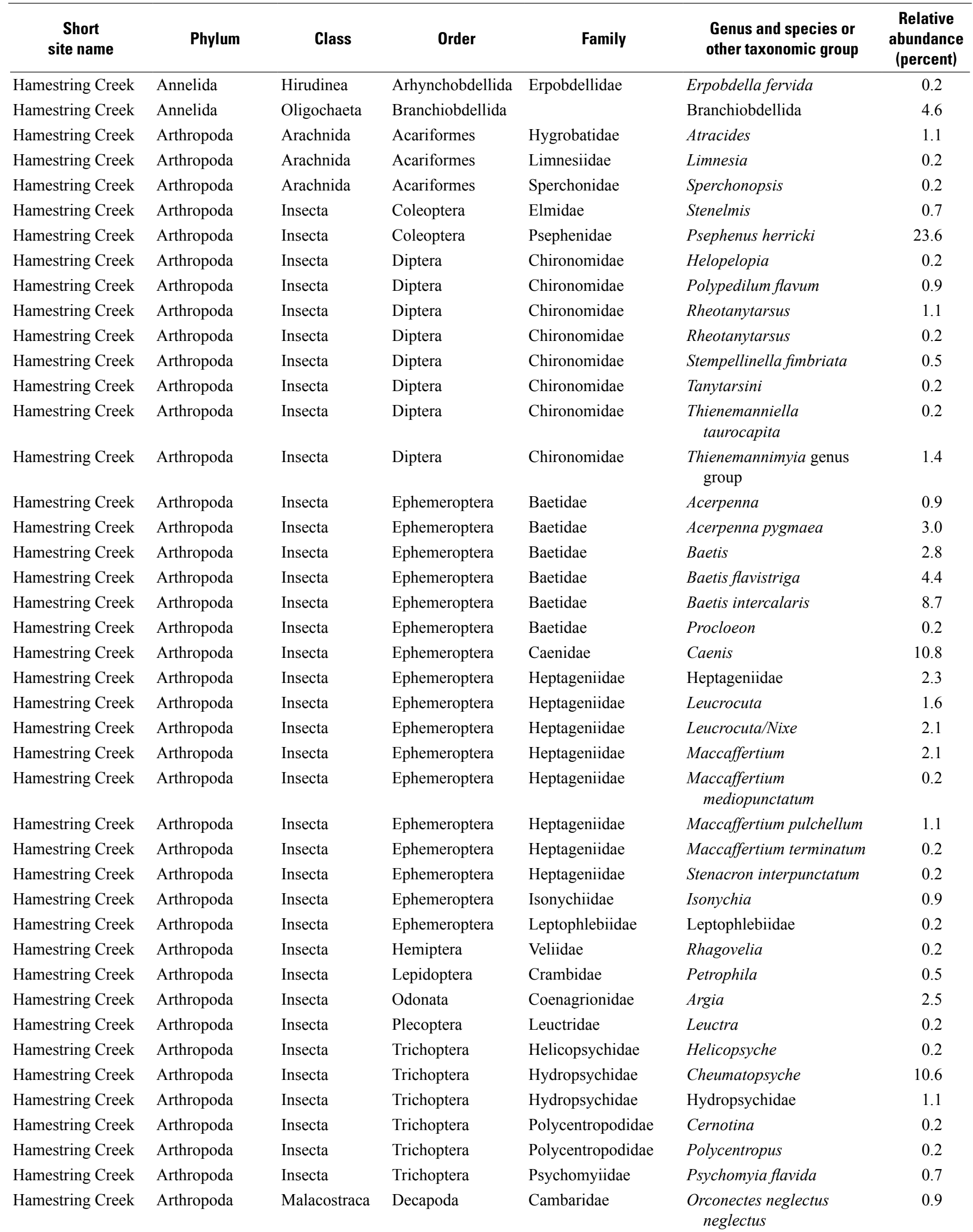


Table 13. List of macroinvertebrate taxa and relative abundances for sampling sites in the Illinois River Basin study area.—Continued

\begin{tabular}{|c|c|c|c|c|c|c|}
\hline $\begin{array}{c}\text { Short } \\
\text { site name }\end{array}$ & Phylum & Class & Order & Family & $\begin{array}{l}\text { Genus and species or } \\
\text { other taxonomic group }\end{array}$ & $\begin{array}{c}\text { Relative } \\
\text { abundance } \\
\text { (percent) }\end{array}$ \\
\hline Hamestring Creek & Arthropoda & Malacostraca & Decapoda & Cambaridae & Orconectes sp. & 3.0 \\
\hline Hamestring Creek & Mollusca & Gastropoda & Mesogastropoda & Pleuroceridae & Pleurocera potosiensis & 0.9 \\
\hline Hamestring Creek & Nemertea & Enopla & Hoplonemertea & Tetrastemmatidae & Prostoma & 0.2 \\
\hline Hamestring Creek & Platyhelminthes & Turbellaria & Tricladida & Dugesiidae & Cura & 0.7 \\
\hline Illinois River & Annelida & Hirudinea & Arhynchobdellida & Erpobdellidae & Erpobdella fervida & 0.6 \\
\hline Illinois River & Annelida & Oligochaeta & Tubificida & Naididae (Naidinae) & Nais communis & 2.0 \\
\hline Illinois River & Annelida & Oligochaeta & Tubificida & Naididae (Naidinae) & Slavina appendiculata & 0.6 \\
\hline Illinois River & Annelida & Oligochaeta & Tubificida & Naididae (Tubificinae) & Limnodrilus hoffmeisteri & 0.3 \\
\hline Illinois River & Arthropoda & Insecta & Coleoptera & Elmidae & Stenelmis & 0.9 \\
\hline Illinois River & Arthropoda & Insecta & Diptera & Ceratopogonidae & Ceratopogonidae & 0.3 \\
\hline Illinois River & Arthropoda & Insecta & Diptera & Ceratopogonidae & Dasyhelea & 1.4 \\
\hline Illinois River & Arthropoda & Insecta & Diptera & Ceratopogonidae & Mallochohelea & 0.3 \\
\hline Illinois River & Arthropoda & Insecta & Diptera & Chironomidae & Conchapelopia & 0.3 \\
\hline Illinois River & Arthropoda & Insecta & Diptera & Chironomidae & Cricotopus & 1.1 \\
\hline Illinois River & Arthropoda & Insecta & Diptera & Chironomidae & Cricotopus absurdus & 2.0 \\
\hline Illinois River & Arthropoda & Insecta & Diptera & Chironomidae & Dicrotendipes & 0.3 \\
\hline Illinois River & Arthropoda & Insecta & Diptera & Chironomidae & Helopelopia & 0.3 \\
\hline Illinois River & Arthropoda & Insecta & Diptera & Chironomidae & $\begin{array}{l}\text { Microtendipes pedellus } \\
\text { group }\end{array}$ & 0.6 \\
\hline Illinois River & Arthropoda & Insecta & Diptera & Chironomidae & Stempellinella fimbriata & 0.3 \\
\hline Illinois River & Arthropoda & Insecta & Diptera & Chironomidae & Tanytarsus sp. C & 0.6 \\
\hline Illinois River & Arthropoda & Insecta & Diptera & Chironomidae & Thienemanniella sp. B & 0.6 \\
\hline Illinois River & Arthropoda & Insecta & Diptera & Chironomidae & $\begin{array}{l}\text { Thienemannimyia genus } \\
\text { group }\end{array}$ & 4.3 \\
\hline Illinois River & Arthropoda & Insecta & Diptera & Empididae & Hemerodromia & 2.3 \\
\hline Illinois River & Arthropoda & Insecta & Diptera & Tabanidae & Tabanus genus group & 0.6 \\
\hline Illinois River & Arthropoda & Insecta & Ephemeroptera & Baetidae & Acentrella & 0.3 \\
\hline Illinois River & Arthropoda & Insecta & Ephemeroptera & Baetidae & Acentrella parvula & 0.3 \\
\hline Illinois River & Arthropoda & Insecta & Ephemeroptera & Baetidae & Acerpenna & 1.1 \\
\hline Illinois River & Arthropoda & Insecta & Ephemeroptera & Baetidae & Acerpenna pygmaea & 4.9 \\
\hline Illinois River & Arthropoda & Insecta & Ephemeroptera & Baetidae & Baetidae & 0.3 \\
\hline Illinois River & Arthropoda & Insecta & Ephemeroptera & Baetidae & Baetis & 0.9 \\
\hline Illinois River & Arthropoda & Insecta & Ephemeroptera & Baetidae & Baetis flavistriga & 2.6 \\
\hline Illinois River & Arthropoda & Insecta & Ephemeroptera & Baetidae & Baetis intercalaris & 2.6 \\
\hline Illinois River & Arthropoda & Insecta & Ephemeroptera & Baetidae & Diphetor hageni & 0.3 \\
\hline Illinois River & Arthropoda & Insecta & Ephemeroptera & Caenidae & Caenis & 4.3 \\
\hline Illinois River & Arthropoda & Insecta & Ephemeroptera & Caenidae & Caenis amica & 2.3 \\
\hline
\end{tabular}


Table 13. List of macroinvertebrate taxa and relative abundances for sampling sites in the Illinois River Basin study area.-Continued

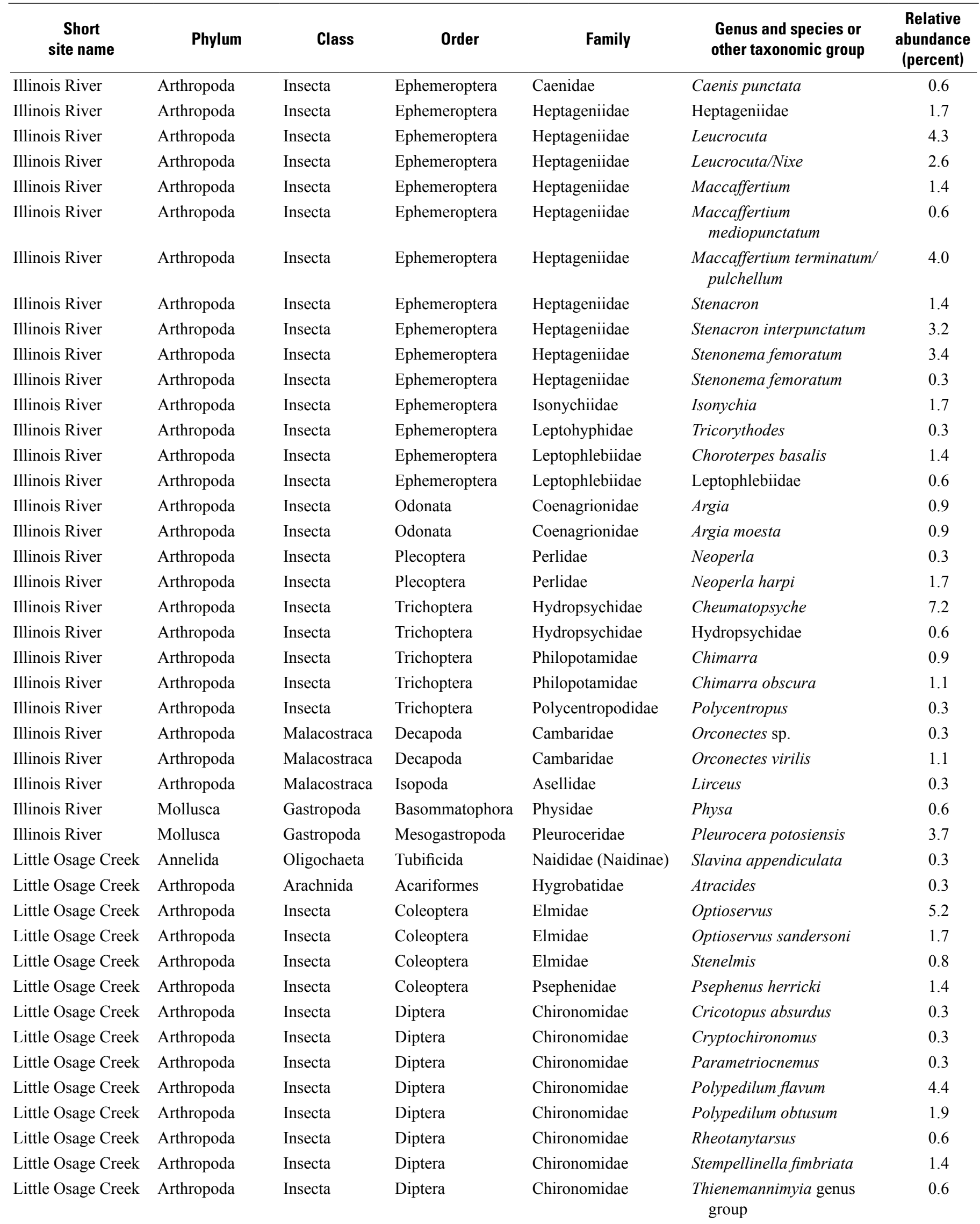


Table 13. List of macroinvertebrate taxa and relative abundances for sampling sites in the Illinois River Basin study area.—Continued

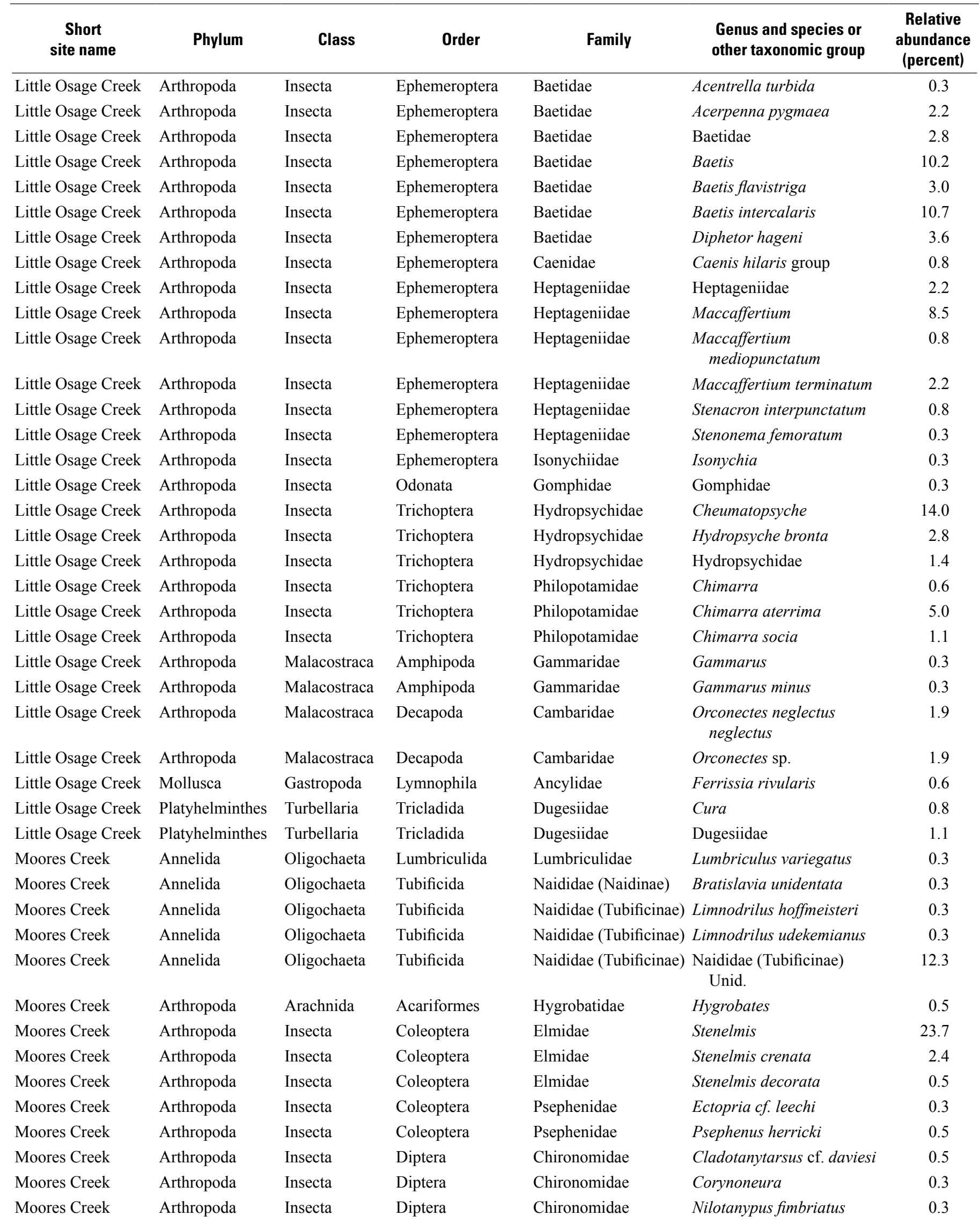


Table 13. List of macroinvertebrate taxa and relative abundances for sampling sites in the Illinois River Basin study area.—Continued

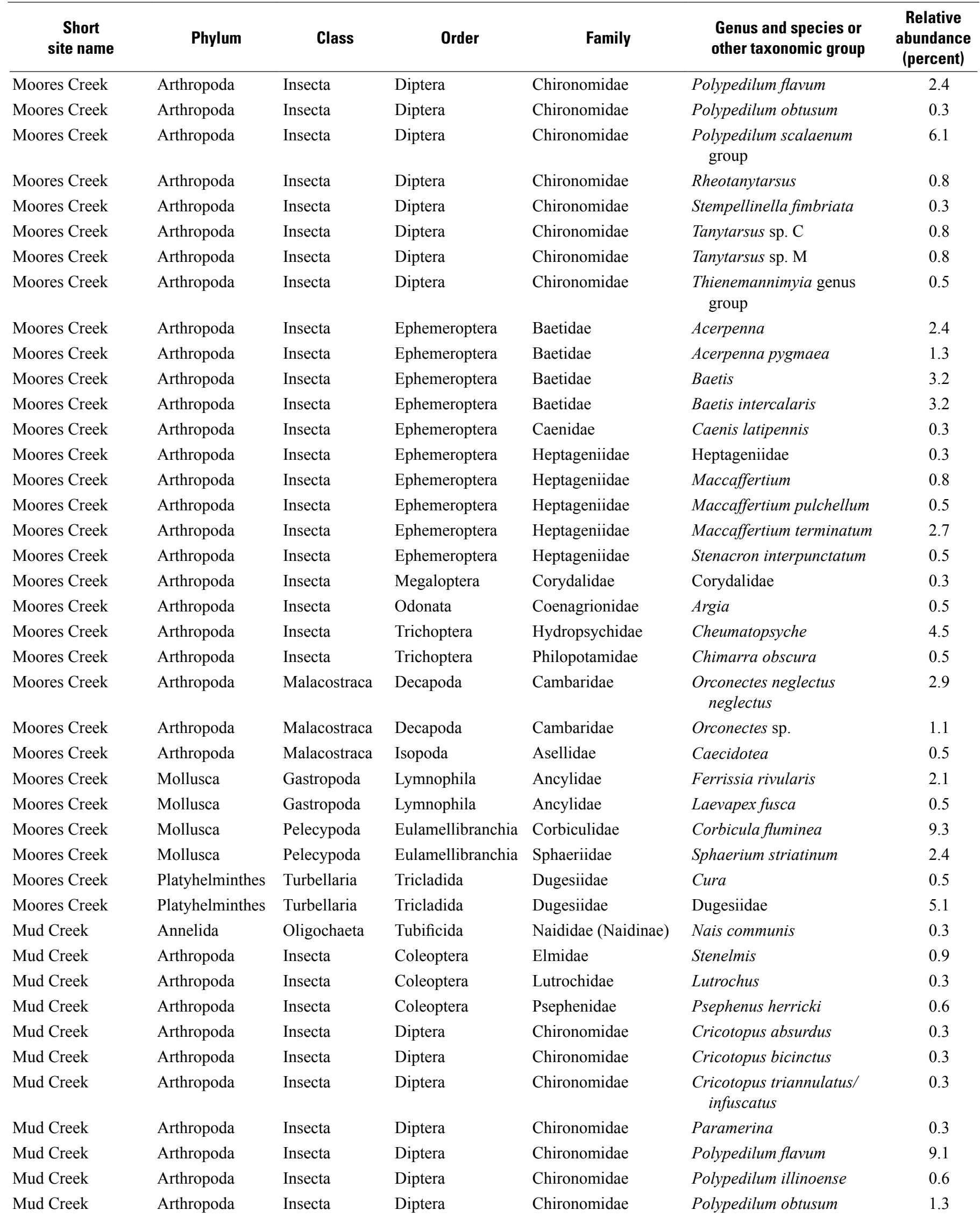


Table 13. List of macroinvertebrate taxa and relative abundances for sampling sites in the Illinois River Basin study area.—Continued

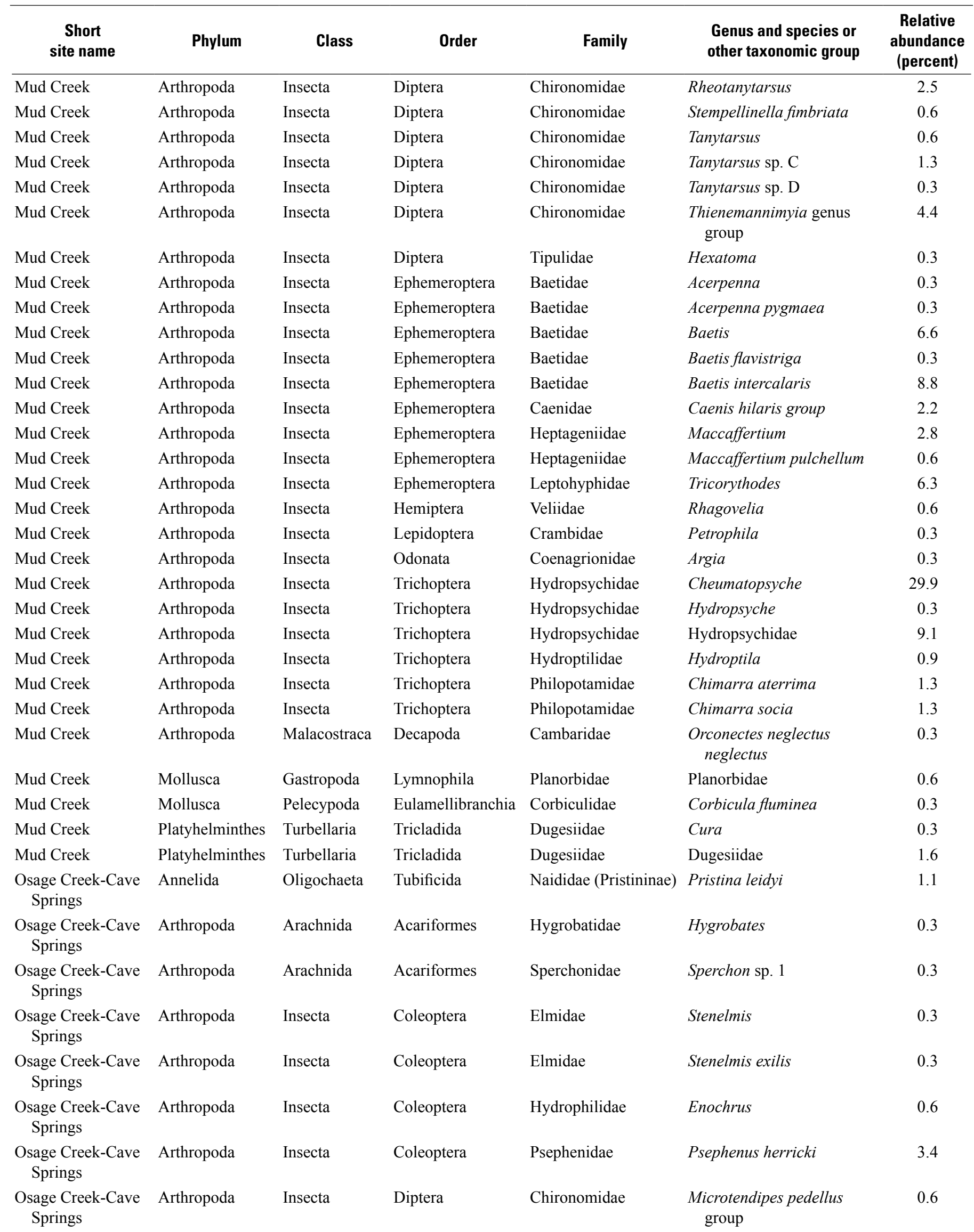


Table 13

Table 13. List of macroinvertebrate taxa and relative abundances for sampling sites in the Illinois River Basin study area.-Continued

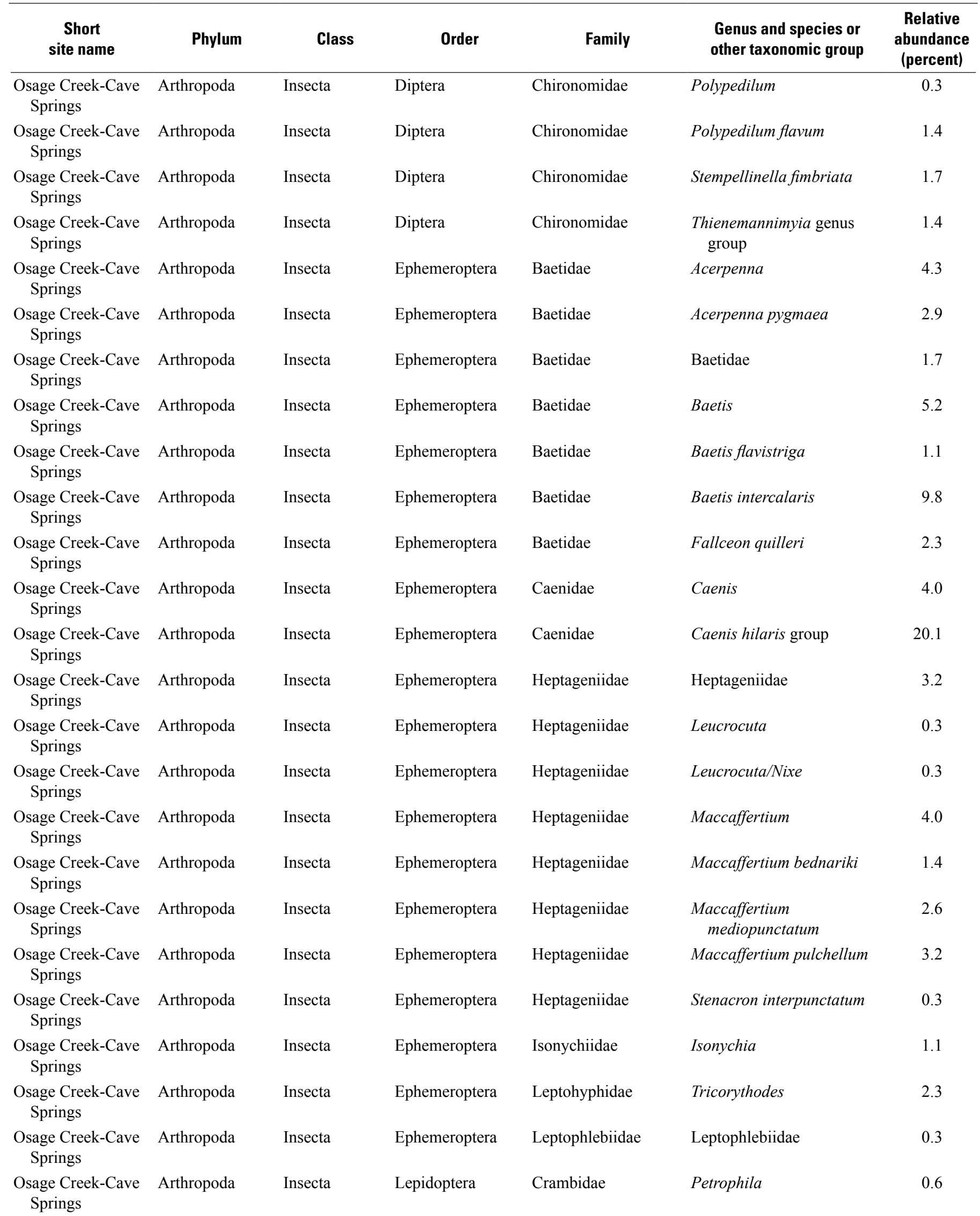


Table 13. List of macroinvertebrate taxa and relative abundances for sampling sites in the Illinois River Basin study area.-Continued

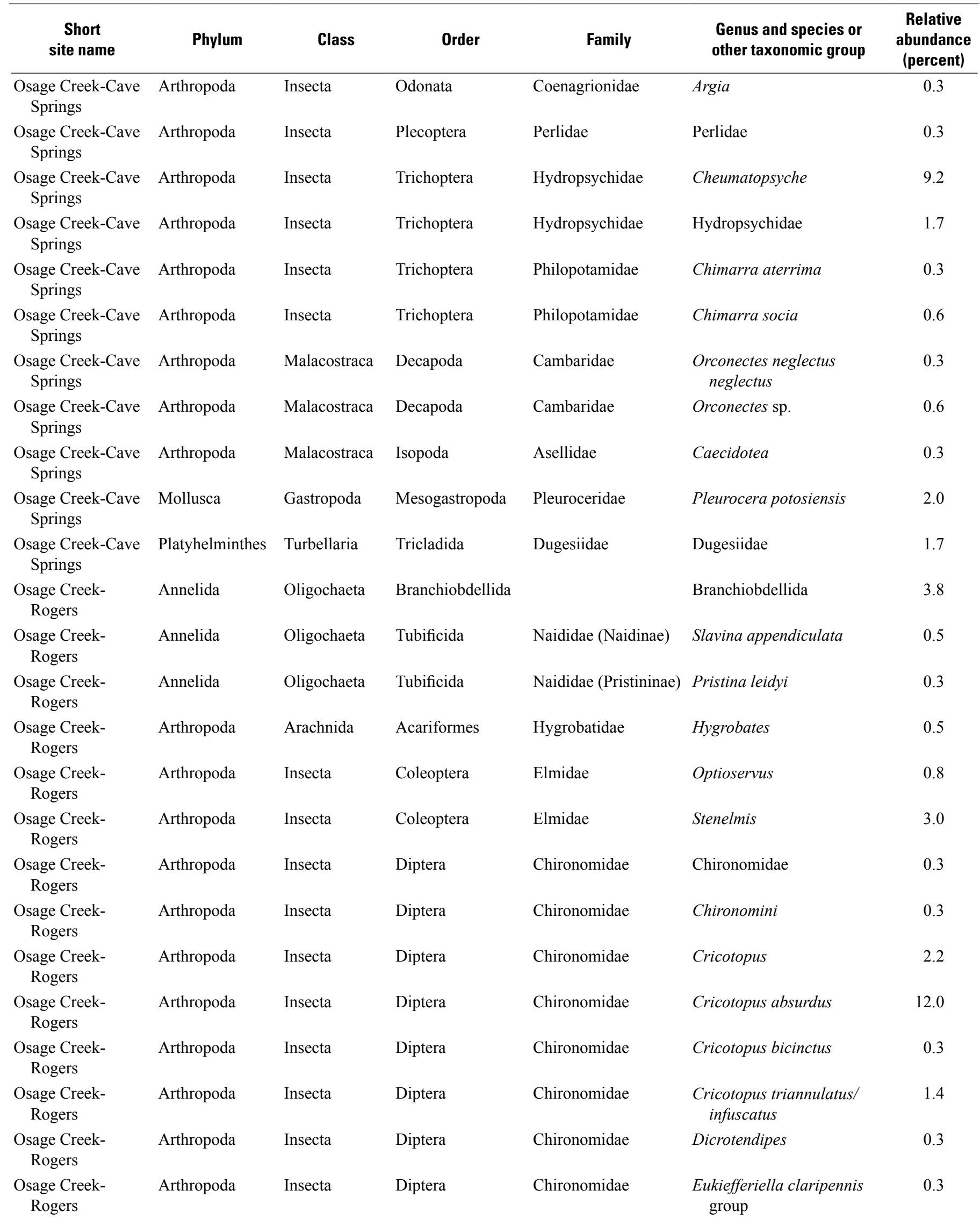


Table 13

Table 13. List of macroinvertebrate taxa and relative abundances for sampling sites in the Illinois River Basin study area.-Continued

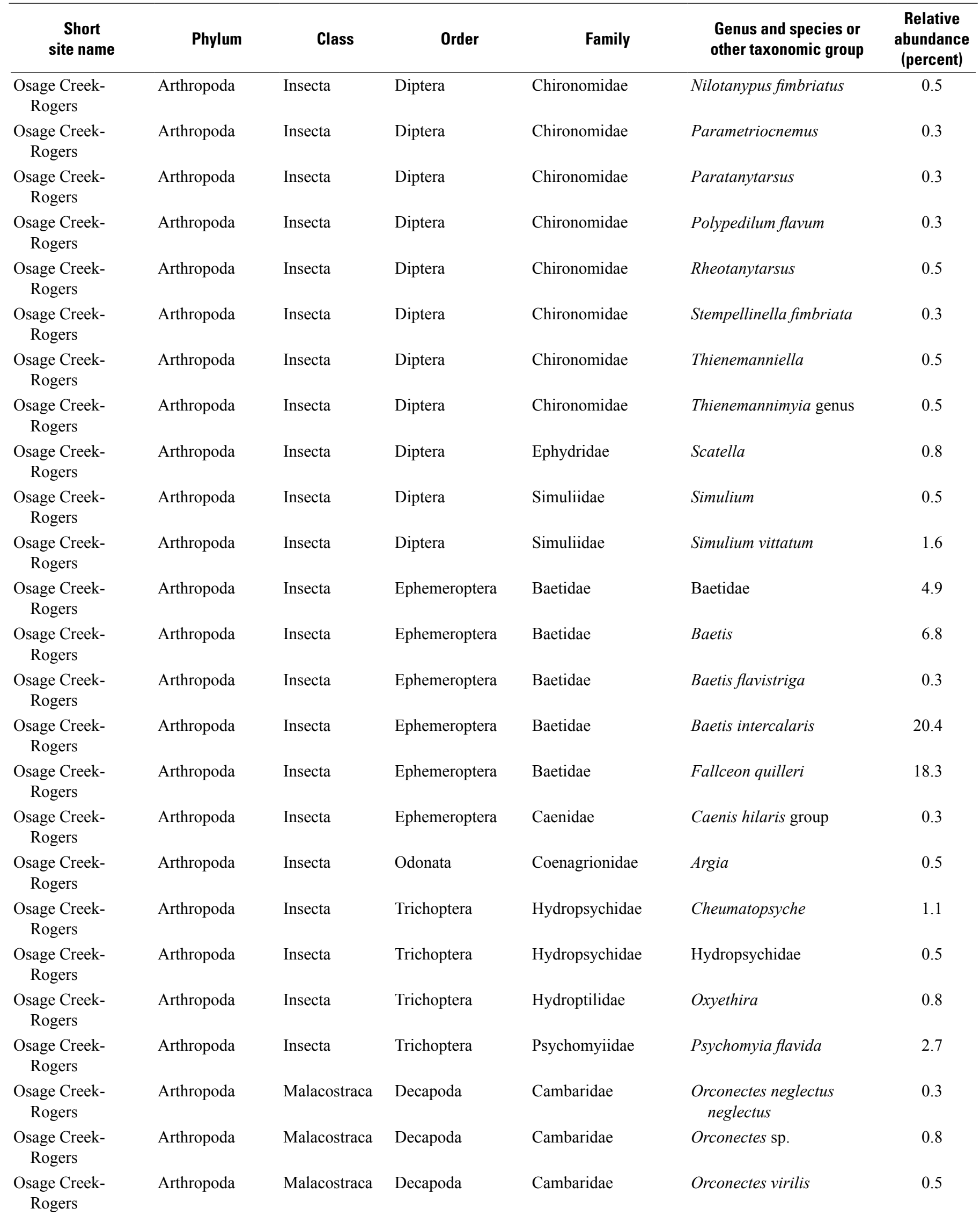


Table 13. List of macroinvertebrate taxa and relative abundances for sampling sites in the Illinois River Basin study area.—Continued

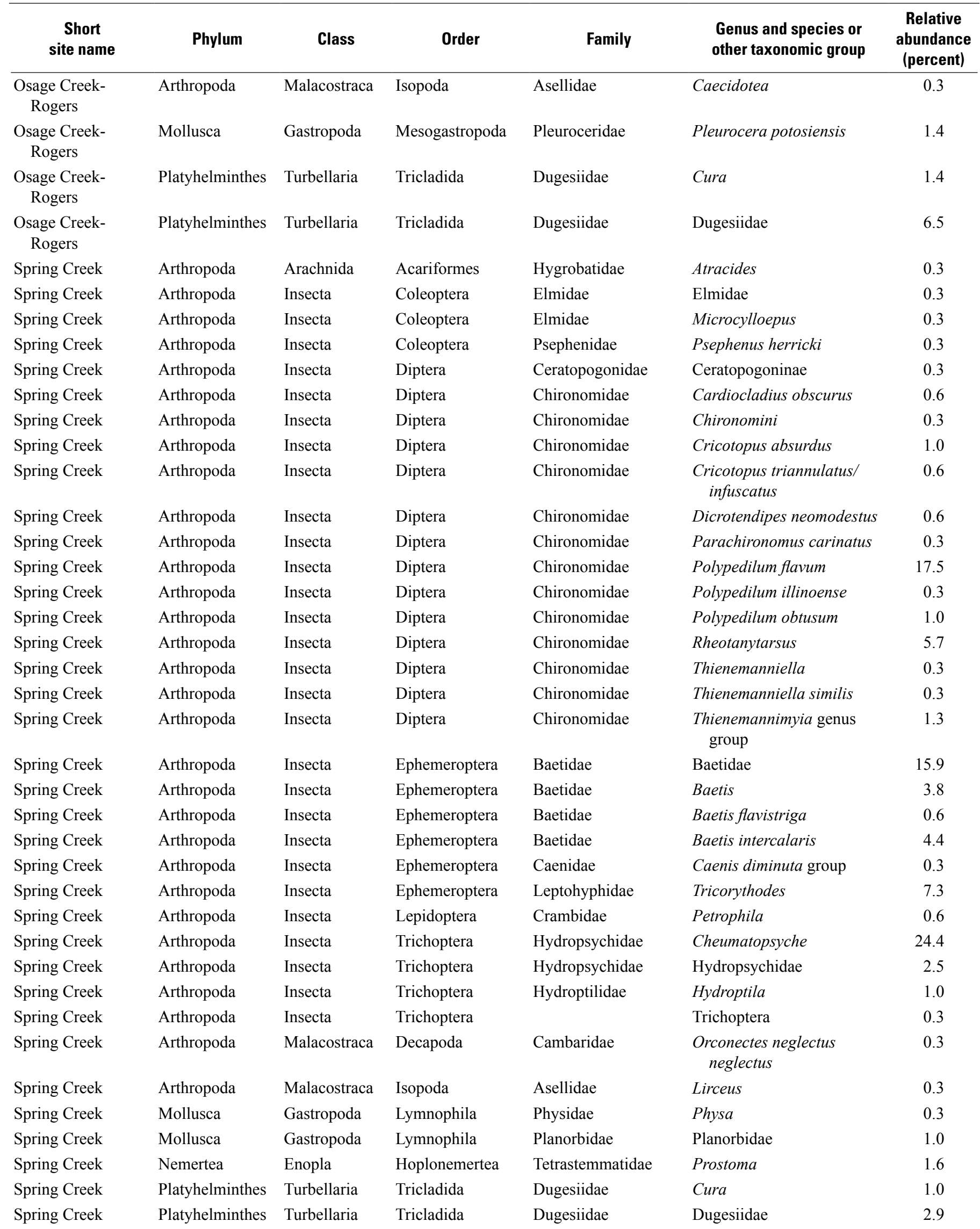


Table 13. List of macroinvertebrate taxa and relative abundances for sampling sites in the Illinois River Basin study area.—Continued

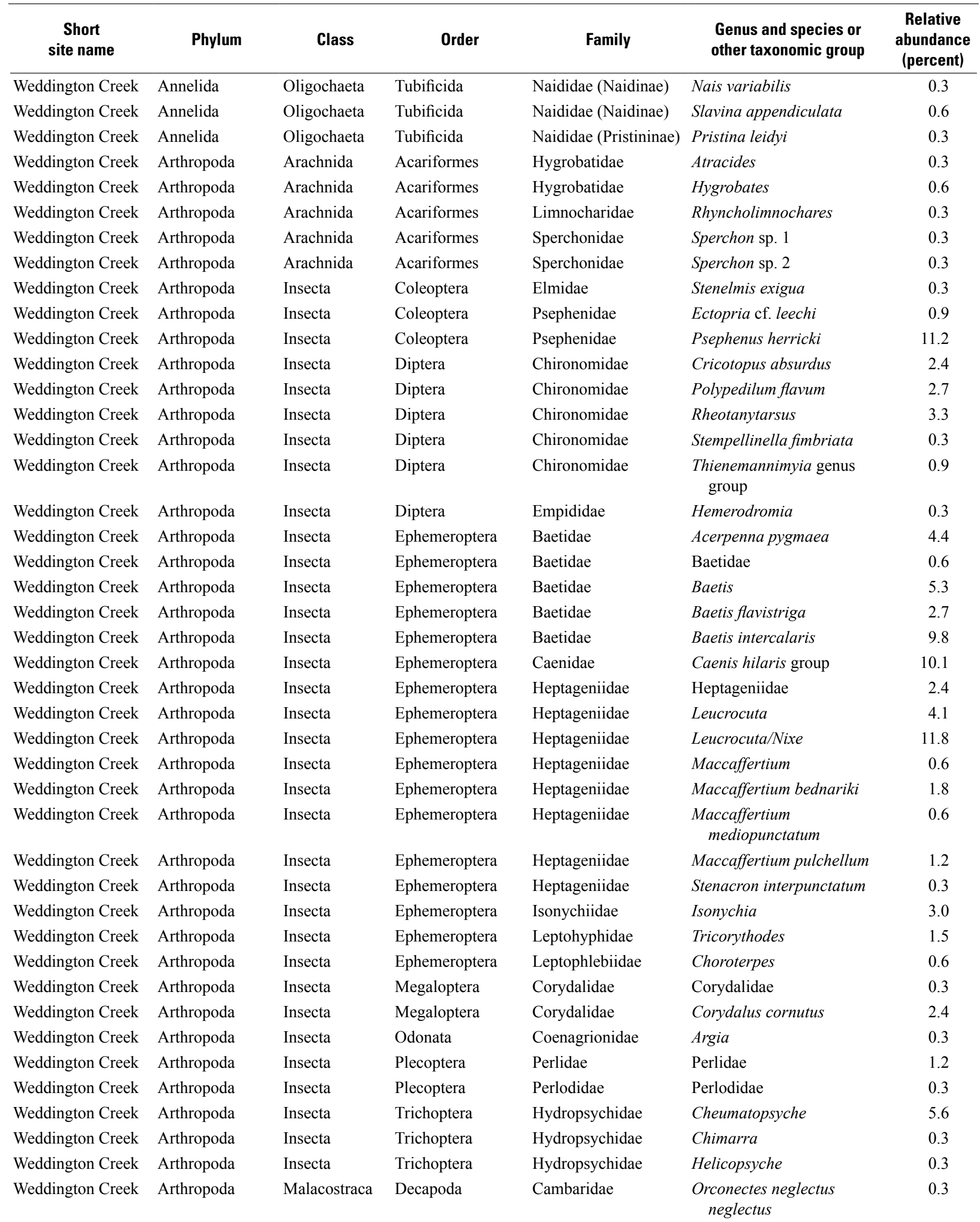


Table 13. List of macroinvertebrate taxa and relative abundances for sampling sites in the Illinois River Basin study area.—Continued

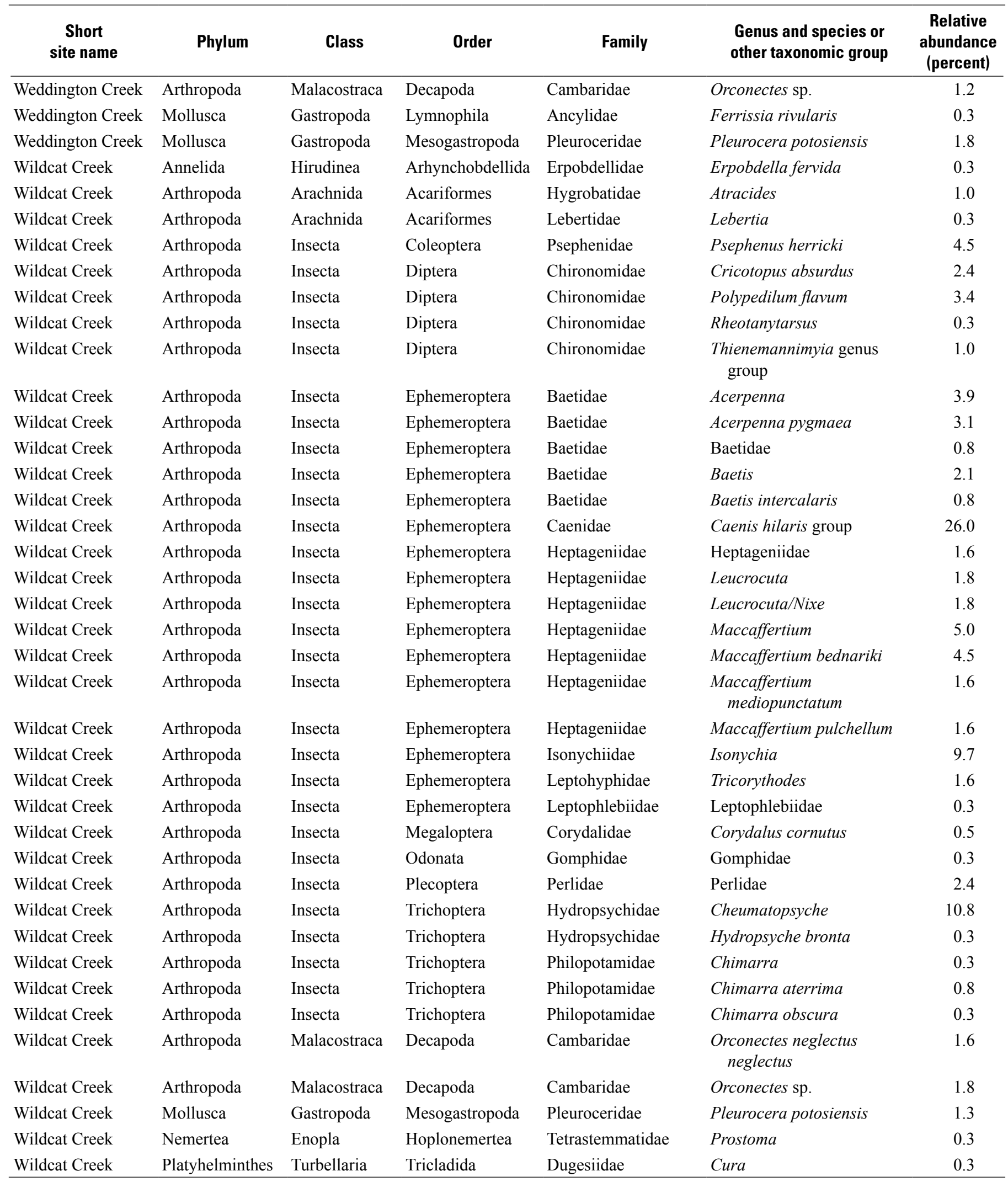


Table 14. Macroinvertebrate metric and index scores for sampling sites in the Illinois River Basin study area.

[Sites are sorted by index score, which is rounded to nearest whole number; EPT, Ephemeroptera, Plecoptera, Trichoptera; richness, number of taxa; Metric scores are associated with metric in preceding column and range from 0 to 100, with 100 indicating least degraded condition]

\begin{tabular}{|c|c|c|c|c|c|c|c|c|c|c|c|c|}
\hline $\begin{array}{c}\text { Short } \\
\text { site name }\end{array}$ & $\begin{array}{l}\text { EPT } \\
\text { rich- } \\
\text { ness }\end{array}$ & $\begin{array}{l}\text { Metric } \\
\text { score }\end{array}$ & $\begin{array}{c}\text { Percent } \\
\text { predator } \\
\text { rich- } \\
\text { ness }\end{array}$ & $\begin{array}{l}\text { Metric } \\
\text { score }\end{array}$ & $\begin{array}{l}\text { Percent } \\
\text { gatherer- } \\
\text { collec- } \\
\text { tors }\end{array}$ & $\begin{array}{l}\text { Metric } \\
\text { score }\end{array}$ & $\begin{array}{l}\text { Margalef } \\
\text { diversity }\end{array}$ & $\begin{array}{l}\text { Metric } \\
\text { score }\end{array}$ & $\begin{array}{c}\text { Per- } \\
\text { cent } \\
\text { Baeti- } \\
\text { dae }\end{array}$ & $\begin{array}{l}\text { Metric } \\
\text { score }\end{array}$ & $\begin{array}{c}\text { Macro- } \\
\text { inver- } \\
\text { tebrate } \\
\text { index } \\
\text { score }^{1}\end{array}$ & $\begin{array}{c}\text { Macroinverte- } \\
\text { brate } \\
\text { index } \\
\text { class }\end{array}$ \\
\hline Fly Creek ${ }^{2}$ & 32 & 100.0 & 15.3 & 52.9 & 17.0 & 90.3 & 28.1 & 100.0 & 8.3 & 84.5 & 86 & Least impaired \\
\hline Illinois River ${ }^{3}$ & 32 & 100.0 & 19.4 & 67.2 & 21.0 & 77.8 & 26.0 & 86.9 & 13.2 & 74.7 & 81 & Least impaired \\
\hline Baron Fork ${ }^{2}$ & 20 & 45.5 & 23.4 & 81.1 & 13.9 & 100.0 & 24.6 & 78.7 & 0.6 & 100.0 & 81 & Least impaired \\
\hline Ballard Creek ${ }^{2}$ & 18 & 36.4 & 16.4 & 56.7 & 22.1 & 74.2 & 22.7 & 67.0 & 2.3 & 96.5 & 66 & Good \\
\hline $\begin{array}{c}\text { Weddington } \\
\text { Creek }^{2}\end{array}$ & 22 & 54.6 & 22.2 & 76.9 & 23.4 & 70.3 & 17.8 & 36.5 & 22.8 & 55.7 & 59 & Good \\
\hline Wildcat Creek ${ }^{2}$ & 22 & 54.6 & 16.7 & 57.7 & 32.5 & 41.5 & 13.9 & 12.8 & 10.8 & 79.6 & 49 & Fair \\
\hline Flint Creek ${ }^{2}$ & 20 & 45.5 & 18.2 & 62.9 & 45.8 & -0.0 & 16.9 & 30.8 & 1.4 & 98.3 & 47 & Fair \\
\hline Mud Creek ${ }^{4}$ & 15 & 22.7 & 9.8 & 33.8 & 22.3 & 73.5 & 16.0 & 25.4 & 16.4 & 68.5 & 45 & Fair \\
\hline Moores Creek ${ }^{2}$ & 12 & 9.1 & 8.9 & 30.8 & 24.0 & 68.3 & 17.1 & 32.2 & 10.1 & 80.9 & 44 & Fair \\
\hline Spring Creek ${ }^{4}$ & 10 & 0.0 & 8.3 & 28.8 & 34.6 & 35.0 & 14.0 & 13.2 & 24.8 & 51.7 & 26 & Poor \\
\hline $\begin{array}{l}\text { Osage Creek- } \\
\text { Rogers }\end{array}$ & 10 & 0.0 & 7.0 & 24.2 & 42.0 & 11.9 & 16.4 & 27.8 & 50.7 & 0.0 & 13 & Poor \\
\hline
\end{tabular}

${ }^{1}$ Index values rounded to nearest whole number.

${ }^{2}$ Agriculture site (Baron Fork and Goose Creek are downstream from wastewater-treatment plants).

${ }^{3}$ Forest site.

${ }^{4}$ Urban site (Osage Creek-Cave Springs and Spring Creek are downstream from wastewater-treatment plants). 
Table 15. List of macroinvertebrate metrics.

[EPT, Ephemeroptera, Plecoptera, Trichoptera; EPA, U.S. Environmental Protection Agency]

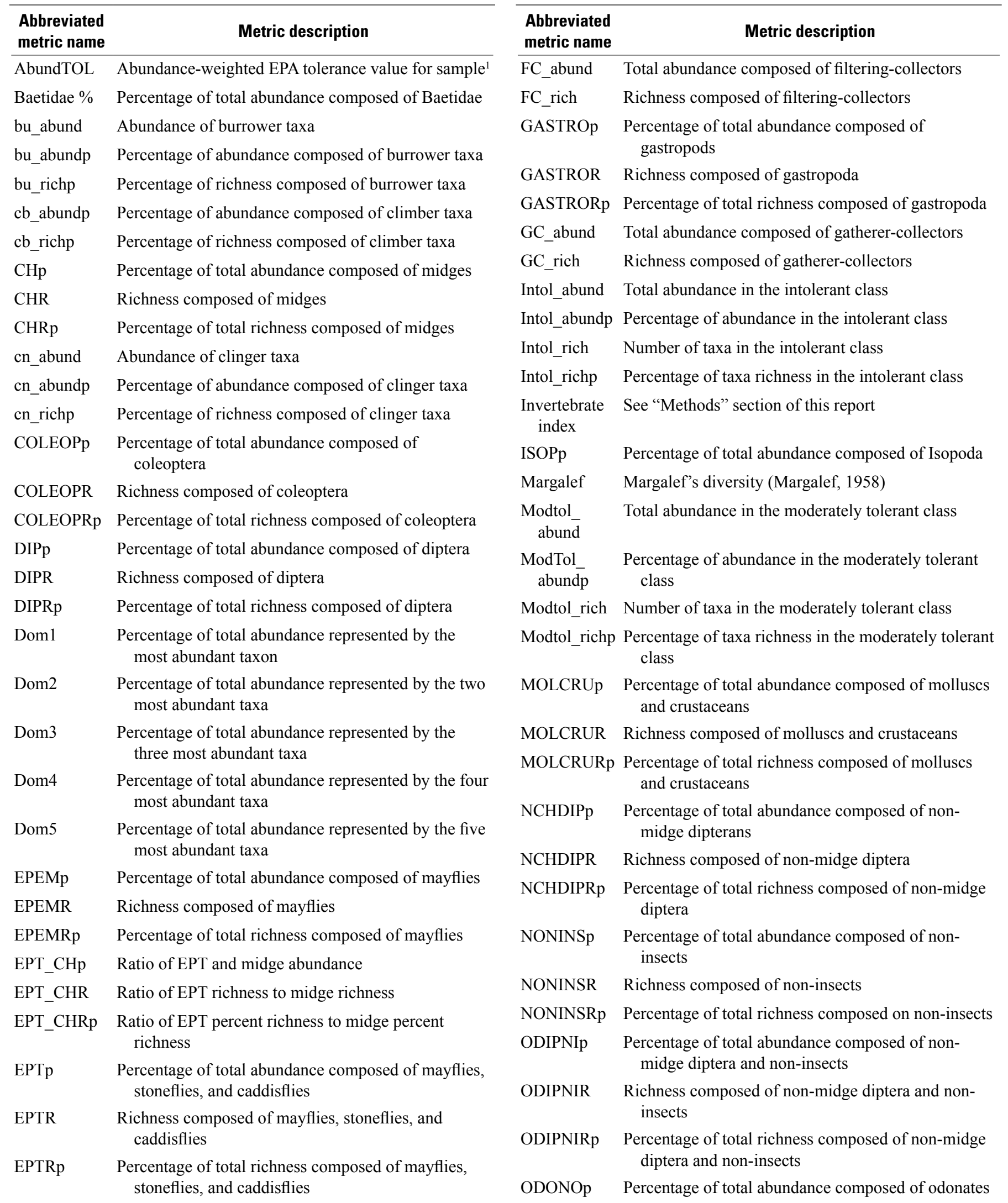


Table 15. List of macroinvertebrate metrics.-Continued

[EPT, Ephemeroptera, Plecoptera, Trichoptera; EPA, U.S. Environmental Protection Agency]

\begin{tabular}{|c|c|}
\hline $\begin{array}{l}\text { Abbreviated } \\
\text { metric name }\end{array}$ & Metric description \\
\hline ODONOR & Richness composed of odonates \\
\hline ODONORp & Percentage of total richness composed of odonates \\
\hline OLIGOp & $\begin{array}{l}\text { Percentage of total abundance composed of } \\
\text { Oligochaeta }\end{array}$ \\
\hline OLIGOR & Richness composed of oligochaeta \\
\hline OLIGORp & Percentage of total richness composed of Oligochaeta \\
\hline OM_abund & Total abundance composed of omnivores \\
\hline OM_rich & Richness composed of omnivores \\
\hline pFC_abund & $\begin{array}{l}\text { Percentage of total abundance composed of filtering- } \\
\text { collectors }\end{array}$ \\
\hline pFC_rich & $\begin{array}{l}\text { Percentage of total richness composed of filtering- } \\
\text { collectors }\end{array}$ \\
\hline pGC_abund & $\begin{array}{l}\text { Percentage of total abundance composed of gatherer- } \\
\text { collectors }\end{array}$ \\
\hline pGC_rich & $\begin{array}{l}\text { Percentage of total richness composed of gatherer- } \\
\text { collectors }\end{array}$ \\
\hline PLECOp & Percentage of total abundance composed of stoneflies \\
\hline PLECOR & Richness composed of stoneflies \\
\hline PLECORp & Percentage of total richness composed of stoneflies \\
\hline pOM_abund & $\begin{array}{l}\text { Percentage of total abundance composed of } \\
\text { omnivores }\end{array}$ \\
\hline pOM_rich & Percentage of total richness composed of omnivores \\
\hline pPR_abund & Percentage of total abundance composed of predators \\
\hline pPR_rich & Percentage of total richness composed of predators \\
\hline PR_abund & Total abundance composed of predators \\
\hline PR_rich & Richness composed of predators \\
\hline
\end{tabular}

\begin{tabular}{|c|c|}
\hline $\begin{array}{l}\text { Abbreviated } \\
\text { metric name }\end{array}$ & Metric description \\
\hline pSC_abund & $\begin{array}{l}\text { Percentage of total abundance composed of } \\
\text { scrapers }\end{array}$ \\
\hline pSC_rich & Percentage of total richness composed of scrapers \\
\hline pSH_abund & Percentage of total abundance composed of shredders \\
\hline pSH_rich & Percentage of total richness composed of shredders \\
\hline RICH & Total richness (number of non-ambiguous taxa) \\
\hline RichTOL & $\begin{array}{l}\text { Average EPA tolerance values for sample based on } \\
\text { richness }\end{array}$ \\
\hline SC_abund & Total abundance composed of scrapers \\
\hline SC_rich & Richness composed of scrapers \\
\hline SH_abund & Total abundance composed of shredders \\
\hline SH_rich & Richness composed of shredders \\
\hline sp_abund & Abundance of sprawler taxa \\
\hline sp_abundp & $\begin{array}{l}\text { Percentage of abundance composed of sprawler } \\
\text { taxa }\end{array}$ \\
\hline sp_richp & Percentage of richness composed of sprawler taxa \\
\hline Tol_abund & Total abundace in the tolerant class \\
\hline Tol_abundp & Percentage of abundance in the tolerant class \\
\hline Tol_rich & Number of taxa in the tolerant class \\
\hline Tol_richp & Percentage of taxa richness in the tolerant class \\
\hline TRICHp & $\begin{array}{l}\text { Percentage of total abundance composed of } \\
\text { caddisflies }\end{array}$ \\
\hline TRICHR & Richness composed of caddisflies \\
\hline TRICHRp & $\begin{array}{l}\text { Percentage of total richness composed of } \\
\text { caddisflies }\end{array}$ \\
\hline
\end{tabular}

${ }^{1}$ EPA tolerance values from Barbour and others (1999). 
Table 16. Correlations between macroinvertebrate metrics and index and selected environmental factors for sites not affected by wastewater-treatment plants.

[Macroinvertebrate metrics are sorted by absolute value of correlation with percent forest; red font denotes absolute value of rho is greater than or equal to 0.50 ; metric abbreviations are listed in table 15 ; number of sites equals 14]

\begin{tabular}{|c|c|c|c|c|c|c|c|c|c|c|c|c|}
\hline & $\begin{array}{c}\text { Nitrite } \\
\text { plus } \\
\text { nitrate }\end{array}$ & $\begin{array}{c}\text { Total } \\
\text { phosphorus }\end{array}$ & $\begin{array}{l}\text { Tempera- } \\
\text { ture }\end{array}$ & $\begin{array}{c}\text { Specific } \\
\text { conduc- } \\
\text { tance }\end{array}$ & $\begin{array}{l}\text { Dissolved } \\
\text { oxygen }\end{array}$ & $\mathrm{pH}$ & Streamflow & $\begin{array}{l}\text { Bankfull } \\
\text { width }\end{array}$ & $\begin{array}{l}\text { Drainage } \\
\text { area }\end{array}$ & $\begin{array}{l}\text { Bankfull } \\
\text { width/ } \\
\text { drainage } \\
\text { area }\end{array}$ & Depth & Velocity \\
\hline PR_rich & -0.30 & -0.17 & 0.32 & -0.32 & 0.17 & -0.14 & -0.56 & 0.62 & -0.03 & 0.20 & -0.58 & -0.54 \\
\hline Macroinvertebrate index & -0.30 & -0.16 & 0.31 & -0.25 & 0.29 & -0.07 & -0.58 & 0.66 & -0.11 & 0.27 & -0.74 & -0.66 \\
\hline PLECOR & -0.02 & -0.16 & 0.11 & -0.24 & 0.07 & -0.21 & -0.42 & 0.49 & -0.14 & 0.23 & -0.40 & -0.26 \\
\hline Margalef diversity & -0.28 & -0.09 & 0.09 & -0.18 & 0.21 & -0.29 & -0.54 & 0.29 & 0.25 & -0.16 & -0.53 & -0.64 \\
\hline $\mathrm{SC}$ _rich & -0.08 & 0.05 & 0.04 & -0.34 & 0.27 & 0.09 & -0.30 & 0.10 & 0.20 & -0.18 & -0.41 & -0.45 \\
\hline pPR_abund & -0.30 & -0.11 & 0.19 & -0.27 & 0.42 & -0.14 & -0.45 & 0.57 & 0.09 & 0.07 & -0.60 & -0.61 \\
\hline PR_abund & -0.34 & -0.14 & 0.22 & -0.32 & 0.40 & -0.10 & -0.47 & 0.56 & 0.06 & 0.10 & -0.57 & -0.61 \\
\hline $\mathrm{RICH}$ & -0.33 & -0.17 & 0.08 & -0.22 & 0.22 & -0.30 & -0.55 & 0.26 & 0.18 & -0.12 & -0.47 & -0.63 \\
\hline PLECORp & 0.06 & -0.03 & 0.11 & -0.20 & 0.08 & -0.10 & -0.31 & 0.47 & -0.08 & 0.19 & -0.34 & -0.23 \\
\hline pPR_rich & -0.12 & -0.03 & 0.37 & -0.30 & 0.13 & 0.07 & -0.27 & 0.55 & -0.11 & 0.23 & -0.28 & -0.24 \\
\hline EPTR & -0.10 & -0.34 & -0.05 & -0.26 & 0.23 & -0.11 & -0.44 & 0.55 & -0.12 & 0.30 & -0.46 & -0.35 \\
\hline PLECOp & 0.15 & -0.07 & 0.03 & -0.18 & 0.24 & -0.09 & -0.31 & 0.57 & -0.14 & 0.28 & -0.47 & -0.24 \\
\hline bu_richp & 0.11 & -0.35 & -0.24 & 0.21 & -0.16 & -0.15 & 0.28 & -0.37 & -0.19 & 0.03 & 0.54 & 0.54 \\
\hline Modtol_rich & -0.50 & -0.09 & 0.39 & -0.16 & -0.04 & -0.17 & -0.68 & 0.26 & 0.12 & -0.03 & -0.63 & -0.77 \\
\hline Dom4 & 0.29 & -0.01 & -0.22 & 0.24 & -0.07 & 0.18 & 0.53 & -0.56 & -0.24 & -0.09 & 0.62 & 0.58 \\
\hline Dom3 & 0.28 & 0.08 & -0.02 & 0.15 & 0.05 & 0.32 & 0.54 & -0.41 & -0.27 & -0.00 & 0.39 & 0.54 \\
\hline Dom5 & 0.22 & -0.08 & -0.14 & 0.17 & -0.10 & 0.16 & 0.45 & -0.52 & -0.32 & -0.02 & 0.56 & 0.55 \\
\hline Dom2 & 0.31 & 0.04 & -0.05 & 0.22 & 0.12 & 0.29 & 0.46 & -0.38 & -0.27 & -0.01 & 0.27 & 0.42 \\
\hline cb_abundp & -0.10 & -0.04 & -0.17 & -0.22 & 0.54 & 0.01 & -0.24 & 0.24 & 0.22 & -0.13 & -0.56 & -0.50 \\
\hline Baetidae \% & 0.25 & -0.18 & -0.45 & 0.54 & -0.30 & -0.38 & 0.27 & -0.20 & 0.24 & -0.21 & 0.64 & 0.36 \\
\hline pGC_abund & 0.35 & 0.14 & -0.18 & -0.17 & -0.02 & 0.38 & 0.63 & -0.58 & 0.07 & -0.22 & 0.46 & 0.70 \\
\hline SC_abund & -0.01 & 0.21 & 0.05 & -0.25 & -0.40 & -0.37 & -0.43 & -0.03 & 0.18 & -0.12 & -0.14 & -0.14 \\
\hline ODIPNIR & -0.26 & -0.13 & -0.08 & -0.28 & -0.00 & -0.42 & -0.40 & -0.10 & 0.47 & -0.38 & -0.12 & -0.37 \\
\hline pSC_abund & 0.02 & 0.27 & 0.02 & -0.22 & -0.40 & -0.35 & -0.38 & -0.09 & 0.20 & -0.16 & -0.08 & -0.12 \\
\hline
\end{tabular}


Table 16. Correlations between macroinvertebrate metrics and index and selected environmental factors for sites not affected by wastewater-treatment plants.-Continued

[Macroinvertebrate metrics are sorted by absolute value of correlation with percent forest; red font denotes absolute value of rho is greater than or equal to 0.50 ; metric abbreviations are listed in table 15 ; number of sites equals 14]

\begin{tabular}{|c|c|c|c|c|c|c|c|c|c|c|c|c|c|c|}
\hline & $\begin{array}{c}\text { Bed } \\
\text { substrate }\end{array}$ & $\begin{array}{l}\text { Embedded- } \\
\text { ness }\end{array}$ & $\begin{array}{l}\text { Substrate } \\
\text { turbidity }\end{array}$ & $\begin{array}{c}\text { Open } \\
\text { canopy } \\
\text { angle }\end{array}$ & $\begin{array}{c}\text { Combined } \\
\text { canopy } \\
\text { closure }\end{array}$ & $\begin{array}{c}\text { Bank } \\
\text { height }\end{array}$ & $\begin{array}{c}\text { Bank } \\
\text { angle }\end{array}$ & $\begin{array}{c}\text { Percent } \\
\text { forest }\end{array}$ & $\begin{array}{l}\text { Percent } \\
\text { agricul- } \\
\text { ture }\end{array}$ & $\begin{array}{c}\text { Percent } \\
\text { urban }\end{array}$ & $\begin{array}{c}\text { Poultry } \\
\text { house } \\
\text { density }\end{array}$ & $\begin{array}{l}\text { Total } \\
\text { unpaved } \\
\text { road } \\
\text { density }\end{array}$ & $\begin{array}{l}\text { Total } \\
\text { paved } \\
\text { road } \\
\text { density }\end{array}$ & $\begin{array}{c}\text { Total } \\
\text { road } \\
\text { density }\end{array}$ \\
\hline PR_rich & 0.39 & -0.49 & -0.05 & 0.18 & -0.52 & 0.35 & 0.44 & 0.91 & -0.20 & -0.85 & 0.12 & 0.24 & -0.80 & -0.83 \\
\hline Macroinvertebrate index & 0.39 & -0.53 & 0.03 & -0.45 & 0.32 & 0.44 & -0.06 & 0.86 & -0.15 & -0.81 & 0.19 & 0.26 & -0.71 & -0.77 \\
\hline PLECOR & 0.59 & -0.36 & -0.09 & 0.34 & -0.58 & 0.09 & 0.53 & 0.82 & -0.10 & -0.81 & 0.09 & 0.29 & -0.84 & -0.78 \\
\hline Margalef diversity & 0.31 & -0.60 & -0.02 & -0.11 & -0.26 & 0.39 & 0.47 & 0.82 & -0.11 & -0.80 & 0.20 & 0.20 & -0.68 & -0.75 \\
\hline SC_rich & 0.28 & -0.51 & -0.04 & -0.19 & 0.02 & 0.44 & 0.33 & 0.80 & 0.09 & -0.82 & 0.25 & 0.47 & -0.68 & -0.64 \\
\hline pPR_abund & 0.22 & -0.53 & -0.13 & 0.14 & -0.47 & 0.31 & 0.38 & 0.80 & -0.16 & -0.75 & 0.18 & 0.13 & -0.64 & -0.75 \\
\hline PR_abund & 0.21 & -0.52 & -0.11 & 0.09 & -0.43 & 0.36 & 0.37 & 0.79 & -0.18 & -0.74 & 0.13 & 0.14 & -0.62 & -0.74 \\
\hline $\mathrm{RICH}$ & 0.26 & -0.53 & 0.05 & -0.18 & -0.20 & 0.48 & 0.46 & 0.77 & -0.20 & -0.74 & 0.09 & 0.16 & -0.60 & -0.67 \\
\hline PLECORp & 0.54 & -0.35 & -0.19 & 0.42 & -0.63 & 0.00 & 0.49 & 0.77 & 0.04 & -0.80 & 0.11 & 0.30 & -0.81 & -0.78 \\
\hline pPR_rich & 0.26 & -0.33 & -0.22 & 0.33 & -0.51 & 0.25 & 0.32 & 0.73 & -0.07 & -0.72 & 0.05 & 0.23 & -0.68 & -0.68 \\
\hline EPTR & 0.70 & -0.57 & -0.14 & 0.13 & -0.49 & 0.13 & 0.68 & 0.72 & -0.06 & -0.75 & 0.01 & 0.16 & -0.70 & -0.71 \\
\hline PLECOp & 0.53 & -0.26 & -0.09 & 0.45 & -0.65 & -0.01 & 0.58 & 0.72 & 0.08 & -0.72 & 0.14 & 0.35 & -0.77 & -0.72 \\
\hline bu_richp & -0.25 & 0.45 & 0.28 & -0.14 & 0.28 & -0.05 & -0.04 & -0.70 & -0.18 & 0.70 & -0.50 & -0.35 & 0.63 & 0.68 \\
\hline Modtol_rich & 0.04 & -0.33 & 0.32 & -0.38 & 0.06 & 0.64 & 0.12 & 0.66 & -0.29 & -0.53 & 0.19 & 0.24 & -0.41 & -0.44 \\
\hline Dom4 & -0.58 & 0.69 & 0.18 & -0.06 & 0.53 & 0.04 & -0.47 & -0.66 & -0.13 & 0.73 & -0.33 & -0.16 & 0.67 & 0.83 \\
\hline Dom3 & -0.65 & 0.71 & 0.21 & 0.02 & 0.45 & -0.07 & -0.62 & -0.63 & -0.06 & 0.71 & -0.19 & -0.02 & 0.63 & 0.76 \\
\hline Dom5 & -0.55 & 0.71 & 0.26 & -0.07 & 0.51 & 0.08 & -0.50 & -0.59 & -0.23 & 0.68 & -0.36 & -0.12 & 0.61 & 0.78 \\
\hline Dom2 & -0.70 & 0.73 & 0.35 & -0.05 & 0.49 & 0.11 & -0.50 & -0.57 & -0.08 & 0.69 & -0.19 & 0.04 & 0.63 & 0.78 \\
\hline cb_abundp & 0.16 & -0.46 & -0.01 & -0.06 & 0.03 & 0.29 & 0.20 & 0.54 & -0.04 & -0.46 & 0.37 & 0.22 & -0.39 & -0.41 \\
\hline Baetidae \% & -0.01 & 0.06 & -0.14 & 0.38 & -0.25 & -0.29 & 0.25 & -0.52 & -0.03 & 0.40 & -0.45 & -0.67 & 0.38 & 0.30 \\
\hline pGC_abund & -0.27 & 0.36 & 0.05 & 0.11 & 0.34 & -0.43 & -0.58 & -0.50 & 0.23 & 0.40 & -0.09 & 0.13 & 0.32 & 0.42 \\
\hline SC_abund & 0.57 & -0.13 & 0.14 & -0.17 & -0.06 & 0.08 & 0.49 & 0.48 & 0.25 & -0.52 & 0.34 & 0.50 & -0.64 & -0.51 \\
\hline ODIPNIR & 0.07 & -0.22 & 0.31 & -0.05 & -0.18 & 0.35 & 0.29 & 0.48 & -0.16 & -0.51 & -0.13 & 0.09 & -0.42 & -0.49 \\
\hline pSC_abund & 0.55 & -0.12 & 0.08 & -0.19 & -0.02 & 0.06 & 0.46 & 0.45 & 0.29 & -0.49 & 0.36 & 0.49 & -0.60 & -0.48 \\
\hline
\end{tabular}


Table 17. Correlations between macroinvertebrate metrics and index and environmental factors at agriculture gradient sites in the Illinois River Basin study area.

[Macroinvertebrate metrics are sorted by absolute value of correlation with percent agriculture; red font denotes absolute value of rho is greater than or equal to 0.60 ; metric abbreviations are listed in table 15 ; number of sites equals 10]

\begin{tabular}{|c|c|c|c|c|c|c|c|c|c|c|c|c|}
\hline & $\begin{array}{c}\text { Nitrite } \\
\text { plus } \\
\text { nitrate }\end{array}$ & $\begin{array}{c}\text { Total } \\
\text { phospho- } \\
\text { rus }\end{array}$ & $\begin{array}{c}\text { Tempera- } \\
\text { ture }\end{array}$ & $\begin{array}{c}\text { Specific } \\
\text { conduc- } \\
\text { tance }\end{array}$ & $\begin{array}{l}\text { Dissolved } \\
\text { oxygen }\end{array}$ & $\mathrm{pH}$ & Streamflow & $\begin{array}{l}\text { Bankfull } \\
\text { width }\end{array}$ & $\begin{array}{c}\text { Drainage } \\
\text { area }\end{array}$ & $\begin{array}{c}\text { Bankfull } \\
\text { width/ } \\
\text { drainage } \\
\text { area }\end{array}$ & Depth & Velocity \\
\hline PR_rich & -0.68 & -0.47 & 0.34 & -0.29 & -0.25 & -0.41 & -0.74 & 0.61 & -0.37 & 0.65 & -0.50 & -0.47 \\
\hline Macroinvertebrate index & -0.66 & -0.49 & 0.31 & -0.15 & -0.24 & -0.50 & -0.84 & 0.60 & -0.44 & 0.70 & -0.68 & -0.64 \\
\hline $\mathrm{RICH}$ & -0.74 & -0.38 & 0.16 & -0.16 & -0.25 & -0.51 & -0.83 & 0.25 & -0.12 & 0.32 & -0.53 & -0.74 \\
\hline Margalef diversity & -0.67 & -0.37 & 0.09 & -0.04 & -0.18 & -0.56 & -0.81 & 0.27 & -0.13 & 0.31 & -0.56 & -0.77 \\
\hline PR_abund & -0.77 & -0.33 & 0.32 & -0.32 & 0.10 & -0.22 & -0.71 & 0.67 & -0.16 & 0.55 & -0.64 & -0.71 \\
\hline pPR_abund & -0.71 & -0.31 & 0.24 & -0.22 & 0.16 & -0.27 & -0.70 & 0.66 & -0.15 & 0.52 & -0.66 & -0.76 \\
\hline Modtol_rich & -0.72 & -0.14 & 0.33 & -0.22 & -0.21 & -0.46 & -0.74 & 0.06 & -0.14 & 0.14 & -0.58 & -0.66 \\
\hline PLECOR & -0.25 & -0.47 & 0.08 & 0.02 & -0.33 & -0.50 & -0.51 & 0.45 & -0.51 & 0.59 & -0.29 & -0.19 \\
\hline EPTR & -0.23 & -0.79 & -0.23 & -0.01 & -0.16 & -0.46 & -0.59 & 0.54 & -0.31 & 0.65 & -0.41 & -0.35 \\
\hline pGC_abund & 0.54 & 0.20 & -0.09 & -0.22 & 0.20 & 0.76 & 0.72 & -0.44 & 0.08 & -0.33 & 0.52 & 0.71 \\
\hline Dom4 & 0.53 & 0.41 & 0.01 & -0.12 & 0.05 & 0.58 & 0.67 & -0.60 & 0.01 & -0.45 & 0.52 & 0.67 \\
\hline ODIPNIR & -0.80 & -0.15 & 0.14 & -0.42 & -0.59 & -0.41 & -0.76 & -0.02 & 0.23 & 0.05 & -0.07 & -0.64 \\
\hline $\mathrm{SC}$ _rich & -0.29 & -0.25 & -0.16 & -0.14 & -0.07 & -0.15 & -0.35 & -0.22 & -0.06 & -0.08 & -0.09 & -0.35 \\
\hline Dom3 & 0.43 & 0.43 & 0.25 & -0.19 & 0.33 & 0.71 & 0.65 & -0.37 & -0.15 & -0.28 & 0.19 & 0.59 \\
\hline pPR_rich & -0.43 & -0.19 & 0.45 & -0.36 & -0.30 & -0.03 & -0.32 & 0.54 & -0.38 & 0.58 & -0.03 & -0.02 \\
\hline Dom2 & 0.47 & 0.32 & 0.14 & -0.13 & 0.42 & 0.62 & 0.58 & -0.39 & -0.21 & -0.27 & 0.02 & 0.49 \\
\hline PLECORp & -0.14 & -0.28 & 0.06 & 0.18 & -0.33 & -0.40 & -0.36 & 0.40 & -0.42 & 0.50 & -0.09 & -0.17 \\
\hline Dom5 & 0.38 & 0.28 & 0.15 & -0.27 & -0.02 & 0.54 & 0.52 & -0.52 & -0.15 & -0.30 & 0.36 & 0.64 \\
\hline Baetidae \% & 0.24 & -0.03 & -0.35 & 0.39 & -0.39 & -0.26 & 0.15 & 0.01 & 0.41 & -0.09 & 0.54 & 0.20 \\
\hline PLECOp & 0.04 & -0.40 & -0.10 & 0.19 & -0.03 & -0.36 & -0.35 & 0.58 & -0.56 & 0.66 & -0.37 & -0.23 \\
\hline bu_richp & 0.17 & -0.13 & 0.08 & -0.27 & -0.21 & 0.22 & 0.24 & -0.22 & 0.11 & -0.08 & 0.18 & 0.53 \\
\hline SC_abund & -0.15 & 0.05 & -0.09 & 0.21 & -0.84 & -0.83 & -0.43 & -0.27 & 0.01 & -0.12 & 0.18 & -0.15 \\
\hline pSC_abund & -0.10 & 0.14 & -0.15 & 0.27 & -0.81 & -0.81 & -0.36 & -0.33 & 0.09 & -0.22 & 0.28 & -0.15 \\
\hline cn_abundp & -0.10 & 0.37 & 0.50 & -0.12 & -0.12 & 0.29 & 0.16 & -0.15 & -0.32 & -0.04 & 0.22 & 0.22 \\
\hline
\end{tabular}


Table 17. Correlations between macroinvertebrate metrics and index and environmental factors at agriculture gradient sites in the Illinois River Basin study area.-Continued

[Macroinvertebrate metrics are sorted by absolute value of correlation with percent agriculture; red font denotes absolute value of rho is greater than or equal to 0.60 ; metric abbreviations are listed in table 15 ; number of sites equals 10$]$

\begin{tabular}{|c|c|c|c|c|c|c|c|c|c|c|c|c|c|c|}
\hline & $\begin{array}{c}\text { Bed } \\
\text { substrate }\end{array}$ & $\begin{array}{l}\text { Embed- } \\
\text { dedness }\end{array}$ & $\begin{array}{l}\text { Substrate } \\
\text { turbidity }\end{array}$ & $\begin{array}{c}\text { Open } \\
\text { canopy } \\
\text { angle }\end{array}$ & $\begin{array}{c}\text { Combined } \\
\text { canopy } \\
\text { closure }\end{array}$ & $\begin{array}{c}\text { Bank } \\
\text { height }\end{array}$ & $\begin{array}{l}\text { Bank } \\
\text { angle }\end{array}$ & $\begin{array}{c}\text { Percent } \\
\text { forest }\end{array}$ & $\begin{array}{l}\text { Percent } \\
\text { agricul- } \\
\text { ture }\end{array}$ & $\begin{array}{c}\text { Percent } \\
\text { urban }\end{array}$ & $\begin{array}{l}\text { Poultry } \\
\text { house } \\
\text { density }\end{array}$ & $\begin{array}{l}\text { Total } \\
\text { unpaved } \\
\text { road } \\
\text { density }\end{array}$ & $\begin{array}{c}\text { Total } \\
\text { paved } \\
\text { road } \\
\text { density }\end{array}$ & $\begin{array}{c}\text { Total } \\
\text { road } \\
\text { density }\end{array}$ \\
\hline PR_rich & 0.67 & -0.28 & 0.09 & 0.27 & -0.47 & 0.22 & 0.09 & 0.93 & -0.88 & -0.90 & -0.27 & -0.26 & -0.88 & -0.95 \\
\hline Macroinvertebrate index & 0.65 & -0.24 & 0.26 & 0.09 & -0.49 & 0.21 & 0.21 & 0.84 & -0.83 & -0.82 & -0.32 & -0.24 & -0.76 & -0.87 \\
\hline $\mathrm{RICH}$ & 0.51 & -0.39 & 0.28 & -0.30 & -0.10 & 0.46 & 0.09 & 0.81 & -0.80 & -0.78 & -0.30 & -0.29 & -0.57 & -0.71 \\
\hline Margalef diversity & 0.53 & -0.39 & 0.22 & -0.27 & -0.13 & 0.43 & 0.18 & 0.81 & -0.79 & -0.77 & -0.22 & -0.32 & -0.56 & -0.71 \\
\hline PR_abund & 0.43 & -0.49 & -0.02 & 0.07 & -0.37 & 0.31 & -0.02 & 0.77 & -0.78 & -0.76 & -0.13 & -0.41 & -0.56 & -0.83 \\
\hline pPR_abund & 0.42 & -0.48 & -0.03 & 0.04 & -0.36 & 0.32 & 0.06 & 0.75 & -0.76 & -0.72 & -0.07 & -0.42 & -0.53 & -0.79 \\
\hline Modtol_rich & 0.17 & -0.14 & 0.42 & -0.60 & 0.22 & 0.60 & -0.11 & 0.62 & -0.71 & -0.49 & -0.02 & 0.04 & -0.36 & -0.41 \\
\hline PLECOR & 0.73 & 0.00 & 0.07 & 0.48 & -0.53 & 0.01 & 0.35 & 0.79 & -0.68 & -0.77 & -0.28 & -0.12 & -0.91 & -0.78 \\
\hline EPTR & 0.93 & -0.34 & 0.20 & 0.46 & -0.65 & -0.01 & 0.59 & 0.73 & -0.63 & -0.74 & -0.56 & -0.38 & -0.75 & -0.77 \\
\hline pGC_abund & -0.53 & 0.35 & -0.03 & 0.08 & 0.35 & -0.21 & -0.49 & -0.61 & 0.62 & 0.53 & -0.05 & 0.47 & 0.49 & 0.67 \\
\hline Dom4 & -0.66 & 0.59 & 0.05 & -0.12 & 0.52 & -0.09 & -0.50 & -0.61 & 0.60 & 0.59 & 0.14 & 0.66 & 0.48 & 0.76 \\
\hline ODIPNIR & 0.32 & -0.27 & 0.44 & -0.40 & 0.06 & 0.61 & -0.01 & 0.55 & -0.55 & -0.57 & -0.46 & -0.20 & -0.34 & -0.48 \\
\hline SC_rich & 0.25 & -0.14 & 0.16 & -0.25 & 0.28 & 0.49 & -0.16 & 0.65 & -0.55 & -0.68 & -0.28 & 0.03 & -0.44 & -0.35 \\
\hline Dom3 & -0.79 & 0.56 & 0.01 & -0.15 & 0.48 & -0.12 & -0.67 & -0.61 & 0.53 & 0.64 & 0.33 & 0.71 & 0.53 & 0.73 \\
\hline pPR_rich & 0.42 & -0.04 & -0.22 & 0.65 & -0.54 & -0.07 & -0.18 & 0.65 & -0.53 & -0.75 & -0.25 & -0.14 & -0.79 & -0.79 \\
\hline Dom2 & -0.75 & 0.58 & 0.15 & -0.27 & 0.54 & -0.03 & -0.57 & -0.56 & 0.45 & 0.64 & 0.33 & 0.77 & 0.53 & 0.77 \\
\hline PLECORp & 0.61 & -0.01 & -0.15 & 0.56 & -0.60 & -0.15 & 0.31 & 0.62 & -0.45 & -0.72 & -0.28 & -0.24 & -0.77 & -0.73 \\
\hline Dom5 & -0.58 & 0.64 & 0.21 & -0.13 & 0.49 & -0.01 & -0.57 & -0.44 & 0.41 & 0.45 & 0.07 & 0.77 & 0.31 & 0.64 \\
\hline Baetidae \% & 0.35 & -0.28 & -0.30 & 0.39 & -0.43 & -0.48 & 0.58 & -0.28 & 0.39 & 0.15 & -0.24 & -0.59 & 0.10 & -0.04 \\
\hline PLECOp & 0.58 & 0.13 & 0.06 & 0.61 & -0.69 & -0.14 & 0.54 & 0.48 & -0.39 & -0.50 & -0.20 & -0.09 & -0.64 & -0.57 \\
\hline bu_richp & -0.11 & 0.13 & 0.35 & -0.09 & 0.15 & -0.18 & -0.09 & -0.46 & 0.34 & 0.53 & -0.16 & 0.27 & 0.33 & 0.46 \\
\hline SC_abund & 0.32 & 0.33 & 0.43 & -0.20 & 0.05 & 0.28 & 0.51 & 0.24 & -0.22 & -0.13 & -0.07 & 0.12 & -0.35 & -0.12 \\
\hline pSC_abund & 0.26 & 0.31 & 0.32 & -0.20 & 0.09 & 0.28 & 0.50 & 0.20 & -0.16 & -0.12 & -0.02 & 0.07 & -0.30 & -0.09 \\
\hline cn_abundp & -0.30 & 0.30 & -0.34 & 0.10 & 0.15 & -0.04 & -0.70 & 0.20 & -0.09 & -0.32 & 0.12 & 0.29 & -0.27 & -0.16 \\
\hline
\end{tabular}


[Macroinvertebrate metrics are sorted by absolute value of correlation with percent urban; red font denotes absolute value of rho is greater than or equal to 0.80 ; metric abbreviations are listed in table 15 ; number of sites equals 6]

\begin{tabular}{|c|c|c|c|c|c|c|c|c|c|c|c|c|}
\hline & $\begin{array}{c}\text { Nitrite } \\
\text { plus nitrate }\end{array}$ & $\begin{array}{c}\text { Total } \\
\text { phosphorus }\end{array}$ & $\begin{array}{l}\text { Tempera- } \\
\text { ture }\end{array}$ & $\begin{array}{c}\text { Specific } \\
\text { conduc- } \\
\text { tance }\end{array}$ & $\begin{array}{l}\text { Dissolved } \\
\text { oxygen }\end{array}$ & $\mathrm{pH}$ & Streamflow & $\begin{array}{c}\text { Bankfull } \\
\text { width }\end{array}$ & $\begin{array}{l}\text { Drainage } \\
\text { area }\end{array}$ & $\begin{array}{l}\text { Bankfull } \\
\text { width/ } \\
\text { drainage } \\
\text { area }\end{array}$ & Depth & Velocity \\
\hline Dom3 & 0.71 & 0.49 & -0.31 & 0.89 & -0.09 & -0.03 & 0.77 & -0.66 & -0.09 & 0.03 & 0.71 & 0.66 \\
\hline Macroinvertebrate index & -0.49 & -0.71 & 0.54 & -0.66 & 0.09 & 0.14 & -0.77 & 0.71 & 0.09 & 0.03 & -0.83 & -0.71 \\
\hline SC_rich & -0.49 & -0.71 & 0.54 & -0.66 & 0.09 & 0.14 & -0.77 & 0.71 & 0.09 & 0.03 & -0.83 & -0.71 \\
\hline PLECORp & -0.39 & -0.70 & 0.33 & -0.76 & 0.27 & -0.15 & -0.64 & 0.52 & 0.15 & -0.21 & -0.70 & -0.52 \\
\hline SC_abund & -0.75 & -0.38 & 0.64 & -0.84 & -0.35 & 0.32 & -0.70 & 0.38 & -0.29 & 0.38 & -0.78 & -0.38 \\
\hline Dom4 & 0.89 & 0.43 & -0.43 & 0.94 & 0.20 & -0.20 & 0.83 & -0.60 & -0.03 & -0.14 & 0.77 & 0.60 \\
\hline Dom5 & 0.89 & 0.43 & -0.43 & 0.94 & 0.20 & -0.20 & 0.83 & -0.60 & -0.03 & -0.14 & 0.77 & 0.60 \\
\hline PLECOp & -0.52 & -0.64 & 0.15 & -0.82 & 0.33 & -0.21 & -0.70 & 0.64 & 0.33 & -0.33 & -0.64 & -0.64 \\
\hline Dom2 & 0.77 & 0.37 & -0.20 & 1.00 & 0.03 & 0.09 & 0.66 & -0.37 & -0.09 & 0.09 & 0.60 & 0.37 \\
\hline PR_rich & -0.26 & -0.83 & 0.37 & -0.54 & 0.31 & -0.09 & -0.66 & 0.66 & 0.31 & -0.26 & -0.71 & -0.66 \\
\hline pSC_abund & -0.71 & -0.26 & 0.66 & -0.77 & -0.43 & 0.37 & -0.60 & 0.26 & -0.43 & 0.49 & -0.71 & -0.26 \\
\hline ODIPNIR & -0.20 & -0.70 & 0.12 & -0.70 & 0.46 & -0.41 & -0.46 & 0.35 & 0.29 & -0.46 & -0.52 & -0.35 \\
\hline Margalef diversity & -0.14 & -0.77 & 0.14 & -0.60 & 0.49 & -0.37 & -0.49 & 0.43 & 0.37 & -0.49 & -0.54 & -0.43 \\
\hline pPR_rich & -0.03 & -0.66 & 0.31 & -0.37 & 0.43 & -0.14 & -0.43 & 0.49 & 0.09 & -0.20 & -0.54 & -0.49 \\
\hline $\mathrm{RICH}$ & -0.14 & -0.77 & 0.14 & -0.60 & 0.49 & -0.37 & -0.49 & 0.43 & 0.37 & -0.49 & -0.54 & -0.43 \\
\hline PLECOR & -0.18 & -0.74 & 0.09 & -0.68 & 0.44 & -0.44 & -0.44 & 0.29 & 0.38 & -0.53 & -0.50 & -0.29 \\
\hline Baetidae \% & 0.77 & 0.37 & -0.83 & 0.66 & 0.66 & -0.60 & 0.71 & -0.37 & 0.31 & -0.60 & 0.83 & 0.37 \\
\hline pPR_abund & -0.26 & -0.71 & -0.03 & -0.66 & 0.54 & -0.43 & -0.54 & 0.54 & 0.54 & -0.60 & -0.49 & -0.54 \\
\hline PR_abund & -0.26 & -0.71 & -0.03 & -0.66 & 0.54 & -0.43 & -0.54 & 0.54 & 0.54 & -0.60 & -0.49 & -0.54 \\
\hline Modtol_rich & -0.35 & -0.88 & 0.71 & -0.35 & -0.09 & 0.35 & -0.79 & 0.79 & 0.26 & 0.09 & -0.88 & -0.79 \\
\hline cn_abundp & -0.13 & -0.65 & 0.65 & -0.39 & -0.13 & 0.13 & -0.39 & 0.13 & -0.13 & 0.13 & -0.65 & -0.13 \\
\hline EPTR & -0.31 & -0.60 & -0.14 & -0.77 & 0.43 & -0.54 & -0.43 & 0.26 & 0.54 & -0.66 & -0.37 & -0.26 \\
\hline pGC_abund & 0.20 & 0.14 & -0.03 & 0.20 & -0.37 & -0.03 & 0.37 & -0.66 & -0.03 & 0.03 & 0.26 & 0.66 \\
\hline bu_richp & 0.88 & 0.52 & -0.52 & 0.58 & 0.58 & -0.52 & 0.88 & -0.70 & -0.39 & -0.21 & 0.76 & 0.70 \\
\hline
\end{tabular}


Table 18. Correlations between macroinvertebrate metrics and index and selected environmental factors at urban gradient sites in the Illinois River Basin study area.Continued

[Macroinvertebrate metrics are sorted by absolute value of correlation with percent urban; red font denotes absolute value of rho is greater than or equal to 0.80 ; metric abbreviations are listed in table 15 ; number of sites equals 6 ]

\begin{tabular}{|c|c|c|c|c|c|c|c|c|c|c|c|c|c|c|}
\hline & $\begin{array}{c}\text { Bed } \\
\text { substrate }\end{array}$ & $\begin{array}{l}\text { Embedded- } \\
\text { ness }\end{array}$ & $\begin{array}{l}\text { Substrate } \\
\text { turbidity }\end{array}$ & $\begin{array}{c}\text { Open } \\
\text { canopy } \\
\text { angle }\end{array}$ & $\begin{array}{c}\text { Combined } \\
\text { canopy } \\
\text { closure }\end{array}$ & $\begin{array}{c}\text { Bank } \\
\text { height }\end{array}$ & $\begin{array}{l}\text { Bank } \\
\text { angle }\end{array}$ & $\begin{array}{c}\text { Percent } \\
\text { forest }\end{array}$ & $\begin{array}{c}\text { Percent } \\
\text { agriculture }\end{array}$ & $\begin{array}{c}\text { Percent } \\
\text { urban }\end{array}$ & $\begin{array}{c}\text { Poultry } \\
\text { house } \\
\text { density }\end{array}$ & $\begin{array}{c}\text { Total } \\
\text { unpaved } \\
\text { road } \\
\text { density }\end{array}$ & $\begin{array}{c}\text { Total } \\
\text { paved } \\
\text { road } \\
\text { density }\end{array}$ & $\begin{array}{c}\text { Total } \\
\text { road } \\
\text { density }\end{array}$ \\
\hline Dom3 & -0.83 & 0.94 & 0.20 & 0.20 & 0.49 & -0.26 & -0.60 & -0.89 & -0.20 & 0.94 & -0.66 & -0.71 & 0.83 & 0.89 \\
\hline Macroinvertebrate index & 0.54 & -0.77 & 0.20 & -0.14 & -0.54 & 0.43 & 0.60 & 1.00 & -0.20 & -0.94 & 0.37 & 0.66 & -0.71 & -0.66 \\
\hline SC_rich & 0.54 & -0.77 & 0.20 & -0.14 & -0.54 & 0.43 & 0.60 & 1.00 & -0.20 & -0.94 & 0.37 & 0.66 & -0.71 & -0.66 \\
\hline PLECORp & 0.52 & -0.76 & 0.09 & -0.03 & -0.64 & 0.27 & 0.70 & 0.94 & -0.09 & -0.94 & 0.33 & 0.64 & -0.82 & -0.76 \\
\hline SC_abund & 0.81 & -0.90 & -0.20 & -0.49 & -0.23 & -0.17 & 0.14 & 0.75 & 0.20 & -0.90 & 0.81 & 0.99 & -0.93 & -0.84 \\
\hline Dom4 & -0.94 & 1.00 & 0.26 & 0.26 & 0.43 & 0.03 & -0.31 & -0.77 & -0.26 & 0.89 & -0.83 & -0.83 & 0.89 & 0.94 \\
\hline Dom5 & -0.94 & 1.00 & 0.26 & 0.26 & 0.43 & 0.03 & -0.31 & -0.77 & -0.26 & 0.89 & -0.83 & -0.83 & 0.89 & 0.94 \\
\hline PLECOp & 0.64 & -0.82 & -0.03 & 0.09 & -0.70 & 0.33 & 0.76 & 0.88 & 0.03 & -0.88 & 0.39 & 0.52 & -0.76 & -0.82 \\
\hline Dom2 & -0.89 & 0.94 & 0.37 & 0.14 & 0.49 & 0.20 & -0.37 & -0.66 & -0.37 & 0.83 & -0.77 & -0.77 & 0.94 & 1.00 \\
\hline PR_rich & 0.31 & -0.60 & 0.37 & 0.14 & -0.71 & 0.49 & 0.71 & 0.94 & -0.37 & -0.83 & 0.09 & 0.43 & -0.60 & -0.54 \\
\hline pSC_abund & 0.77 & -0.83 & -0.26 & -0.60 & -0.09 & -0.26 & 0.03 & 0.66 & 0.26 & -0.83 & 0.83 & 1.00 & -0.89 & -0.77 \\
\hline ODIPNIR & 0.35 & -0.61 & 0.12 & 0.17 & -0.72 & 0.20 & 0.75 & 0.81 & -0.12 & -0.81 & 0.14 & 0.46 & -0.75 & -0.70 \\
\hline Margalef diversity & 0.26 & -0.54 & 0.26 & 0.26 & -0.77 & 0.31 & 0.77 & 0.83 & -0.26 & -0.77 & 0.03 & 0.37 & -0.66 & -0.60 \\
\hline pPR_rich & 0.14 & -0.43 & 0.31 & -0.03 & -0.49 & 0.60 & 0.77 & 0.89 & -0.31 & -0.77 & -0.03 & 0.37 & -0.49 & -0.37 \\
\hline RICH & 0.26 & -0.54 & 0.26 & 0.26 & -0.77 & 0.31 & 0.77 & 0.83 & -0.26 & -0.77 & 0.03 & 0.37 & -0.66 & -0.60 \\
\hline PLECOR & 0.29 & -0.56 & 0.18 & 0.29 & -0.79 & 0.09 & 0.68 & 0.74 & -0.18 & -0.74 & 0.09 & 0.41 & -0.74 & -0.68 \\
\hline Baetidae \% & -0.71 & 0.77 & 0.03 & 0.49 & 0.14 & 0.31 & 0.20 & -0.60 & -0.03 & 0.71 & -0.77 & -0.94 & 0.77 & 0.66 \\
\hline pPR_abund & 0.37 & -0.60 & 0.14 & 0.37 & -0.83 & 0.37 & 0.83 & 0.77 & -0.14 & -0.71 & 0.09 & 0.26 & -0.60 & -0.66 \\
\hline PR_abund & 0.37 & -0.60 & 0.14 & 0.37 & -0.83 & 0.37 & 0.83 & 0.77 & -0.14 & -0.71 & 0.09 & 0.26 & -0.60 & -0.66 \\
\hline Modtol_rich & 0.26 & -0.53 & 0.62 & 0.09 & -0.62 & 0.44 & 0.35 & 0.88 & -0.62 & -0.71 & 0.09 & 0.44 & -0.44 & -0.35 \\
\hline cn_abundp & 0.13 & -0.39 & 0.39 & -0.13 & -0.39 & -0.13 & 0.13 & 0.65 & -0.39 & -0.65 & 0.13 & 0.65 & -0.65 & -0.39 \\
\hline EPTR & 0.43 & -0.60 & -0.03 & 0.43 & -0.83 & -0.09 & 0.60 & 0.54 & 0.03 & -0.60 & 0.20 & 0.31 & -0.71 & -0.77 \\
\hline pGC_abund & -0.31 & 0.37 & 0.09 & 0.20 & 0.09 & -0.89 & -0.71 & -0.60 & -0.09 & 0.49 & -0.14 & -0.09 & 0.09 & 0.20 \\
\hline bu_richp & -0.70 & 0.70 & -0.15 & -0.15 & 0.52 & 0.21 & 0.21 & -0.39 & 0.15 & 0.39 & -0.58 & -0.46 & 0.46 & 0.58 \\
\hline
\end{tabular}


Table 19. Fish relative abundance and taxa richness for the sampling sites in the Illinois River Basin study area.

[Relative abundance in percent; $\mathrm{NC}$, not collected]

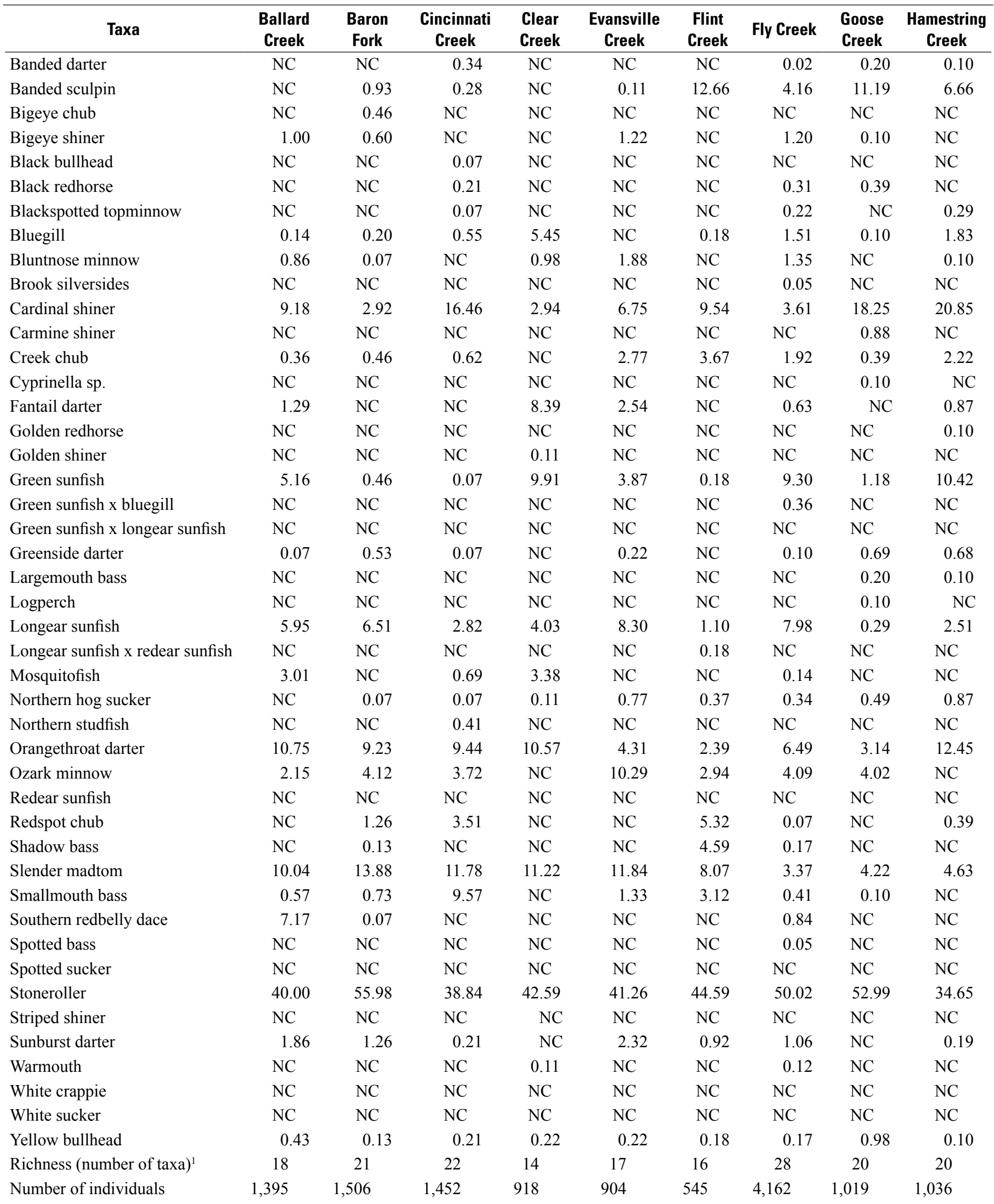


Table 19. Fish relative abundance and taxa richness for the sampling sites in the Illinois River Basin study area.-Continued

[Relative abundance in percent; $\mathrm{NC}$, not collected]

\begin{tabular}{|c|c|c|c|c|c|c|c|c|c|}
\hline Taxa & $\begin{array}{l}\text { Illinois } \\
\text { River }\end{array}$ & $\begin{array}{l}\text { Little } \\
\text { Osage } \\
\text { Creek } \\
\end{array}$ & $\begin{array}{l}\text { Moores } \\
\text { Creek }\end{array}$ & $\begin{array}{l}\text { Mud } \\
\text { Creek }\end{array}$ & $\begin{array}{c}\text { Osage } \\
\text { Creek-Cave } \\
\text { Springs }\end{array}$ & $\begin{array}{l}\text { Osage } \\
\text { Creek- } \\
\text { Rogers }\end{array}$ & $\begin{array}{l}\text { Spring } \\
\text { Creek }\end{array}$ & $\begin{array}{l}\text { Weddington } \\
\text { Creek }\end{array}$ & $\begin{array}{c}\text { Wildcat } \\
\text { Creek }\end{array}$ \\
\hline Banded darter & $\mathrm{NC}$ & $\mathrm{NC}$ & 1.58 & $\mathrm{NC}$ & 0.11 & 0.05 & $\mathrm{NC}$ & 0.10 & $\mathrm{NC}$ \\
\hline Banded sculpin & $\mathrm{NC}$ & 12.25 & 7.92 & $\mathrm{NC}$ & 6.49 & 8.29 & 0.67 & 5.82 & 0.61 \\
\hline Bigeye chub & $\mathrm{NC}$ & $\mathrm{NC}$ & $\mathrm{NC}$ & $\mathrm{NC}$ & $\mathrm{NC}$ & $\mathrm{NC}$ & $\mathrm{NC}$ & $\mathrm{NC}$ & $\mathrm{NC}$ \\
\hline Bigeye shiner & 3.31 & $\mathrm{NC}$ & 1.81 & 1.14 & $\mathrm{NC}$ & $\mathrm{NC}$ & $\mathrm{NC}$ & $\mathrm{NC}$ & $\mathrm{NC}$ \\
\hline Black bullhead & $\mathrm{NC}$ & $\mathrm{NC}$ & $\mathrm{NC}$ & $\mathrm{NC}$ & $\mathrm{NC}$ & $\mathrm{NC}$ & $\mathrm{NC}$ & $\mathrm{NC}$ & $\mathrm{NC}$ \\
\hline Black redhorse & 1.10 & 0.17 & 2.04 & $\mathrm{NC}$ & 0.34 & $\mathrm{NC}$ & $\mathrm{NC}$ & $\mathrm{NC}$ & $\mathrm{NC}$ \\
\hline Blackspotted topminnow & 0.76 & $\mathrm{NC}$ & 0.45 & 0.38 & $\mathrm{NC}$ & $\mathrm{NC}$ & $\mathrm{NC}$ & 0.10 & $\mathrm{NC}$ \\
\hline Bluegill & 0.42 & $\mathrm{NC}$ & 3.39 & 5.82 & 0.57 & 2.79 & 0.15 & 0.41 & $\mathrm{NC}$ \\
\hline Bluntnose minnow & 3.31 & $\mathrm{NC}$ & 8.37 & 3.81 & $\mathrm{NC}$ & $\mathrm{NC}$ & $\mathrm{NC}$ & $\mathrm{NC}$ & $\mathrm{NC}$ \\
\hline Brook silversides & $\mathrm{NC}$ & $\mathrm{NC}$ & $\mathrm{NC}$ & $\mathrm{NC}$ & $\mathrm{NC}$ & $\mathrm{NC}$ & $\mathrm{NC}$ & $\mathrm{NC}$ & $\mathrm{NC}$ \\
\hline Cardinal shiner & 5.85 & 9.06 & 17.65 & 0.54 & 8.31 & 0.96 & 7.76 & 13.28 & 14.90 \\
\hline Carmine shiner & $\mathrm{NC}$ & $\mathrm{NC}$ & $\mathrm{NC}$ & $\mathrm{NC}$ & $\mathrm{NC}$ & $\mathrm{NC}$ & $\mathrm{NC}$ & $\mathrm{NC}$ & $\mathrm{NC}$ \\
\hline Creek chub & $\mathrm{NC}$ & 5.37 & $\mathrm{NC}$ & 0.05 & 1.94 & 2.65 & 1.12 & 2.55 & 1.49 \\
\hline Cyprinella sp. & $\mathrm{NC}$ & $\mathrm{NC}$ & $\mathrm{NC}$ & $\mathrm{NC}$ & $\mathrm{NC}$ & $\mathrm{NC}$ & $\mathrm{NC}$ & $\mathrm{NC}$ & $\mathrm{NC}$ \\
\hline Fantail darter & 0.25 & 5.20 & $\mathrm{NC}$ & $\mathrm{NC}$ & $\mathrm{NC}$ & $\mathrm{NC}$ & $\mathrm{NC}$ & $\mathrm{NC}$ & $\mathrm{NC}$ \\
\hline Golden redhorse & $\mathrm{NC}$ & $\mathrm{NC}$ & $\mathrm{NC}$ & 0.05 & $\mathrm{NC}$ & $\mathrm{NC}$ & $\mathrm{NC}$ & $\mathrm{NC}$ & $\mathrm{NC}$ \\
\hline Golden shiner & $\mathrm{NC}$ & $\mathrm{NC}$ & $\mathrm{NC}$ & $\mathrm{NC}$ & $\mathrm{NC}$ & $\mathrm{NC}$ & $\mathrm{NC}$ & $\mathrm{NC}$ & $\mathrm{NC}$ \\
\hline Green sunfish & 12.03 & 8.39 & 11.76 & 4.08 & 2.16 & 10.12 & 0.82 & 0.61 & 1.05 \\
\hline Green sunfish $\mathrm{x}$ bluegill & $\mathrm{NC}$ & $\mathrm{NC}$ & $\mathrm{NC}$ & $\mathrm{NC}$ & $\mathrm{NC}$ & 0.72 & $\mathrm{NC}$ & $\mathrm{NC}$ & $\mathrm{NC}$ \\
\hline Green sunfish $\mathrm{x}$ longear sunfish & $\mathrm{NC}$ & 0.17 & $\mathrm{NC}$ & $\mathrm{NC}$ & $\mathrm{NC}$ & $\mathrm{NC}$ & $\mathrm{NC}$ & 0.10 & $\mathrm{NC}$ \\
\hline Greenside darter & 0.17 & 0.34 & 0.45 & $\mathrm{NC}$ & 0.23 & $\mathrm{NC}$ & $\mathrm{NC}$ & 0.72 & 0.09 \\
\hline Largemouth bass & $\mathrm{NC}$ & 0.17 & $\mathrm{NC}$ & 0.38 & 0.11 & $\mathrm{NC}$ & $\mathrm{NC}$ & $\mathrm{NC}$ & $\mathrm{NC}$ \\
\hline Logperch & $\mathrm{NC}$ & $\mathrm{NC}$ & 0.90 & $\mathrm{NC}$ & 0.23 & $\mathrm{NC}$ & $\mathrm{NC}$ & $\mathrm{NC}$ & $\mathrm{NC}$ \\
\hline Longear sunfish & 21.78 & $\mathrm{NC}$ & 16.29 & 6.97 & 0.68 & $\mathrm{NC}$ & 0.97 & 0.10 & 0.18 \\
\hline Longear sunfish $\mathrm{x}$ redear sunfish & $\mathrm{NC}$ & $\mathrm{NC}$ & $\mathrm{NC}$ & $\mathrm{NC}$ & $\mathrm{NC}$ & $\mathrm{NC}$ & $\mathrm{NC}$ & $\mathrm{NC}$ & $\mathrm{NC}$ \\
\hline Mosquitofish & $\mathrm{NC}$ & 0.84 & 2.49 & 2.50 & 0.23 & 0.29 & 0.07 & 0.72 & 0.18 \\
\hline Northern hog sucker & 0.59 & 1.17 & $\mathrm{NC}$ & 0.11 & 1.37 & $\mathrm{NC}$ & 0.07 & 0.82 & $\mathrm{NC}$ \\
\hline Northern studfish & $\mathrm{NC}$ & $\mathrm{NC}$ & $\mathrm{NC}$ & $\mathrm{NC}$ & $\mathrm{NC}$ & $\mathrm{NC}$ & $\mathrm{NC}$ & 0.10 & $\mathrm{NC}$ \\
\hline Orangethroat darter & 6.27 & 23.15 & 4.52 & 28.14 & 7.06 & 7.56 & 0.75 & 8.58 & 13.76 \\
\hline Ozark minnow & 6.53 & $\mathrm{NC}$ & 1.36 & $\mathrm{NC}$ & 0.11 & $\mathrm{NC}$ & $\mathrm{NC}$ & 3.88 & 1.93 \\
\hline Redear sunfish & $\mathrm{NC}$ & $\mathrm{NC}$ & $\mathrm{NC}$ & 0.05 & $\mathrm{NC}$ & $\mathrm{NC}$ & $\mathrm{NC}$ & $\mathrm{NC}$ & $\mathrm{NC}$ \\
\hline Redspot chub & 0.17 & 1.51 & $\mathrm{NC}$ & $\mathrm{NC}$ & $\mathrm{NC}$ & 0.05 & $\mathrm{NC}$ & 2.15 & 1.14 \\
\hline Shadow bass & 0.25 & $\mathrm{NC}$ & $\mathrm{NC}$ & $\mathrm{NC}$ & $\mathrm{NC}$ & 0.19 & $\mathrm{NC}$ & 0.10 & $\mathrm{NC}$ \\
\hline Slender madtom & 2.71 & 5.54 & 0.68 & 1.36 & 6.83 & 0.05 & $\mathrm{NC}$ & 15.53 & 12.80 \\
\hline Smallmouth bass & 0.42 & $\mathrm{NC}$ & $\mathrm{NC}$ & $\mathrm{NC}$ & 0.68 & $\mathrm{NC}$ & 0.67 & 3.17 & 2.10 \\
\hline Southern redbelly dace & $\mathrm{NC}$ & 1.85 & $\mathrm{NC}$ & $\mathrm{NC}$ & $\mathrm{NC}$ & 1.69 & 0.07 & $\mathrm{NC}$ & $\mathrm{NC}$ \\
\hline Spotted bass & 0.17 & $\mathrm{NC}$ & 1.36 & $\mathrm{NC}$ & $\mathrm{NC}$ & $\mathrm{NC}$ & $\mathrm{NC}$ & $\mathrm{NC}$ & $\mathrm{NC}$ \\
\hline Spotted sucker & $\mathrm{NC}$ & $\mathrm{NC}$ & 0.45 & $\mathrm{NC}$ & $\mathrm{NC}$ & $\mathrm{NC}$ & $\mathrm{NC}$ & $\mathrm{NC}$ & $\mathrm{NC}$ \\
\hline Stoneroller & 32.97 & 21.64 & 15.16 & 44.53 & 62.19 & 63.54 & 78.96 & 41.16 & 48.47 \\
\hline Striped shiner & $\mathrm{NC}$ & $\mathrm{NC}$ & $\mathrm{NC}$ & $\mathrm{NC}$ & $\mathrm{NC}$ & $\mathrm{NC}$ & $\mathrm{NC}$ & $\mathrm{NC}$ & 0.09 \\
\hline Sunburst darter & 0.42 & 2.18 & 0.23 & $\mathrm{NC}$ & 0.23 & 0.87 & 0.45 & $\mathrm{NC}$ & 1.23 \\
\hline Warmouth & 0.08 & $\mathrm{NC}$ & $\mathrm{NC}$ & $\mathrm{NC}$ & $\mathrm{NC}$ & 0.19 & $\mathrm{NC}$ & $\mathrm{NC}$ & $\mathrm{NC}$ \\
\hline White crappie & $\mathrm{NC}$ & $\mathrm{NC}$ & $\mathrm{NC}$ & 0.05 & $\mathrm{NC}$ & $\mathrm{NC}$ & $\mathrm{NC}$ & $\mathrm{NC}$ & $\mathrm{NC}$ \\
\hline White sucker & $\mathrm{NC}$ & 1.01 & $\mathrm{NC}$ & $\mathrm{NC}$ & $\mathrm{NC}$ & $\mathrm{NC}$ & $\mathrm{NC}$ & $\mathrm{NC}$ & $\mathrm{NC}$ \\
\hline Yellow bullhead & 0.42 & $\mathrm{NC}$ & 1.13 & $\mathrm{NC}$ & 0.11 & $\mathrm{NC}$ & 7.46 & $\mathrm{NC}$ & $\mathrm{NC}$ \\
\hline Richness (number of taxa) ${ }^{1}$ & 22 & 18 & 21 & 17 & 20 & 15 & 14 & 19 & 15 \\
\hline Number of individuals & 1,180 & 596 & 442 & 1,837 & 878 & 2,076 & 1,340 & 979 & 1,141 \\
\hline
\end{tabular}

${ }^{1}$ Does not include hybrids or unidentified Cyprinella. Stonerollers considered as one species (likely to be two species at many or all sites). 
Table 20. List of fish metrics.

[All metrics are for relative abundance unless otherwise noted. --, No reference; GSFYBHBGCC is green sunfish plus yellow bullhead plus bluegill plus channel catfish; PAHINP is algivorous/herbivorous, invertivorous, piscivorous; IBI, Ozark Highlands fish index of biotic integrity; NA is not applicable]

\begin{tabular}{|c|c|c|c|}
\hline Metric & Reference & $\begin{array}{l}\text { Used to } \\
\text { calculate } \\
\text { index }\end{array}$ & $\begin{array}{c}\text { Expected response } \\
\text { to environmental } \\
\text { degradation }\end{array}$ \\
\hline Tolerant & Dauwalter and others (2003) & No & Decreases \\
\hline Lithophilic spawners & Dauwalter and others (2003) & No & Decreases \\
\hline Lithophilic spawners minus stonerollers & Dauwalter and others (2003) & No & Decreases \\
\hline Smallmouth bass & -- & No & Decreases \\
\hline Invertivores & Dauwalter and others (2003) & No & Decreases \\
\hline Darters + madtoms + sculpins & Dauwalter and others (2003) & No & Decreases \\
\hline Yellow bullhead & -- & No & Increases \\
\hline GSFYBHBGCC & Dauwalter and others (2003) & Yes & Increases \\
\hline Top carnivores & Dauwalter and others (2003) & Yes & Decreases \\
\hline PAHINP & Dauwalter and others (2003) & Yes & Increases \\
\hline Darters + madtoms + sculpins (richness) & Dauwalter and others (2003) & Yes & Decreases \\
\hline Lithophilic spawners (richness) & Dauwalter and others (2003) & Yes & Decreases \\
\hline IBI score & Dauwalter and others (2003) & NA & Decreases \\
\hline
\end{tabular}


Table 21. Fish metric and index of biotic integrity values for sampling sites in the Illinois River Basin study area.

[Sites are sorted by IBI score; all metrics are relative abundance values (percent individuals in sample), unless otherwise noted. GSFYBHBGCC, green sunfish plus yellow bullhead plus bluegill plus channel catfish; PAHINP, percent algivorous/herbivorous, invertivorous, piscivorous; IBI, index of biotic integrity. See table 19 for additional information about metrics. Index values were rounded to nearest whole number.]

\begin{tabular}{|c|c|c|c|c|c|c|c|c|c|}
\hline Short site name & $\begin{array}{c}\text { Algivores } \\
\text { plus } \\
\text { detritivores }\end{array}$ & $\begin{array}{l}\text { Toler- } \\
\text { ant }\end{array}$ & $\begin{array}{l}\text { Lithophilic } \\
\text { spawners }\end{array}$ & $\begin{array}{l}\text { Stone- } \\
\text { rollers }\end{array}$ & $\begin{array}{c}\text { Lithophilic } \\
\text { spawners } \\
\text { minus } \\
\text { stonerollers }\end{array}$ & $\begin{array}{c}\text { Small- } \\
\text { mouth } \\
\text { bass }\end{array}$ & $\begin{array}{c}\text { Inverti- } \\
\text { vores }\end{array}$ & $\begin{array}{c}\text { Darters plus } \\
\text { madtom plus } \\
\text { sculpins }\end{array}$ & Centrarchidae \\
\hline Weddington Creek ${ }^{1}$ & 45.0 & 58.2 & 91.4 & 41.2 & 50.3 & 3.2 & 25.2 & 30.7 & 4.5 \\
\hline Wildcat Creek ${ }^{1}$ & 50.4 & 67.1 & 98.1 & 48.5 & 49.6 & 2.1 & 28.1 & 28.5 & 3.3 \\
\hline Evansville Creek $^{2}$ & 51.5 & 72.9 & 93.7 & 41.3 & 52.4 & 1.3 & 30.8 & 21.3 & 13.5 \\
\hline Ballard Creek ${ }^{1}$ & 49.3 & 68.8 & 90.3 & 40.0 & 50.3 & 0.6 & 31.0 & 24.0 & 11.8 \\
\hline Illinois River ${ }^{2}$ & 39.5 & 84.7 & 82.6 & 33.0 & 49.7 & 0.4 & 36.8 & 9.8 & 35.2 \\
\hline Osage Creek-Cave Springs ${ }^{3}$ & 62.3 & 75.4 & 90.0 & 62.2 & 27.8 & 0.7 & 15.7 & 21.2 & 4.2 \\
\hline Little Osage Creek ${ }^{1}$ & 23.5 & 59.7 & 77.9 & 21.6 & 56.2 & 0.0 & 37.6 & 48.7 & 8.7 \\
\hline Mud Creek ${ }^{3}$ & 44.5 & 96.8 & 83.0 & 44.5 & 38.4 & 0.0 & 38.1 & 29.5 & 17.3 \\
\hline Osage Creek-Rogers ${ }^{3}$ & 65.2 & 87.9 & 77.6 & 63.5 & 14.0 & 0.0 & 8.5 & 16.8 & 14.0 \\
\hline Clear Creek ${ }^{3}$ & 42.6 & 77.3 & 79.8 & 42.6 & 37.3 & 0.0 & 34.2 & 30.2 & 19.5 \\
\hline Spring Creek ${ }^{3}$ & 79.0 & 90.3 & 90.8 & 79.0 & 11.9 & 0.7 & 2.2 & 1.9 & 2.6 \\
\hline
\end{tabular}

\begin{tabular}{|c|c|c|c|c|c|c|c|c|c|c|}
\hline Short site name & Bluegill & $\begin{array}{c}\text { Green } \\
\text { sunfish } \\
\text { (includes } \\
\text { hybrids) }\end{array}$ & $\begin{array}{c}\text { Yellow } \\
\text { bull- } \\
\text { head }\end{array}$ & GSFYBHBGCC & $\begin{array}{c}\text { Top } \\
\text { carni- } \\
\text { vores }\end{array}$ & PAHINP & $\begin{array}{c}\text { Darters } \\
\text { plus } \\
\text { madtoms } \\
\text { plus } \\
\text { sculpins } \\
\text { (richness) }\end{array}$ & $\begin{array}{l}\text { Lithophilic } \\
\text { spawners } \\
\text { (richness) }\end{array}$ & $\begin{array}{c}\mid \mathrm{BI} \\
\text { score }\end{array}$ & IBI category \\
\hline Cincinnati Creek $^{1}$ & 0.55 & 0.07 & 0.21 & 0.83 & 9.57 & 0.76 & 6 & 12 & 89 & Least disturbed $^{4}$ \\
\hline Weddington Creek ${ }^{1}$ & 0.41 & 0.72 & 0.00 & 1.12 & 3.27 & 0.41 & 5 & 11 & 88 & Least disturbed $^{4}$ \\
\hline Baron Fork ${ }^{1}$ & 0.20 & 0.46 & 0.13 & 0.80 & 0.86 & 0.33 & 5 & 12 & 80 & Least disturbed $^{4}$ \\
\hline Flint Creek $^{1}$ & 0.18 & 0.18 & 0.18 & 0.55 & 7.71 & 0.37 & 4 & 11 & 79 & Good \\
\hline Evansville Creek $^{2}$ & 0.00 & 3.87 & 0.22 & 4.09 & 1.33 & 0.22 & 6 & 10 & 78 & Good \\
\hline Ballard Creek $^{1}$ & 0.14 & 5.16 & 0.43 & 5.73 & 0.57 & 0.57 & 5 & 9 & 71 & Good \\
\hline Illinois River ${ }^{2}$ & 0.42 & 12.03 & 0.42 & 12.88 & 0.85 & 0.85 & 5 & 12 & 71 & Good \\
\hline Moores Creek ${ }^{1}$ & 3.39 & 11.76 & 1.13 & 16.29 & 1.36 & 4.52 & 7 & 8 & 60 & Good \\
\hline Hamestring Creek ${ }^{3}$ & 1.83 & 10.42 & 0.10 & 12.36 & 0.10 & 1.93 & 7 & 9 & 58 & Fair \\
\hline Mud Creek ${ }^{3}$ & 5.82 & 4.08 & 0.00 & 9.91 & 0.44 & 5.82 & 2 & 9 & 52 & Fair \\
\hline Osage Creek-Rogers ${ }^{3}$ & 2.79 & 10.84 & 0.00 & 13.63 & 0.19 & 2.79 & 5 & 6 & 48 & Fair \\
\hline Clear Creek ${ }^{3}$ & 5.45 & 9.91 & 0.22 & 15.58 & 0.00 & 5.66 & 3 & 6 & 45 & Fair \\
\hline Spring Creek $^{3}$ & 0.15 & 0.82 & 7.46 & 8.43 & 0.67 & 7.61 & 3 & 6 & 36 & Poor \\
\hline
\end{tabular}

\footnotetext{
${ }^{1}$ Agriculture site (Baron Fork and Goose Creek are downstream from wastewater-treatment plants).

${ }^{2}$ Forest site.

${ }^{3}$ Urban site (Osage Creek-Cave Springs and Spring Creek are downstream from wastewater-treatment plants).

${ }^{4}$ Categorized here as "least disturbed," but score is equivalent to "reference" in Dauwalter and others (2003).
} 
Table 22. Correlations between fish metrics and Ozark Highlands fish index of biotic integrity and selected environmental factors for sites not affected by wastewater-treatment plants in the Illinois River Basin study area.

[Fish metrics are sorted by absolute value of correlation with percent forest; red font denotes absolute value of rho is greater than or equal to 0.50; metric descriptions are listed in table 20; GSFYBHBGCC is green sunfish plus yellow bullhead plus bluegill plus channel catfish; PAHINP is algivorous/herbivorous, invertivorous, piscivorous; number of sites equals 14]

\begin{tabular}{|c|c|c|c|c|c|c|c|c|c|c|c|c|}
\hline $\begin{array}{c}\text { Fish metrics, } \\
\text { relative abundance } \\
\text { (unless otherwise noted) }\end{array}$ & $\begin{array}{l}\text { Nitrite plus } \\
\text { nitrate }\end{array}$ & $\begin{array}{c}\text { Total } \\
\text { phosphorus }\end{array}$ & Temperature & $\begin{array}{c}\text { Specific } \\
\text { conduc- } \\
\text { tance }\end{array}$ & $\begin{array}{l}\text { Dissolved } \\
\text { oxygen }\end{array}$ & $\mathrm{pH}$ & Streamflow & $\begin{array}{l}\text { Bankfull } \\
\text { width }\end{array}$ & $\begin{array}{l}\text { Drainage } \\
\text { area }\end{array}$ & $\begin{array}{l}\text { Bankfull } \\
\text { width/ } \\
\text { drainage } \\
\text { area }\end{array}$ & Depth & Velocity \\
\hline Lithophilicspawners (richness) & -0.11 & -0.07 & 0.09 & -0.13 & 0.19 & -0.10 & -0.45 & 0.50 & 0.12 & 0.03 & -0.53 & -0.55 \\
\hline Smallmouth bass & 0.14 & 0.32 & 0.43 & -0.36 & 0.29 & 0.35 & 0.04 & 0.45 & 0.02 & 0.09 & -0.40 & -0.05 \\
\hline Top carnivores & 0.21 & 0.42 & 0.38 & -0.33 & 0.13 & 0.20 & -0.06 & 0.31 & 0.21 & -0.09 & -0.35 & -0.09 \\
\hline IBI score & 0.26 & 0.37 & 0.38 & -0.32 & 0.34 & 0.39 & 0.11 & 0.42 & 0.18 & -0.02 & -0.40 & -0.00 \\
\hline Darters + madtoms + sculpins & 0.30 & 0.20 & 0.04 & 0.25 & -0.08 & 0.61 & 0.61 & -0.20 & -0.19 & 0.12 & 0.39 & 0.49 \\
\hline Lithophilic spawners & -0.02 & 0.10 & 0.66 & -0.28 & 0.17 & 0.51 & -0.05 & 0.70 & -0.31 & 0.49 & -0.54 & -0.10 \\
\hline Yellow bullhead & -0.68 & 0.22 & 0.44 & -0.70 & -0.13 & -0.16 & -0.57 & 0.17 & 0.08 & 0.03 & -0.34 & -0.48 \\
\hline GSFYBHBGCC & -0.42 & -0.22 & -0.37 & 0.08 & -0.42 & -0.56 & -0.35 & -0.33 & 0.08 & -0.06 & 0.35 & -0.23 \\
\hline $\begin{array}{l}\text { Lithophilic spawners minus } \\
\text { stonerollers }\end{array}$ & -0.04 & 0.23 & 0.46 & -0.30 & 0.03 & 0.24 & -0.01 & 0.32 & 0.31 & -0.08 & -0.25 & 0.00 \\
\hline Bluegill & -0.34 & -0.07 & -0.15 & 0.33 & -0.56 & -0.49 & -0.31 & -0.18 & -0.20 & 0.10 & 0.41 & -0.22 \\
\hline PAHINP & -0.48 & -0.12 & -0.09 & 0.27 & -0.54 & -0.50 & -0.40 & -0.12 & -0.20 & 0.14 & 0.32 & -0.33 \\
\hline $\begin{array}{l}\text { Green sunfish } \\
\quad \text { (includes hybrids) }\end{array}$ & -0.35 & -0.30 & -0.47 & -0.01 & -0.16 & -0.52 & -0.31 & -0.24 & 0.22 & -0.14 & 0.25 & -0.26 \\
\hline $\begin{array}{l}\text { Darters }+ \text { madtoms }+ \text { sculpins } \\
\quad \text { (richness) }\end{array}$ & 0.13 & 0.09 & -0.14 & 0.04 & 0.08 & -0.53 & -0.21 & -0.14 & 0.16 & -0.29 & 0.00 & -0.05 \\
\hline Algivores+detritivores & 0.18 & -0.23 & 0.05 & 0.15 & 0.34 & 0.04 & 0.08 & 0.07 & -0.28 & 0.12 & -0.36 & 0.02 \\
\hline Tolerant & -0.47 & -0.60 & -0.07 & 0.19 & -0.32 & -0.34 & -0.49 & 0.15 & -0.11 & 0.28 & -0.18 & -0.42 \\
\hline Centrarchidae & -0.63 & -0.35 & -0.16 & -0.11 & -0.45 & -0.64 & -0.75 & 0.05 & -0.02 & 0.13 & -0.03 & -0.56 \\
\hline Invertivores & -0.48 & -0.18 & 0.37 & -0.17 & -0.42 & 0.30 & -0.28 & 0.33 & 0.10 & 0.31 & -0.23 & -0.26 \\
\hline Stonerollers & 0.30 & -0.24 & -0.11 & 0.28 & 0.21 & 0.07 & 0.20 & -0.02 & -0.45 & 0.23 & -0.13 & 0.19 \\
\hline Fish per meter & -0.12 & -0.00 & 0.30 & 0.41 & -0.01 & -0.09 & -0.28 & 0.57 & -0.54 & 0.56 & -0.37 & -0.39 \\
\hline
\end{tabular}


Table 22. Correlations between fish metrics and Ozark Highlands fish index of biotic integrity and selected environmental factors for sites not affected by wastewater-treatment plants in the Illinois River Basin study area.-Continued

[Fish metrics are sorted by absolute value of correlation with percent forest; red font denotes absolute value of rho is greater than or equal to 0.50; metric descriptions are listed in table 20; GSFYBHBGCC is green sunfish plus yellow bullhead plus bluegill plus channel catfish; PAHINP is algivorous/herbivorous, invertivorous, piscivorous; number of sites equals 14]

\begin{tabular}{|c|c|c|c|c|c|c|c|c|c|c|c|c|c|c|}
\hline $\begin{array}{c}\text { Fish metrics, } \\
\text { relative abundance } \\
\text { (unless otherwise noted) }\end{array}$ & $\begin{array}{c}\text { Bed } \\
\text { substrate }\end{array}$ & $\begin{array}{l}\text { Embed- } \\
\text { dedness }\end{array}$ & $\begin{array}{c}\text { Substrate } \\
\text { turbidity }\end{array}$ & $\begin{array}{c}\text { Open } \\
\text { canopy } \\
\text { angle }\end{array}$ & $\begin{array}{l}\text { Combined } \\
\text { canopy } \\
\text { closure }\end{array}$ & $\begin{array}{c}\text { Bank } \\
\text { height }\end{array}$ & $\begin{array}{l}\text { Bank } \\
\text { angle }\end{array}$ & $\begin{array}{l}\text { Percent } \\
\text { forest }\end{array}$ & $\begin{array}{c}\text { Percent } \\
\text { urban }\end{array}$ & $\begin{array}{l}\text { Percent } \\
\text { agricul- } \\
\text { ture }\end{array}$ & $\begin{array}{l}\text { Poultry } \\
\text { house } \\
\text { density }\end{array}$ & $\begin{array}{l}\text { Total } \\
\text { unpaved } \\
\text { road } \\
\text { density }\end{array}$ & $\begin{array}{l}\text { Total } \\
\text { paved } \\
\text { road } \\
\text { density }\end{array}$ & $\begin{array}{l}\text { Total } \\
\text { road } \\
\text { density }\end{array}$ \\
\hline Lithophilic spawners (richness) & 0.38 & -0.53 & -0.09 & 0.18 & -0.33 & 0.39 & 0.46 & 0.85 & -0.79 & -0.11 & 0.25 & 0.23 & -0.73 & -0.71 \\
\hline Smallmouth bass & 0.20 & -0.35 & -0.39 & 0.50 & -0.50 & -0.17 & 0.02 & 0.67 & -0.73 & 0.29 & 0.41 & 0.50 & -0.75 & -0.74 \\
\hline Top carnivores & 0.04 & -0.05 & 0.01 & 0.45 & -0.35 & 0.11 & 0.12 & 0.64 & -0.64 & 0.32 & 0.42 & 0.66 & -0.72 & -0.63 \\
\hline IBI score & 0.17 & -0.41 & -0.34 & 0.46 & -0.45 & 0.36 & 0.17 & 0.61 & -0.73 & 0.47 & 0.44 & 0.56 & -0.73 & -0.74 \\
\hline Darters + madtoms + sculpins & -0.09 & -0.04 & -0.52 & -0.04 & 0.22 & -0.47 & -0.36 & -0.54 & 0.36 & 0.38 & -0.06 & -0.17 & 0.45 & 0.41 \\
\hline Lithophilic spawners & 0.19 & -0.27 & -0.31 & 0.51 & -0.61 & -0.24 & -0.15 & 0.53 & -0.57 & 0.10 & 0.20 & 0.35 & -0.56 & -0.59 \\
\hline Yellow bullhead & 0.21 & -0.18 & 0.06 & -0.50 & 0.19 & 0.37 & -0.06 & 0.51 & -0.38 & -0.10 & 0.49 & 0.37 & -0.42 & -0.44 \\
\hline GSFYBHBGCC & 0.01 & 0.29 & 0.35 & -0.48 & 0.27 & 0.21 & 0.07 & -0.39 & 0.46 & -0.33 & -0.34 & -0.46 & 0.47 & 0.41 \\
\hline $\begin{array}{l}\text { Lithophilic spawners minus } \\
\text { stonerollers }\end{array}$ & 0.24 & -0.58 & -0.34 & 0.12 & -0.26 & -0.12 & 0.18 & 0.36 & -0.52 & 0.40 & 0.36 & 0.28 & -0.50 & -0.59 \\
\hline Bluegill & -0.18 & 0.55 & 0.26 & -0.28 & 0.25 & 0.33 & -0.12 & -0.36 & 0.56 & -0.49 & -0.27 & -0.48 & 0.51 & 0.55 \\
\hline PAHINP & -0.19 & 0.49 & 0.28 & -0.34 & 0.24 & 0.37 & -0.16 & -0.32 & -0.56 & 0.53 & -0.28 & -0.52 & 0.52 & 0.51 \\
\hline $\begin{array}{l}\text { Green sunfish } \\
\quad \text { (includes hybrids) }\end{array}$ & 0.03 & 0.13 & 0.35 & -0.39 & 0.19 & 0.28 & 0.24 & -0.27 & 0.32 & -0.28 & -0.33 & -0.42 & 0.36 & 0.27 \\
\hline $\begin{array}{l}\text { Darters }+ \text { madtoms }+ \text { sculpins } \\
\quad \text { (richness) }\end{array}$ & 0.11 & -0.01 & 0.14 & -0.32 & 0.05 & 0.31 & 0.73 & 0.21 & -0.22 & 0.21 & 0.14 & 0.26 & -0.27 & -0.22 \\
\hline Algivores + detritivores & -0.15 & 0.07 & 0.11 & 0.40 & -0.36 & -0.32 & -0.30 & 0.17 & -0.15 & -0.25 & -0.17 & 0.07 & -0.14 & -0.12 \\
\hline Tolerant & -0.01 & 0.15 & 0.54 & 0.01 & -0.19 & 0.11 & -0.17 & -0.15 & 0.27 & -0.68 & -0.54 & -0.53 & 0.32 & 0.23 \\
\hline Centrarchidae & 0.23 & 0.15 & 0.49 & -0.41 & 0.14 & 0.55 & 0.21 & 0.13 & 0.08 & -0.58 & -0.18 & -0.27 & 0.05 & 0.07 \\
\hline Invertivores & 0.24 & -0.34 & 0.06 & -0.19 & 0.02 & -0.02 & -0.21 & -0.11 & 0.06 & -0.05 & -0.03 & -0.19 & 0.14 & 0.00 \\
\hline Stonerollers & -0.17 & 0.34 & 0.15 & 0.40 & -0.21 & -0.33 & -0.34 & -0.09 & 0.16 & -0.28 & -0.25 & -0.03 & 0.10 & 0.20 \\
\hline Fish per meter & -0.02 & 0.17 & -0.12 & 0.16 & -0.42 & -0.08 & 0.01 & 0.05 & 0.09 & -0.21 & 0.01 & 0.47 & 0.76 & 0.94 \\
\hline
\end{tabular}


Table 23. Correlation between fish metrics and Ozark Highlands fish index of biotic integrity and selected environmental factors at agriculture gradient sites in the Illinois River Basin study area.

[Fish metrics are sorted by absolute value of correlation with percent agriculture; red font denotes absolute value of rho is greater than or equal to 0.60 ; metric descriptions are listed in table 20 ; number of sites equals 10]

\begin{tabular}{|c|c|c|c|c|c|c|c|c|c|c|c|c|}
\hline $\begin{array}{c}\text { Fish metrics, } \\
\text { relative abundance } \\
\text { (unless otherwise noted) }\end{array}$ & $\begin{array}{l}\text { Nitrite } \\
\text { plus } \\
\text { nitrate }\end{array}$ & $\begin{array}{l}\text { Total } \\
\text { phospho- } \\
\text { rus }\end{array}$ & $\begin{array}{l}\text { Tempera- } \\
\text { ture }\end{array}$ & $\begin{array}{l}\text { Specific } \\
\text { conduc- } \\
\text { tance }\end{array}$ & $\begin{array}{l}\text { Dissolved } \\
\text { oxygen }\end{array}$ & $\mathrm{pH}$ & $\begin{array}{l}\text { Stream- } \\
\text { flow }\end{array}$ & $\begin{array}{c}\text { Bankfull } \\
\text { width }\end{array}$ & $\begin{array}{l}\text { Drainage } \\
\text { area }\end{array}$ & $\begin{array}{l}\text { Bankfull } \\
\text { width/ } \\
\text { drainage } \\
\text { area }\end{array}$ & Depth & Velocity \\
\hline Darters + madtoms + sculpins & 0.70 & 0.27 & -0.03 & 0.39 & 0.31 & 0.69 & 0.92 & -0.38 & 0.08 & -0.35 & 0.53 & 0.77 \\
\hline Centrarchidae & -0.71 & -0.21 & -0.07 & -0.37 & -0.43 & -0.76 & -0.86 & 0.15 & 0.20 & 0.08 & -0.32 & -0.70 \\
\hline Lithophilic spawners (richness) & -0.28 & -0.32 & -0.22 & 0.09 & 0.00 & -0.53 & -0.49 & 0.35 & -0.15 & 0.27 & -0.29 & -0.46 \\
\hline Tolerant & -0.58 & -0.48 & -0.03 & -0.22 & -0.08 & -0.38 & -0.77 & 0.38 & -0.01 & 0.41 & -0.64 & -0.77 \\
\hline Yellow bullhead & -0.80 & 0.24 & 0.45 & -0.56 & -0.26 & -0.33 & -0.61 & 0.17 & 0.18 & 0.01 & -0.28 & -0.55 \\
\hline PAHINP & -0.51 & 0.29 & -0.05 & -0.01 & -0.31 & -0.72 & -0.64 & 0.07 & 0.22 & -0.12 & -0.16 & -0.77 \\
\hline Algivores+detritivores & 0.04 & -0.39 & 0.27 & 0.10 & 0.41 & 0.15 & -0.15 & 0.32 & -0.83 & 0.58 & -0.76 & -0.12 \\
\hline Bluegill & -0.28 & 0.35 & -0.19 & 0.12 & -0.36 & -0.72 & -0.46 & -0.06 & 0.20 & -0.22 & 0.06 & -0.57 \\
\hline Fish per meter & -0.09 & 0.02 & 0.29 & 0.37 & 0.15 & -0.29 & -0.32 & 0.62 & -0.58 & 0.59 & -0.59 & -0.43 \\
\hline Stonerollers & 0.30 & -0.33 & 0.05 & 0.14 & 0.48 & 0.26 & 0.05 & 0.24 & -0.81 & 0.48 & -0.54 & 0.04 \\
\hline Green sunfish (includes hybrids) & -0.33 & -0.22 & -0.38 & -0.13 & -0.13 & -0.38 & -0.49 & -0.04 & 0.47 & -0.12 & -0.20 & -0.61 \\
\hline IBI score & 0.09 & 0.06 & 0.39 & -0.06 & 0.04 & 0.37 & 0.26 & 0.41 & -0.40 & 0.41 & 0.18 & 0.38 \\
\hline Smallmouth bass & 0.02 & 0.14 & 0.44 & -0.07 & 0.06 & 0.30 & 0.18 & 0.38 & -0.47 & 0.38 & 0.10 & 0.27 \\
\hline Invertivores & -0.32 & -0.20 & 0.04 & -0.21 & -0.13 & 0.01 & -0.14 & 0.12 & 0.50 & -0.01 & 0.01 & -0.09 \\
\hline Lithophilic spawners & -0.03 & -0.08 & 0.64 & -0.13 & 0.09 & 0.38 & 0.07 & 0.62 & -0.70 & 0.72 & -0.22 & 0.25 \\
\hline GSFYBHBGCC & -0.37 & -0.08 & -0.32 & -0.01 & -0.30 & -0.52 & -0.52 & -0.14 & 0.52 & -0.21 & -0.10 & -0.64 \\
\hline Lithophilic spawners minus stonerollers & -0.16 & -0.03 & 0.36 & 0.09 & -0.29 & -0.03 & 0.09 & 0.13 & 0.16 & 0.07 & 0.20 & 0.31 \\
\hline Darters + madtoms + sculpins (richness) & -0.10 & 0.00 & -0.01 & 0.27 & -0.70 & -0.74 & -0.34 & -0.32 & 0.07 & -0.16 & 0.01 & -0.08 \\
\hline Top carnivores & 0.07 & 0.30 & 0.27 & -0.21 & -0.25 & 0.10 & 0.12 & 0.14 & -0.36 & 0.18 & 0.33 & 0.30 \\
\hline
\end{tabular}


Table 23. Correlation between fish metrics and Ozark Highlands fish index of biotic integrity and selected environmental factors at agriculture gradient sites in the Illinois River Basin study area.-Continued

[Fish metrics are sorted by absolute value of correlation with percent agriculture; red font denotes absolute value of rho is greater than or equal to 0.60 ; metric descriptions are listed in table 20; number of sites equals 10]

\begin{tabular}{|c|c|c|c|c|c|c|c|c|c|c|c|c|c|c|}
\hline $\begin{array}{c}\text { Fish metrics, } \\
\text { relative abundance } \\
\text { (unless otherwise noted) }\end{array}$ & $\begin{array}{c}\text { Bed } \\
\text { substrate }\end{array}$ & $\begin{array}{l}\text { Embed- } \\
\text { dedness }\end{array}$ & $\begin{array}{c}\text { Substrate } \\
\text { turbidity }\end{array}$ & $\begin{array}{l}\text { Open } \\
\text { canopy } \\
\text { angle }\end{array}$ & $\begin{array}{l}\text { Combined } \\
\text { canopy } \\
\text { closure }\end{array}$ & $\begin{array}{c}\text { Bank } \\
\text { height }\end{array}$ & $\begin{array}{l}\text { Bank } \\
\text { angle }\end{array}$ & $\begin{array}{c}\text { Percent } \\
\text { forest }\end{array}$ & $\begin{array}{c}\text { Percent } \\
\text { urban }\end{array}$ & $\begin{array}{l}\text { Percent } \\
\text { agricul- } \\
\text { ture }\end{array}$ & $\begin{array}{l}\text { Poultry } \\
\text { house } \\
\text { density }\end{array}$ & $\begin{array}{l}\text { Total } \\
\text { unpaved } \\
\text { road } \\
\text { density }\end{array}$ & $\begin{array}{l}\text { Total } \\
\text { paved } \\
\text { road } \\
\text { density }\end{array}$ & $\begin{array}{l}\text { Total } \\
\text { road } \\
\text { density }\end{array}$ \\
\hline Darters + madtoms + sculpins & -0.43 & -0.03 & -0.66 & 0.20 & 0.12 & -0.78 & -0.43 & -0.69 & 0.47 & 0.79 & 0.05 & 0.10 & 0.44 & 0.48 \\
\hline Centrarchidae & 0.41 & -0.09 & 0.64 & -0.37 & 0.09 & 0.84 & 0.44 & 0.60 & -0.36 & -0.72 & -0.02 & -0.18 & -0.30 & -0.36 \\
\hline Lithophilic spawners (richness) & 0.58 & -0.22 & -0.07 & 0.24 & -0.25 & 0.32 & 0.41 & 0.78 & -0.71 & -0.69 & -0.07 & -0.20 & -0.81 & -0.63 \\
\hline Tolerant & 0.44 & -0.37 & 0.55 & -0.30 & -0.25 & 0.38 & 0.35 & 0.42 & -0.37 & -0.50 & -0.37 & -0.46 & -0.12 & -0.39 \\
\hline Yellow bullhead & -0.14 & 0.04 & 0.39 & -0.46 & 0.24 & 0.74 & -0.15 & 0.31 & -0.10 & -0.50 & 0.33 & -0.02 & -0.02 & -0.19 \\
\hline PAHINP & 0.04 & 0.12 & 0.31 & -0.38 & 0.11 & 0.73 & 0.41 & 0.34 & -0.18 & -0.41 & 0.21 & 0.12 & -0.52 & -0.17 \\
\hline Algivores + detritivores & 0.15 & 0.10 & 0.08 & 0.08 & -0.21 & -0.19 & -0.23 & 0.39 & -0.42 & -0.37 & 0.01 & 0.04 & 0.07 & -0.37 \\
\hline Bluegill & 0.03 & 0.28 & 0.24 & -0.24 & 0.12 & 0.63 & 0.49 & 0.25 & -0.10 & -0.28 & 0.20 & 0.26 & -0.63 & -0.07 \\
\hline Fish per meter & 0.16 & 0.13 & -0.15 & 0.29 & -0.60 & -0.22 & 0.27 & 0.26 & -0.28 & -0.24 & 0.14 & 0.03 & -0.54 & -0.44 \\
\hline Stonerollers & 0.09 & 0.26 & 0.02 & 0.26 & -0.20 & -0.21 & -0.16 & 0.29 & -0.33 & -0.21 & -0.04 & 0.25 & -0.20 & -0.21 \\
\hline Green sunfish (includes hybrids) & 0.20 & -0.32 & 0.56 & -0.52 & 0.10 & 0.49 & 0.47 & 0.02 & 0.07 & -0.13 & -0.30 & -0.25 & 0.19 & 0.10 \\
\hline IBI score & 0.06 & 0.09 & -0.58 & 0.81 & -0.52 & -0.52 & -0.32 & 0.13 & -0.32 & 0.02 & -0.06 & -0.09 & -0.36 & -0.41 \\
\hline Smallmouth bass & -0.01 & 0.19 & -0.54 & 0.69 & -0.40 & -0.35 & -0.38 & 0.25 & -0.39 & -0.11 & 0.07 & 0.02 & -0.45 & -0.44 \\
\hline Invertivores & 0.15 & -0.60 & 0.07 & -0.18 & -0.10 & -0.09 & 0.09 & -0.20 & 0.19 & 0.10 & -0.22 & -0.59 & 0.53 & 0.15 \\
\hline Lithophilic spawners & 0.08 & 0.15 & -0.36 & 0.72 & -0.66 & -0.56 & -0.37 & 0.18 & -0.33 & -0.09 & -0.05 & -0.12 & -0.18 & -0.50 \\
\hline GSFYBHBGCC & 0.16 & -0.29 & 0.52 & -0.60 & 0.14 & 0.48 & 0.49 & -0.01 & 0.08 & -0.09 & -0.24 & -0.26 & 0.20 & 0.09 \\
\hline Lithophilic spawners minus stonerollers & 0.20 & -0.44 & -0.46 & 0.21 & -0.25 & -0.50 & -0.10 & -0.04 & -0.03 & 0.07 & 0.03 & -0.56 & 0.17 & -0.27 \\
\hline Darters + madtoms + sculpins (richness) & 0.20 & 0.19 & 0.50 & -0.45 & 0.15 & 0.14 & 0.47 & -0.02 & 0.18 & -0.06 & 0.10 & -0.01 & 0.23 & 0.06 \\
\hline Top carnivores & -0.10 & 0.60 & -0.15 & 0.58 & -0.20 & -0.01 & -0.20 & 0.15 & -0.19 & -0.05 & 0.09 & 0.37 & -0.54 & -0.19 \\
\hline
\end{tabular}


Table 24. Correlation between fish metrics and Ozark Highlands fish index of biotic integrity and selected environmental factors at urban gradient sites in the Illinois River Basin study area.

[Fish metrics are sorted by absolute value of correlation with percent urban; red font denotes absolute value of rho is greater than or equal to 0.80 ; metric descriptions are listed in table 20; number of sites equals 6]

\begin{tabular}{|c|c|c|c|c|c|c|c|c|c|c|c|c|}
\hline $\begin{array}{c}\text { Fish metrics, } \\
\text { relative abundance } \\
\text { (unless otherwise noted) }\end{array}$ & $\begin{array}{l}\text { Nitrite } \\
\text { plus } \\
\text { nitrate }\end{array}$ & $\begin{array}{c}\text { Total } \\
\text { phosphorus }\end{array}$ & $\begin{array}{l}\text { Tempera- } \\
\text { ture }\end{array}$ & $\begin{array}{l}\text { Specific } \\
\text { conduc- } \\
\text { tance }\end{array}$ & $\begin{array}{c}\text { Dissolved } \\
\text { oxygen }\end{array}$ & pH & $\begin{array}{l}\text { Stream- } \\
\text { flow }\end{array}$ & $\begin{array}{l}\text { Bankfull } \\
\text { width }\end{array}$ & $\begin{array}{l}\text { Drainage } \\
\text { area }\end{array}$ & $\begin{array}{l}\text { Bankfull } \\
\text { width/ } \\
\text { drainage } \\
\text { area }\end{array}$ & Depth & Velocity \\
\hline Lithophilic spawners minus stonerollers & -0.49 & -0.71 & 0.54 & -0.66 & 0.09 & 0.14 & -0.77 & 0.71 & 0.09 & 0.03 & -0.83 & -0.71 \\
\hline Yellow bullhead & -0.84 & -0.41 & 0.32 & -0.99 & -0.12 & 0.06 & -0.75 & 0.49 & 0.06 & 0.03 & -0.70 & -0.49 \\
\hline Smallmouth bass & -0.54 & -0.85 & 0.51 & -0.78 & -0.03 & 0.03 & -0.78 & 0.54 & 0.30 & -0.14 & -0.85 & -0.54 \\
\hline Stonerollers & 0.60 & 0.26 & -0.09 & 0.77 & -0.26 & 0.09 & 0.60 & -0.60 & -0.03 & 0.09 & 0.49 & 0.60 \\
\hline Bluegill & 0.26 & 0.60 & -0.09 & 0.77 & -0.43 & 0.43 & 0.43 & -0.26 & -0.20 & 0.43 & 0.49 & 0.26 \\
\hline PAHINP & 0.26 & 0.60 & -0.09 & 0.77 & -0.43 & 0.43 & 0.43 & -0.26 & -0.20 & 0.43 & 0.49 & 0.26 \\
\hline IBI score & -0.26 & -0.83 & 0.37 & -0.54 & 0.31 & -0.09 & -0.66 & 0.66 & 0.31 & -0.26 & -0.71 & -0.66 \\
\hline Lithophilic spawners (richness) & -0.53 & -0.79 & 0.38 & -0.62 & 0.15 & 0.09 & -0.85 & 0.88 & 0.44 & -0.18 & -0.79 & -0.88 \\
\hline Fish per meter & 0.20 & 0.66 & -0.03 & 0.71 & -0.37 & 0.49 & 0.37 & -0.14 & -0.37 & 0.54 & 0.43 & 0.14 \\
\hline Tolerant & 0.09 & -0.14 & -0.03 & 0.49 & -0.31 & 0.26 & -0.03 & 0.14 & 0.60 & -0.09 & 0.09 & -0.14 \\
\hline Lithophilic spawners & -0.54 & -0.71 & 0.94 & -0.31 & -0.54 & 0.71 & -0.83 & 0.71 & 0.03 & 0.49 & -0.94 & -0.71 \\
\hline Darters + madtoms + sculpins (richness) & 0.23 & -0.15 & -0.26 & -0.38 & 0.75 & -0.67 & 0.12 & -0.12 & -0.12 & -0.46 & 0.03 & 0.12 \\
\hline Top carnivores & -0.26 & -1.00 & 0.49 & -0.37 & 0.03 & 0.09 & -0.71 & 0.66 & 0.60 & -0.26 & -0.77 & -0.66 \\
\hline GSFYBHBGCC & -0.09 & 0.71 & -0.60 & -0.03 & -0.09 & -0.26 & 0.43 & -0.54 & -0.09 & -0.09 & 0.60 & 0.54 \\
\hline Algivores + detritivores & 0.37 & -0.31 & 0.14 & 0.31 & -0.20 & -0.03 & 0.20 & -0.37 & 0.26 & -0.14 & 0.03 & 0.37 \\
\hline Darters + madtoms + sculpins & 0.03 & 0.60 & 0.37 & 0.43 & -0.60 & 0.66 & 0.26 & -0.26 & -0.83 & 0.89 & 0.14 & 0.26 \\
\hline Green sunfish (includes hybrids) & -0.03 & 0.20 & -0.83 & -0.20 & 0.54 & -0.66 & 0.14 & -0.03 & 0.54 & -0.71 & 0.43 & 0.03 \\
\hline Invertivores & -0.66 & -0.26 & 0.60 & -0.09 & -0.66 & 0.83 & -0.71 & 0.77 & 0.14 & 0.54 & -0.60 & -0.77 \\
\hline Centrarchidae & -0.66 & 0.26 & -0.09 & -0.26 & -0.31 & 0.31 & -0.37 & 0.43 & 0.14 & 0.20 & -0.09 & -0.43 \\
\hline
\end{tabular}


Table 24. Correlation between fish metrics and Ozark Highlands fish index of biotic integrity and selected environmental factors at urban gradient sites in the Illinois River Basin study area.-Continued

[Fish metrics are sorted by absolute value of correlation with percent urban; red font denotes absolute value of rho is greater than or equal to 0.80 ; metric descriptions are listed in table 20; number of sites equals 6]

\begin{tabular}{|c|c|c|c|c|c|c|c|c|c|c|c|c|c|c|}
\hline $\begin{array}{c}\text { Fish metrics, } \\
\text { relative abundance } \\
\text { (unless otherwise noted) }\end{array}$ & $\begin{array}{c}\text { Bed } \\
\text { substrate }\end{array}$ & $\begin{array}{l}\text { Embed- } \\
\text { dedness }\end{array}$ & $\begin{array}{c}\text { Sub- } \\
\text { strate } \\
\text { turbidity }\end{array}$ & $\begin{array}{c}\text { Open } \\
\text { canopy } \\
\text { angle }\end{array}$ & $\begin{array}{l}\text { Com- } \\
\text { bined } \\
\text { canopy } \\
\text { closure }\end{array}$ & $\begin{array}{c}\text { Bank } \\
\text { height }\end{array}$ & $\begin{array}{c}\text { Bank } \\
\text { angle }\end{array}$ & $\begin{array}{c}\text { Percent } \\
\text { forest }\end{array}$ & $\begin{array}{c}\text { Percent } \\
\text { Urban }\end{array}$ & $\begin{array}{l}\text { Percent } \\
\text { agricul- } \\
\text { ture }\end{array}$ & $\begin{array}{l}\text { Poultry } \\
\text { house } \\
\text { density }\end{array}$ & $\begin{array}{l}\text { Total } \\
\text { unpaved } \\
\text { road } \\
\text { density }\end{array}$ & $\begin{array}{l}\text { Total } \\
\text { paved } \\
\text { road } \\
\text { density }\end{array}$ & $\begin{array}{l}\text { Total } \\
\text { road } \\
\text { density }\end{array}$ \\
\hline Lithophilic spawners minus stonerollers & 0.54 & -0.77 & 0.20 & -0.14 & -0.54 & 0.43 & 0.60 & 1.00 & -0.94 & -0.20 & 0.37 & 0.66 & -0.71 & -0.66 \\
\hline Yellow bullhead & 0.93 & -0.99 & -0.32 & -0.20 & -0.46 & -0.12 & 0.35 & 0.73 & -0.87 & 0.32 & 0.81 & 0.81 & -0.93 & -0.99 \\
\hline Smallmouth bass & 0.54 & -0.78 & 0.27 & 0.14 & -0.78 & -0.03 & 0.37 & 0.85 & -0.85 & -0.27 & 0.37 & 0.68 & -0.85 & -0.78 \\
\hline Stonerollers & -0.77 & 0.83 & 0.37 & 0.26 & 0.31 & -0.43 & -0.71 & -0.77 & 0.83 & -0.37 & -0.60 & -0.54 & 0.66 & 0.77 \\
\hline Bluegill & -0.43 & 0.66 & 0.03 & -0.09 & 0.66 & -0.09 & -0.71 & -0.77 & 0.83 & -0.03 & -0.26 & -0.54 & 0.83 & 0.77 \\
\hline PAHINP & -0.43 & 0.66 & 0.03 & -0.09 & 0.66 & -0.09 & -0.71 & -0.77 & 0.83 & -0.03 & -0.26 & -0.54 & 0.83 & 0.77 \\
\hline IBI score & 0.31 & -0.60 & 0.37 & 0.14 & -0.71 & 0.49 & 0.71 & 0.94 & -0.83 & -0.37 & 0.09 & 0.43 & -0.60 & -0.54 \\
\hline Lithophilic spawners (richness) & 0.53 & -0.74 & 0.29 & 0.18 & -0.74 & 0.50 & 0.62 & 0.91 & -0.79 & -0.29 & 0.27 & 0.41 & -0.56 & -0.62 \\
\hline Fish per meter & -0.31 & 0.54 & -0.09 & -0.31 & 0.77 & 0.14 & -0.54 & -0.60 & 0.66 & 0.09 & -0.14 & -0.43 & 0.77 & 0.71 \\
\hline Tolerant & -0.37 & 0.43 & 0.54 & 0.66 & -0.20 & -0.14 & -0.54 & -0.49 & 0.66 & -0.54 & -0.43 & -0.60 & 0.60 & 0.49 \\
\hline Lithophilic spawners & 0.37 & -0.54 & 0.54 & -0.14 & -0.37 & 0.14 & -0.09 & 0.71 & -0.60 & -0.54 & 0.31 & 0.60 & -0.43 & -0.31 \\
\hline Darters + madtoms + sculpins (richness) & 0.06 & -0.23 & -0.23 & -0.12 & -0.20 & 0.32 & 0.84 & 0.49 & -0.55 & 0.23 & -0.03 & 0.23 & -0.46 & -0.38 \\
\hline Top carnivores & 0.14 & -0.43 & 0.71 & 0.49 & -0.89 & 0.20 & 0.31 & 0.71 & -0.54 & -0.71 & -0.09 & 0.26 & -0.43 & -0.37 \\
\hline GSFYBHBGCC & 0.14 & 0.14 & -0.71 & -0.03 & 0.37 & -0.60 & -0.37 & -0.71 & 0.49 & 0.71 & 0.26 & -0.20 & 0.14 & -0.03 \\
\hline Algivores + detritivores & -0.54 & 0.43 & 0.60 & 0.49 & -0.26 & -0.54 & -0.49 & -0.31 & 0.37 & -0.60 & -0.49 & -0.20 & 0.14 & 0.31 \\
\hline Darters + madtoms + sculpins & -0.09 & 0.26 & -0.20 & -0.77 & 0.89 & -0.09 & -0.60 & -0.31 & 0.26 & 0.20 & 0.20 & 0.14 & 0.31 & 0.43 \\
\hline Green sunfish (includes hybrids) & 0.14 & -0.03 & -0.43 & 0.49 & -0.26 & 0.03 & 0.37 & -0.26 & 0.20 & 0.43 & -0.03 & -0.43 & 0.09 & -0.20 \\
\hline Invertivores & 0.43 & -0.37 & 0.26 & -0.09 & -0.09 & 0.20 & -0.31 & 0.26 & -0.14 & -0.26 & 0.37 & 0.20 & 0.03 & -0.09 \\
\hline Centrarchidae & 0.60 & -0.37 & -0.43 & -0.09 & 0.09 & 0.03 & -0.14 & -0.09 & 0.03 & 0.43 & 0.54 & 0.03 & 0.03 & -0.26 \\
\hline
\end{tabular}


Publishing support provided by Lafayette Publishing Service Center 

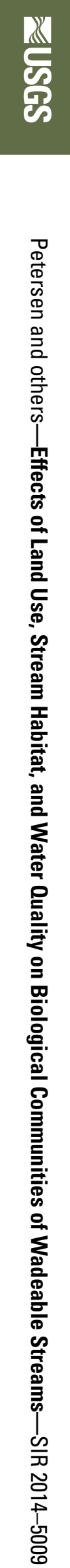